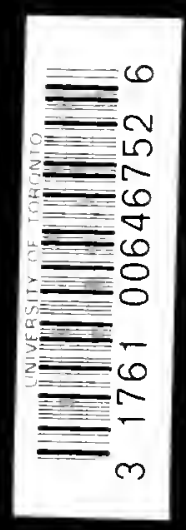


Digitized by the Internet Archive in 2007 with funding from Microsoft Corporation

http://www.archive.org/details/reportonethnolog00hilluoft 


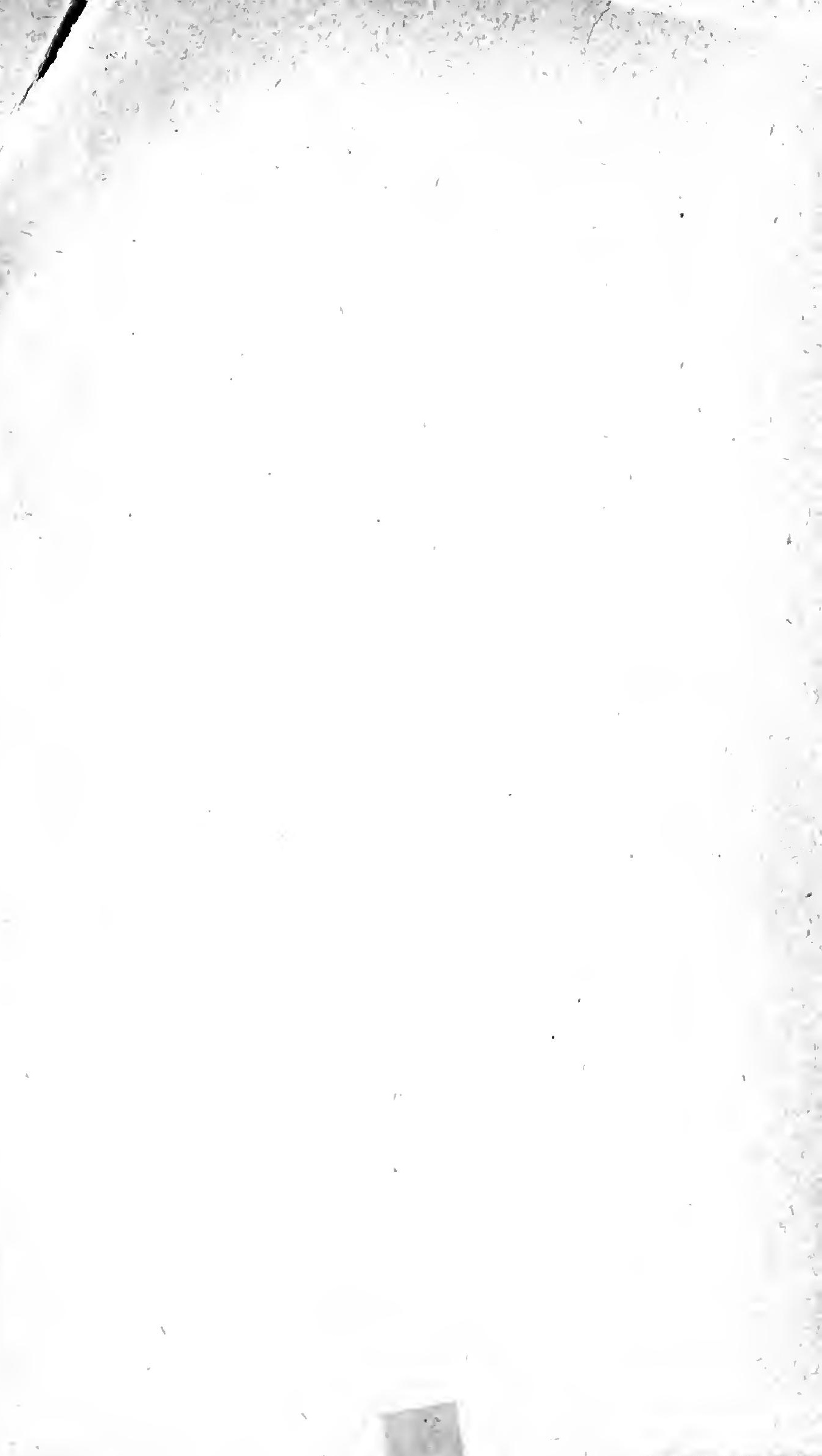



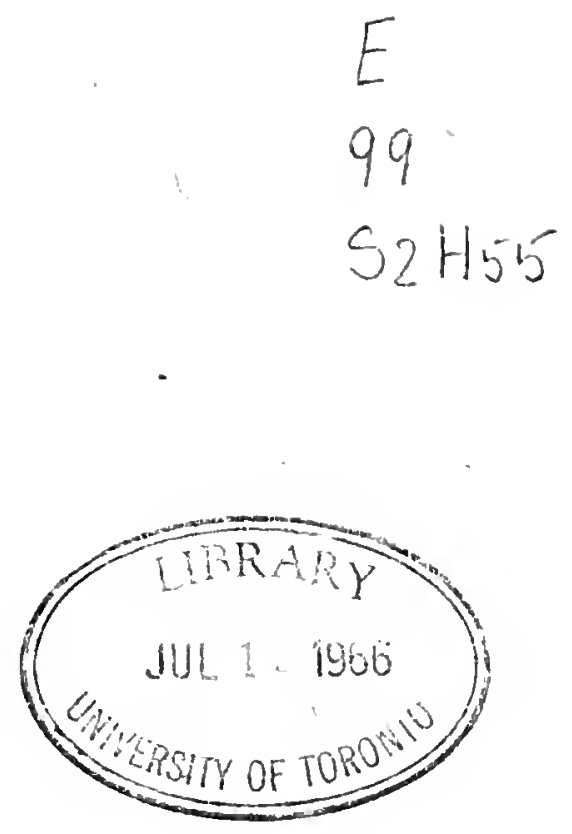

1096455 

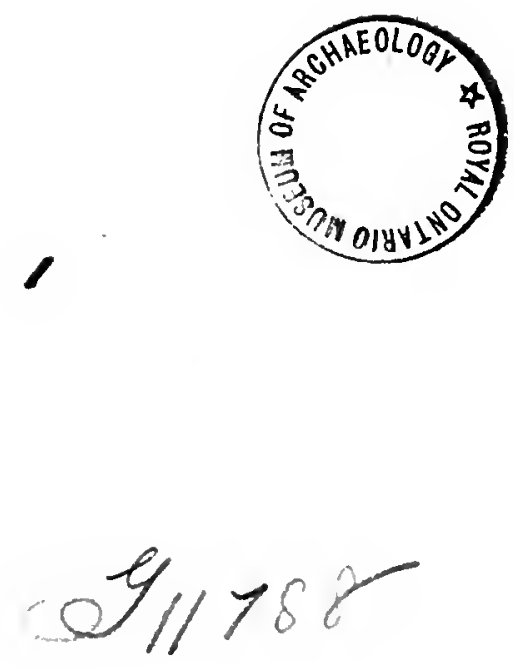

REPORT ON THE ETHNOLOGY OF THE SOUTH-EASTERN TRIBES OF VANCOUVER ISLAND, BRITISH COLUMBIA.

By C. HILL Tout.

Local Correspondent of the Royal Anthropological Institute. 


\title{
REPORT ON THE ETHNOLOGY OF THE SOUTH-EASTERN TRIBES OF VANCOUVER ISLAND, BRITISH COLUMBIA.
}

\author{
By C. Hill Tout,
}

Local Correspondent of the Royal Anthropological Institute.

THIS paper contains a summary of my strdies of the Salish tribes of the south-eastern portion of Vancouver Island, known to us under the name of LEkúñEn, with additional notes on the neighbouring Cowitchin or Island Halkōmélem tribes.

I have again to acknowledge my indebtedness to the Government Grant

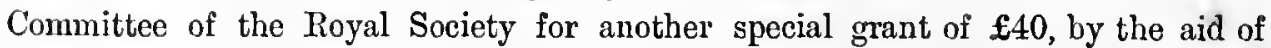
which I was enabled to cover a larger field of inquiry and make a closer examination of the ethnology of this section of the province than I could otherwise have accomplished.

The LEkíñen, together with the cognate tribes of the Saanich, the Clallam, and the Sooke, form a division apart from the rest of the Salish of British Columbia, and belong rather to that portion of the Stock whose habitat lies immediately to the south of the International Boundary; and just as the various Cowitchin tribes speak of themselves collectively as the Halkōmélem, or "speakers of the same language," so do the tribes of this division call themselves by the term LEk oñếnEñ, which meaus the same thing. By this convenient term I shall hereafter call them when spcaking of them collectively. In their social organisation and in their language they have, as will be seen, many interesting features peculiar to themselves.

As I came in contact with the Cowitchin or Island Halkōmélem tribes, I took occasion to learn, for the sake of comparison with the mainland tribes of this division, something of the traditions and language of this group. Some of the results of this study will be found herein incorporated.

The natives from whom I received most assistance in my studies of the LEkúñEn, are Willian Jack Qámetcten, a lineal descendant of the old chiefs; Sinoppen, the chief of the Esquimalt Band; and the wife of Thomas James, my chief informant on the Cowitchin, the husband and wife being of different tribes.

I fear the study of these tribes has bcen delayed too long to obtain the best results; all the older people, versed in the knowledge and ways of the old days, have passed away, taking with them much valuable information that will now be lost to us for ever. 
I have recorded here all that a diligent care enabled me to gather concerning the past of the Lekuñ̃n. Their eomparatively long contact with the whites, who settled in their midst more than a half century ago, has much modified their lives and customs; and the present generation knows but little of the life and conditions of its forefathers. They are by no means the best representatives of their race; indeed, of all the Salish tribes of British Columbia, I fear they have benefited least by contact with a superior civilisation. Alcoholism and all that follows in its train have wrought sad havoc among them both physically and morally. Tonching the former, their mortality has been appalling. From a strong and populous community of 8,500 souls in 1859 , they have dwindled down now to about 200, or less than one-fortieth of their former number. They appear doomed to speedy extinction. In the seventeen years whieh have elapsed since Dr. F. Boas made his first reconnaissance of the Island Salish, many changes have taken place, especially among the Lekúñen. Upon nany points on which he was able to gather information, I could learn nothing at all, those who might have supplied the information having all passed away. My notes in some points are not quite in agreement with his, particularly as to the local divisions of the LEkúñEn; but in the main the information gathered in 1905 harmonises with that gathered in 1888-9, such differences as exist being such as might, in the circumstances, be expected to occur.

\section{EThNOGRAPHY AND SOCIOLOGY.}

According to my informants, the LEkúñEn occupied the following villages before the advent of the whites and the founding of Victoria by Governor Douglas :-
$\left.\begin{array}{l}\text { 1. S'ñéka } \\ \text { 2. Sluk'u }\end{array}\right\}$ Caulboro' Bay.
3. Tcíkñīn, Shoal Bay.
4. Qsāpsem, On the Gorgc.
5. Sk'uñínEs, Discovery Island, off Oal:
Bay.
6. Tcīakaúitc, Around Ross Bay.
7. Soñes, Near Parry Bay.
8. Nukstlaiyum
$\left.\begin{array}{l}\text { 9. Tcî́nuk } \\ \text { 10. Tcīwếtsun }\end{array}\right\}$ Beecher Bay.
11. Sqēmätlitl, Esquimalt Harbour.

After the founding of Victoria, first called Camósun, after the Indian name of the "rapids" on the Gorge, the natives flocked into the harbour in great numbers and settled at what is now the foot of Johnston Street. They were known as the Swiñhon, and were composed of members of the various outside villages. This became a populous centre, so populous, indeed, as to inconvenience the colonists; and Governor Douglas induced them to cross the bay and scttle on the other side, where there has been a mixe'd settlement ever since, known as the "Songish Reserve." He also transplanted the village of the Qsâpsem, who dwelt near the spot where the Parliament Buildings now stand, to Esquimalt Harbour where a remnant of the tribe still lives.

Dr. F. Boas classified the various divisions of the Lekniñm as "gentes," but 
I prefer to regard them as septs. I can see no difference between the sub-division of the Island tribes and those of the Delta tribes. This word gentes lad a very loose meaning in this country at the time when Dr. Boas wrote, and I am not sure what he meant to convey by it. Each local group or sept looks upon itself as distinct from the rest, and believes it had a separate origin. Each claims to be descended from a certain "first-man," but yet the individual members of the local group do not all regard themselves as akin to one another, as they should if the local group were a true gens. At uny rate, if the sub-divisions of the LekúñEn are gentes, then so are also the sub-divisions of the Delta tribes, for they also claim descent equally from "first men" in the same way. The only difference I can perceive between the sub-divisions of the LEkúñen and those of the Halkōmélem, or the Síciatl or the Skqoómic, is that the first have separate and exclusive fishing, hunting, root and berry-grounds, and the others have not. But this feature of the sociology of the Lekuninen I regard as the result of their peculiar social organisation and not as evidence of their division into gentes.

Each local community is, or was, composed of distinct classes or castes. First comes the caste of the chieftains, the office of Headman being strictly hereditary among the Lekúñn; second, the caste of the hereditary nobility; third, the caste of the untitled or Base-Folk; and fourth, that of the slaves. The lines of demarcation between these several classes were hard and rigid, and could not be broken except perhaps in the case of the last two. Orphaned and friendless children were sometimes pressed into servitude and thus passed into the slave class.

The sons and daughters of chiefs customarily intermarried only with those of their own caste, and thus a " princely" class was maintained. In like manner nobles married only with nobles, and no amount of wealth in an untitled person could raise him to the ranks of the hereditary nobility. This is brought out in a very interesting manner by the creation of an intermediate class which formed a kind of bourgcoisie. This class was distinguished from that from which it sprang by a name of its own. This, in the Lekúñen, was Nitenánit, and the term had literally the same significance in the mind of the Indians as the word parvenu had in the minds of the French under the old régime. The Nitcnánit were men who, by their ability or good luck, had acquired wealth, by means of which in giving feasts and potlatches, they had gained a certain social standing in their tribe, but as they had no "grandfathers," no pedigrees of honourable descent, and no family or kin-crests, they could not be admitted among the hereditary nobles, and so had to form a sub-class intermediate between these and the common folk.

The cxclusiveness of the privileged classes is illustrated in all their social functions. On these occasions the chiefs put on lofty and condescending airs, conversed only with one another, and always formed a group apart from the others. The hereditary nobles formed a similar second group, and the untitled or common-folk, a third. The Nitcnanit or nouveaux riches held on these occasions a rather equivocal position, determined largely by the condescension of the nobles and the degree of respect and consideration paid them by the people. 
The LEkúñEn method of receiving and placing their guests was absurdly like that in vogue in high social functions among more sophisticated peoples. Two or more of the older noblemen stood at the entrance of the Feast Chamber and received the visitors, inquiring their names or titles and those of their fathers and grandfathers, and placing them aceordingly-rank being determined and marked by these as distinetly as among ourselves. Each social division or caste had its own list of names or titles, so that a person had but to give his name or that of his father or grandfather to show his social position and standing in his tribe.

Among the LEkúñEn, titular names were bestowed upon their bearers only when they had reached and passed the age of puberty. This was done in a very formal manner among the nobles.

When a father wishes to bestow one of the family names upon his son it is customary for him to do it in the following manner: he first visits the chief of his commune and informs him of his desire and seeures his consent and promise of assistance. A date is then fixed for the event, and invitations are sent, broadeast throughout the neighbouring tribes. The day appointed having arrived, his guests come in from the various villages round about. In the meantime he has been making great preparations to receive and entertain them. Large quantities of food have been bronght together by his family and kinsfolk; the family treasure-ehests have been opened and their contents set in order for distribution at the feast. When all is ready for the ceremony the father takes his son, accompanied by the latter's sponsors, to the roof of the family dwelling-the piteh of whicl is exeeedingly shallow and convenient for the purpose-and from this vantage ground the proceedings take place. These vary to some extent from centre to eentre, and from district to district, but, commonly, the eeremony is opened by the father of the boy daneing and singing one of the family dance-songs. This song-danee is usually a more or less dramatic representation of some event, real or faneied, in the life or history of his aneestors, probably that which gave rise to the name he is going to bestow upon his son. When the dance is over a distribution of blankets or other gifts is marle to honour the names of the spirits of the family, it being held to be dishonourable to speak of or even mention an ancestral name publicly without making gifts. Formerly, these gifts were always blankets, now other artieles are often given. The father next calls about him some thirty or forty of the leading noblemen among his guests to act.as sponsors or witnesses of the rank his son will aequire through the name he is about to receive. Two elder men, or, preferably, two aged chiefs, who know his lineage and aneestry, now bring the youth forward, and, standing one on either side of him, the elder of the two proclaims in a loud voice to the assembled andienee that it is the wish and intention of the boy's father to bestow upon him his paternal grandfather's name or title. At this announeement those present express their assent and pleasure by elapping of hands and shouting.

The name or title is then given to the youth, and another distribution of blankets takes place, special care being taken to give at least one each to all the 
formal witnesses of the ceremony and to the officiating elders. If the father of the youth be a man of wealth he will now throw other blankets among the common, untitled folk to be scrambled for, amid much excitement and fun. When this part of the cercmony is over the feasting begins.

After the ceremony is over the youth is known by his newly-aequired name, though, according to the universal custom among the Salish, he is never or rarely called by it except on special and ceremonial occasions.

Among the Lkkúñen and cognate tribes a man could not take his own father's name, even though his father be dead, the names of deceased persons being tabooed among them for a whole generntion. All the ancestral names were thus lianded down in these tribes.

In connection with names, I may here say that although I did not learn anything new concerning them, I received everywhere confirmation of the statements respecting their general significance, made by "Captain Paul" as recorded in my last report. ${ }^{\mathrm{I}}$

In their marriage customs the LEkúñEn differed in some interesting features from the other tribes examined, and the ceremony brings out in a very distinct manner the pride and exclusiveness of the nobles.

Among men of rank, marriage was, and to some extent still is, a very formal ceremonial affair, and the young people themselves were never permitted to choose their own mates. When a youth has arrived at marriageable age, the elders of his family look around them for a suitable bride for lim, and his wishes are rarely, if ever, consulted in the matter.

When they have chosen a girl they think desirable, negotiations are opened with her parents and family. This is done by several of the suitor's (Eckwásiñ) clder-women paying them a formal visit and diplomatically sounding them on the subject of the marriage. If the suggestion of an alliance is not favourably received, the matter drops at once, and no more is said upon it. If, lowever, it is favourably received, no further progress can be made at this stage, the offiee of the elder-women being merely to open up the negotiations. The next step in the proceedings is taken by the Ecinán, that is, the elder-men, whose duty it is to set forth the pedigree and honourable descent of the suitor.

These men now pay the girl's parents a visit, and make known to the family their young kinsman's rank and standing. Should the girl's relatives be satisfied on these points, a day is then fixed for the Eckwâsin to come for his bride.

When the time for the ceremony of fetching the bride comes round, the family and friends of the kckwásiñ's party set off in their canoes for the camp or settlement of the bride's father: They have, of course, been cxpected, and preparations have been made to receive and entertain them. They take with them the ctcEtlallwwotQ, or "bride's price," which the relatives and friends of the groom's father have assisted him in getting together. When tlıc party arrives the bride's father immediately 
shuts and secures the door of his dwelling, round about which a large crowd has assembled. The groom's father now calls out to some half-dozen of the more socially prominent of those present and requests them to ask to have the door opened, that his son may seek his bride. They are encouraged in their service by gifts of blankets. 'These men now knock at the door, and beg the bride's father to open his door to his prospective son-in-law. For a long time he refuses to do this, but when this singular feature of the ceremony is over and the door is at length thrown open, these. same men go down to the water's edge and lift the canoe containing the bridegroom and ctcEtlälkwote bodily out of the water and convey it into the house of the bride's father. Here it is set down with the youth still in it, and he is now supposed to remain there until his bride is bronght and placed beside him. This may not be for two or three days; the higher his social rank, however, the shorter the time of waiting. When the time of probation is over, the bride's father calls two elder-women of his family to him and bids them take the luride to the groom. This they do, and place her in the canoe with him. He then instructs them to place food before the youth. A large quantity of food is then placed before the young man, who eats a little and sends the rest to his friends, who have been waiting ontside. This is the central feature of the ceremony, and the girl is now his wife. Those present in the house clap their hands and shout their approval of the proceedings. The groom now presents the "bride-price" to the girl's father, who shares it with his friends. These in return now make presents to the bride, and shortly after the canoe is carried back to the water, and the gathering breaks up, and the visitors return to their own village. This closes the first part of the marriage ceremony. Before, however, the ceremony is complete, a return visit has to be paid by the bride's family and friends. This usually takes place about one moon after the return of the groom to his own village. He is busy during this period making preparation for the reception of his fathor-in-law. The latter comes in due time laden with gifts of food and blankets. Onc side of the dwelling is given over to the visitors, the regular inmates occupying the other. All the friends of the groom have been invited for the occasion, and a great feast has been prepared.

When all is ready and the guests all present, the groom rises in his place and says to his own friends, "Before you may eat this food, so generously provided by my father-in-law, I must pay for it." "That is right and proper," respond they, "ouly'don't delay, for we are hungry and wishful to begin." With this the groom turns to his father-in-law and publicly thanks him for his gifts. "But," says he, "I cannot accept them without making a return to you." He then counts the presents of his father-in-law and sets a generous value upon them. He now makes a return in kind, of equal or greater value, which the father-in-law accepts. When this is done he says again to his father-in-law, "I am still in your debt; I owe something to the canoes by which you brought me your present. The sails of the canoes werc very serviceable; pray take five dollars on account of each sail. The bailing cups, too, were useful, for without them the food would have beon injured. 
Here are two dollars each for the bailing-cups. The paddles, too, inust not be forgotten; withont them you could not have got herc. 'Take one dollar each for' the paddles. For the canoes themselves I ask your acceptance of tiventy dollars each, and for the paddlers five dollars each.

"Now, I would like to make you a present yourself. You are now my fatherin-law, and it is fitting for your daughter's husband to remenber her father. Here is one hundred dollars; pray take them for yourself and this hundred for your wife."

This generous distribution of money or its equivalent has been much appreciated by the recipients of the presents, and has also given great satisfaction to the groom's friends. His position as a great man is well assured from this time onward. The distribution of presents over, the feasting now begins. This is customarily kept up, accompanied with games and dancing, for several days. The longer the period the greater the event and the higher the honour and social prestige of the groom.

Of the other social customs of the LEk'onén Eñ I was able to gather little of interest, so complete has been the disintegration along these lines. The old-time "secret societies" have apparently wholly passed away, and I conld learn nothing reliable concerning them. In their dwellings, dress, and food, the Lak 'oñénen closely resembled the Delta Salish and their Cowitchin neighbours.

\section{LiNGUISTICS.}

As far as I am aware, no attempt has been made to set forth the grammatical structure or dialectical peculiarities of the Lekúñn speech. Though having a few features in common with the neighbouring Halkōmélem, it belongs to a totally different linguistic group. Apart from the cognate tribes, the Saanich, the Clallam and the Sooke, its affinities link it with the Salish tribes of the opposite shores of North Washington rather than with any others in British Columbia. It may be said to form with the Clallam and the Lummi of Puget Sonnd, a distinct sub-linguistic group called by the Sungish about Victoria the Lek oñenEñ speech; the term signifyiug in Lekúñen what "Halkōmélkm" does in the Stálō or Fraser River speech-" one and the same language."

Its most noticeable feature in comparison with the other British Columbian Salish dialects is a strongly nasalised $\tilde{n}$. It has a feature also in common with the StlatlumH presented in my last report. ${ }^{1}$ Many of its verbs end in $n$, only as a rule they are here nasalised. This $n$ is the equivalent of the commoner $m$ of the other dialects. Throughont the vocabulary $n$ nasalised or otherwise, replaces the $m$ of the Halkōmélem; thus :-

\section{- Lak'oñénFñ.}

alnũ, house; hásEñ, to sneeze ;

su'ña, lettle; sépteñ, to tickle;

stéloñ, song; sákōñ, to urush oneself.

\section{Halkōmêlem.}

lält:m, house; lläsem, to sneeze ;

'súma, kettle; sếtEm, to tiekle;

stếlFin, song; SúQFm, to vash oneself.

Other exanples may be seen in the vocabulary. 
Another peculiarity is the use of the particle $k \bar{o}$ in verbal constructions. It corresponds to the $p a$ of the Island Halkōmélem, and like it, though it may sometimes have a definite meaning and force, may often be left out without apparently affecting in any way the sense of the plirase or sentence. Numerous cxamples of its use are given below in the native texts.

The indeterminate character of the vowels is as marked in Lkk'onénEñ as in the other dialects examined. This applies equally to long and short vowels.

\section{Phonologi.}

Vowels.

\begin{tabular}{|c|c|c|c|}
\hline \multicolumn{4}{|c|}{ a, as in English hat. } \\
\hline$\overline{\mathbf{a}}$ & , & ” & father. \\
\hline 凡̂ & " & ", & all. \\
\hline$\ddot{a}$ & $"$ & $"$ & gnat. \\
\hline$\theta$ & " & ” & pen. \\
\hline$\overline{\mathrm{e}}$ & $"$ &, & they \\
\hline
\end{tabular}

$$
\begin{aligned}
& \text { i, as in English pin. } \\
& \text { i " " pique. } \\
& \text { o " " pond. } \\
& \text { o " , tone. } \\
& \text { u " , but. } \\
& \overline{\text { u }, ~ " ~ b o o t . ~}
\end{aligned}
$$

E, obscure vowel as in English flower; "written above the line, a vowel sound which sometimes follows the palatised $\mathrm{k}^{\cdot}$ aud is only partially articulated.

\section{Diphthongs.}

ai, as in aisle; au, as in cow; oi, as in boil.

\section{Consonants.}

$\mathrm{h}$, as in English.

$\mathrm{k}$,

$\mathrm{k}$, a strongly palatised .or "clicked" $k$.

$\mathrm{k}$, intermediate between our $k$ and $g$.

tl, an explosive palatised $l$.

1, as in English mostly, but interchanging with $n$ in the moutls of some speakers.

$\mathrm{m}$, as in English.

n " ,

$\check{n}$, a strongly nasalised $n$, equal to $n g$.

$p$ as in English.

p', no equivalent in English, a kind of semi-mute, semi-sonant.

8, as in English.

$\begin{array}{ll}\mathrm{t}, " & \\ \mathrm{w}, & \end{array}$

$\mathrm{q}$, as in $c h$ in loch in broad Scotch.

Q, approximately as $w h$ is uttered in North Britain. 
I, as in the German ich.

c, as in English $s h$.

te, as $e h$ in the word elureh.

ts, as in English.

$\mathrm{kw}$, as $q u$ in the word quantity.

The comma sign' written above the line, indicates a panse or hiatus usually cansed by the elision of a vowel. When placed at the end of a word it indicates that the final letter is nttered with stress.

\section{Accent.}

Acent in Lkkononfun appears to follow the same laws as in the other Salish dialects examined.

\section{Number.}

Nunber in Lek'oñénEñ is distinguished by rednplication, epenthesis or diæresis. This rule applies equally to nouns, adjectives and substantive verbs. Thns :-

\begin{tabular}{|c|c|}
\hline sméyis, a decr. & smEmēgis, decr. \\
\hline skăqaa, a dog. & skaláqa, dogs. \\
\hline ckwón, a panther. & ckwklóa, panther's. \\
\hline cépan, a knife. & celêpen, knives. \\
\hline ck'wum, an axe. & ckwÉlkwīkwum, axes. \\
\hline stēkêū, a horse. & stalakéū, horses. \\
\hline sũáñyit, a stone. & slìláñyit, stones. \\
\hline k’áñi, maiden. & k’alânĩi, maidens \\
\hline swéEka, man. & sōwēEka, men. \\
\hline kElếna (one), dirty. & kEkbléma (several). \\
\hline kw'stlalóq (one) old. & kw'stlilalōq (several). \\
\hline kqatl-sEn, $I$ am sich. & Esqulqatl-tlta, we are siek. \\
\hline
\end{tabular}

\section{Diminutives.}

linife, cépan.
axe, ck·wiun.
horse, stēkéū.
stone, sñañjit.
deer, smēyis.
doy, skína.
panther, ckwōa.

linife, cépan.

axe, ek'linul.

horse, stèkéū.

deer, smēyis.

doy, sḳíqa.

panther, ckwōa.
deer
skalấqa, dogs.
ckweloa, panther's.
ckwélkwīkwum, axes.
stalakêū, horses.
sōwēeka, men.
(several).
Esqulqatl-tlta, we are siek.

\section{Gender.}

We find a grammatical gender of a kind in LEk onéneñ as in some of the other Salish dialects. It is confined to certain demonstratives, particularly those used to indicate the third person. thrs, tsiia, that, he, and sii, that, she. Again, in the 
possessive pronouns when compounded with demonstrative particles, a similar distinction is made; but it must be clearly understood that no genderal distinction is made in the pronoun proper, only in the locative or demonstrative particles attached to it, for when these are absent so is the genderal distinction.

\section{Personal Pronouns.}

Of these we find the usual three classes, viz., the Independent, the Copulative or Enclitic, and the Incorporative.

\section{Independent Pronouns.}

$I$, me, úsa. thou, thee, núkwa. he, tsáa. she, sä. $w e, u s$, thñiñetl. you, nukwélia. they $\left\{\begin{array}{l}\text { tsåa } \bar{o} \\ \text { sï } \bar{o}\end{array}\right\}$ nenétlia.

This is the common form. A Selective or emphatic form is used at times. This differs from the cornmon form by having the denonstrative particle " tía " added to it, thus : tía úsa tía, tlñiñetl, ete.

\section{Copulative Pronouns.}

$$
\begin{aligned}
& I \text {, -sEu. } \\
& \text { we, -tlta. } \\
& \text { thou, -sōy-teē or teī. } \\
& \text { you, -sōohăla, teèhála. }
\end{aligned}
$$

These are the common forms used in direct statements; the eonditional forms are somewhat different as may be seen from a study of the verhs. The secondary forns in the second person are those commonly employed with transitive verbs, -sōe being the common form for substantive verbs.

\section{Ineorporative Pronouns.}

I will help you, kwEnáñ EsEn sä. $" \quad$ " him, ō kwEnáñ EsEn sä tsaın mittl.

Thou wilt holp me, kwEnấñesQ sï.

" " " him, kwlúiñet tsau nítl.

We will help him, ō EtlñiñEtl sä kwenáñet tsau nítl.
" " thee, , ,
"kwEnáñEse.
" "you, " " " $\mathrm{kwEnáñEsshála.}$

He will help me, tsau nītl sä kwEnáñes.

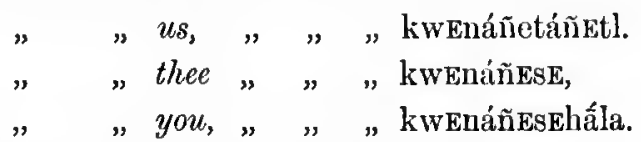

They will help me, ō nEnētlia sä kwenéñ Es

$$
\begin{aligned}
& \text { " " thee, " " kwEnéñ EsE. } \\
& \text { " "you, " " kwenéñusshála. }
\end{aligned}
$$


You will help us, kwEndiñetañetl-sōQ-hấla.

You had better help us, êi EnasusQ-hala kwEnañetañetl.

I see thee, ō k'WFn-'sī-sEn.

$m e$, ēnalia sta kwEnañes.

"you, ô k'wEn-sī-sEn-hüla.

" them, ō k.wEn-èt-sEn tsau nenētlia.

„ him, ö k•wEn-ēt-sEn tsau nītl.

Thou scest me, ō k'wen noñususQ, or, $\mathrm{k} \cdot \mathrm{w}$ enếsusQ.

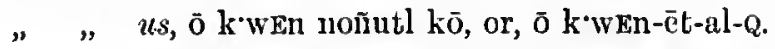

" " him, ō k'wen-ētesQ kō, or, k'wenōe kwEsQ.

You saw me, ō ye-k'wenēsq hāla, or, ō ye k’wen èsesq hála.

You see me, ō k'wen noñus kō hâla.

" " us, ō wē k'wEnētañutlusQ.

You saw us coming, ō ye k'wenētalaqusq.

" "them " $\overline{\mathrm{o}} \mathrm{k}$ 'wenètsq kō tsau nenētlia.

We see you, ō wē k'wEn nōtlta.

" „ him, " " nētlta tsau nītl.

" "them, " " " nEnētlia.

He sees us, ō wē k’wEnteñtlta kō, or, ō yE k'wenteñtlta.

" "me, ō k•wenáñus kō.

" "you, kwtl k'wentañes kō.

" " thee, kwtl k'wrnoñsQ kō.

I like thee, nE-stlē-sōQ.

" you, nE-stlē-sōQEn Ekwélia.

We like thee, stlē-tltas kō(E)núkwa.

" " him, stlē-tlta kō tsau nītl.

" " you, stlē-tlta núkwélia.

" "them, " "n Enétlia.

Thou likiest me, núkwa stlē tẻ usa.

Thou lilest us, uníkwa stlē tīa Etlñiñ Etl.

" " him, " stlès tsau nitl.

It will be seen that in the latter verb " to like," little, if any, incorporation of the pronoun takes place. It will also be observed how different the ineorporative forms in this dialeet are from those in the dialects examined before.

\section{Possessive Pronouns.}

Of these, there are two forms, the General and the Selective, thus :General Form.

my father, ne-man.

thy " un(E)man.

lis "man-s.

our " man-tlta.

your " un matı-hála. 


\section{Selective Form.}

my father, tīa nk man.
thy " $\quad$ tên (a) man.
his " tsäa mans.
our " tīa man-tlta.
youv " ten (a) man-hála.

Locative Possessive Forms.

These differ from the simple possessives by having a locative particle added to them. These particles have a formal gender, and thus distinguish between masculine and feminine objects, thus:-

Object present and visible.

Masculine' Form.

my doy, tīa ne-skéq́a.

thy " tīa un-skiqua.

his " tia sḳáqas.

Feminine Form.

my dog, sīa nE-sḳáqa.

thy " sia un-sḳáqa.

his " sīa skáqas.

Object present but invisible to spectier.

Masculine Form.

my father, kw'īa ne man.

thy " kw'ìa un (a) man.

his ", " mans.

our " „ mantita.

your " " , un (a) man hắla.

Feminine Form.

my mother, kw'sīa nE-tan.

thy " " $\quad$ mn-tan.

his " " tans.

onv " " $"$ tan-tilta.

your " , un-tan-hấla.

Object absent and invisible to spealier.

Masculine Form.

my father, kw'sā ne man.

thy " kw's un (a) man.

our , kw'sc̄ mantlta.

your " kw's en (a) manl laála. 


\section{Feminine Form.}

my mother, tlesā nEtan.

thy " tlisson tan.

our " tlesā tantlta.

your " tleson tan hấla.

\section{Substantive Possessive Pronouns}

mine, naskwa.

thine, unskwa.

$h i s$, skwas. ours, skwatlta.

yours, unskwa hâla.

their, skwas tsau nenétlia.

It or this is mine, neskwa tla.

" " thine, unskwa tla.

" " ours, tla skwatlta.

" " yours, tla unskwa hála.

This is mine, netl neskwa tla.

" thine, netl unskwa tla.

These substantive forms are occasionally used with the object to enphasise the ownership, thus:-

This is my house, netl ō neskwa álañ.

\section{Reflexive Pronouns. \\ self, kwónetūq.}

Indefinite Pronouns.

anybody, everybody, sánīa.

no-body, aúinasan.

\section{Interrogative Pronouns.}

who? san?

who is that? nitl yuquatce san?

who are you? núkwa san?

who did or made that? tīq san

átcis tcē ?

what's that? stañ átce ?

whose? tinq san? whose is that? tūq san âteE?

whose house is that? tūq san âtce áleñ ? what? stañ?

what do you want? stañ kwEn's stlē ? or, stañ átck kw's stlē?

which? tuqēin?

which do you want? tuqếin unstlē?

zohich man? tuqếin swếeka? 


\section{NuMERals.}

Class numerals abound in this dialect, as in the others examined. The simple or absolute forms are as follows:-

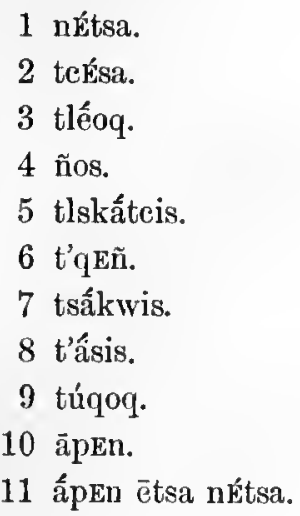

20 tsaúqkwus.

$21 \quad$ c̄tsa nÉtsa.

30 tlaúqcä.

40 nÉsÉtlcï.

50 tlúkutsetlcä.

60 t’EquñEtleï.

70 tsúk *u Etleä.

80 t’ásisetlcä.

90 túqoqetlcä.

100 nä'tcō(w)itc.

1000 āpánite.

\section{Class Numerals.}

Persons.
1 nấtsa.
2 tcäsá.
3 tleqấla.

4 ñ Esála.

5 tlkutc'íla.

10 upEnála.

6 t'quñála.

\begin{tabular}{|c|c|c|c|}
\hline & Canoes, slips, ete. & $\begin{array}{c}\text { Long round things, as } \\
\text { poles, etc. }\end{array}$ & $\begin{array}{c}\text { Round thines, as stones, } \\
\text { money, etc. }\end{array}$ \\
\hline \multirow[t]{2}{*}{$\begin{array}{r}1 \\
2 \\
3 \\
4 \\
5 \\
10\end{array}$} & $\begin{array}{l}\text { nEtsákwetl. } \\
\text { sEñäkwetl. } \\
\text { è tlếtloq. } \\
\bar{e} \text { nóñus. } \\
\text { è tlákais. } \\
\text { e ắpEn. }\end{array}$ & $\begin{array}{l}\text { snEtsanits. } \\
\text { e'ts'anits. } \\
\text { stlōqanits. } \\
\text { sñisamits. } \\
\text { sepEnamits. }\end{array}$ & $\begin{array}{l}\text { netsák kwituo. } \\
\text { tcesálititoq. } \\
\text { tleqấlitoq. } \\
\text { ñEsálitoq. } \\
\text { apenálitoo. }\end{array}$ \\
\hline & Mats. & Houses. & Trees. \\
\hline $\begin{array}{r}1 \\
2 \\
3 \\
5 \\
10\end{array}$ & $\begin{array}{l}\text { netsá́wok. } \\
\text { tcesấwok. } \\
\text { tloq(w)ấwok. } \\
\text { tlukutcsāwok. } \\
\text { EpEnáwok. }\end{array}$ & $\begin{array}{l}\text { netsaútoQ. } \\
\text { súñtoQ. } \\
\text { tléoqutoQ. } \\
\text { EpanốtoQ. }\end{array}$ & $\begin{array}{l}\text { snetcéetltc. } \\
\text { tc'sétetlte. } \\
\qquad-\overline{-} \\
\text { sEpénéEtltc. }\end{array}$ \\
\hline
\end{tabular}




\section{l'artitive Numerals.}

half, utl teuq.

\section{Distributives.}

one cach, netsätōo.

two " tcesatūo. threc each, tlēoqtuQ.

- four ", ñostūQ.

ten each, äpEntūQ.

\section{Ordinals.}

first, è tltciílat.

sccond, è yistäsEtl. thirl, or middle, or inside, ē stiisetl. last, $\overline{\mathrm{e}}$ tlkwấwas.

It is interesting to note that the particle $\overline{\mathrm{c}}$ is in this dialect employed with ordinals and also with some of the class numerals, such as canoes, ships, etc. In the Stlatlumi dialect we find it entering into the formation of the Distributives. The nse of identical particles or terms in different ways is one of the most interesting features of the Salish language. While revealing the common origin and unity of the various dialects, notwithstanding their general diversity of form and structure, it shows also the plastic informal condition the language must have been in before these dialects arose.

\section{Auverbial Numerals.}

once, netsaúq. twice, suñsañ. thrice, tleq(w)átl. four times, ñ Esấtl.

ten times, apknátl.

\section{VERBs.}

The method of inflecting the Verb in LEk onéneñ is the same as that observed in the other Salish dialeets examined. A regular past is formed by adding $l \bar{a}$ to the present stem, usually between the stem and the pronominal element. This $l \bar{a}$ is probably the $n \bar{e}$ or $\bar{l} \bar{e}$ of the Halkōmélem dialects. The simple future is formed by adding to the verb stem the particle $s \ddot{a}$. This also is probably a modified form of the $t s a$ or $t c a$, the future particle of the Halkomélem dialects. This similarity is noteworthy. It is the first time that we have found the signs for the "future" alike in any two of the lialects; heretofore we have met with a different form in each dialect examined, and that in dialects more closely related to one another than. is the LEk:onéneñ with the Halkōnélem. 


\section{Subs'intive Verli.}

Prescut Tense.

sicli, Esqútlatl.

I am sick, Esqátlatl-sEn.

thou art sick, Esqátlatl-sōQ.

he is siek, Esqútlatl tsáa.

she " we are sick, $\left\{\begin{array}{l}\text { Esqulqátl(E)-tlta. } \\ \text { Esqátlatl-tlta. }\end{array}\right.$
you ", $\left\{\begin{array}{l}\text { Esqulqátl-sōo hálla } \\ \text { Esqátlatl ,", }\end{array}\right.$

they are siel, Esqútlatl tsau nenítlia.

Aorist.

I was sick, Esqátlatl-lā-sEn.

we were sich, Esqulqátl-lä-tlta.

thou wast sick, Esqaitlatl-lā sōe.

we were sick, Esqátlatl-lì-tlta.

you " " esquatlatl-lī-sōe-hăla.

" " " Esqulqatl-lāisōe-hálin.

The plural forms are optional; the speaker uses either, though the Esqulqatl form is the more idionatic. In the Sooke dialeet the singular form is always "Esqatl." The duplication here scen secms to be peeuliar to the Lekíñ En.

There is a seeondary past whieh answers pretty nearly to our "periect past," thus :-

I have been sick, klā-lä-sEn-sqútlatl.

thou hast been siek, klā-lī-sōę-sqátlati.

we have been sick, klā-lī-tlta-sqátlatl, or, ksquulqatl.

you " „ klā-lā-sōe-sqátlatl-hắla, or, Esqulqatl-hấla.

From the native texts given below, it will be seen that the particle $k \bar{o}$ is largely used in verbal construetions. It is difficult to render this into English, as we have no equivalent for it. Its use is idiomatie in the Lek'oñeneñ, and its absenee does not, at least in many instanees, affeet the meaning of the sentenco It answers to the " $p a$ " of the Island Halkōmélem, a particle wholly absent in the Fraser River dialects of this linguistic group.

Future Tense.

I shall be sick, Esqatlatl-sEn sii. thou wilt be sick, ", -soQ sä.

we shall be sich, Esqatlatl-tlta sia. you will " " " sōę-hála sï.

\section{Conditional Forms.}

$I$ think $I$ am going to be siek, Esqatlatl-yūq-sEn-sï. when $I$ am sick, kwEnEs Esqatlatl lā. if I am siek, kwE esqatlatl-En. when thou art sick, kw's En-Esqatlatl lā. 
if thon art sick, kwE Esqatlatl-ōg.

when we are sick, kw's Esqulqatl-tlta lī.

if " " $" \mathrm{kwE} \quad "$

when you", " kw's En-Esqulqatl-lā-lıála.

if " " , kwE Esqulqatl-hála.

\section{Dubitative Forms.}

I macy be sick, éwā kō Esqátlatl-sEn sä. we " " " esqulqatl(E)tlta sä.

\section{Negative Forms.}

I am not sick, aúa-sEn Esqátlatl. we are " aúa-tlta Esqulqatl.

\section{Interrogative Forms and Replics.}

Are you sick? EsqátlatlesōQ?

(Yes) I am sick, Esqátlatl-sEn.

Is he sick? Esqaitlatl-a tsáa?

(Yes) he is sick, Esqqatlatl tsäa or, Esqatlatl kō tsåa.

There is nothing the matter with me, aúEna nEckwenētl.

I am often sick, ōìấs kw'sênen esqátlatl.

N.B.-Iu some of Lek'oñéneñ dialects, the singular form of this word is qatl or sqatl. The form here given is clearly a duplicated one.

I am hungry, kw'tlkwē-sEn.

thon art hungry, kw'tlkwē-EsōQ.

he is " " tía (or, tsita ō nítl.)

we are " " $"$-tlta.

you are " " $\quad$ Esōôhála.

they are " " tsiia ō nEnítlia.

I am tall, tluktatl-sEn kō.

thou art tall, tluk·tatl sōe kī.

we are tall, tlāluk'tatl-tlta kō.

you " nekwélia tlāluk·tatl kō, or, tlāluk·tatl-sōQ-hála kō.

\section{Active Verb.}

It will be seen from the following that the copulative pronoun for this class of verbs has in the second person a totally different form from that used with substantive verbs. 


\section{Present Tense.}

ctcut, strike.

$I$ strike, cteut-sEn.

we strike, ctcut-tlta.

thou strikest, ctcut-tce. you strike, ctcut-tcē-hála.

he, or she strikes, ctcut-Es.

they strike, ctent-Es (tsïiaōnEnítlia).

By adding $k \bar{o}$ to the above, we get the equivalent of the Halkōnetlem i-tsEnkwákwot, I am striking, thus :-

$$
\text { ctent-sEn ko, I am striking. }
$$

By substituting kwa for $k \bar{o}$ we get the equivalent of the ILalkōmélem né-tsFnkwák wot, I struek, thus :-

cteut-sEn kwa, I struel.

Past Tense.

Aorist.

I struek, etcut-lā sEn.

we struck, " tlta.

$I$ was striking, cteut-lă-sEn kō.

we were striking, etcut-là-tlta kō.

By prefixing ō to the above, we get another form, thus :-

$\bar{o}$ ctcut-lä-sEn kō, I was striking.

This forn may be called the Responsive Past. It is that eommonly employed in answering questions.

\section{Future Tense.}

\section{I shall strike, ctcut-sEn sii.}

we shall strike, ctcut-tlta sii.

By adding $\bar{o}$ and kō to the simple future, a secondary form is obtained. It seems to be used only in answer to questions: will you strike it? and may therefore be termed the Responsive Future. All the Salish dialects seem to use forms in reply to questions which differ more or less from those used in direct speech or statement.

\section{Imperative Forms.}

strilie! hẩi-tcē-ctcut!

strike you! ctcut-tcē !

strike now! cótcēcteut!

strike you (plu.)! ctent-tcē-hála !

let me strike it ! tōe úsutōe etcut !

let us strike it now! tōeế ntlñiñEtl tōe ctent!

" " $"$ tōQē utlñiñtlta ctcut! 


\section{Negative Forms.}

I strike not, ana-sen-cteut. thon strikicst not, aúa-sōQ-ctcut. he strikes not, aúa-ctentes. we strike not, aúa-tl ta-cteut. you strike not, aúa-sōo-cutc't'hâla. they strike not, ańa-ctcútes.

Past Indefinite.

I didn't strike it, ańa-sEn-kwa-sēctent. we didn't strike it, aúa-tlta-kwa-sēctcut.

\section{Past Definite.}

I haven't struck it, ana-sEn-sēctcut. we haven't struck it, aúa-tlta-sēctcut.

\section{Future.}

I shall not strike it, aน́a-sEn-sä-ctcut. we shall not strike it, aúa-tlta-sa-ctcut. thou wilt not strike it, aria-sä-sōe-ctcut. you will not strike it, aua-sä-sōQ-hála-ctcut.

Negative Imperative.

don't strike it, aúa-sōQ ctcut' don't strike me, aúa-sōQ cutc's.

\section{Conditional Forms.}

ái $\mathrm{kwE}$ ctcut-En, if I strike.

" " " $\quad-\bar{Q} Q$, if thou strike.

" $\quad-\mathrm{Es}$, if he, she stritie.

" , - $\quad$-tlta, if we strike.

" " -ōhála, if you stritie.

when I strike, kwenEs kw'tl ctcut lī.

when we struck, kw'tl ctcut-lā-tlta-kõ.

when we shall strike, kw'tl ctcut-tltā sä kō.

\section{Desiderative Forms.}

I wish I had struch it, ctcut-yuk-sEn-ala.

I wish we had struek it, etcut-yuk-tlta-ala.

I wish I eonld strike it, nk-stlë kwEnEs ctcut.

I wish we could strike it, nE-stle kw's ctent-tlta. 
Interrogative Forms.

ctcutEs-Eyue? did he hit it?

cteutrs kō, he llid.

ctcutesōe? dirl you hit it?

ctcut sEn kō, I did.

ctcutesōo sii ? will you hit it?

eteut-sEn sii kō, I will.

Iterative Forms.

ō-citcete-sEn, I am repeatedly stiriting it.

ō-citemte-tlta, we are "

o-citctes, he is ",

Responsive Form of Samc.

$\bar{a}$-tla-sen $\overline{0}$ eiteEtc (yes), I am repeatedly striking it.

$\overline{0}$ cite'tc'sōe, keep on striking it.

$\bar{o}$ etcut-el-tlta kō, we struck each other.

aúa-sōe citct', don't striłe it.

ts'weñet è kwāat, please don't strike it.

Passive Voice Forms.

Aceidental Action.

I am struck, citc-noñ-sen.

thou art struck, citc-noñ-sōe.

he is struek, cite-noñ-se tsäa.

she is struek, cite-noñ-sE sa.

Purposive Action.

I um strusk, ctcut-oñ-sEn.

we are struck, cteut-oñ-tlta.

By prefixing ā-tlā to the above, another tense is formed, which may be termed the Immerliate Past. Thus :

ā-tlā-sEn citc noñ, $I$ am struck.

$\bar{i}$-tlii-tlta citc non, wo are stmuek.

Past Tonse.

Accidcntal Action.

I was struck, cite-noñ-lī-sEn kō.

we were struek, citc-noñ-lī-tlta kō. 
Past Tense, Purposive Action.

$I$ was struck, cteut-oñ-lā-sEn kō. we were struck, ctent-oñ-lī-tlta kō.

\section{Future Tense.}

I shall be struck, citc-noñ-sEn-sä. wc shall be struck, citc-noñ-tlta-sä.

I shall strike mysclf (if I do that), citc-noñet-sEn sii.

\section{Conditionel Forms.}

If I um struek, kwE citc-En.

If we ure struk, kwE citc-Etlta.

\section{Negative Forms.}

I am not struck, aúa-sEn sécitc. we are not struck, aúa-tlta sécitc. I was not struck, ańa-lā-sEn sēcitc. we were not struck, aúa-lā-tlta sēcitc. I shall not bc struck, aúa-sEn sä citc. we shall not be struck, aúa-tlta sä citc

\section{Miscellaneous Phrases.}

what is that? stañ yñ ấtce?

a stone, tse sñánit.

is it a stonc? sñúnit-a?

it is a stonc, sñanit $k \bar{o}$.

which stone? tuqéin ấtce sñánit?

what kind of a stone? stañ niteE utl sñánitEs?

a black stone, nkkéé sñânit.

is that a black stone? ō nEkéEq-a kō tê sñânit?

on a stonc, utsấ sĩánit.

under the stone, klātcilawetl utsî́ sñánit.

it is a goot stone, ể kō sñánit.

one doy, nktsēkwus (skáqqa).

treo logs, tcesēkwus (sḳáqua).

no dogs, aúcna skéáqa.

logs, skinlíqua.

any doys, muk'u skwenéñ skáqua.

many $\operatorname{logs}$, ñun sḳáqa.

jew dogs, ańa sñuñ. 
right ear, tsī mEn.

left car, tsukwáEn.

both ears, tseátcan.

right eye, swếmâles.

left eye, tsēkwâlles.

both eyes, cwetcấles.

vight haud, sēimelä́qEn, sēmékwuss.

left hand, tsekwếyōs.

both hands, sîtcếōs.

right foot, saíalumsin.

left foot, tskikwasin.

both feet, tsetcấsin.

this house, tīa ấloñ.

that house, tsấa áloñ.

these houses, tỉa ïlíloñ.

those houses, tsåa iilâlon.

I want some water, nestle kw's kwā.

N.B.-This word "want," "wish," "like," is one of the most constant of all the Salish terms. It has the same form in all the dialects examined, and is always conjugated with the pronominal forms nE, etc. It is perhaps the best test word of this linguistic stock.

I am thirsty, cấcäsEn.

I want. some food, nEstle kw's sêtlun.

I am hungry, tlúteEsen.

The moon will rise soon, tuQtcilel aiyúna kwän tsE tlskaltc.

uho is that? nētl âteE san tsáa?

give me some water, Enátce kwākwã stóñis.

make up the fire, teuk kō sḱsta.

one trce, snEts ếEtltc' (skelálEnōq).

two trees, uste's éEtltc'.

a small tree, usmémen étitite'.

small trees, usmélemen êEtlte'.

lots of trees, ñuñ skElkelálenōq.

all trees, muk ${ }^{u}$ skelkelálenōq.

few trees, auskwen éEtlte'âl skelálenōq.

one house, nitsaútōe.

two houses, suñtōQ.

maxy houses, ñแñ áläloñ.

small honses (klaklōka, small), aá̉loñ.

large house, tenkaútōe, teuk áloñ.

large houses, teuk áläloñ.

u good man, éi swéEka. 
he is a good man, éi swếEka tī ō nītl.

I am working, tcē-sEn kō.

he male it with a knife, ō cpileten tesqteès.

I am struek with a stone, ts'Étoñ-sEn utsá sñånit.

it is going to rain, tliinoq yoq sä.

it is John's $\operatorname{dog}$, tūQ John skáqqa.

we have some horses, tc'stékkēū-tlta.

my dog is white, kw's (or teE) ne skấqa puk:

your dog is black, kw's(a)unskáqa nek éaq.

come with me, Enátes ésūwa.

bring me the dog, Enaúqtcē ten skấqa.

give me the dog, Eñastce ten sḳáqa.

it is cloudy, Econaúwis.

are you hungry? k'wāiyisQ?

I am hungry, k'wtl k'wáiyisen.

are you cold? tsātluñasQ?

I am cold, tsātluñsen.

did you shoot a deer? tcktlunuk'asQ uk smếyis?

it is John, ō nītl kō John.

he said I was a bad man, aqun kwḱnis skäas swếka.

when yon come in shut the door, ấsQ Enấ nūwēluñ ēnutkutQ sE satl.

these horses are black, tīa stếkē̄u nEk·êEq.

those men are old, tsau nenétlia selálōq.

those girls are bcautiful, tsäa kuñkuñiteal alē.

those vomen are uyly, tsan nenétlia kulkuláma.

I have a dog, te'skíqa-sEn.

you hare a dog, te'sḳáqa-swii.

you and I have a dog, mok'u stukó te' kwa skạ́qa.

we have some horses, ōte' stéEkēū-tlta tukō

he has some horses, ōtc' stếkkēū tō nītl.

my dog is black, tīa nkskáqqa nEk'êEq.

your dog is white, kw's unskwā unskáqqa puk:

his dog is white, tīa (or kw'sii) ō nītl skáquas puk:

our house is old, kw'tl sálōq tī âluñ.

my hat is on the ground, tc' uEsteEsauk sE sauktE.

it is under a stone, tltcalawutl utsă sñánit.

it is in the box, Esnauwetl utsí k'láiyakus.

near me, estásetl $\bar{a}$ úsii.

a stone will sink in the water, tsa sũánit tl'ElteElñēstuñ sä utsä kwā.

come with me, Enáte. ê sūwa úsä.

come home with me, Enátes täk-u ésĩ wa úsï.

go with him, qonēteE èsúwa rtsía.

I will go with you now, yksknsä ésūwa unúkwa tiau Qoù. 
I will go with you to-norrow, yesEn sii ésūwa unúkwa kwōkwáitcilis.

I went with you yesterclay, yéla sen kw'cuntil unúkwa tcilaketl.

lct us go now, héista kw'tlyiatlta.

let us all go, héista yấtlta ō muk·a stíya.

let us go togcther, hếista ō yekwentäl.

let us build a housc, hêista teätcūtwuñ.

let us cat it all, ñasta ó muk-u.

the moon is bright, nūqwalyuñ sä tlkeltc.

the day is clcar, tía anuk yaíyun.

it is fine, éi skwátcil.

he is making a five, tcukwéo tsáa.

make up the fire, Qónatce tcukóse.

light the fire, tcukóse.

give me the horse, nnanq stēkēū.

I can ride, Estcūiit sEn untzéluñ.

I can swim, kla sEn ko stcūat tur̃oñ.

are you cold? tsáttluñ EsōQ?

no, I am not cold, aúa sEn tsấtluñ.

ycs, I am cold, tsătluñ sEu kō.

is he sick? Esqatlatla?

he is sick, Esqatlatl kō.

are you hungry? kw'tlete Esōe?

I am, kw'tletc sen.

is your father dcad? kw'tl k'wól yekwe kwEn man?

ycs, he is dcad, äa, kw'tl k'wối kō.

is he coming? yEún-a?

are you coming? is tla Esōe è yeún-a?

I often go there, ōyá kwénes áauq.

come in, Enấtce nūwéluñ.

go in, áauqteE nūwéluñ.

did you shoot a deer? te' tlunúk'owus auk sméyis.

is it dark? a-tlateE?

yes, it is dark, tlate kō.

is it light? stâtō-ā?

yes, it is light, $\bar{o}$ státō kō.

I vant you to go, nestlē kw'sen sía.

come along, Enátce.

once he came to my house, ō-nFtsauq tíitcil $\mathrm{n}$ E áluñ.

he often used to comc, ō yíla kō kw'sóEnas.

whcn I came in, thc man was lying on the bcd, kwÉnEs tấtcil tsō nītl sEsaút nítsa cwámut.

when $I$ went out $I$ saw him there, kwénes kw'tlía skéluñ èyú kwenétsen sksaút útsa cwámut. 
when you come in shut the door, ásōo nūwéluñ éi nứqtekut tsấasátl.

when you are sick you should take medicine, $\mathrm{kwE}$ Fsqatletlōe ći $\mathrm{k} \cdot \overline{\mathrm{u}}$ kwōkwanïsiñōe.

when it rains $I$ stay in the house, ása tlúmoq éyũ usnáwEtl-sEn sä uk.u 'staleñōq.

when the deer saw me it ran away, nītl $\mathrm{n} \mathrm{E}$ sō kwEnấñus sō kwániñuts tsáa sméyis.

would you not like some meat? ańa Es-un-stlē tsáa sléuk ?

which is your horse? nitl átce tEqếin un-skwit tía stēkćū ?

he stole my dog, ó nītl kō kấnes ú-kwE-nE-skạaqa.

he stole your dog, $\overline{0}$ nītl ko kwänếsa un-skạaqa.

my dog was stolen, ka nêtuñsEn aú-kwE-ne skắqa.

I lost my dog, Hwēl kō kwE-nE-sḳắqa.

I cut my foot, tlētstsesEu.

it is raining, tlumōq.

it is snowing, tcêyulu.

it rained yesterday, thímoq uks tciláketl.

it will rain to-morrow, I think, $\left\{\begin{array}{l}\text { éwa tê } \\ \text { éwā kō }\end{array}\right\}$ tlúmōq sä kō kwátcilis.

if it rains $I$ shall not go, âsā tlúmõq éyū aúa-sEn sä.

where are you? àqềin kw's ē átce ?

I am here, átla sEn kō.

where were you? āqểin līswaátce ?

where do you live? āqếin skwE átce ?

I live here, átlā-sEn kō ō átlī Etía.

I live there, lā-sEn kō Etólō.

he is in the loonse, âtlā tĩ ō usmấwetl filuñ.

where is John? äqểin yūq kw's ē átce kwE, John?

he is on the beach, la áte satsau.

I am a Songish, soñ Es-sen kō.

lee is erying, tsíía ò nītl Qñón.

he is laughing, tsấa ō nītl nEnaíyun.

didl you go? kw'tl yála-sōe?

no, I did not, aúa-sen sīya.

yes, I went, ō yála kō.

lee wont, ō hai la yä kō.

yes, I will yo with you, äa ko ćsūwa sEn.

come aiong then, Enátce.

where have you been? tuQén la swátce ?

I have been for a walk, ō cútuñ-sEn álā.

where are you going ? tuQến swătce ?

you had better not go, ō auitce.

$I$ must go, ō yā-sen kō. 
I an going, yē-sEn.

won't you come with me? à wā-sōQ Enấ ésūwa.

stand up, sétliñ.

I am going, kw'tl nētl nesyá.

go! qonētcē !

you had better go, yätcē.

I am not going to strike, ō aria sEn sa ctuct.

Prepositional Phrases.

on the beach, sấsō.

near the water, Estâsktl utsí kwi.

in bed, kw'tl étet.

on a stone, ts'ïat utsấ sñánit.

in the clouds, uskwâkwa, cwāsíten.

on the water, Eskasetl âtsá kwā.

in or under the water, klāteEtl átsá kwī.

in the shy, sisstl utsî skwâtcil.

in the canoe, èlálitl utsá snúkwEtl.

in the house, ēwusnáwutl utsấ áloñ.

outside, Esáketl.

underneath, k'lātcílawitl.

on the ground, sE sarit utsâ tuñūq.

near or close to me, Enấtce Estásetl.

sit by or near me, Enấtee Estásetl kwEnz ámut.

come along with me, Enătce êsōwa.

I am struel with or by a stone, klumatoñ-sEn utsá sñånit.

he struck me with a stone, ô nïtl kō klumas utså sñånit.

\section{STORY of SuÚtuksen.}

Skwăcin ntlsmeântc. "Enâtce úña uts En-smánite." "Euátcī Skwacin was chewing gum. (Said she) "Give me sone of your gum." "Come-you ésūiva à kwāsesem a kwícqilas Tiuñ smánitc." Nōtl-sō yà̄s with me and I show you where is lots of gum" (said he). Then they went $\mathrm{k}$ 'wācúneten. nētl sō "aqêin ấtce te cwólas te smánitc?" "T'ùq together: Then (said she) "Where is the place of the gum?" "Nearly tcilálatlta ếtīs." Yk-kúmtes tw sélekwus te skēts. . nētl sō èyEthere-we getting" (siid he). She breaks off the fringe-of the blanket-her. Then she

kílkutks. Sō yās ēcutuñ. nētl sō hais te sélekwus. hangs it on the limbs Then they go on walking. Then she finished the fringe. of the trees. 
Nētl sō tūq tcekaíwuks skelukklánliñuq, tus utsì qátca, nētl sō kwáles Then she bent the boughs young trees, they get to a lake. Then spake tE slēĩ. "Sō Enás õ tátcil thuttlalē. "áletl-tcē." Nētl so áletls the crane. Then there appears a shallow-canoe. "Get-in-you" (said he). Then they get in. sō tákwels; nëtl sō tcañs tsäa Skwácin. Nētl sō "nūwēliñ-tcē." Then they cross. Then they reach that Skwacin. Then "Go in" (said be). the home of

Nētl sō nūweliñs. Nētl sō qaiteñs nētl sō slēñistens, sō Then she-went-in. Then she-slipped-down then be picked her np, and amât'Ens; nëtl sō umuts tsäa Skwácin munuts slénli. Nētl sō set her down; then sat down that Skwacin sat down (also) the girl. Then

kwálnūkwel. Skwācin "Kwenála uncwélākwa?" "ápen-tlta" they talked together. Skwacin (said) "How many your brothers?" "Ten-we" (said she) tówa kwālkwels tsan nenêtlia kw’tl-kwal te slēñ. Nētl sō te awhile they talked they when cryout the crane. Then the k'wéstens. "Nētl unskw'kwa?" "Nẽtl" enå nūwéleñ nētl so canoe brings "Is that your brother?" (he asks) "It is" (she replies) then he enters then him over.

tcak'Es, nētl sō nuqtlkwenkwasteñ tsätsâlas, nētl sō tl'pútsets. he slips down, then (Skwacin) takes out the heart his, then he swallows it whole. K'la kw't]-kwal te slēñ. K’la tátcil te nátsa klauaqunátiñ. Again cries out the crane. Again comes another one he does the same to him. aiyūu yaqknátiñ. Aiyū auk $\cdot$ tsä ấpEn. QEoñ $\mathrm{sE}$ then does same to all (the brothers). Then finished the ten (of them). Crying the tāns muk a skwátcil. Nētl sō kwénets tsä k kutcī. Nētl sō tliñas mother-their every day. Then she took some moss. Then she took tsä smútuksen ē yEãqutes útsa $k$ 'útcī, nētl sō muk'u skwátcil, nētl sõ some snot and put it on the moss, then every day, then

kwéukset, nētl sō k’wónes te sâles ē tsä sqúna, sō kwónūq it begins to-move, then she perceives the hand and the feet, then she sees tsä kúloñ à nā sō āléskts. Muk'u skwâteil tcé sEñs SmútuksEn. the eye, then it becomes alive. Every day (growing) it grows into Smutuksen.

Nētl sō yFyāseñs. "Qutsésiñ-tcē kw's nāyétcut." Nētl sō qutēts tw Then he plays about. "Make-me-you a shooting weapon" Then she made a (said he to his mother).

ewōmâtúñ $\overline{\mathrm{e}} \mathrm{k}$ la yétcut, 'nētl sō ctrũs. "Aúa-sõe leléloñ, auk’u bow and also arrowa, then he went hututing. "IJon't you go far away, lost

un-cEcértl." Nētl sō tcuk swéEka SmútuksEn. "Stañ yūQatce your elder brothers." Then big man (was) Smutuksen. "What kind of wood kwE tlāaúq ?" “ē aúa ō kō nuñúna ē-aúa atce so ếi kwEns-tắat?" may be hard?" (said he) "I don't kuow my-son hadn't you better try" (answered she) (for yourself) 


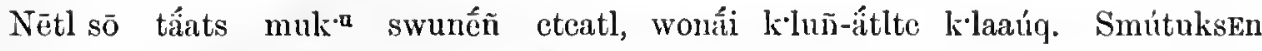
So he tries all kinds of wood, only yew tree hard. Smutuksen

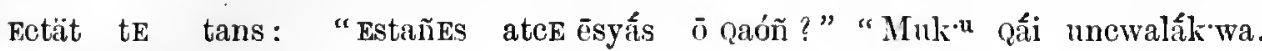
asks the mother-his: "Why always crying?" "All dead your brothers and sister.

ēwa ātce slalakum kwE-tcálık." Aúa skwāls ō lẹlāniñāl. Nētı sō yãas may-be a monster lives in the woods." Not speaks he listens only. Then he goes Smútuksen stuñ qelqallekwets, nētl sō kwónūqs tE seélekwus, nētl sō Smutuksen for a walk all armour-clad, then he perceives the fringe, then yetleấs nētl sō sấūs sō kwāls te slēñ. "Nētl-a he follows (the signs) then he reaches the lake whereupon cries out the crane. "Is that unewákwa sâū ?" "Tūe aúina"; "ha! ha! skwãls tF Skwácin your brother at the lake?" "None left"; "ha! ha! sail skwacin (said Skwacin) (she answers)

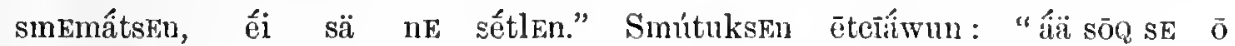
he is shoviug off, fine will be my meal." Smutuksen was singing: "No matter low

slalakum ếwā úsen sï ō teilaúsa." Sinútuksen sō kwēns. Sō great a monster naỵbe I an shall turn you down." Smutuksen then disembarks. When

tus' útsa sātl sō Qêltes stauwok Qếltes nứas nētl sō he reaches the doorway then threw down clay he throws it insile (the house) then nūwēlıñs te Smútuksen, nētl sō kwêutels, nēlt sō nũqtlkwEnkwástiñ he enter's (does) the Smutuksen then they figlit, then he (the Slalakun) thrust his fingers into his heart (Smutuksen's)

nētl sō teltuks te’ sâlic." “Kw'tluētl aúEus qonáĩ ?" nētl sō then they break off his fingers. "Is that all you can do?" (said Smutuksen) then ctcếakwutuñ te Skwấcin, nētl sō kwiskwan te Skwáciu. Nētl sō he struck him on the head the Skwacin, then fell down Skwacin. Then

k’áñi set Smútuksen núqutltcäknt. "Muk•u nE-cwálakwa tsấlas the maiden bade Snutuksen cut him open. "All my brothers' and sisters' hearts usnáwetl." Nētl sō nūqutltcakuts, tuq sanyuq ấtce tsâla tlăa inside" (of him, said she). Then he opens him, whose heart this one (he wonders)

Fstanetl ō nEnētlia Eskwâkwai, $\overline{0}$-tlīmátes, nētl sō halétens.

he lays in a row those dead-ones, he fits each (heart), then he restores them to life.

"hēs-lā kō wī nicwétet." Nètl sō tăkn̄s, tcásteesa kw's-tấkwels. "Long-time liave slept" (say tliey). Then go home, two-by-two cross they.

Smútuksku ètl-kwấwus kw's tâtewels. Nētl sōk'w'teátens tr slēñ, nētl sō Sinutuksen was the last to cross. Then he killed the crane, then

tultustiñ tlitlelâi nētl sō tākūs, ếi-skwâlekwEns sE taus.

he destroyed the ferry-hoat then went home, rejoices the mother-their.

Nētl sō yās tcî́tutl nuk•u nenétlia. Nètl sō kwuqEnuqwels. "Nētl

Then weut duck-hunting all of them. Then quarrel they together. "This is 


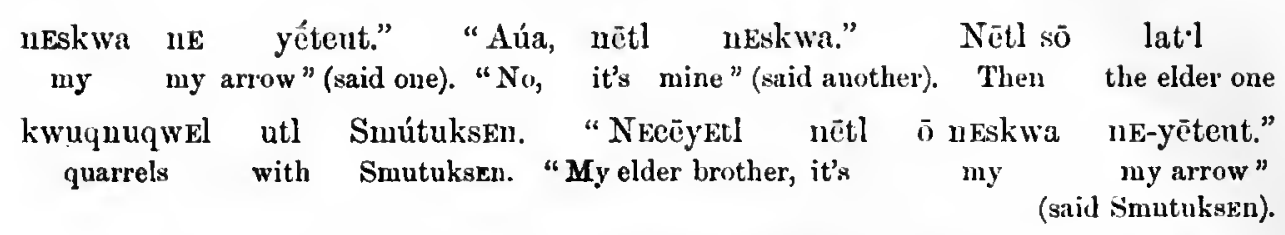

"Aúa-sōe teētluñ utE-úsa, smútuksensōe." Nêtl sō tāteuks, sō tākūs,

"Don't-yon 'brother' me, you snotty-one." Then he becomes angry and goes home, sō teañs nētl sō étñts, "Umut-teè étlunsōę," when reaches home then he lies down, covers his face with the "Sit-up-you, get up," blanket.

set sa tans, aúa skwals, tsä Smútuksen, nētl sō tcáñit aúina, sain his notber, not be replies, that Smútnksen, then she felt him and behold nothing was there, $\begin{array}{ccc}\text { nētl sō twésts } & \bar{o} \text { twāi tsii smútuksEn. } & \text { Häi kwe. } \\ \text { then she pulled back the blanket and lo ! only that snot. } & \text { Finished. }\end{array}$

\section{The Equivalent of above as told in English. By Thonas James.}

There was once a family of ten brothers and one sister; they lived together with their mother. One day the girl went into the woods alone. She saw there a fine-looking man who was ehewing gum. He made a great noise over it. Thought the girl to herself, "What is the man ehewing ? it must be some kind of good gum." She aeeosted the man asking hin for some of his ehewing-gum. Said he to her, "I have no more here, but I will show you where you ean get plenty for yourself. It is only a little way from here." She followed him a little way and then questioned him again. "How long before we shall come to the gum." "In a little while now," he replied, "it is only a short way from here." But she is alarmed now, and fears he is taking her away, so she unravels her blanket and ties bits of the yarn to the branehes of the trees she passes. Before they get to their destination she has used up all her blanket in this way. She now marks her course by breaking off the ends of the twigs and branches in her path. In course of time they come to a lake: as they approaeh a Crane eries out. $\mathrm{He}$ is wateliman to the ogre who had entieed the girl away, and always gave notice of the approaeh of anyone by a harsh ery. When they reach the edge of the lake a little boat appears self-propelled without sails or paddles. It was the ogre's magie boat. The ogre now bids the girl get into the boat. He follows her, and they presently are earried to his house, the inside of whieh is as bright and dazzling as the sun. The floor is also bright and exceedingly slippery, so slippery that wo une call stand upon it. "Go in," said the ogre to the girl, but no sooner had she set her foot upon the floor than she fell down and eould not of herself get up again. The ogre now pieked her up and set her npon a seat. He then asked, "How many brothers have you?" "Ten," she replied. 
Now when the girl did not come home that night her brothers and mother were very anxions about her, and on the following morning the eldest set out to follow her track. He had no difficulty in doing this on account of the bits of yarn tied to the trees and the bent and broken twigs. In course of time he reached the lake and the Crane gave his warning cry. The little hoat next appeared into which the young man stepped and was taken to the ogre's house. He stood at the entrancc a moment and the ogre said, "Come in, my friend, you will find your sister here." The youth entered, but as soon as his feet tonched the slippery floor he fell prone upon his back. Thereupon the ogre thrust his fingers into the young man's breast and tore out his heart and swallowed it. This done he set the dead body aside out of the way. The eldest brother not returning, the second set ont in search of him and his sister. In due course he arrived at the ogre's honse and met the same fate as his brother. In like manner each of the ten brother's setting out one after the other werc decoyed to the honse of the ogre and there done to death by him.

Now the poor mother was left without sons or danghter. She cried for many days. At last she took a bunch of moss, in the centre of which she placed some mucus from her nose. She watcher this day by day; soon the mucus began to show movement, a little later a hand appears, then another and also the feet. Next she perceives the facc and eyes. Then it becomes alive and grows into a stout boy baby. The mother now tends and cares for this new child, and he quickly grows into a big strong boy. "Make me a shooting-weapon, mother," said he. The mother complied, and furnished hin with a bow and arrows. With these he would go ont hunting. Before he went away his mother cantioned him about wandering too far off, telling him how she had lost all his elder brothers and sister. Smútuksen was fast growing to manhood. One day he asked his mother, "Which is the hardest kind of wood ?" "I cannot tell you my son," replied she; "hadn't you better try for yourself." So he tried all kinds of wood, and found the yew-tree best suited for his purpose.

Now his mother had not ceased grieving for her lost children and Smítuksen often found her erying. "Why do you cry so much, mother ?" he asked one day. "I cannot help grieving over your lost brothers and sister. I think they must have been taken by an ogre that lives in the forest." Smituksen listeus to his mother's conjecture concerning the disappearance of his, brothers and sister, lout says nothing. He went out thoughtfully clad in his armour and presently came upon a piece of the fringe of his sister's blanket still hanging upon the bush where she had tied it. He looked about and saw the next piece, and thus found the trail his sister had left. He follows this up till it brings lim to the Lake. When the Crane saw him it gave forth its croak of warning. Upon this the ogre, who had heard it, asked the girl if she thonght that was another of her brothers coming to look for her. lieplied she, "I have no other brothers." Smútuksen now began to sing. "You may be ever so great an ogre but perhaps you will find your master in me." "Ha! ha!" laughed the ogre, " hark at the boastful puppy. What a nice 
meal he will presently nake for ne." Meanwhile Suntukskn was crossing the lake in the magic canoe. Now he had brought some pipe-clay with him, and when he reached the doorway of the house and saw the slippery floor he threw some of this upon it. By this means he could walk over it without falling or slipping down. He now enters, and a conflict begins between the ogre and Smuttuksen. The ogre, as was his wont, thrust forth his claw-like fingers and tried to tear out Smútuksen's heart, but he had found his match this time. His fingere broke off against SmútuksEn's armour. "Oh ! oh " mocked Smútuksen, " is that all you can do? take that for your trouble," and with that he struck him a great blow on the head which felled him to the ground. The girl, who had observed the fight, now ealled upon SimútuksEn to eut the ogre open. "He has swallowed all my brothers' hearts," said she. Smituksen eut the ogre open and found the ten hearts inside him. "I wonder whose heart this is?" he remarks as he pulls out the first. When he has taken out all the hearts he lays the bodies of his brothers in a row and fits into each the heart belonging to him. This done he restores them to life. "Dear me," says each, "I must have slept a long time."

They now set off home, crussing the lake two at a time. Last of all came Smituksen and his sister. When he lands he turns and smashes the canoe to pieces. He also kills the Crane. Soon they reach their mother's dwelling, and great is her joy at the recovery of her children.

Some time after this the brothers all go duck-hunting together, but when the shooting began they fell to quarrelling among themselves as to whose arrows brought down the ducks. The eldest brother elaimed them, but SmútuksEn said, " $O$ my elder brother it is not your arrow, it is mine." Thereupon the elder brother got angry and said to Smituksen, "Don't 'elder brother' me-you are not my brother; you are only a snot-mau." This remark wounds Smútuksen so deeply that he leaves the others and returns home alone. When he reaches the house he goes in and lies on his bed, covering himself entirely with his blanket. Presently his mother comes to him and bids him uncover himself and sit up, but she gets no response from him. Then she pulled back the blanket and behold he had ehanged back into nose-nucus again and was no more a man.

\section{Mrmhaias' Grandson.}

There was once a chief named Mrmuaías who had ten sons and one daughter. The latter after the eustom of chief's daughters was a claunun, that is, she led a very secluded life, rarely if ever leaving her father's dwelling during the day.

One night she was awakened by someone pulling her blanket aside, "Who's that?" she asks. Her visitor's only reply was a request to move over a bit and make room for him. He lay with her that night and she repeatedly asked who he was, but received no reply to her question. On several successive nights her unknown lover eame to her, but she could never get hin to reveal his name or tell her who he was. All she knew of him was that he possessed a fine head of hair. 
In conse of time the girl found herself with child, and was much distressed thereat by reason of the shame it would bring upon herself and family. She now set herself to discover the identity of her nightly visitor. To do this she took some deer fat and mixed it witl certain ochres, and smeared the palms of her hands with the compound, and when her lover lay with her that night, she left an impress of them upon his shoulders. Now it was the custom of the youth of the village to engage in various athletic exercises in the early hours of the day, to perform which they always threw aside their blankets or tunics leaving their bodies bare. On the morning following the girl begged to be allowed to go out to see the young men go through their exercises. At first lier mother refused her request, but finally gave way to her importunities, and allowed her to go well shrouded in her blanket. When the young men stripped for their contest, almost the first sight that met the girl's gaze was the imprint of a pair of hands on the shoulders of her younger brother. She is horrified at the discovery, well knowing the deep shame and disgrace that must fall upon her family. She returned to the lodge and all that day she sought to find some way by which she might spare her parents this dreadful disgrace. She could see but one, and that was for herself and brother to steal away quietly from the camp and hide themselves in the depths of the forest. So that night when her brother came to her, she told him of her condition, and that she knew who he was, and urged him to leave home with her, to spare their father the deep shame that his conduct must bring upou him if she remained till her condition was discovered. He consented to her plan, and they left the camp that night before anyone was stirring, and betook themselves to the forest aud mountains. They travelled continuously for twice four days, then the girl said, "We will stay here and build a shelter for ourselves." This they did, and in course of time the girl was delivered of a fine male ehild. The child grew amazingly and soon becante a strong boy. One day he was out shooting with his bow and arrows a little way from home when he saw a great fire in the direction of his parents' lodge. He hastened baek and arrived just in time to see the roof fall in. He called aloud to his mother and father, lut could get no reply. That night it was revealed to him in a vision who his parents were, what they had lonc, why they liad left home, and how they had planned to wipe ont their offenee by self-destruction. He learnt also the name of his grandfather. The boy determines now to seek the latter. To this end he calls upon his totem the woodpecker, and asks his assistance. The woodpecker promises to guide him to his grandfather's lodge. The boy cuts himself a staff and the woodpecher perches upon the top of it, and they thus set fortl. As they went the boy sang and cried alternately. The words of the song were, "Oh! my father and mother are burnt to deatl, and my grandfather is MEmHaías."

As he neared his grandfather's village, a woman who was gathering shell-fish on the beach heard liis song and called out to MEmHaias' wife, who was sitting out of doors engaged in basket weaving, and told her that someone was singing in the mountain about her husband MEmHaías. The wife called out and told her husband 
what the woman was saying, and he bade her go down to the beach and listen for herself. She went down and the women said to her: "Look towards the mountain and listen." She listens and hears her grandson's song, "Oh! iny father and mother are burnt to death, and MEmhaias is my grandfather." The old woman now calls her husband to come down and hear for hinself. The day was very fine and still, and the sounds carried a great way. He goes down to the beach and listens, and presently hears his grandson's plaint. Memuaias now calls his friends to listen, and they decide to go up the monntain and seek the singer. After some time they come upon him, and find that he travels in a very singular manner. He takes but one step to each repetition of his song, and it thus takes them fifteen days to get him down the mountain. When he arrives he tells his story and what he had learnt in his vision; and the mystery of his parents' sudden disappearanee from their home was thus made known to his grandparents. They sorrow much over the sad end of their son and daughter, and send out a seareh-party to see if by any chance they had not perished in the fire. But no one could get near the spot where the house had stood, the fire had spread itself for miles on all sides, and was still fiereely burning, and nothing was ever afterwards heard of the unhappy pair who had thus deliberately planned their own death to wipe out the disgrace of their lives.

This story recalls one which I gathered some years ago among the Thompsons of the Interior, but is less graphie and much shorter. I an not disposed to think the Lekninen version is derived from the Thompson. Each I think is independent of the other and both equally interesting as exhibiting the shame and disgrace of incestrous unions.

\section{Myth of tile Gilost-Lover.}

Once a long time ago the Soñes made a successful rail upon the Síciatl, and returned to the island with many heads, which they stuck upon poles set up in the village. Now it happened that the daughter of the ehief of the Sones was passing by where the heads were set up and looking upon them compassionately observed that one was the head of a very handsome young man. She was moved to take this head down and cry over it, earessing the beantiful long hair as she did so. For twiee four days she daily fondled and eried over this head. At the end of that time some one came to her eonch that night. She asks, "Who are you?" and received the reply, "It is the man whose head you have been fondling and erying over." For several sueeessive nights her ghostly visitor appeared to her in this way.

One night he said to her, "To-morrow night I am going to take you away with me to my old home; I have a brother who lives there, who is just like me. When you arrive at Síciatl elimb the mountain and you will see a lot of mountain-goat wool which you must make into blankets. I will be with you all the time till you meet my brother, whum I want you to marry." About the middle of the following night thc ghost-man came to her bedside and said, "If you are ready, come." She 
got up and followed him out of the house. On the beach was a eanoe with many paddles in it. Said the ghost-man, "Get in and cover your head with your blanket." The girl does as she is bidden, and hears nothing but a sueeession of "Olıs! Ohs!" Not a sound of "paddling does she hear, and before she is aware of it the eanoe has neared its destination. The ghost-lover now bids her uneover her head and get out of the canoe. "This," said he, "is where my brother lives." They climb the mountain and she finds quantities of wool. This she gathers and prepares and nukes into blankets. Every morning she finds the carcase of a goat elose by the shelter she had made for herself. She stayed here on the mountain spinning wool and weaving blankets for a whole year. At the end of that time one day she met a young man. She looked at him closely and saw that he was very like her ghost-lover. "This must be his brother," she said to herself. She hung her head and began to ery. The youth said nothing and presently left her. He goes home to his mother and says, "I met the finest woman I have ever seen this morning on the nountain. I wish you would get her for my wife. When you ask her, tell her I am the young man she saw this morning."

The parents of the youth went to sce the girl, and found her busy weaving her blankets. The mother opens the conversation by asking the maid if she remembered seeing a young man lately. She answered, "Yes, I saw lim." "He is my son," said the old woman, "and he wants you to be his wife." "I will go with you," replies the girl remembering her ghost-lover's wishes. They descend the mountain together. When they arrive at the old people's dwelling, they ask her how she got to their part of the country. "I was brought here by the ghost-people," said she, and thereupon tells them her story. When she speaks of the strong resemblance between their son and the head she had fallen in love with, they cry out and say, "Alas! it was om son his twin brother." The father then says, "I will send you baek to your people with my living son, but we must first find some one who knows the way." He thereupon ealls in the Elk and asks, "Do you know the whole country round?" "No," replies the Elk, "I am aequainted only with open glades." He then calls in the Deer, and puts the same question to lim. The Deer replies, "I know parts only of the country." The old man then called in one animal after another, but no one of them possessed the neeessary knowledge, till he came to the Mink. Mink replied to his question, "Yes, I know all the eountry, and I know, moreover, this girl's father's name. He is ealled Miñqaias."

The old man now sent for the store of blankets the girl had in her mountain hornc. There were many bales of them, far too many to put into their canoes. So he ordered them to make a great raft by neans of their canoes. Upon this he placed the bales of blankets and then set out with his son and daughter-in-law and friends, with Mink to guide thern.

They follow the coast till they reaeh the country and settlement of the Sk-qómic. Here Mink calls alond for Miñqaias. They learn that no such person lives there and proceed on their way again till they reach the settlement 
of the Muskqiam, at the mouth of the Fraser. Mink ealls aloud for Minqaias here, also, but is told no such person dwells there. From Muskqiam they proceed to the setilements of the Stewiskn, and from thenee to Semiahmoo Bay, but meet with no better success. In none of these places lives Miñaias, the father of the girl. Next, they call at the settlements of the Tlumi. Here Wolf comes out and says, "You have ealled at the wrong plaee. If to-morrow morning you will follow the sun you will come to Miñaias' country."

On the morrow they follow the course of the sun, and at dnsk they come to a mountain ealled Skálakcmm. Here they wait till the moon rises, when they follow it throughont the whole night. At sunrise they approach a village and Mink ealls out as usual for Miñqaias. Now, there was a woman on the beach gathering cockles, who, when she heard Mink calling for Minqaias, leaves her cockle gathering and runs to Miñaias' dwelling and informs him that some people on a large raft are calling for lim.

When Miñaias hears the woman's words, he bids his people prepare themselves for war. Said he, "They may have eome to fight with us." Miñqaias and his people placed themselves in readiness, and would not go near the raft. When the girl saw that her father feared treachery she stood up and called aloud, "I an Miñaias' daughter; I have returned and brought my husband and his friends with me." When Miñaias hears and recognises his daughter's voice, he cries out for joy, and bids the people go down to the water and bring the raft with its contents into his house.

This they do, but so large was the raft that they had to take down the side of the house to bring $i t$ in. The girl now relates her adventures and all are greatly astonished at her story. Miñqaias entertains his guests royally for several days. He also inquired of them how long they had been coming, and learnt that they had been two moons on the way. The father of the young man asks Miñqaias if he cannot show them a shorter way. Miñaias promises to do so, and says he will ask his brother who lives in the sea.

The name of this "brother" is Stéqwi. Miñqaias goes to the top of the mountain, and calls out to his brother of the sea. The latter replies and asks what he wants. Said Minqaias, "If 1 want to pass quickly from one end of the island to the other, how can I best do it?" "I will tell you," replied Stéqwi. "Whenever you want to travel on the water take the eourse of the current. This goes in one direction for half the day and in another for the balance of the clay." Miñqaias thanks his brother, the Stếqwi, for his advice, and returns to his guests. He then calls to him all the animals and asks them if they know the way to follow the ocean currents, but none but Sea-lion linows, and he requires much food to eat on the way. Miñqaias calls upon his brother again, and asks him to supply them with food for Sen-lion. Stêqwi promises to send the salmon along with them. Next morning the visitors bil Miñqaias adien, and set off under the guidance of Sea-lion. P'resently they strike the emrent and find the - Sahnon travelling with them. Sea-lion and his people bave, therefore, plenty 
of food by the way. The eurrent earries thern to a small island near Sechelt Bay. Here Sea-lion rises to the surface with the towing line in his mouth, and informs them that they are at home.

For this reasoln the sea-lions of to-day always travel by means of the ocean currents, and the Indians say that objeets drift from the island to the mainland and back again, by regular and periodie currents; and they believe these currents were caused by Stéqwi, the "brother" of Miñqaias, as related in this story. They further say that this intermarriage of the Soñes maiden and the Síeiatl youth in the manner related, was the origin of the peace and friendship which have existed ever sinee between the two peoples.

\section{STORY of SqúlekEn.}

There was onee a boy who had three uncles. The name of the eldest was Tl'tākeltūq, that of the seeond, Tl'töeslánuq, and that of the youngest, Ts'kwímet. Whenever his uneles gave a feast this boy disgraeed them by lieking off the platters and dishes like a dog. This habit made the people laugh at him, and brought shame to his uncles. Said the eldest to the others, "What ean we do with sueh a nephew? I will kill or drown him." "No," said the youngest, "you must not kill him. Tou had better punish him in some way." The eldest unele then took a handful of eedar tips, and rubbed the boy's face till the blood eame. "Now," said the youngest unele, "if you take some of the priekly clust of the white pine and fill his eyes with it you will punish him well." One of them objected, saying, "Why do that? You might as well kill him outright as blind him." Replied the youngest uncle, "I don't agree with you; one can never tell what might happen; perhaps something good may come of it." "All right," now say the others, "do as you say."

Upon this they fill the boy's eyes with the priekly bark clust, and take him into the mountains, and leave him there. The boy, thus left to himself, wandered about for four days. At the end of that time the eldest of the mucles went ont one evening and was startled to see flashes of lightning coming from the direction of the mountain where the boy had been taken. Said he to the others, "I have seen a strange thing; I saw many flashes of lightning eoming from the direction of our nephew; lightning at this time of the year is very unusual ; I wonder what it means?" All the uneles now go outside and sit and talk and watch the lightning. l'resently the youngest said, "I had better go and see what this strange thing means." He went to that part of the mountain where the boy had been left. As he approached his nephew called out to him: "I see you eoming, uncle, don't come any nearer to me or you may be harmed. Swówas, the Thunder-being, took away my blind eyes and gave me new ones instead, and these flash the lightning you have seen. I want you now to make me a honse without any rocf; make the walls of new mats (sîläts) which have never been used before." The man returns to his brothers, and tells them what he has discovered. 
The uncles now feel proul of their nephew and his mystery powers, and forthwith build him the house he asks for. The boy's face shines and gleams like fire, and whenever he opens his eyes they emit flashes of lightning.

When the uncles have finisher the house, the youngest of them went to the mountain, again, and told the boy that it was ready for him. "Very well," said the youth, "but don't take me till the evening."

That evening the uncle conducts him home again, the nephew keeping his eyes closed the whole time. As soon as he is within his honse, he opens lis eyes and the lightning flashes through the roofless dwelling into the upper air.

The nephew now instructs his uncles to go and tell the people what has happened, and bid then come and learn what his name for the future would be. The uncles did as they were bidden, and called together all the people of the SnEnaimor, Pentlateh, and neighbouring tribes. When the people had come together and stood round about the new house feeling much afraid of what might happen, they saw the lightning flashes in the air and heard a voice as it were from the clouls, singing "Sqáleken!" This was the new name of the youth. Sgáleken now asked his youngest mucle, "Whieh is the highest mountain you can see ?" The uncle replies, "Cxisip." "Take me there," said the youth. They go to the Cḱlsip inountain, but it is not high enough. The mountain on Salt Spring Island seems to them to be the highest and they go there. "This will do," said the nephew. The mele now builds another house on the summit of this mountain and digs a well for water. The youth looks all round him and sees a small bay in the distanee, the sand of whieh was formed of broken clam-shells. Said he to his uncle, "Do you see that beaeh yonder"?" "Yes," said the uncle. "Go there then, and fetch a canoe load of that shell-sand." The unele did as he was bidden, and when he returned with it, his nephew instructed him to put it into the bottom of the well to line it. The unele did so and the sand may be seen there to this day on the top of the mountain.

Now the youth possessed a big hat, and when he desired a wife he would not go for' her himself but sent his hat with his uncle, who said, "Sqâleken's hat wishes for a wife." In this manner he acquired many wives whose fathers kept him and them supplied with food, earrying it to the house on the mountain.

Now it happened that another man with mystery power, Swítkn, by name, liverl at that time on the Chimainus River, and one day SqâlekEn sent his hat to him. Said Swíten to his messenger, "Who is this upstart who sends and demands gifts of me? I am Swíten kn Skwail, the heaven-born; for whom does he take me? If he wants anything from me, why does he not come himsclf like a man, and not send me his hat? Go back and tell him that I don't want his hat, I want to see himself." The messenger returns and reports. "Oh," say's SqâlkkEn, "he wants to sce me, loes he? Very well, I will go, but I think he will be sorry." All the people round about that part of the country now came together to see the meeting of Sqfileken and Swíten. They filled the house of the latter. Sqấleken arrives, his eyes thashing like lightning all the way, but Swíten lies on his baek on his coueh 
and says nothing. The visitors speak to him, and say, "What are you going to do ? Sqấleken wants your daughter to wife." But Swíten pays no heed to them, but continues to lie on his back. After the people had pestered him a good while he arose and said, "If Sqâlkken wislıes to be on friendly terms with me, let him keep lis eyes closed. I have power as well as he, and ean do him hurt if I wish to." SqúlEkEn thereupon closes his eyes and makes no display of his powers. Switen then gives him his daugliter, and Sqấleken returns to his mountain-home with her, and waits for Switen to bring him food, as the fathers of his other wives had done. He waits day after day until a considerable period had gone by, but no Swíten appears. He gets tired of waiting and bids lis wives dig some lúkumas roots. Said he to lis new wife, "I will go and see my father-in-law; something must be the matter with him, I think. You prepare three canoe-loads of gifts." They set out to go to Swíten's, and on the way meet him on his way to the mountain-house of SqấlekEn. "Hallo," says Sqấleken, "I was eoming to see you, father-in-law." Swíten replies, "I think you had better turn back again." "Oh no, I won't do that," said Sqáleken, "you go baek." Each then tries to persuade the other to turn baek, but neither would yield, and in the end, to get over the difficulty, each agrees to return to his respective house. Now the "power" of Switen was the west wind. They had not long separated when a great storm arose, and rain-drops fell as big as a man's fist. Saicl Swíten to his people, "I'll teach that man a lesson; paddle me to the land." When he is landed Swíten jumps into the water and splashes and tumbles and dives, singing all the while his magie wind song. The wind rises higher and higher, and the trees are broken and dashed to the ground, and their seattered branches fill the air. Presently the stor'm reaches Sqáleken and overwhelms his canoes, and he and lis eompany are obliged to swim ashore. When they get home the youngest of the uneles says to the others, "Brothers, I am astonished at the manner in whieh Switen has treated our neplew; he is eertainly the more pawerful man of the two; our nephew will now be shamed in the eye of the people. They will be exceedingly angry, and will probably seek to kill him, and so disgrace us and our children. I think we had better put him out of the way ourselves and so avoid a publie disgraee."

They listen attentively to lis remarks, and the eldest replies, "But how will you kill him? You can't elub him to death, his glanee would burn you up." "Olı, leave that to me," answered the youngest, "I know what to do." He therempon began to kill a number of hair-seals. The brothers then give a great feast, and eall all the people together. The flesh of the seals is roasted, and distributed among the guests, among whom was Sqăleken himself. The unele who had undertaken to kill him now instructed the others in this wise: "I will presently go behind SqấlEkFn and throw a seal-skin over his face, and then while his eyes are covered you must rush forward and elub him to deatl. Get a stiek of hard wood, and use it for a poker."

In the meantime Sqáleken lay upon his bed with averted faee. When they were ready for the deed 'Ts'kwímet said to his eldest brother, "Brother", stir the 
fire with your poker, it is going out, I think." 'The eldest brother took the pokerstiek, and made as if to stir the fire, and at the same time T's'kwimt threw a sealskin over the head of Sqiflelien, and before the latter eould throw it off and use his eyes, the other brothers had brought the poker down upon his head and brained him.

When the people pereeived that Sqáleken was killed, they shouted for joy, so greatly had they dreaded his terrible powers, whieh even in his death had not wholly left him. In burying him they liad to use the greatest care that no part of his boly was left uncovered; the exposure of even a finger or toe resulted in grievous thunder and lightning. After his corpse had been disposed of, the fathers of the various brides came and took them away.

\section{Myti of Nemókis ANd tue Tes Brotiels.}

There were once ten brothers living in a Sìyálek•u. They were very big strong men. Besides the ten brothers there were many other people in the village, whieh was situated on a small rocky islet. Every morning the sea-lious used to go there to bask in the sunshine. The people used to try and eapture the lions, but only the ten brothers were ever suceessful. This made the others jealous of the brothers, and one old man plots to bring trouble upon them. He went to the woods and shaped a sea-lion from a bloek of eedar, near by a small lake. When he had fashioned its exterior, he took some leaves of the salal-berry bush to form its liver, some moss for its fat and its fur, and eedar boughs for its beard. This done, he made a strong "medicine" from certain herbs, and with it washed the cerlar-lion all over, and then placed it in the lake. Presently it became alive and swam about, but it could not live, it was too buoyant. So the man drew it ashore, and put some stones inside to make it heavier, and then bid it try to dive again. This time the creature was able to dive as well as swim. The old mann now instruets it in this wise: "From this lake to the sea there is an underground passage; you must dive down and eome ont on the open sea. You will see my village there on a small islet. When you reach it, mingle with the other sea-lions and lie and bask on the shore with then."

In the meantime the ten brothers had heard of the work of the old man, and had made up their minds to destroy his cedar-made lion at the first opportunity. With this intention they started ont one morning to spear sea-lion. Said the eldest to the others, "I will certainly smash it if I see it. After all it is only wood, and I ean smash it easily." Presently they perceive a large sea-lion on the roeks. "Ah! that is surely it," said the eldest. "All of you give me your spears and I will do the spearing."

When the cedar-made sea-lion perceived the brothers coming he made for the water, but before he had time to dive, all ten spears were stieking in his hide. He rolls over and pretends to be dead, and floats away seawarl. Now to the point of each spear a line was attuched, and that of the second brother adhered mysteriously 
to his hand. He cries out and asks what he slall do, shall he cut it. The others all reply "Yes." But he is mable to do so, and is being dragged out to sea in his canoe by the floating body of the sea-lion. The others follow in their eanoes, and the youngest bids each man use his "mystery" powers to the ntmost to save their brother. But not one of them has power to stop the floating carcase and release his brother's hand. The youngest then said to the others, "I will try what I can do ; take up your paddles and whip the water with them, and sing your songs." But the youngest. can do no more than the others, and they follow their brother northward for several days till they come at last to a mountain in which there are many sea caves. Here the mock sea-lion stops and lets go of the line which he had been loolding in his flipper up to this time, whereupon the line left the man's hand, and he was free from it. The magie creature now entered one of the caves, and the ten brothers, not knowing what else to do, followed it in. Said the eldest, "We can never find our way back alone, we have been travelling day and night for a long time now, we had better see what is in this eave." So all ten of them enter and follow the sea-lion.

When they are well within the caves they come upon a number of women and ehildren, and some of the women have no clothes on. They have skins which they put over their heads, but are unable to draw them down lower than their breasts till they enter the water. They are the wives and children of the sea-lions whose home is in the sea eaves. Presently the chief of the Sea-lion eame forward and said to the mock-lion, "You should have sent word you were bringing strangers with you." He rephied, "I did not know they were following me." The chief was much perplexed, and did not know what to do with the ten brothers. One of the elders suggested that they should send them home to their own country, and let five of the young men show them the way. The ehief now turned to the brothers and asked the eldest where they had come from. "From the soutl country," he replied. "If I send five of my young men to take you home, will you go with them ?" the chief asks. The brothers say "Assuredly." "But," said the young sea-lions, "five of us eanuot drag ten canoes." "Will you put aside five of your canoes?" They consent to do this, and forthwith five of the canoes are ripped up the middle and the paddles set upright in the cracks. These the sea-lion people turn into liller-whales, the paddles bccoming the large dorsal-fin.

The chief then warns them to avoid the point of the island. "The monster Nemókis," said he, "lives there, and he is always on the look out for sea-lion. If he sees you he will come ont into the water and kill you. Make a wide detour at this point, and so avoid all risks." The five young sea-lions now take the canoes in tow across the gulf. When they near the point where the monster NEmókis dwells, the eldest of the brothers says, "I am going to see this NEmókis and try and slay him. Let us go in closer." $A$ s they are near their own country, the sea-lions now leave them, and the brothers paddle their canoes towards the point where Nemókis had his home. As they drew near., Nemókis perceived them 
and came down into the water towards them. The brothers cast their spears at him but they fall back from his body as if they had been thrown against stone. Presently the monster reaches them, and picks up the five canoes and carries them in his arms to his house. Now, for wife, Nkmókis had a small urine vessel called Cwếála, and whenever she wanted to draw NFmókis' attention she would scream. This was the only sound she could make.

Nemókis kept the ten brothers in lis dwelling, and it was her task to warn him if his eaptives sought to escape. But the brothers were unaware of this at first. The eldest planned to escape. Said he to the others, "Let us cook a lot of food when NEmókis is away hunting, and when we are ready we ean load the canoes with it and get away." So they prepared as much food as they thought wonld be necessary to serve them till they could get home. When it was ready they seized an opportunity when Nemókis was out elk-hunting to carry it to their eanoes. But Cweála began to scream and Nkmókis came striding back with his long strides and took the brothers from their canoes before they had gone a hundred yards, and carried them back to lis dwelling agaiu. Several times they thus thought to escape in NEmókis' absence, but each time Cweála gave the alarm and brought Nemókis upon them. After the first attempt when Cwéila screamed they rushed back to the house before Nkmókis could see them, and when he came in he would question them as to the reason of his wife's screams. As she could not talk they made excuse caeh time. One time they said they hal put too much wood on the fire, and made the house very lot and alarmed her. Another time they had let the fire go out, and she screamed to call attention to the fact; and so each time they had a new excuse. They now saw it would be impossible to get away while Cwéila was about or could see what they were doing. So they took some stones and covered her up, and then set to work to cook a fresh supply of food. When this is ready one of the brothers suggests that they should smash the urine vessel. They agree, and stealing up quietly belind it, they cast a great stone upon it and crush it, and the blood begins to flow. They then rush for their canoes and paddle off as quickly as they conld.

At sunset Nemókis comes home. He perceives the stream of blood at once, and flies into a great rage. He shakes the earth with his stamping and raving, and rushes into the water to overtake the canoes. He almost reaches them before the water is too deep for him. In his anger he seized great masses of rock, and cast them at the eanoes. But the brother's happily escaped him. He ceased not to throw the rocks about for a long time, and they fell all over the country, and that is the reason why so many boulders are now seen scattered over the land fur from their mountain sources.

\section{Myth of the Man who Changed his Face.}

There was once a young man who fell in love with a maiden, but she repulsed him, telling him he was not handsome enough for her. This grieved and hurt him, 
and he went to his grandmother to learn how he might improve his looks. The old woman instructs him in this wise. "Take some deer fat and red paint and go into the forest and follow the trail to the prairie beyond. In the centre of this prairie you will see a colımn of smoke rising. Go towards this and you will presently eome to a lodge. This is the home of the Faee-maker; he will give yon a new faoe for your old one if you ask him." The young man set out to seek the home of the Faee-maker, and after many days' travel arrived at the edge of the prairie his grandmother had spoken of. It was about mid-day. He sees the smoke in the distance and makes towards it. When he gets elose to the spot, he pereeives that the smoke is coming out of a small hole in the ground. He looks down the hole and his body easts a shadow below. Within the underground house was a man who when he saw the shadow oried out: "hep! hep! hep!" He thought it was a clond passing over. The youth looks down a second time and again darkens the interior. "That's a strange eloud," tlinks the man and looks upward and pereeives his visitor.

"Hullo! is that you?" he calls ont, "Come dotwn." The youth begins to climb down. The floor seemed far below him, but as soon as his feet were inside, the floor came up to meet him. The old man now asks him what he had bronght. Said he, "I have this fat." "What else have you got?" "I have also this red paint." "All right," said the old man, "give them to me and ehoose your face."

The youtl looked round the place at all the faces but found none to his liking. Sail he, "I don't like any of these I see, haven't you some more ?"

The old man" then opened a chest and offered its contents to his visitor. The latter looked them over but found nothing to suit him there. Said he, "I don't like any of these either." The old man opened his last ehest in which he kept his best faces, saying as he did so, "How will these suit you?"

The young man saw amongst them a face that pleased him, and said, "I will take this one." The Face-maker now removed the youth's own head and replaced it with the one he had chosen. When this was accomplished he instrueted the youth thus: "When you return to your own country be careful to keep away from yonder mountain. A witch woman lives there who devours everyone she gets within her elutches. No one ever eseapes her if they go near her abode. Her name is Zōllâlats; be eareful of her." Now the young man was a great runner, and he despised the advice of the Face-maker, and went near the mountain trusting to his fleetness of foot to save him if the witch sought to seize him. As he passed he heard a voice say, "Come back to me, my liusband." He looked behind him and saw a monstrous woman as tall as a tree coming after him. He took to his heels," but in a few strides she eaught up with him and seized him by his belt, his feet dangling on one side and his head on the other. Thus she earried him to her dwelling.

Now she kept as slave a handsome young woman whom she had eaught, and as she entered she said to her, "Teigtokn, look at my new husband; isn't he a fine 
young man." The youth sought every opportunity to escape but found none. Every night he slept between her huge breasts, and if he tried to steal away she awoke in an instant, and grasped and placed him in his place again. She kissed and fondled him for a while and then after her manner swallowed him whole. It was now his turn to be avenged, and he took her heart in his hands, and squeezed it till she cried and rolled in agony. Not knowing the cause of her pain she sent for all the animals to come and try and heal her. She asks of them: "Which of you is the best doetor." Bhe-jay, who was a seuwa, claimed the distinetion. He sang his "medicine-song" over her, but as she got no better he remarked to the others, "I don't think we can cure her, I think sle will die." But Smolwwa the Crane said, "Here, let me try what I can do? all of you beat time to my song with your sticks." "All right," said Crow, the spokesman of the crowd. The Crane then put his long bill into the stomach of the witch, which, the youth perceiving, caught hold of and firmly held. The Crane tried to withdraw his bill and struggled with all his might. Presently the youth let go, and the Crane fell back with such force that he turned a complete somersault. He knocked all the breath out of his body, and lay on the ground a moment to recover. Said first one and then another, "How was it Crane could not pull out his bill? It can't be just a sickness, I believe there is somebody inside of her:" All this time the witch is crying and rolling with the pain, and presently she expires. The slave woman now says to the people, "Cut her open, therc is a man inside of her."

They cut her open, and the young man comes forth alive.

The woman now takes possession of all the witch's property, which was immense. With the help of the young man she makes a raft and places all the property npon it, and together they float down the river to the salt water where the father of the young man lived.

The latter had been missed, and all his friends had wondered where he had gone, and were now much astonished to see him return with a handsome young wife and a saft full of property.

When the maiden whom he had formerly wooed saw him, and how handsome he had grown, she desired now to become his wife. But he rejects her in the same manner that she had rejected him, and tells her she is not handsome enough for him. . She learus now how he had got his handsonic face, and determines to go and get hers changed. She accordingly set out and in due time arrived at the Face-makcr's home and requested him to cliange her face. He did so, but gave her a head with a frightful countenance so that she became hideous in the extreme. Thus was she punished for the rejection of her lover.

\section{Stony of Cwot tire sister of Raven.}

Raven once upon a time went to pay his sister Cwot a visit. She welcomes him, and he bids her call in her clildren. She goes outside and plucks a spray of blackberry bush and returns to the house with it. She planted the spray in the 
ground and began to sing. Thereupon the spray blossomed forth and berries appeared upon it. Cwot collects them in a dish and sets them before Raven. He is much gratified and eats his fill of them. After his mcal he leaves, telling her as he goes that she must come and see him soon. She promises that she will do so: Some little time after she went to see him. When she arrived Raven very unetuously bade her welcome. "Come in, come in, dear sister, I am so glad to see you. You will have some dinner with me. What will you have, blackberries, raspberries, salmon berries, or any other kind ? I have them all, so take your choice." She replies, "Oh, it doesu't matter what kind; serve me with any that you like." "Very well," returns he, and goes out and plncks, as he had seen her do, a spray of blackberry bush. He brings it into the house and sticks it in the ground and begins to dance and sing. His neighbours hear lim and say: "What's up with Raven? listen to him fooling." Cwot, too, was greatly amused at his antics, and endeavoured to hide her face in her hands to prevent his seeing her smiles. Raven sung and danced a long time, but the berry-spray bore no fruit nor made any growth. After awhile Cwot said to him, "Brother, stand aside and let me try. You don't seem to have the power." Raven was very glad to be relieved of his task. Cwot now sings her mystery song three times. It sounded to him like the song of the " berry-bird."

Immediately the bough began to grow and bloom and the fruit to appear and ripen. "There," said Cwot, " now eat your fill ; I don't want any." Raven greedily ate of the berries and took no notice of his crying, hungry children who also wanted some. While he was stuffing himself someone came to his door and said, "There's a man here who wants to see you; his name is Skwináuq, and he has a lot of halibut for you." "Oh dear," says Raven, "I'm in for it now. Where is he?" "Out on the water." Raven flies over to the man's house and goes inside. "Hello, brother," says the man, "you have got here, have you ? Come inside and sit down and I'll get you some dinner." So saying he took a halibut hook and removing one of the boards of his floor took up a splashing, live halibut. Raven looked on with greedy eyes and said to himself, "I'll kill this fellow and get all his supplies." Skwináuq placed the halibut before Raven, who ate greedily of it, pondering in his mind the while how he might dispose of Skwináuq. Said he to Skwináuq, "You have treated me very handsomely. Your fish was very fine. I should like to make sorne return to you. Let me carry you all round the country and show you many things you have never seen. Get on my back and make yourself easy. Don't be afraid of looking down. I'll see that you don't fall off."

Skwináuq got upon Raven's back, who flew into the air with him as high as the top of the highest mountain. The leight was so great that Skwináuq could scarcely see the land below him. "Now look down," said Raven, " and see what is below you. See that curions object just below?" Skwinanq was afraid at first to look below him, but Raven encouraged him, saying, " Don't be afriad, let go of my neck with one hand and look over the side." Skwinánq loosened his hold of Raven's neck and looked downwards. As lie did so Raven suddenly turned over 
in the air and east Skwináug into space, saying as he did so, "There, go down and see for yourself and stay there fol ever."

Raven now flew back to the Skwináuq's house, congratulating himself on the skilful manner in which he liad got rid of the fish-man. When le got into the house he took a line-hook as he had seen Skwináuq do, pulled up a plank, and then east it into the water. Instantly he felt a jerk upon the line and began to pull it up. He experienced great diffieulty in doing this. Said he, "There must be a very big fish on the hook." Pull as he might he could not bring it to the surface, it always managed to get under the planking. P'resently Raven kneeled down to look under the plank to see what was the matter. As his head eame near the water something elıtelied his hair and pulled him into the water, where be was speedily drowned.

This someone was Skwinćuq the fish-man who had fallen into the sea, and thus repaid Raven's treachery. When Raven was dead, Skwináuq let him come to the surface. The lifeless body floated away, drifting from spot to spot for a whole moon.

At the end of that period lie was thrown up by the waves on the beach. He lay in the sun for three days, at the end of which time be was brought back to life by the sun. When he was thoroughly himself again he related his adventure to his friend the Crane.

Day by day he sat upon a tree eracking jokes with all the other birds. Said he to them, "Take care not to get drowned in the fall of the year or you will never get alive again. Choose the Spring-time and then the sun will warm you to life again. It's great fun drowning and eoming back to life; you people should try it for yourselves." But no one seemed inclined to take his advice, and he soon betook himself to other parts.

\section{Story of SFmátl.}

When SEmátl reached the age of puberty, lis mother said to him, "I want you to undergo your KwEteéit and try and seeure yourself a Skwinoñét (spirit helper). He will help you avenge your father's death, who was killed by sueh and such persons." The youth went forth into the forest to keep his lonely vigil and laid himself down by the side of a great boulder.

One night the Spirit of the Boulder eame to him in his dreams and said, "Why are you sleeping here?" The youth answered, "Because I desire help to become a great runner and a brave warrior." Replied the spirit, "You ean't become such unless you skin the soles of your feet, and employ Wolf to to it for you."

"How shall I find Wolf?" questioned the youth. "You must first go to the mountain Tlāwulnóq; there you will see many bones and a great quantity of hair. That is the place for you to sleep in, and where you will find Wolf." In the morning he returns to his home and relates to his mother what had happened to him. Said he: "TsElQān (the Boulder Spirit) bade me seek the Wolf chief who lives at the foot of Tlīwulnóq, telling me that he would help me." 
His mother replies, "Very goorl, my son, llo as you have been bidden, but not yet awhile; wait ten days and in the meantime get me some kaillaltlp a certain bark), and I will make some strong medicine for you."

The youth procured the bark, and his mother beat it up very fine and made a drink from it. During the ten days he drinks the bark tea, and eats deer fat only. When the ten days were up she bade him set forth. Said she, "When you get to the mountain, follow the evening star and this will lead yon to the place yon seek." The youth set out, and following his mother's instruetions came in dne course to the mouth of a cave round about which lay many bones, and a great quantity of hair. Here he lay down and slept.

Wolf and his family came to the mouth of the cave, and the Wolf chief said, "What is that snoring that I hear? and where does this nice smell of deer fat and sweet breath come from? Ah, I see," he eontinued, as his eyes alighted upon the sleeping youth.

He and his wife now carry the young man into their cave aud then send for his children's instructor Squirrel. When Squirrel arrives lie is shown the semicouscious youth and told to scratch off the skin from the young man's feet. "Seratch," said Wolf, "till you lay bare the cords and sinews." This Squirrel did, and then Wolf took some pieces of deer sinew, of which he had a great store in the eave, ent out the sinews from the feet and legs of the. youth and replaced them with those of the deer. The young man's arms and back were trcated in like manner. When he had completed his task he called his youngest son to him and said, "See if you can lift up this young man? Now breathe your strong breath into lim."

The young Wolf did so and inflated the young man's chest with his wolf-breath. This revives him, and he becomes conscious again. Young Wolf now says to him, "Now you are fleet and strong. If you run for ten or twenty days you will never tire or get winded. I can run from one end of the island to the other before the tides can change. I have given you all my strength and wind. Now you should ask my father what is the best weapon to kill with." The youth did so, and received from the old Wolf his own Kwákwustan (skull-tapper) made from the horn of an Elk. "Your name henceforward is $\mathrm{K}$ wákwultüq. But if you want your powers to continue you must be careful not to lie with a woman when your Kwâkwusten is in the house or it will club you to death. First hide it in the mountain. When you sing your war-song say these words: "Ha! ha! ha! haha! úsa Kwâkwultūq.' (Ha! ha! ha! haha! I am Kwấkwultūq !) When you sing this song your enemies will lose their senses."

The youth remained with the wolves all that winter till the snow thawed; then he went back to his home. When he arrived he looked in and saw his mother crying and his uncle lying on the bed. The latter catching sight of him said to his sister: "What is that at the door? It has eyes and hair like an animal." The youth was cronching in the doorway holding his club. He now eries out, "Don't be afraid; I won't hurt yoll. My name is Kwákwultũq." But so sharp and piercing was his voice that both his mother and uncle eried ont in terror, and ho 
had great difficulty in making himself known to them and allaying their fear of hinn.

Now his father had been killed by some people who lived at Plumper's Pass, and he was determined to avenge his death. He questions his uncle as to the best way of getting there. "You must go by canoe," said the uncle. "Very good," replied the youth, "will you call your people to paddle me across." The uncle calls his slaves and the youth taught them his war-song to sing as they wont. In conrse of time they come to a place called Tselkalo, where lived the people who had killed his father. The people heard the singing of the paddlers and came out to see what it meant, and with them came the chief and his five strong sons. It was this chief who had killed the youth's father. His name was Qeyakwitsten, a noted slave maker. When Kwâkiwultūq's canoc was about 30 feet from the shore he sprang to lis feet, nttered his magic war-song, and leaped upon the shore. The mother of the five young men cries to them to run for the woods, but the words of Kwákwultūq's song benumbs their limbs and they remain helpless. He clubs them all to death and then returns home laden with booty.

Nobody can tonch or catch Kwákwultūq, so swift and active is he; and he caused much tronble and sorrow in the land. His death eventually came about in the following inanner. He was at war with some of the Clallam tribes and was making his usual great leaps when a branch in a lofty tree caught in one of the fur anklets upon his feet and so held him that he conld neither get up nor down, and the Clallam people shot him to death as he hung suspended by his anklet. When he was dead they tried to get him down, but were unable to do so. So they cut off his head and left the body hanging from the branch of the tree. Some time later his people came and burnt down the tree and recovered and carried off his body.

A Lek'oñéneñ Vocabulary.

Terms of Consanguinity and Affinity.

$\left.\begin{array}{c}\text { great-great-great-grandfather } \\ \Rightarrow ", ", \text { mother }\end{array}\right\}$ stsúpaiyuk.

$\left.\begin{array}{c}\text { greut-great-grandfather } \\ , " \quad \text { mother }\end{array}\right\}$ ókwiyuk.

great-grandfather

" $\quad$ mother $\}$ síla.

granlfather

"mother $\}$ tsímuk.

$\left.\begin{array}{l}\text { grandson } \\ \text { granddaugliter }\end{array}\right\}$ éñus. My grandson, ne éñus, my grandlaughter, sía nE éñus.

grandparents, swisíla.

grandchildren, ūñé̃̃us.

my son, nuñuna, te' suñ Etcetl.

my daughter, sknununa.

my family, nЕĩmũuna. 
my parents, ne télos.

mother, tan ; my mother, nE tan; addressed, ta.

father, man; my father, ne man; " ma.

$\left.\begin{array}{l}\text { mother's } \\ \text { father's }\end{array}\right\}$ roother, satc's.

mother's

father's $\}$ sister, satc's.

my uncles and aunts collctively, nF sīlate's. If parents dead, then called s'k Esätcatl.

my eldest brother

$\left." \quad, \quad \begin{array}{l}\text { sister } \\ , \quad \text { cousin }\end{array}\right\}$ nE céyotl.

my younger brother ne sáitcin. This term is used when speaker is prond of " sister $\}$ the relationship; if otherwise, he uses the term " cousin . sEtcatl.

These terms are used alike by boys and girls.

brother's

sister's $\}$ child, stékwen; collective form, stetékwen.

nephews and nieces (members of one family), nuqnetsalakwum. If immediate relative be dead, they are then called skwfmitcetl.

my eldest child, nE slutklétcetl.

my youngest child, nE sētcítcetl.

my father-in-law

my mother " $\} \mathrm{nE}$ sláletl.

$\left.\begin{array}{l}\text { my son-in-law } \\ \text { my daughter-in-law }\end{array}\right\} \mathrm{nE}$ stcútatl.

my step-father

my step-mother. $\}$ nE cQ-sál'wetl.

my step-son

$" \quad$ daughter $\} \mathrm{nE}$ s'ñañ.

my father's

" mother's $\}$ brother's wife, nE cQ-sate.

"father's

" mother's $\}$ sister's husband, nE co-satc.

wifc's $\left\{\begin{array}{l}\text { brothers and } \\ \text { male cousins }\end{array}\right\}$ slatl.

wife's $\left\{\begin{array}{l}\text { sisters and } \\ \text { female cousins }\end{array}\right\}$ sñutwon.

husband's $\left\{\begin{array}{l}\text { brothers and } \\ \text { malc cousins }\end{array}\right\}$ sñátwon.

husband's $\left\{\begin{array}{l}\text { sisters and } \\ \text { female consins }\end{array}\right\}$ cwál Fs.

wifc's relutions collectivcly, sElsslílletl. 
A man calls his wife's relations after her death by another term, viz., tefíiya. husband's relations, cQ-stcílatea.

my wife, $\mathrm{nE}$ sléni.

my husband, ne stálus.

widower $\}$ siyấten.

marvied man, tc'Etlúni = "belongs to v"oman."

" woman, tc'Ewéka = "belongs to man."

Corporeal Terms.

head, 'sk'wáñi.

faee, sFásis or s'isis.

crown of head, sk'tiilaúk.

back of hcad, tiiitcin.

forehead, skwúñus.

cheek, clēakwun.

iaw, s'k'lutcásun.

shull, tsāméuk.

hair, siä́ten.

beard, kwénesen.

hair of body, kwénEkwFs.

" " animals, skwóluken.

tooth, teinis.

tongue, téqsetl.

palate, slúkFn.

gums, slúkēnus.

nose, núlisen.

car, k'wólen.

eye, kúloñ.

eye-lashes, tlúpten.

eye-brows, sáñen.

pupil of eye, nEk'Hálos.

mouth, tsásin.

lips, slek'wásen.

upper-lip, 'slásum.

lower-lip, s'tletcasun.

throat, Hwóni En.

neck, Iwónsnetl.

breast ( female), skíma.

milk of the breast, "

breast (male), ts'uñEtl or ts'unElç.

baek, stíiskwktl. spine, tsúmōwitc.

loins, swōk $\cdot$.

stomach, k'las.

arm, tấlō.

shoulder, kōkwéuk'En.

forcarm, sâmeláqkn.

elbow, skwomkwolaqkn.

hand, sílis.

fingcrs, s'tcek ấlsis.

finger-nails, s'tcálsis.

thumb, sintlálasis, $c f$. sintla $=$ oldest.

thigh, sláletc.

leg, tl'k-úsin.

knee, sk•âkuñ.

lower leg, sampsen.

foot, snúkwetlsen.

instep, kúloñsen.

toes, s'tcequílsen.

toe-nails, s'tcecálsen.

bone, tsâm.

skin, kwólō (the whole skin=kwolōkwékwis).

heart, tsála.

blood, seátcen.

lungs, skákwa.

bowels, guk·é.

spinal cord, kléñun.

brain, smétsken.

liver, stâka.

fat, nos.

rib, lukwuq.

tail, stlupésnitc. 
Terms of the Prineipal Animals, ete.

elk, k'aiyêEte.

black. bear, s'tcítwun.

grizzly bear, k'waíctcin.

beaver, skelaú.

racoon, sqaík'wus.

squirrel, tsupsíasen.

flea, tātétlum.

lizard (rock) Qolqolawátcin (= "throwaway-tail"').

lizard (water), pêtcin.

snake, s'eátlka.

snail, k’aiâtlem.

hawk, иบи̃нáñul.

fish-hook, tcếoqtcuq.

robin, kwúskuq.

decr, sinaiyes.

panther, sinwôwa.

wolf, s'tek·aíyii.

mink, tcetcēák'un.

land otter, skấatl.

rat, k'wát'en.

louse, ñÉsuñ.

spider, tuktúkEin.

frog, skekánuq.

frog (young in the forest in autumn), wák•uk.

frog (in spring), wấkntl ("= croakiug").

grouse (blue), ñêt.

grouse (villow), sk wuts.

pigeon, humó.

blue-jay, tcitcéa.

snipe, skaíEks.

" skukaiya.

wren, tetúm.

raven, s'k'ūth́.

cagle, tcúskun.

, ske'tīánūq.

" k'wúlñāstก.

loon, snúk'wa.

canvas-back duck, Inllú́lawitl.

loon (big), swăkwurl. diver, qékwus.

" sqetés.

„ tluktītciñ.

crane, s'múk'wa.

seal, âsuq.

porpoise, kwắnet.

sea-lion, ces.

whale, kwknis.

sea-trout, stEánis.

halibut, săteq.

cod (black), éyit.

" (red $)$, tuk tuk:

" (rock), éasésin.

, tom, ts'âauq.

herring, slấñit.

smelt, kwắtlis.

flat-fish, k:āk:au.

ling-fisher, tsetcéla.

wood-pecker, tséekut.

$$
\text { , tsútuñ. }
$$

owl (large), tcitctúñuq.

"(small)s'pupulkwētza (= "ghosts").

crow, sk'ōk'wăta.

goose, tlâk kw EqEn.

mallard, tínuksEn.

brant, Hwấauk; sHulHultc.

swan, swôk En.

luek, stúmetc.

" tsauitcäqEı.

" kwấkweloq.

„ aúina.

" sEsaríq.

sca-gull, kúni.

fur-seal, tsaiya.

sect-otter, túmas.

salmon (spring), kwétcin.

" (sock-cye), súkai.

" (eohoc), k'Étcuks.

" (dog), kwálōq.

" (hump-back), húnEn.

" (stecl-head), s'jank.uni. 
flounder, pówi.

whiting, skwēmus.

bull-head (large), skwénetl.

(small), skwaíȳūwitc.

devil-fish, skếnuk'u, tháaiyuk:

$c r a b$, átcuq.

elam (largc), swäm. elan (medium), sấqwa.

" (small), s'k*otlāaí.

cocklc, stlklấum.

mussel, tlaúkkum.

sea-cucumber, sékōt.

sea-eggs (large,) qékwa.

" (small, ) skwétsē.

Torms of Principal Berries and Roots eaten by the LEkúñEn.

strawberry, tếluk:

salmonberry, kléla.

Ulackbcrry, skweláliñuq.

salalberry, tíka.

gooscberry, tiimūq.

hauthornber"y, máaitciñ.

sour grass, temása.

wild parsnip, tláQEel.

lily bulb, sákwitem.

" " tleliun.

fern-root (Pteris aquilina), skwaiū q.

white-elover root, ts'ítcin.

"sōpalali" berry, sháisum.

wild chcrry, stsákoun. whortleberry (bluc), âsa.

$" \quad(r e d)$, pípue.

raspbcary (black), s'k'wáma.

crab-apple, káauq.

"ground-apple," k'lćk'wun.

"kamass" root, kwetlál.

carrot (wild), săkwuk.

onion " k'óqkwaiitc.

tulip bulb, tsúlok:

wild rhubarb, sauk, yála.

wild eelery, skutwaiyas. The seed of

this plant was used for making a

kind of tea.

\section{General Glossary of the Commoner Words.}

$a b l c, c a n$, hoñ.

I can, hoñ-sEı kō.

above, sítlunũ.

aeross, täkwen.

adopt, skwonétlun.

afternoon, hai tauq k'êlet.

ugain, kwlát.

aid, $h c_{p}$, kwEniiñs.

alder-tree, skwoñetltc.

all, muk $\cdot$.

rluoys, òyá.

anchor, k'seuálen.

anger; tetaíyuk.

animal (generie), tElìiš̌lanūo.

another, kiriit.

give me unother, anaitce keliit. answer to, nüqtâllkun.

anybody, muk.u san.

apple (crab), káauq.

apple-trec, kāqwiltc.

ashamed, qaíaqa.

I am ashamed, qaíaqa-sEn.

$a s k$, to, tc'tấtce.

ash.cs, s'tcekōsála.

aul, 'sutlkwéñns.

are, skwōkúñ.

baul, sqūs.

bail, to, kwélest.

bailer, $\alpha$, ts'añten.

brit, î̀álñuñ.

bake, to, tálak.

bork of trce, tckli. 
bark, to, wewás.

he is barking, wÉ'sEla.

basket, mehói.

" (large), súmeten.

" (packing), tlunas.

becıch, sásau.

beat, to, kंōtcátiñ.

beautiful, êi.

bed, ewámut.

beg, to, ńña.

below, klätcitl.

" down strean, $\mathrm{k} \cdot \mathrm{wok}^{\cdot \mathrm{u}}$.

belt, swiåunten.

bend, to (stick), EsnáñEtl.

bent, Eskwáseti, spápi.

bcrry, 'sEtiténẼ̃.

big, lav'ge, teuk.

billow, wave, yálateip.

bite, to, ts'uñut.

bitter, sáqEn.

black, nuk'êEq.

blackberry, skwuláluñoq.

blankct, tlskēt.

blccding, súteEñ.

blind, aúwina c'kwinátl.

blow, to, páQet ; blow it! pāQEt-teE !

blue, tsáwoñ.

blush, to, nukutséles; he is blushing, nukulséles kō.

boil, to, kwúlus; the water is boiling, tlapáknñ.

bold, brave, Qstcä́nukwoñ.

bore, to, sluk'ut.

borer, $a$, ckulteênutl.

borrow, to, áiyil.

bottle (made from dog-fish gut), sÉsa.

bou, to, nEkwásiñ.

bow, $a$, cwunüiten.

box, klaíakus.

boy, stlétlätlkus ; youth, swéakātl.

braid, to, tuñsåñnñ.

branch, tsustîisis.

brcali, to, tuk.u. breaking, tuk'tuket; brcak it up ! tuk.tuk'Et-teE !

bright, kaíqumañ.

bring, unaúq; bring it here! umaúqsōo-atlá:

brush, $a$, cwopúlken.

burn, to, teuk $\cdot \bar{u}$.

bur'y, to, teinit.

bush, Ecếcits.

call, to, kwiinis.

canoc, snūkwetl.

camp, kúlñuñ.

carry, to, ìkwinat.

carve, to, nutkwênus; he is carving

HusHut-kō.

catch, to, kwinet ; catch it ! kwínEtce !

ccdar, q’pái.

change, to, aiyúkut.

charcoal, tcésut.

chew, to, ñíakwut.

chief, notable, hếwus, silísiäm.

child, stlettlutlketl.

children, stlālētlutlketl.

cholie, to (from eating), t'kwếnatl.

$"$ "(from external pressure)

teuptlnăleten.

chop, to, k’ok'wńmela.

clay, sēyúk.

climb, to, cÉluñ.

cloud (white), Esíten.

coffin, sták.oni.

cold, stsátleñ.

$\operatorname{comb}$, to, tecēkoñ.

$c 0 m b, a$, tlsíñeñ.

come, to, ená.

I am:coming, ō yEená-sen.

corpse, $\mathrm{kw}$ tllesnánite.

cotton-wood-tree, tcÉnawetlp.

crab-trce, kekQitltc.

crab-apple, kauq.

cry, to, Qāñ.

curvcnt, cQoñáleken.

cut, to, klësut ; cut it, klēsut-sōq. 
daily, nok" - skwíteil; ad litt. "every day," "all the days."

dance, to, k'waiéluc.

damp, såsăsqoñ.

lark, tlītc.

darling, dear, nícoōskwī.

daybreak, skítcalïin.

daylight, kw'tl-kwátcil.

day, skwátcil.

dead, kwai; just dead, kw'tl k'umetln Etl;

sometime dead, sk'wäkwai.

deaf, sk'wolî́n.

deep, klute.

deer-hide, kwÉlō-Esméis.

desire, wish for, to, stle.

diffeult (to do), k'lè kō.

different, nèts.

dig, to, séakweñetl.

dim, coonấwus.

divty, keléma. Collective form as

applied to people, kEkEléma.

disappear, to, ósúqweal.

dish (long wooden ones), kw'sáles.

" (small ones), emēman lásen.

" (largc ones), tcek lásen.

disappoint, to, mÉluk.

you disappointed me, méluk Esōe kō. distribute, to, tlétut.

dive, to, núkuñ.

dizzy, giddy, sćlk ‘uñ.

door, sáatl.

down, skaíes.

drag, to, Qưkwkt.

dream, to, skElkelásEn.

I cm dreaming, nE-skelkelásen.

drecem, to (a nuystie dream), skwinấñet. drop, to, kwiskwau.

drown, to, kuss; he is drowned, Es kEsīkuss.

drum (mad' from skin), kwélō-kańit.

" " " board, kwaniitiñ.

erech, nátsià.

earth, kōqwelnṇ̃, tuñuฯ. eat, to, étleu; lee is eating, tī etlen. easy, lếluk; it is easy, o lếluk kō.

$c c h o$, sïmúñ̃Ez.

cdaly, k•aíaquñ.

clder-tree (red-berry), tsêwuk:

, (purple-berry), tsékōk.

cnemy, cEmän.

enough, kw'tlätlum or Estlatlum.

evening, tấñEn.

fall, to, tcäk.

far, léla.

fat, grease, nos.

„ stout, nōl.

feel, to, tlīpst.

fight, to, kwêwuntel.

file, $a$, Ectākus (= grind-stone).

fill, to, letsút.

find, to, kwÉnuq.

finish, to, cuk:

fir (red), tsecái.

fir, skímiyoks.

fire, stcókūsa ; burnt, teuk.

fire-stones, kwentálus.

fre-place, stcókōsa-ála.

fire-wood, ctciitl.

fish, stluknáñiñ.

fish-bone, sîm, utl stluknáñif.

fishermun, ō yớsyE stluknáñiñ.

flame, Qktákuñ.

flat, Estluk'unok-u.

flesh, sléuk:

flower, skwâkEñ.

float, to, pEpákuñ.

fog, spägon.

follow, to, tcīsálakuñ.

food, skếtlen.

freeze, to, tcioales; the water is frozen,

pēwitkĩ.

fun, àyósiñ.

gamble, to, nūkslkhấlenı.

ghost, spilkwétsa.

yirl, slinkteatl.

yivls, slinlinatcīlatl. 
give, to, áñust.

glad, héalauk.

I am glad, héalanksEn.

good, êi.

good-bye, haikńtea, haiý̛ikō.

grass, sq Esái.

great, big, teuk:

greedy, nekélewutl.

green, nkkwäi.

groan, to, unquset.

grow, to, tsésiñ.

grumble, to, tetátuk:

guide, to, kwếoq.

gum, pitch, smâmitc.

hail, tsutēméleEn.

handsome (of faes), nōqwaíyis.

harl, $\mathrm{k} \cdot \mathrm{lEq}$.

hark, lıāalañiñ-tei (tci, imperative $\operatorname{sinffix)}$.

hat, stckssak'; hats, stcetcēsauk:

$h e$, tsäa tsäa ō nētl.

hear", to, aläir En.

I hear you, ò aläñen-sEn ko.

heary, 'sEl.

$h e l p$, to, kwEná⿱ñ.Es.

hide, to, kwâles.

I will hide, kwálles-sEn-sa.

hill, Espâpuk.

hold, to, kwinát.

hole (round), sutlk·u.

" split, estcấketl.

hollow (open), estukoñ.

" closed, cūwéwon.

hook ( $g a$ aff), tlēkwun.

home (house), áluñ.

horn, ts'ésten.

hot, kwáles.

house, áluñ : small house, ãâluñ.

howl, to, wósels.

huckleberry, skwôtcis, pépœō.

hunt, to, ámEna.

hunter, umámFna. .

husband, stâlus, addressed, nau.
$I$, tĩa ńsa.

iee, sếma, slêloq,

infant, skákāla, coll. skalákala.

itch, kwulkwólnñ.

jump, to, Qētuñ.

leep, to, unskwáto.

kettle (wooden), súña.

„ (basket), ts'úmten.

liss, to, nu kwáset.

kneel, to, sukuitlkañ.

knife, cêpEn.

know, to, q'tcēt.

lake, hấtca.

language, ckwElten.

large, big, tenk:

laugh, to, nEnćyuñ.

leaf, 'sátstla.

lend, to, fiyel.

lie, to, nuqkaíyuqkun.

liee, ñúsEu.

lick, to, tlấm Et.

lie down, to, skwấset.

life, únewili.

lift, to, sấat.

light (of lay), staitī.

lightning, skwf́nkla utl sqōkwās

(="glance" of the thunder-bird).

little, tletlōtla.

live, to, cwili.

$\log$, kw'tlấi.

long, k'lâkkut.

lose, to, qēl.

loud, tcekúken.

man, swēka ; men, sōwékka.

maiden, k’áñi, tcislítni.

maidens, k’aláñi, tcrslensáni.

maple-tree, stláEtltc.

married man, te'tlấni.

married woman, tc'wêtka.

mark, to, qElḱla.

mat (bed), slaúwin.

mat (seat), sil Ewátcin.

me, tfa ísa. 
mean, núktli.

meat, sléuk:

mèdicine, stấleñuq.

meet, to, núktcimost.

melt, to, teáqwet; melt it yourself, tcấqwet-skwétc.

mend, to, núqEput.

middle of night, tãq-nuq-net.

middle of day, tāq-kélet.

mind, quitenEñ.

mine, I tía Enskwa, this is mine.

Enskwa $\}$ aúa sniskwa, it's not mine.

mistake, to, melmálluñ.

mix, to, malmélite.

moecasin, slíkcin.

moon, 'skalte.

morning, kwetcíl.

morning-star, kwetcíl lálus.

mountain, sísitl-sñấnyit ( = high rocks). move, to, tcänis.

" to, one's body, kwéEkset.

much, many, ñuñ.

murder, to, k'ōEtcíla.

murderer, kwilêūs.

naked, Etlâtluk; I am naked, Etlátluk-

SEll.

name, snī.

narrow, Qéąōoai.

neair, stásetl.

needle, tcátsen.

needy, poor, estáses.

net, swéltun.

night, snät.

no, aúa.

not, aúa aúank.

none, arian $\mathrm{E}$.

noon, taik skwâtcil.

now, ō̄n, tía kō qoñ.

nut (hazel), k'wupaúq.

" (oak), sisiákwa.

old, kw'stlalōq, coll. kw'stlilalōq. orphan, kwäniñ, coll. kwElấniñ.

outside, Esáketl (= out of doors). outside, skb́lawutl (with reference to objects).

paddle, oânit.

pail, skwâten.

pain, qấtlitl.

paint, tímutl.

paint, to, qúlet; paint it, qúlet-tci.

pass, to, teīlâú.

path, trail, sáiyetlsetl.

"road, sâtl.

paw, sális (= hand).

pay, to, núnatet'.

peel, to (apples, ete.), cpálest.

" " (trees), sk'wékwust.

peep, to (through a hole), tcitkásin.

", " (round an object), nukwilásin.

people, estáliñoq.

perhaps, ēwátca ; per.haps $I$ 'll go, ēwátca

úsōīỹ̄-sEn-sa.

play, to, yêyásin.

prick, to, tute; don't prich me, aúa tute noñ Es.

proud, Esmátsen.

push, to, tcấnit.

quarrel, to, kwElnû́El.

quiet, to be, sấmoq; be quiet! súmoqtei!

race, to, owwátel, ótal ; foot-race, kwañi-'

ñut; I will raee you, kwáñiñut-sEn-

sa. In the verbal form it will be

seen that the accent is thrown forward.

raw, qaits.

recognize, to, ópetit; 1 recognized hım, óptitit-sEn-tsii.

red, nEsúl $\bullet$ u.

red hot, neQailuñ.

rest, to, kākūiñ ; rest! kākūñtci !

remember, to, óhak'u.

return, to, nukEyḱlkun.

revive, to, hentcấwiyes.

ring, $\alpha$, stêti.

ripe, k'wol ; it's ripe, kw'tl k'wol. 
river, stúclō.

roast, to, k’wóluñ.

" "(roots in ashes), stáluk.

rob, to, kEnêtuñ.

robber, kấnkun.

roof, sláletuq.

root, kwotsúñ.

rope, line, tcâtcettl (cedar), kwāñ (kelp).

rose, kúlok.

round (long things), cilkwêos.

" (flat "), usīyăluk:.

$r u b$, to, Qéakwut; I am rubbing it,

o-Qćakwut-sEn-ko.

run, to, kwàuiñEt.

sail, pōeúnuñ.

same, as, like, Qknáñ; same as this, QEnáñ tlī.

sand, pökwútcin ; gravel, ts'qait.

say, to, yesấs ; tell me, y Esấstci.

seald, to, kwäs.

seold, to, kwáliñut.

serape, to (carrots, ete.), Equíkst.

scrape, to (round objects), Eqấlist.

serateh, to, éaqEt.

scrcam, to, kōkwấtcin.

search, to, saíyukt'.

sea, k'tlátlse.

seed, plant, to, tcinéñetl.

see, to, k'wónet (different from kwúnet, to take).

send, to, set.

sew, to, tcäiyits.

shadow, kēakenấten.

shake, to, kwếEqt.

shallow, cí́cum.

shame, qaíaq ; you ought to be ashamed

of yourself, Eusqētsel wā.

shaman, cwonám.

sharp (edge), aiy Es ; (point), aiy Estíksin. sharpen, to (point), cpúkste (edge), tekấqEt.

shoot, tlenakut; it's shot, Estlenk ${ }^{u}$.

short, tcetcéyutl. shout, to, kwätcuñ.

show, to, k'unit; show it to me, k'unittíñnoQ.

shut, to, Q'tskut.

sick, skáttleul; I am sick, Eskíttetl-sEn.

sight, skwenfla (= glanee, gleam of the

eye).

sing, to, stếlEm.

singing, tetêl Em.

$\operatorname{sink}$, to, k'lätcéluñ.

sit, to, úmut ; sit down, límut-tei.

sky, kwấteil.

slap, to, t]ákwut.

slave, stóñetloñ.

sleep to, étut ; I feel slecpy, etútuñ-sFu.

slide, to, sqwếnetEñ.

split, to, qaítun.

slow, âtcein.

smart, quick, ноñноñ, lively= sqaiyúes.

smcll, to, laâkwenūq.

smell, odor, laáuik.

smother, to, tuk ${ }^{\mathrm{u}}$.

smile, to, nuqnenếyuñus.

smoke, púliōñ.

snail, tluqwoméwus (=slippery body).

sneeze, hấsiñ.

snore, tletákwuñ.

he is snoring, tletákwuñ ko.

snow, ñấlia ; it is snowing, tcíyuk.

snow-shoes, tcīekwimcin.

soak, to, stállkkai.

soft, limp, nēákwom.

" (to touch), kwiil.

song, stēluñ.

soon, túiātl.

soot, kwaiéteup.

sore, a, skwâkwutl; I um sore, kítketlsen.

soup, slāp'.

sour, tcấ@uñ.

sparon, kÉluq.

sparks, tlelétsiñ.

speak, to, kwEl.

spit, to, tcūQátlsa. 
split, to, teuq.

spoil, kulkéla; don't spoil it, aúa-son.

kulkulélet.

spoon, qaálō (horn), tlấpen (wooden).

spring of water, metăkō, mấtcō.

squeeze, to (with hand), tcếput.

" hug, to, tcepást.

" to (betweeen logs), kstcúnz.

stand, tsétliñ.

standing, sktsêtlin.

star, tetaúisina.

starve, to, tl'tcut.

steal, to, kīn.

steam, vapor, câlaQuñ.

step, to (over something), tEqấkwus.

" "tcinstiniñ.

stick, to (in), ñēEkut.

$"$ "(to $)$, tluk $\cdot \mathbf{u}$.

sticky, tluk $\cdot \mathrm{utluk}^{\cdot \mathrm{u}}$.

stone, sñáñit.

stoney, sñalánit (= many stones).

stoop, to, kEpấsiñ.

stop, to Énūq; stop hin ! Énuqtūq!

straight, Estcâiiyen.

strap, suñâten (=packing instrument).

stream, a, státāo (=dim. of river),

kwáiteñ.

strength, power, tzantckwámkwum.

strike, to, ctcut.

strong, kwámkwum.

stump, ts'áletc.

stumble, to, tlēuksm.

summer, teiñ kwélis.

spring, tciñ kwókwelos.

suck, to, skwátiñ.

sun, skōkw Él.

sun-beam, sqúnas tc' skōkwt́l (= "legs

of the sun.")

sun-rise, kwān (=coming over edge of

horizon).

sun-set, Q'tuk (= fall down).

swallow, to, núket.

succat, to, tcákuñ. swear, to, kuséniñ.

swcll, to, nuksáletenl.

sueep, to, équt.

sweet, sákuñ.

swim, to, tuñóñ.

swimming, ètuñón.

swift, quick, Qoñ.

swing, to, kétātuñ.

take, to, kwinit ; take it, kwinit-tci.

tall, tlāk'ut.

tane, $\mathrm{k} \cdot \mathrm{wál} l \mathrm{k} \cdot \mathrm{w} \mathrm{El}$.

taste, to, tät ; taste it, tät-tci.

teach, to, Ekwâtcetl.

tear, to (eloth), súket; don't tear it, aúa-soe súket.

tear (lacrima), ckos.

tell, to, yesás.

that, tsii.

thaw, to, tcauq; it's thawing now, ètcauq Qoñ.

the, $\mathrm{tE}$ (masc.), $\mathrm{sE}$ (fem.).

thee, tz núkwa (masc.), sE nukwa (fem.).

there, lā, tôlō.

thick, tc'tlut.

thief, kánkEn.

thin, tcitcemél (with reference to material).

thin, Eskwúmoq (with reference to persons).

this, tlā (referring to objects other than human).

this, tía (masc.), sía (fem.), also used with inanimate oljects.

thunder, sQōkQás or sqōkwás (= thunder bird).

throw away, to, Qéltuq.

throw, to, ts'tsälá.

tickle, to, sépteñ.

tie, to, kaíakwet.

tived, stcếkwus.

to-day, ánuk.

to-morrow, kō kwêtcil.

toreh, ñāk. 
touch, to, Esêstuq; don't touch it, aúasōQ Eséstuq.

track, trail, huñañÉnz.

trap (for animals), Hícen.

" ( fish), skeláliñōq.

tremble, to (from fear), sâisi.

" , (from cold), teÉnuñ.

try, to, táat.

I will try, táat-sen-sa.

turn, to (round), tcilä́niset.

" (over), tcilóset.

twilight, skaflet.

twist, to, qElútcet.

ugly, sqās.

uncover, to, klewēst.

understand, know, to, ōqtcết.

undress, to, tlâkwuñ.

village, túñuq (=earth, land), tía na

túñuq, this is my country.

voice, skwálten.

vomit, to, tcáat.

wade, to, séaquñ.

wait, to, nukwaieśs, tswiskấi, kấi ; he is waiting, ō ñukwātēẽ Es kô.

wake up, to, qútceset.

walk, to, stuñ.

wall, tíñnen.

war, qếluq.

warm, hot, kwáles.

wart, 'stcúpqon.

wash, to (oneself), sákoñ.

watch, QēyElós.

water, kwā.

wave (small), hấiyeluk.

" '(billow), yâletcup.

we, te tlñiñetl.

weave, to, ts'äkkñ. wedge, kwaitEq (maul, for driving= ctétlsis).

weep, to, suk'unáles.

whisper, to, saúkuñ.

whistle, to, cāp't'.

$w h y$ ? nētl kw's ustáñut ?

why do you whistle? nētl kw's ustẫũ uncūcāp't'.

white, puk:

who, sañ.

wide, tl'k•ut.

widow, sĩyáten.

vidower, säsīyáten.

wife, stấles; when addressed by husband,

nau.

willow tree, sqwäléetltc.

win, to, netl'wónuk.

wind, 'sp'wéla.

". to, k·Élakwist.

ving, stlekál.

vink, to, teEpálesẽ̃.

vinter, tciñ sátliñ.

wipe, to, âtcet.

witch, sīalia.

with, aisūwa, kwacínisa.

I'll go with you, yE sEn sa ai súwa.

woman, sláni.

wood, stcatl.

wor\% to, tcē; I am worling, tcē Es-sEn.

$I$ have been working, $\bar{o}$ tee $\mathrm{yE}$ sEn kō. wring, to, tcếsut.

yawn, to, wákus.

year, netsa (=one) stcelấn Eñ.

yellow, nukatê.

yes, háa.

yesterday, tcilaketl.

you, te nukwélia.

\section{The Kauítsen on Istand Halkōmélem.}

The following notes and myths on the Kauftsen or Island Halkōmélem I gathered from Thomas James, an intelligent native of this division.

Socially the Kauitsfn have more in common with the neighbouring island tribes than with their brethren of the mainland. Linguistically regarded, however, 
the original unity of the two divisions is very elearly bronght out. Indeed, I may say that it was a somree of much gratifieation to me to find that Thomas James could follow and understand my native texts of the River Halkōmélem without the slightest diffienlty. The chief distinetion between the two divisions is in the presenee of a verbal partiele "pa" in the island specch which is totally absent from that of the mainland; and in the mode of utterance. The island speeeh is sharp, brisk and preeise, while that of the mainland is slow and drawling to slovenliness. It is this difference in the mode of ntterance that makes the speech of the two divisions seem more distinct than it really is. The vocabulary differenees do not amount to ten per cent. of the words, and the praetieal identity of the two forms is admirably brought ont in the little story which I have written in the two dialects in parallel columns below.

The first Kau'tsen was "tEn skwail," that is, "heaven-born." His name was Qultênten, the name of the second, also "ten skwail," was Stétsen. From these two men and their wives all the Kauitsen people are supposed to be deseended.

The story runs thus: In the begimning Qultkmten and StÉtsen lived on Sháwnigan Lake in a house by themselves. For wives they had carved two female figures ont of wood, and had partly made a basket, leaving it to be finished by the women.

Now it happened at this time that two "tEn skwail" women lived alone without husbands at Sooke Harbour. By some means the knowledge of the two men eame to the two women and they determined to eross the mountain and seek the dwelling of the two men. They perceived the house before they came to it by the smoke ascending from the fire-place. When they reached the dwelling Qultinten and his companion were from home. The women looked round the house and saw the two wooden figures. These they smashed into pieces and threw them into the fire. They then took up the unfinished basket and completed it. Then they hid thenselves to await the arrival of the men. Qultemten shortly after came in and at once perceived the finished basket and was well pleased. "The next thing l want you to do now is to talk," said he to the figures which he thought were present. He now looks about for them and presently sees their charred remains in the ashes. Presently Stétsen eomes home, and he tells him of the finished basket and the loss of their wives. The two men are sorry and grieve. At this the two real women eome forward and show themselves. The men bid them welcome, saying "We are very glad to see you; we are very lonely. You shall be our wives." From this union thus brought about, sprang the Kauitsen people, and peaee and friendship have always existed between the Sooke and the Kauitssn.

There seems to be an elcment of real history in this tradition. It is possible that the Kanitsen are eomparatively recent comers on the island. The praetieal identity of their speech with that of the river tribes of the mainland suggests that they eannot have been long separated from the nainland Halkōmélem; and it may be that a small band of men from the Fraser Delta drifted or otherwise found their way to the island and intermarried with the Sooke and settled there. 
Qultfimten is said to have named his children by bestowing modified forms of lis own name upon them, thus:-

Masculine Forms.

Qultēmit.

Kwelấsten.

Kwelsitstin.

Swelâmskt.

Sîn̂m.

\author{
Feminine Forms. \\ Qultēmtknăat. \\ Qultémēy E. \\ Kwelsēmīya. \\ Siâmtenât.
}

These names are "sēwanatl snä," that is "sīwēn" names, mystery names. Their significance is now lost.

Common people's names were mostly derived from nick-names.

The following are the list of villages or settlements of the Kauitsen as given me by Thomas James.

\begin{tabular}{|c|c|c|c|c|c|}
\hline Villages. & & First Chiefs. \\
\hline 1. Tskmếnus ... & $\ldots$ & $\ldots$ & $\cdots$ & $\ldots$ & 一 \\
\hline 2. TlumtlúmElets & $\ldots$ & $\ldots$ & $\ldots$ & $\ldots$ & SQāsílen. \\
\hline 3. Kwákqonets & $\ldots$ & $\ldots$ & $\ldots$ & $\ldots$ & 一 \\
\hline 4. Tátke & $\ldots$ & $\ldots$ & $\ldots$ & $\ldots$ & TsắsīetEn. \\
\hline 5. Kw'säsínus & $\ldots$ & $\ldots$ & $\ldots$ & $\ldots$ & Ciấk Eset. \\
\hline 6. HúuntsEn ... & $\ldots$ & $\ldots$ & $\ldots$ & $\ldots$ & - \\
\hline 7. Qulkwesála & $\ldots$ & $\ldots$ & $\ldots$ & $\ldots$ & 一 \\
\hline \multicolumn{4}{|c|}{ 8. S'âmena (older settlement, Sâtlām) } & $\ldots$ & LāmEqÉsEt. \\
\hline 9. Kwắmtên... & $\ldots$ & $\ldots$ & $\ldots$ & $\ldots$ & Qultemten. \\
\hline 10. KwamēyêkEn. & $\ldots$ & $\ldots$ & $\ldots$ & $\ldots$ & - \\
\hline 11. Hainípsen ... & $\ldots$ & $\ldots$ & $\ldots$ & $\ldots$ & - \\
\hline 12. Kwấtkum ... & ... & $\cdots$ & $\ldots$ & $\ldots$ & 一 \\
\hline 13. Sétsmelkun & $\ldots$ & $\ldots$ & $\ldots$ & $\cdots$ & - \\
\hline
\end{tabular}

Forty-five years ago the Kauitsen uumbered 5,005 sonls, aceording to a census taken by the missionary in charge. To-day they do not exceed 800 .

\section{Cowitchin Traditions of a great Flood and Earthquake.}

The Kauitsen proper of Vanconver Island derive their divisional name from the chief mountains of their habitat. They believe that it was here they came together after the great Flood. They say that before the Flood everybody used to dream of its coming. Some of the people heard a voice saying, "Build a big raft which will hold all your family and friends." 'This they set about doing. They took two large eanoes and laid a planking across from one to the other, and on this construeted a house in which they stored all their belongings and much dried fish and other food. They also made a long cedar rope and attached it to a great stone on top of the mountain; they made a hole in this stone by which to fasten the rope, 
and this stone they say may be seen on the mountain to this day. When this raft was finished a noise like the report of a great cannon was heard and the river begain to rise rapidly. There was no rain at all. As the water rose they pulled on their rope and rose with it till the top of the mountain was reached. Then the waters slackened. This condition of things lasted about one moon and then the water level began to iall, leaving the floating trees and logs on the upper parts of the mountain, where they can be seen to this day. When the flood had subsided and let their raft down again it was found that all the animals had been drowned and that the fish had died; there was nothing for the people to eat but the bodies of the drowned animals or the floating fish. A great number of those saved from the flood now died from a sickness cansed by eating the dead flesh. At last when the ground was dry the women and children set to work to dig wild carrots. From these they made a melicine which cured their sickness, and they recovered, and in time became a great tribe again.

In the days before the white man there was a great earthquake. It began about the middle of one night and continued about twenty hours, when it ceased. It was so severe that it made all the people sick, threw down their houses and brought great masses of rock down from the monatains. One village was eompletely buried beneath a land-slide. It was a very terrible experience, the people could neither stand nor sit for the extreme motion of the earth. The old people took their stone pestle hammers one in each hand and pounded the ground with them, chanting a song to the spirit of the earth as they did so. They bade everybody do the same, and a little time after the shocks ceased. It is more than possible that these two traditions have a basis of substantial fact.

\section{HaLkóMëLem Texts.}

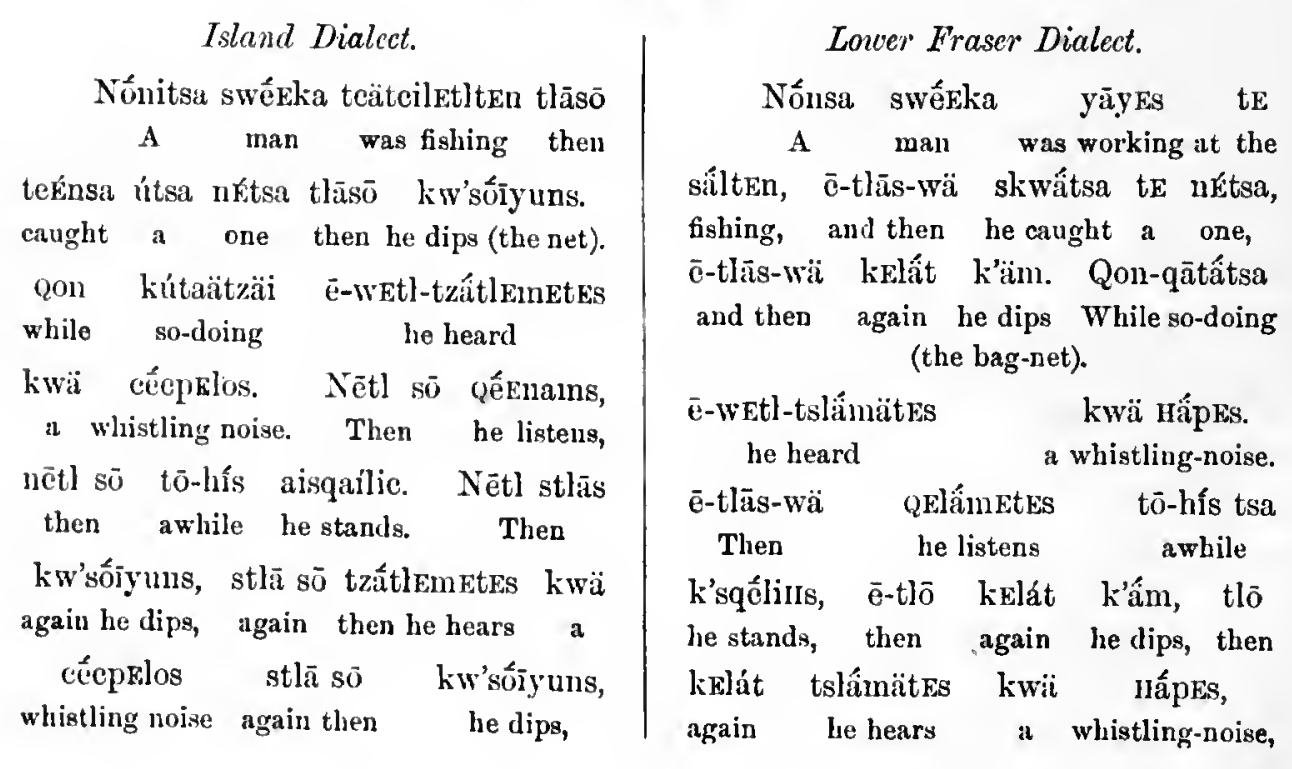


kla wutl kelát tzấtlemetes kwä then again he hears a

cécpelos ē-yātl-nEs tElnūqs kw's whistling noise then he knew that nètls te cúnses céeptos.

it was the game (which had been) whistling.

Nētl sō kwónets te uq̣sếmten, nētl sō Then he took the net, then Qōomesắstes nētl sō tákus. he folded it up then homewards. Nētl ne sō Qōníns te cūwális. Then he reached the parents-lis. Nētl sō kwals: "Namtsen tấntīla, Then he said: "Go I away, tōhístóa émē tsen QEảlEm." Nē au shortly come I back." Then tsấwin kwe slếuk, netl sesō laaíya, lie tonk some food, then he set ont, nētl sō haiyas-kwaiyisit. ō yástse then he sought his guardian spirit. always kw'sō sEsīs te cwímut te menas. then kept re:tly the bed the son-their. Qusénks tl'kalts aiyēmē luunt. Four moons he came bome.

Netl sō yetatekūs nētl sō kwénets Then he was coming then he took home.

tE sákōm nētl sō tlâkuts nē the cedar-bark then he tied npon te kwÉles, nētl so kéakusuts, snat the belly-his then bound it up, night kw'swetl humúmets, âú swewé $\mathrm{SE}$ it was when he arrived she was awake his home,

sEáilōq, nètl sō qiets tE stálus, mother, theu she woke the liusband-her, nētl sō p'tútunxts: "Nūâä ” “ánsii.” then they ask: "It is that "It is I." you ?"

Nētl sō nans neúmistọis te Then they go to put-him-they-to the ē-tlō kelát k'äm, tlō kelat Then again he dips, then again tslámuites kwä Hâpes. e-tlas-wä he hears a whistling-noise. Then he tulnues kw'stlas te cqEnses knew that it was the game nī-HấHapes, tlīs-wäi kwénits te (which) had been then he took the whisthing,

swéltens, ē-tlīs-wii lumlúmits. net-his, then he-folded-it-up. č-tlās-wä nEms tāk ${ }^{\bullet} u_{Q}, \quad \bar{e}$-tlās-wä then he went home, then gunins tE eōwális è-tlās-wä he reached the parents his then kwäls : Nem-tseu èyilisála, tōhístsa he said : Go I away, shortly ēmē tsen k'onsit. ē-tlīs-Es-wä kwknits come I back. And then he took tE ämímenslēuk $\bullet$. è-tlīs-wï nEms, a little food. Then he-set-out, $\bar{e}$-tlās-Es-wii kwaiissts, wiấtl-tsa and then he sought his Always guardian spirit.

kw's wii-e staugs te skyél th they kept ready the parents the eoqks te mEnas. rïrîiskn tl'kelts bed-his the son-their. Four moons émē QEximst, kw'ses tsa mä-tlā-mē he came home, while lie was coming

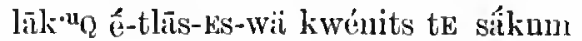
home then he took the codar-bark c-tlas-Fs-wii tlakuts ne te kwÉles, then he tied it upon the belly-his, é-thans-es-wii kêkuts te kweles. then he bound the belly-his. Snat tsa kwa k'swetl-tấtcels QEấmet. Night it was when he arrived home. ē-wīewewī sE síEl, é-tlās-Es-wii She was awake his mother, then Qēts te swếakus, ć-tlās-Es-wä she woke the husband-her, then p’tünits: "Nốa?” "Énsa." ask they : "Is that you ?" "It is I." é-tlīis-Es-wii nelus námistors te Then they go they put him to the 
Wh́mut, ē-tō-hís ēméaknp . E bed, presently assembled together a kuq nistémōq, nētl sō kwáles multitude of people, then spake tE seláloq: "kwếtla hanwấlEmatla. the old people: "Let us see perform you

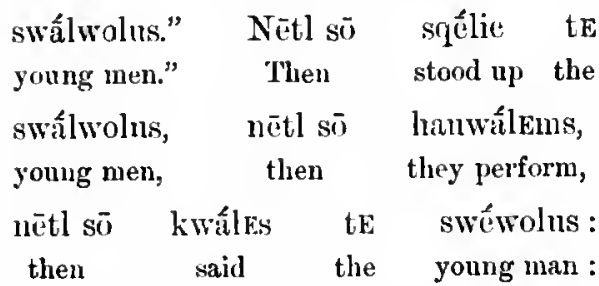

“Tō-yukwolsipátla!" nētl sō liwấles "Let the fire be made up!" then said te sElálōq: "yúlkwolsip!" nauns-te the old-people: "make up the coming-to fire !

QEtlqutlam kwà nütstem." nētl sō appear some wonder." Then umès. sqēlie nètl sō kwáles : he came he stood up then he said : "Namïtla kwénet kwa 'súma."

"Go get a kettle."

Nètl sō nam te swáwolus kwenetes Then went the young men took

tE 'súma, leêtl sō QRénQ̨es nētl sō the kettle, then they carry it then tlákuts stetî́s ute haiyuk, nētl sō they set it netr the fire, then nauns, nëtl sō kwaiyélic strtî́s he went, then he danced close atE 'suma. Tōo-luís-tsa kw's-kwaiyếlic, to the kettle. A while he danced, tsultsulấntsa kwaiyélic, nētl tsa sō from-enc-to-end he danced, and then

$\begin{array}{ccc}\text { Qōkáles,' } & \bar{e}-w \bar{a} & \text { nètl tsa sō } \\ \text { water appeared, } & \text { then he } & \text { continued }\end{array}$
kwaiyélic, nētl sō wéles te sấkwai, to dance, then appeared a sahnon,
eáqEs. èts kwa mẽ tõ hís, bed-his. When a little time had passed, ēmēk'ap te keq nistêne, assembled a multitude of people, ê-tlās-Es-wï kwśles te sīyálakwa : then spake the old-people:

"Tauhauwálematla swāwolus."

"Let us see you perform young men." ê-tlās-wā sqēlius te swáwolas, Then staod up the young-men, é-tlās-wa hauwälems, êt-tlās-wā kwEles

then they perform, then said tsä swéwolus : "Tō-yúktatla!" the young man: "Let the fire be made up!"

é-tlīs-wä kwéles te sìyálakwa:
then said the old-people:
"Yūktatla,
"Make up the fire, we are going to see some tEtEán!" é-tlās-wä mēs, sqêlius, wonder!" Then he came, he stood up, e-tlās-wä kwńles: "NEmâtla kwénit then he said: "Go bring kwa sçúma," é-tlas-wä nEm te a kettle," then went the swáwolus kwénites te sçuma, young men (and) took the kettle, é-tlas-wï QEếnQes, tlákates stetés then they earry it, they set it near tE haiyuk. é-tlais-wii nEms tố-tlī the fire. Then went be é-tlīs-wetl kwaiyêleHs nè te and then began to dance around the sçúma. Tōhís-tsa kw'skwaiyếleHs, kettle. Awhile he danced, tsultsulấntsa kwaiyélirrs, ề-tlīs-ks-wä from-end-to-end he danced, and then mès wìl te k’a. é-wiátl tsa came to appear the water. He often kwaiyćlius tō-tla. ē-tlās-Es-wii mēs danced that man. Then came wìl te sókwäi, ē-tlō kelắt a ppearing a salmon, yet again

' The phrase nētl só wíles to ka could lave been used liere, but this expression is morc idionatie. 
é-tlī kelắt wīl te sákai, nētl sō then again appears a salmon, then yesălis, nētl sō tcítem sEnếȳu there were two, then they swam about úta 'súma. Tō-hís kw's-quítes tsa in the kettle. Awhile they remain nètl sē sō sư.

then disappear, mẽ wīl tE-tlō sōk'wäi, ē-tlās-wä came appearing another salmon, then yisális te sók*waii kw's-Hêtems nē two the salmon that swam about in tE sçúma. Tōhís k'squtEstsa, the kettle. Awhile they remain ế-nē-tlō-nEm-īl sōq.

then all disappear.

\section{Cìyus utl Tsōqếlem.}

History of Tsōqúlem.

Tso Qá̊a ōqtcắnen stä kw's smīyus. tluktấmits, yémic QEáqa He had magic power he ran like a deer. He wastall, he moved lightly kw's émic, skwē kweusátlemet kw's íénic. Kākaít te smistếmuq, when he walked, can't hear him when walking. He killed the people,

tlấnk·utes. Tsa kanwétsen smant nētl lắlemps lälem utrl, yuq-spās. he robbed them. The Cowitchin mountain was his home the home of a one-time-bear.

KEq skwolás sEnēwa lẩlem ut’l spās, sEnêū tsa haíEtens. Tō sīy-âluq Lots of guns within house of bear, inside the ammunition. He was half-witted Qon slétlkutl, smútuksen, klōwêtsa, tlúkwelûs QunEm unítl kw's étsums, when a boy, running-cose, naked, heedless as to any clothing, aúa kw’s étltens, émic útsa sấluk muk•u skwáil, ts’tcimẩisen, withont any food, roaming in the woods every day, dribbling-at-mouth, tōtláwistem tsä kúlEmps, trtsálnūu. Qaíyākwetsten cánaqEs te slétleketl shifty his eyes, as-an-animal's. Qaíyākwetsten saw the boy nétsa skwâil, nētl-so túlmuqg wā-tsā kweles tsa wā-ếmēs sēsāt one day, then know-he what-kind-of-person will be when becomes grown-up swékka. "Oh! éi ṫsa kúluñs.” “NEñåna, Enấtea Enắ-tlā!” “Qona kwEn-siñ man. "Oh! good his eyes." "My-boy, come here!" "Now go and get (me) uks skwiláliñūq-Qêtlte." Kwániñıt. TE swếEka e eyū-amut. a blackberry-bush." He went for it. The $\operatorname{man}$ there was sitting. Qĩyanấlus teátcil te swéeka, ákwesten, sō kwÉnets. He was smiling (the boy) he came to the man, he gave it to him, then he took it.

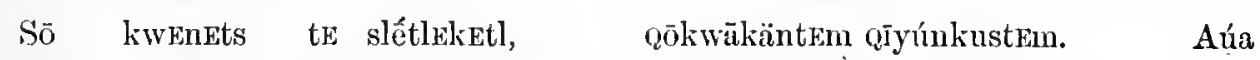
Then he seized the boy, threw him on his back and rubbed his face. Not kw's sqains tr slêtleketl, ūäinkumal, súqwon tsaāsus. "Kwămkwum ten he cried the boy, only grimerl, bleeding his face. "Strong your kúlem ōmē qútsa swékka." Nētl sō kwäts, ếi ckwálawons staluku. eyes become when a man." Then he went off, good bis heart in the woods. 
Qon ếnic-wutl-tsátlumbtes qēqun em. Nêtl-sō tluteánEm. Nētl-sō cấnuks While he was walking he heard a barking. Then he cautiously walks. Then he sees te swékka $\bar{e}$ tr stáles $\overline{\mathrm{e}}$ te ménes. Kwenátes te mistếmuq a man and the wife-his and the child-their. He was clutehing a human-being thaiyeqtes. Cáietkn te skásus. "Amếtla! umut-tla." Nētl-sō eating-him. Hairy the face-his. "Come here! and sit down (said he)!" Then ¿ēmuts te slēuk $\bar{c}$ ákwistem te slêtlekutl. KwEukts. "Tlaikq't'tla!" he clutched some flesh and gave it to the boy. He (the boy) took it. "Fat it!" Nètl-sō tlaiequis. "Ītc tse qéluq aíyū nè tsen sa. Amétla, tlâkuset." Then le ate it. "When you fight then there I will be. Come here, lie down." Nètl sō tlakuskits te slếtlekutl. "Aúa ếiyis tsen kúlem. Sétsen sa tEn Then lay down the boy. "Not good your eyes. Heal-I will your kúlkin. Kw's sō nētl swékia yumk usãm aúa eúkus tsen kúlem. Aúa cúkus eyes. Wheu that man rubbed your face not finish your eyes. Not right tskn kúlkm." Nêtl sō kiwḱnets tsa squtsalē. Nētl-sō mêakuts úte your eyes." Then took he a humming-bird. Then he pricked at-the cwúlnuts ten kúlEm. Sō soánulus. "Nēêtctcuqunat tE skwếyil? side-of the eyes. Then it bled. "Can you see the sky?

aúa-kwoz cānuq tsa kwấsen wutl-súq wom?" "Nē-teen wutl-cănuq tsa cannot you see the stars while-bleeding?" "I saw the

kwăsEn." "Ilúkwilûs wì suấtes kwuskwantcinEm, klau-stäääl." stars." "Careless if at-night you are running, just-as-in-daylight." Nètl sō sōtâk "us. Nêtl sō kwaiélic sō tcúEns: "ētsEn utl téna stấlEm Then he went home. Then he dances and sings: mestémuq yuqas kwenas utl téna stánelet qas $\bar{a} \bar{a} \bar{a} . "$ Nêtl sō nümps Then be goes to LEmáltca. Tlêtliắcin nonetsa slẩi nē utsa cätl wāwutletas Lemaltca. They were feasting (there) one woman there in the doorway keeping-away tE skwumkwumai. Kwwenátes $\mathrm{tE}$ skäluq. Sōqélem nūwêlem. Sōqélem the - logs She held a elam-digger. Süqélem sprang-inside. Sūqülem kwíluetes skyáisila nistémuq. Soqélkm tcấtlum. Tsä $\begin{array}{ccccccr}\text { shot } & \text { two } & \text { men. } & \text { Sóqếlem } & \text { jumped about. } & \text { That } \\ \text { slani } & \text { skélun } & \text { lite } & \text { ewímut. } & \text { Nëtl sō } & \text { tátsels } & \text { stetấs } \\ \text { woman } & \text { sprang } & \text { upon the } & \text { bed. } & \text { Then } & \text { came he } & \text { near. }\end{array}$ utrísa. Nètl ne sō kwenát qấtlet te skáluq. Netl sō Then she held him across the cliest with the root-digger. Then tans: "Amétla! étsen wnt] kwun-nuq, aúateūq skwElácus kwa she calls out: "Come here! I have gothim, don't you bring a unétūq, s'kūkwım'stcūq." Nêtl sō títsels sE tấles ē-yū-kwenüin utsa gun, axe you him." Then came her husband bringing. an 'skūkwum. Kiákwuts te sqafus, nētl sō mếuktâwit. Nētl sō axe. Hestruck him on the heal, then cut-off-the-hend. Then tsíthluns te sluk'wiits leès kw's tsítlums. junping about the healless-body long-time it was jumping. 
STORY OF 'Tsōqûlens.

About sixty years ago there lived at the foot of the nountain near Cowitchin Harbour a strange and fierce unan named Tsōqélenı. He was taller than the average man by nearly a foot, his face was long and thin and his tread was as soft and stealthy as that of the nountain-lion, and he conkl run like a deer. $\mathrm{He}$ became the terror of the district, waylaying and robbing anyone who crossed his path. His lome was a cave in the side of the momntain, in which he always kept a goodly supply of fire-arms and anmunition. From his boyhood he had been a strange being, passing most of his time roaming in the forest or mountains. His eyes were shifty and roving like those of a wild animal. A great Shaman once saw him at Saanich, and said to the people round about him: "That boy has got remarkable eyes." The boy stared at the man, and would have lun away but the Shaman caught him, and bade the people get him some trailing blackberry brambles. With these he rubbed the boy's face, saying as he did so, "I hope your eyes will now keep strong." The boy's face was severely lacerated with the thorns of the brambles, but lie did not ery, he simply grinned all the time, and when the Shaman let hin go with the command: "Run!" he ran off by hinself into the forest again.

T'sōquélem now wandering through the forest, hearl a noise before hin like the growling of a dog over a bone. He crept stealthily forward and presently perceived a hairy forest monster who, with his wife and children, were devouring in clog-like fashion the body of a youth they had seized.

The monster lyeld his victim on his knees, and with his long fierce claws tore off the flesh and passed it to his children. He accosted 'T'sōqélem, bidding him sit down. Tsōqélem sat down and the monster passed him some of the flesh. T'sōqélem ate like the rest. The monster then suid to Tsōqcelsu, "When you fight and when you kill people I shall be with you. Cone here to me and lie lown. There is something in your eye. That Shaman did a good thing who rubbed your face, but he only half did his work ; I will finish it." So saying he took the bill of a humming-bird and thrust it in the corner of the boy's eyes, telling him to look upwards till he conld see the stars. From time to time he questioned him, "Can you see the stars yet?" Tsōqélem answered "No" at first, but presently the star's became visible to him through the blood of his eyes, and he cried out: "Yes, I can see them now." "Very good," said the monster, desisting from his task; "from this time you will be able to see as well in the dark as in the light; lay and night will be all the same to jou." Tsūqélem now went back to his cave home and danced and sang his mystery song: " ètsen utl tEna stälem qas ! a ! a ! mustēmūq yuq qas kwenes. utl lumstalt qas ! a ! a!" which signified that he had been given human flesh to eat While he danced he flourished his gun and knife.

From this time onward Tsōqélem went about the country killing and robbing the people. After many years of this life he one day went to the Semaltca people on Kuper Island. It was about spring time, and the people were all assembled together feasting in one of their long-houses. A young woman sat in the doorway 
holding her digging stick in her hand with whiel to keep ont the dogs. All at once a gun went off and a man fell shot, and then another and Tsōqélem was amongst them brandishing his weapons and killing all within his reaeh. Everybody made for the door except the young woman who held the digging stick. She sprang upon the bel platform, and as T'sōgélem passed with his baek towards her she was suddenly inspired with the thought that she could hold him down with her stick. Seizing her digging stiek at both ends, she quiekly passed it over his head and held it tightly across his breast and pulled him backwards, shouting as she did for her husband to eome and kill him while she thus held him. Tsōqélem struggled laard to break away from her and sought to stab her with his knife, but she held him fast and shouted the more. Her cries brought an old crone to the door, who called out, "Has he got you down?" "No," she replied; "I have got him down. Tell my husband to come quickly and bring the other men with him." The husband presently eame, lushing up, followed by the other men. As they entered the house, the woman said, "Don't use your guns, attack him with your axes." This they did, soon disabling him; they then cut off his head and his body rolled and jumped about for a long time. When they cut him open they found that his heart and entrails were very small-much smaller than those of any ordinary man. Thus was Tsōqélem slain by the wit and pluek of a woman.

\section{Kanitsen Account of a Great Flgit between the Salish Tribes and their Heredtaky Enemies the Kwakiutls.}

Once the Kauitsen were at war with the tribes on the Ameriean side of the Straits. While they were absent from their villages some of the Kwakiutl bands swooped down upon their settlements, burnt their houses and carried off the women and children into slavery. When the Kauitsen warriors eame back they found their homes destroyed and their families earried off into slavery. Nothing was left to them but the smoking remnants of their dwellings. Not even a dog remained. They set their canoes to dry and then gathered for consultation. While the meeting was going on a youth from the Snanaimō tribe eame running up with information respecting the marauding tribes. This youth had seen their camp fires. Said he, "I saw five hundred and cighty cooking fires on the beach at Nanaimo, and I think they will stay there for a little while. If you hurry after then you can lay in ambush for them at the mouth of the harbour." The Kauitsen immediately sent out seouts to search all the bays between the Kauitsen Harbour and that of the Snanaimon; they also sent off messengers to the other friendly Salish tribes witl urgent requests to join them in their attack on the Kwakíutl. A ready response was made, and before the dawn of the next day the war canoes, each with its eomplement of thirty-five warriors, of all the Salish settlements on the Gulf and lslands rende\%voused at Kanitsen Harbour. The sconts had returned in the ineantime with the news that the Kwakiutl were eamped at Maple Bay with their eanoes all hidden in the woods. When all the war canoes lad arrived they set 
out for Maple Bay, forming their company into two divisions, one of which was stationed on the right and the other on the left of the entrance to the bay. It was agreed among them that three eanoes of KanitsEn warriors disguised as women should row into the harbour and entice the Kwakintl to eome after them. A system of signals was also agreed upon. The sounds were to be those of the owl, the wolf, and the dog. The cry of the owl was to be given by the Kauitsen as soon as they saw they were pereeived by the Kwakiutl, the sound of the wolf when the Kwakintl swallowed the bait and began to pursue them, and the sound of the dog would be given by those in ambush outside of the harbour to signify that they were ready to dash in and surround the enemy. When all was ready the Kauitsen canoes with the men wearing big hats, such as the women eommonly wore, to make them appear like women, entered the bay. Before they are half-way in they are diseovered by the Kwakiutl, who launch their eanoes and set off in pursuit. They give the signal and turn about and paddle back, followed eagerly and carelessly by the Kwakiutl who fail to observe the canoes of the Salish stealing in on either side of the bay. Presently when the Salish have got into the bay and surrounded them, they give their warwhoop and the Kwakintl perceive that they have fallen into an ambush. The Kauitsen now elose in upon the Kwakintl, and a fieree battle begins whieh, the Kauitsen say, continued without intermission for four days and nights, and the waters of the bay beeame red with the blood of the slain. In the end fifteen eanoes of the Kwakintl broke through the eordon of the Salish and made for the open sea. Of these one was swamped off the point, three ran on a subunerged reef and were wreeked and the rest were overtaken at Nanoose and their erews all

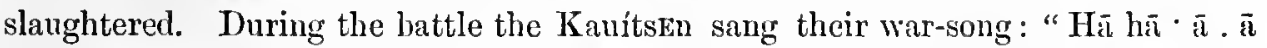

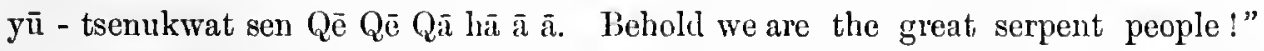

When the Salish had vanquished their foes, they determined to retaliate and to earry the war in to the territories of the Kwakintl and their allies. Accordingly they made for the settlements of the Sintlótlq (now Comox) whose fighting unen had been among the Kwakintl. The Sittlotlq, though properly Salish, were always regarded by the Kauitsen as Kwakîutl because of their allianee and sympathy with this stock. When the Sätlotlq women saw the canoes coming into the harbour they thought it was their own lusbands and friends returning laden with the spoils of their foray, and ascended the roofs of their dwellings to dance and sing the song of weleome. Presently, when the eanoes were at the landing they perceived their nistake and would have run away and hidden; but the many Silish slaves whieh they held, perceiving their countrymen in the eanoes and surmising the object of their visit, seized upon both women and ehildren and held them prisoners. The Kauitsens now came forward and bound all the Sátlottiq. After setting fire to the village, they took them away with them as slaves. From thence they went on to Cape Mudge, the home of the dreaded and warlike Xukwitltaq, the southernmost of the Kwakiutl proper, and did the same thing there. They then proceeded to Alert Bay to the ehief settlement of the Kwakiutl, and this they served in the same way, pressing all the women and ehildren into slavery. Thus the Salish tribes 
punished the Kwakiutl and their allies and so broke their power that from that time onward till the comntry passed into the hands of the whites they were free from the attacks of the Kwakiutl and conld live in peace and security.

There is no doubt, I think, about the truth of the main features of this contest, but whether the Salish were as victorious as the Kanitsen relates may possibly be open to doubt.

\section{Clairvoyant Power in Women.}

The Indians everywhere believed in clairvoyant powers, and relate many instances of the exercise of such. The following is an example given me by Thomas James.

A hunter once lost his hunting knife. . He did not discover his loss till he had brought home his game and shared it with his neighbours. The loss of his knife made him sad, and the people ask him why he is so sad after lis snccessful lumnt. He tells them he has lost his lunting knife, and one of them replies, "I know a wise old woman who will help you find your knife." The hunter was pleased to hear this, and said, "I will give her five blankets if she does." The old woman is sent for and told what has oceurred, and begged to use her powers in the recovery of the lost knife. She replied, "I certainly used to have the power to see lost things, but I have not exercised it of late. I don't know if I can do it now, but I will try."

She thereupon sat down, closed her eyes, and began swaying her body. Presently she passed into a trance-like state, and when she recovered she was able to describe to the hunter where he had been, and just where he had dropped his knife. The hunter returned to the forest, retraced his steps to the spot indicated by the old woman, and there found his knife lying where she had seen it. 
<smiles>C1CCCC1</smiles> 
2.

REPORT ON THE ETHNOLOGY OF THE Sİ́CIATL OF BRITISH COLUMBIA, A COAST DIVISION OF THE SALISH STOCK.

By Charles Hill Tout, Local Correspondent of the Anthropological Institute. 
<smiles>C1=CC=C1</smiles> 
2.

REPORT ON THE ETHNOLOGY OF THE SİCIATL OF BRITISH COLUMBIA, A COAST DIVISION OF THE SALISH STOCK.

By Charles Hill Tout, Local Correspondent of the Anthropological Institute. 


\section{REPORT ON THE ETHNOLOGY OF THE SÍCIATL OF BRITISH COLUMBIA, A COAST DIVISION OF THE SALISH STOCK.}

By Charles Hill Tout, Local Correspondent of the Anthropological Institute.

\section{[With Plate J.]}

THE following notes are a summary of my studies among the Síeiatl. I have been enabled to eonplete them earlier, and in a more exhaustive manner than I could otherwise have done, by a timely grant of $\mathfrak{f} 40$ from the Royal Society. By means of this help I was able to spend the greater portion of a month among them in the summer of 1902, visiting their different settlements and gathering all information now available from the most reliable and anthentie sources. With the exception perhaps of a few folk-tales, I believe these notes reeord all that may now be gathered of the past coneerning this tribe.

Of all the native races of this provinee, they are probably the most modified by white influences. They are now, outwardly at least, a eivilized people, and their lives and condition compare favourably with those of the better class of peasants of Western Europe. Their permanent tribal home, or lreadquarters, eontains about a hundred well-built eottages, many of them two-storied, and some of them having as many as six rooms. Each house has its own garden-plot attached to it, in which are grown European fruits and vegetables. In the centre of the village, and dominating the whole, stands an imposing church, which eost the tribe nearly $\$ 8,000$ a few years ago. Near by, they have also a commodious and well-built meeting-room, or publie hall, eapable of holding 500 persons or more, and a handsome pavilion or band-stand fronts the bay. They possess also a convenient and effective waterworks system of their own. The water has been brought in iron pipes from a mountain stream some three miles off, and every street las its hydrants at intervals of 40 or 50 yards. From these, the water is easily earried into the houses in pails.

As a body, the Síciatl are, without doubt, the most industrious and prosperous of all the native peoples of this province. The men engage either in fishing or lumbering the whole year round. Some of them are also expert hunters, and during the season ship a great number of deer to the Vaneouver market, their territory abounding in game of that kind.

Respecting their improved condition, their tribal and individual prosperity, highly moral eharneter, and orderly conduct, it is only right to say that they owe it mainly, if not entirely, to the Fathers of the Oblate Mission, and particularly to the late Bishop Iurien, who more than forty years agro went first anong them and 
won them to the Roman Catholic faith. And most devout and reverent converts have they become, cheerfully and generously sustaining the Mission in their midst, and supplying all the wants of the Mission Fathers when amongst them.

\section{Ethnography and Sociology.}

The tribe, as at present constitnted, numbers some three hundred and twentyfive souls, between sixty and seventy of whom are adult males. It is a very difficult matter to get the exact number of any Indian settlement. Census-taking is something entirely foreign to the native mind, and no inhabitant of a native village, even when it contains less than a score of souls, can tell one offhand the number of adult males living in it. Wheu questioned upon the point, they have to count them off by name upon their fingers, and are then as likely to overlook some as to give an accurate total.

The Síciatl are obviously a mixed people. The facial types among them would make this quite clear, even if we had no evidence of the fact in their traditions and genealogies. At the time when the late Bishop Durieu first came among them in the early sixties of the last century, they were divided into four septs or sub-tribes, each having its own settlement and fishing and hunting grounds. These wcre in the neighbourhood of Sechelt peninsula, the neck of which commences about twenty or thirty miles above the entrance to Howe Sound, the waters of the neighbouring Skqónic. The present Mission, or headquarters of the united tribe, situated on Trail Bay on the onter side of the neck of the peninsula, is of modern origin, lating only from Bishop Durieu's time. Prior to that, though a most desirable and sheltered spot, fear of the blood-thirsty, marauding YúkEltais (a Kwakiutl subdivision) prevented them from making a permanent settlement here. Known to them by the name of TcatElëtc (= "outside water") it formed a temporary halting place and general rendezvous for the tribe. Here the different septs sometimes met for a common hunt. The neck at this point formed also a portage to the divisions living on the inner waters, and made a sholt cut for them to the Gulf, being only eleven hundred yards wide at this point.

The following are the names and settlements of the old divisions of the tribe :-

QúNĒTCIN, at the head of Queen's Reach.

Tsóxu, at Deserted Bay, the junction of Qucen's Reach and Princess Royal Reach.

TŪWÁNEKQ, at head of Narrow's Arm.

SQAIAQŌs with many settlements, but no fixed abode.

Of the above four subdivisions, the two former are said to be of extraneons origin, being founded by men of Kwakiutl lineage. The two latter represent the true Síciatl. Fegarding these septs separately, the Tsónai now number abont forty souls. I gathered from the chief and his brother all that is now known of their ancestry and past. They have a genealogical table, extending back to the sixth generation, that is, to their TópIYuk. The genealogical lists of all the Síciatl 
divisions stop at this point. They have no memories or traditions of anything beyond. The Tópryuk is always with them the "first-man."

The following is the genealogical table of the Tsónai ehiefs :-

Qōlálin I.

Qōlấlin II. eldest son of Qōlálin I.

Teauk:st I. eldest son of Qōlálin II.

Unakwáteī, husband of Tselápolt, eldest danghter of Teauksst I. 1

Tcáuk'st II. eldest son of Unakwátei. Otlkēn, secoud son of Unakiwátei and present chief of the Tsónai.

It would appear from the family traditions that Qōlálin I. was not originally a ehief of the Tsónai. It is related that he aequired the ehieftainey by execlling all others in "potlateling"; and he is said to come from Fort Rupert." His name bears witness to his greatness in this line, the term being derived from the root Q Qōtsōt, " to hold in a bundle," or "press down," i.e., all other competitors. He was a man of great wealth. He possessed a kind of Fortunatus' purse in the form of a têtêléte= "increasing." This was described to me as a kind of baby that he found in the forest one day and took home and placed in a box, which immeriately became filled with potlateh treasures of all kinds. Hence his alility to excel in potlatehes, and henee his name. He possessed also a large house ealled Kwōsen-aut $=$ "star house," so named becanse the roof was - construeted in such a manner that the stars eould be seen through numerous small holes in it. No rain ever came in through these star-holes. Adoming the structure were inany squtk, , that is, carvings and paintings of animals. I was assured that these squtk, were in no way totemistic in eharacter, nothing eorresponding to the totem erests or symbols of the northern tribes being known among the old Síciatl acording to all my informants. They were simply symbolieal of the social status of the owner. The figures were such as in the natire mind typified greatness, loftiness, strength, power, wisdom, and so on ; such as the eagle, the raven, the bear, the whale, and the beaver; and their number and variety on a man's house or belongings marked the measure of his ability to excel in potlatching. Only men of acknowledged position in the tribe ever ventured to lecorate their houses with sueh earvings or paintings. The ridicule of their fellows effectually prevented any man from undeservedly aequiring these distinctions.

When Qinlílin was advaneed in years, he became desirons of securing his eldest son's succession to the ehieftaincy; and to ensure this he gave a great feast, pnhlicly resigned the chieftainey, and nominated his solı as elief in his stead, giving him at the same time his name and all his wealth. As no one could now 
dispute his claims to the office, Qōlálin II. was acknowledged chief of the tribe. He took to himself nine wives, by whom he had ëpedálĩ túīkwels, "ten offspring." When he became aged, he followed his father's example, gave a great feast, and distributed many presents. At the close of the feast, he led forward his sons and daughters, and declared his eldest son chief in his stead. His name was Tcauk'st which signifies of clean or lonourable descent; implying by this that his parentage was above reproach, that he had no slave blood, or dog-blood, or other' animal blood in his veins. He was regarded by all as "planted " firmly or deeply in the headship of the tribe.

Tcaukst had one wife only, by whom he had sēlatsáli túîkwels, two sons and three daughters. His sons both dying, when he reached a ripe old age, he gave a great feast and named his eldest daughter Tselápolt as his successor and chieftainess of the tribe. Later she married Unakwattci, and he, taking his wife's rank and privileges, became a chief. By the help of his father-in-law, he gave many potlatches, and was acknowledged as supreme chief. It was during the chieftaincy of Unakwatei that Bishop Durien came first among the Síciatl. He was welcomed by this chief, and in return, it is reported, the bishop gave Unakwâtcĩ a bell, and made hin and his successors hereditary chiefs of the Church which he established in their midst.

Unakwâtcì had seven children, two boys and five girls. When he was advanced in years, the bishop made him "sit down," and named his son Tcáuk-st as chief in his stead. But Teáuk'st's mind becoming unbalanced later, he was set aside, and Unakwattcī was reinstated in the office, which he held to the time of his death. As his successor, the bishop appointed his second son ottlkēn, the present occupant of the office.

I have thought it worth while to give the family history of the Tsonai chiefs as they gave it to me, because of the sidelight it throws upon important practices and customs.

In addition to the above genealogical table of the Tsônai chiefs, I obtained the pedigrees of the chiefs of the Sqaíaqos and TñwánokQ. It is worthy of remark as showing how deeply their modern environment has modified their lines, that only one person, an aged woman, knew or remembered the genealogical tables of the chieftains of these septs. Concerning the family history of the chiefs of the Qnnétcin division, I could obtain no account whatever, no one apparently possessing any knowledge thereof.

The following is the genealogical table and history of the Sqaíaqōs.

According to the belief of the natives, the founder of the Sqaíagōs was te spílamñtl, " « heaven-born man" named S'ónketl. He had a brother named Sukâll, who became a secondary chief, and a wife named Yálqōmolt. He is said to have first appeared at a place called Smet, which is at the head of Hotham Sound. This meagre account is all that can now be gathered concerning the past of this subdivision of the Síciatl. The pedigrees of S'óntetl and his brother Sukál as given to me are as follows:- 


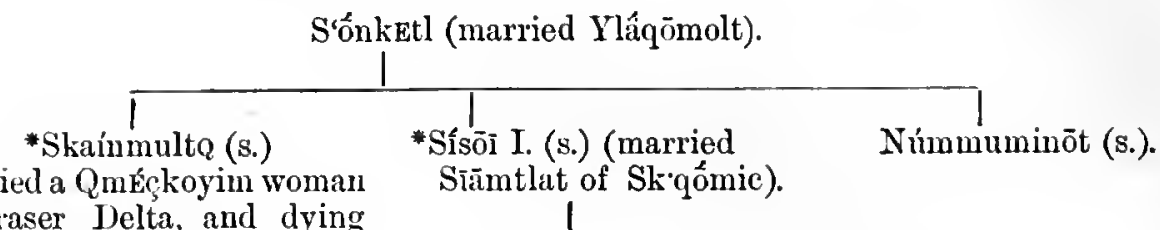
(married a Qméçoyim womaı of Fraser Delta, and dying without issue was succeeded by his brother Sísūi).

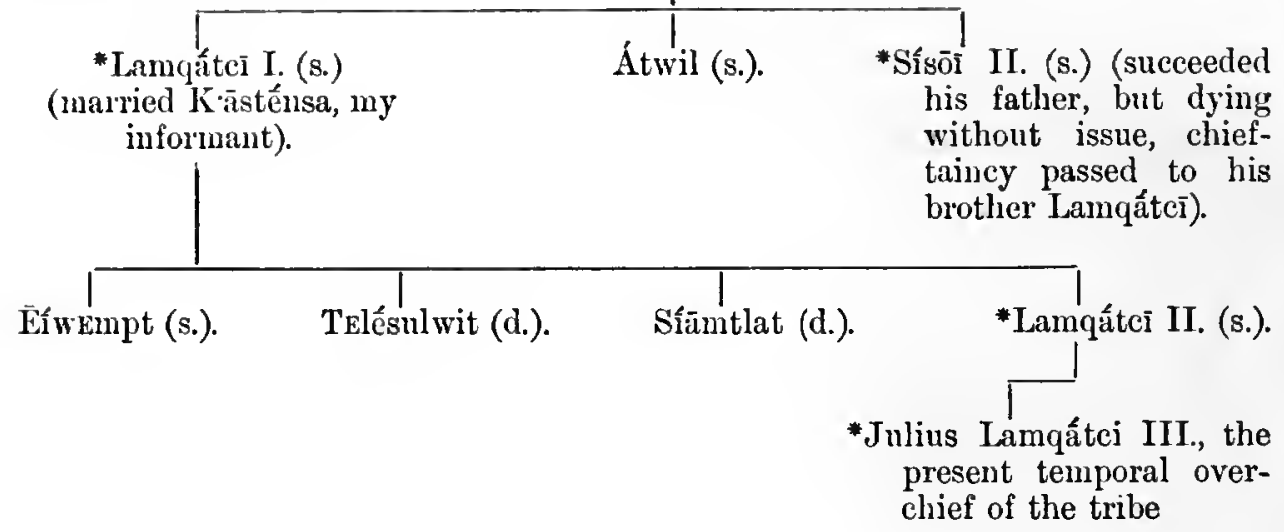

The following is the pedigree of Sukál:-

*Sukál = "lofty post"

(married NuknēkwElwit of Slaiamon tribe), issue three sons.

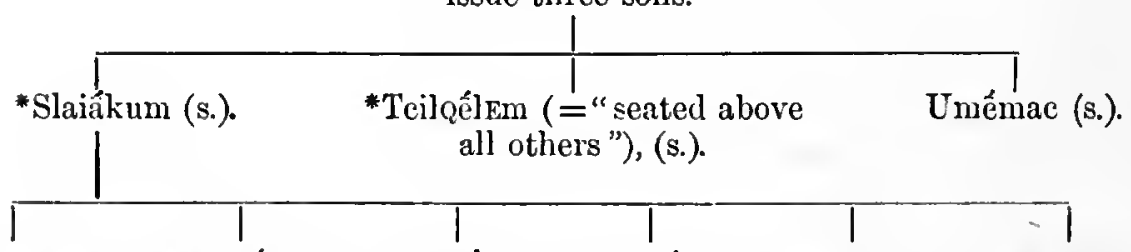

Yeqaieça (d.). *Manáçía (s.). Q̄eoóia (s.). Sukál(s.). Sáctlem (s.). K’átakis (d.). All these offspring of Slaiákum dying without issue, the chieftaincy passed to Tcilqélem, his brother.

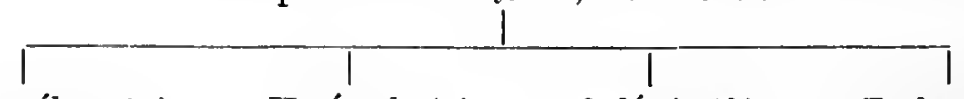

* Sukwélten (s.). Hasámels (s.). Qeléwit (d.). Tsultsulmat (d.).

*Thúkten (s.) (died with- Haik, (d.). Petémmlto (d.). *Hétealt (s.). ont issue and was sne(Baptismal name ceeded by his brother Jack Isidore, the Hếtcalt). present representative).

N.I.-The names marked with an asterisk were ruling chiefs, (s.) and (d.) stand for "son" and " daughter." 
Tūwấneke Sept.

The founder of the Tūwáneke division was also te spélemūtl. His name was Tlentckénem. His successors were Tlentckénen II., III., IV., V. and VI., who is now a small boy.

We learn from these Family Tables that the chieftaincy was practically hereditary, althongh theoretically within the grasp of any member of the tribe who could outdo the ruling chief in potlatching or feast-giving; and it is not withont interest to observe that the same anxiety and ambition to found and perpetuate a family, displayed in modern society, are equally factors in the life of savage races.

Socially, the Síciatl people were divided into three castes or classes, as in the other Salish tribes examined, viz., chiefs, nolsles, and base folk. We have seen how the first are constituted; the second were composed of the heads of families of standing, and, generally, of the wealthy. The last were made up of the thriftless, the indolent, and the slaves of the tribe. I made special and repeated inquiries with regard to secret societies and brotherhoods, and induced my informants and helpers to question in my prescnce the old men and women on these points; but all were unanimons in declaring that nothing resembling the modern secret societies of the Kwakintl, of which they have some knowledge, had any place among the old-time Síciatl. The nearest approach to anything of the kind was the initiation of the pupils, or disciples of the Siyaikwetl (medicine-man) or the Siwsin (seer), who were accustomed to attach a few followers to themselves after the manner of apprentices. My own conclusions respecting the social life of the old Síciatl, formed after careful study and inquiry, are that it was of a very simple nature, and similar to that of the interior Salish tribes. The war-like division of the Kwakiutl stock which ruled the waters of the Strait, and kept the Síciatl isolated from other influcnces, effectnally hindered the acquisition of forcign ideas or conceptions from those quarters; and the large influx of Lillooet blood in the present Síciatl suggests close relations with that tribe, if not original descent from it. Of the two dozen photographs which I obtained among the Síciatl, a preponderating number are those of individuals with Lillooet blood in them. Another thing which points to relationship, or at any rate close contact, with the interior Salish, is the fact that they formerly practised that pecnliar custom of secluding certain of their children; a custom which my collection of Thompson folklore shows to have been at one time prevalent among the N'tlakípamus, the neighbours of the Lillooet tribes. A propos of this practice, I learned from Charlie Roberts that the object of this seclusion was, in the case of male children, to make great hunters of them; great, that is, in the sense of securing by some occult means large quantities of game. They are said to have been quite white in appearance, much lighter than the average settler, from their long seclusion. They were shut up in box-like receptacles, and never allowed out of them, or the house, save at jight, when they could not be seen. Another peculiarity was that their hair must never be cut. These individuals aronsed much curiosity in the other members of the tribe, and all kinds of schemes were resorted to in order to 
get a sight of them. In the case of youths, when it beeame known that one was about to set ont on a hunting expedition, the young women would do their best to get a glimpse of him, and if possible, would waylay him, and induce him to break his celibacy in the hope of securing lim for a husband. For, if a young man lay with a maid, she became ipso facto his wife. On leaving the house, they were always covered up with blankets, and were conducted by some near relative into the forest, until beyond the gaze of the curious and prying. They were supposed to possess supernatural powers of some sort. It is recorded of one that he went out fishing with his brother, and while they were engaged in their work, a young female seal popped up its head at a little distance from the canoe. When the youth saw it he cried out: "Oh what a nice young woman; how I should like her for a wife." The seal dived down, and his brother warned him to beware of uttering such wishes when so near a seal colony. But the youth took no notice of the advice, and made the remark again when the seal came up a seeond time near the canoe. Again it dived, but presently came up close to the canoe and assuming the form of a maiden, invited him to descend with her to the seal village below. He readily accepted the invitation, and dived down with her. After a little while he returned to the surface and bade his brother go home without him, saying that he intended to stay with the seal people. His brother urged him to change his mind, and accompany lim, but was in the end obliged to return home without him; and his people never saw hin again.

\section{Shamanism.}

The Shamans, among the old-time Síciatl, were of three classes: the Siyalkw'tl or doctor, the Siwwin or seer, and the Seúwa or witch. The last-named were generally women, the other two invariably men. Their practices did not differ in any essential point from those of their class among the other Salish tribes treated of heretofore. The Siyaikw'tl corresponded to the SQunatm of the Halkōmélem, the Siwín to the Olia, and, like him, possessed clairvoyant powers, and could discover lost persons or things. One hears many stories of the supernormal powers of these Sĩwin, and they undoubtedly possessed the faculty of perceiving distant and hidden objects in some degree. Not every one who desired conld become a Siwín. Only those whose psychical make-up fitted them for the office ever became Sĩwín.

\section{Suliaism.}

I inquired very particularly among the Síciatl concerning Sulia. In this tribe, as in the Sk-qónic, suliaism seems to have playerl a less prominent part than in the up-river and intcrior tribes. Not every one, it would appear, among these two tribes acquired sulia (called by them súly $\bar{u}$ ) or supernatural helpers. Those who possessed them werc, according to all my informants, mostly shanans, or distinguished hunters, or fishers, or warriors, or runners, or those generally who exceeded in any particular ching; the attendant bodily exercises and the protracted fasts incidental to the aequisition of sulia apparently not being to the 
liking of the ordinary individual. But as it was of the very essence of the sulia that its acquisition by the seeker should be kept secret from lis fellows, at any rate among the Sk*qómic and Síciatl, it is not improbable that this fact, and the long time that has elapsed since these tribes gave up their pagan habits and beliefs, hide from ns the true extent to which suliaism permeated the lives of the old-time Sk'qómic and Síciatl. Regarding the practice, however, merely from the point of view of my informants, we may yet perceive the significance which suliaism had in the mind of the natives, and the potent influence it exercised upon their lives. The importance of the psychical factor of this cult in the development of these races can hardly be over-estimated.

Among the Síciatl there seems never to have been any painted or sculptured representations of the sulia on the houses or other belongings of the individual. Such sculptures and paintings as were displayed being, as I have already stated, honorific, and not totemistic in character. The import of this calls for consideration, for we have in these figures apparently another source or origin of personal and family crests. The son inheriting his father's house and rank, inherited with these all his carvings and paintings; and it becomes important in our studies of the social customs of the tribes of this region, and particularly of their crests and emblems, to determine which are honorific, which totemistic, and which merely commemorative in character; also to what extent the first were formerly employed, and what part they have played in the giving of animal names to individuals, families, and clans. For it seems impossible to doubt that figures of animals were used by other of the north-west tribes to symbolise the social status of their notabilities. Indeed, Father Morice has shown that the Déné tribes of the interior employed a like symbolism for that purpose, ${ }^{1}$ and signs of it are not wanting in the heraldic columns of the northern coast Indians. It is quite likely that we have sometimes confused the honorific symbols with those of totemic import. Certainly, students of these races have customarily regarded house sculptures and paintings as being totemistic in character and significance; and while this view may be right in some cases, or even in the main, it is clear from my present studies of the Síciatl and Sk qómic, that it cannot be in all. It will be important then, in future researches, to distinguish clearly between the different classes of symbolism employed by our Indians.

Another point of some importance has been raised by my studies of the Siciatl. According to them, the acquisition of such a magic treasure or supernatural helper as the Têtēete of the ancestor of the Tsónai chiefs, did not result in the founding of a new crest or totem as was invariably the case among their northern neighbours. No carvings, paintings, or other marks were employed to symbolise such objects or possessions, or to commemorate their acquisition. While this is possibly true, and is certainly in keeping with what we have learned of the Salish of the interior, too much stress

" "Notes on the Western Dénés," by the Rev. A. G. Morice, O.M.G. Trans. Can. Institute No. 7, vol iv, part i, March, 1894. 
should not be laid upon the statement. It is open to question whether the present Síciatl are at all times trustworthy informants upon the practices and beliefs of their pagan ancestors, two generations separating them from the primitive order of things.

That the forest, the air, and the sca were full of mysteries to them is clear from their folk-tales; and their anthropomorphic conceptions of the animal and vegetable worlds coloured all their lives and thoughts, as among their neighbours. Even to-day, among the most advanced and intelligent of them, there is still a strong belief in the human or man-like side of animals, plants, and other objects and forces.

This universal concept of primitive man seems to be one of the most persistent of his early beliefs.

There is also one other point to which I would like to draw attention. The Tsōnai sept claim, as I have before stated, a Kwakiutl origin. If this be true, and I know no reason why we should doubt it, the entire absence among the Síciatl of all those peculiar observances and customs, so characteristic of the Kwakiutl when they first came under our observation, would seem to indicate one of two things: either that the Síciatl mind was uncongenial to Kwakiutl institutions, which is very unlikely, judging by their adoption more or less fully by other Salish tribes; or, which is more probable, that the present social organisation of the Kwakiutl, with its strange societies, clan divisions, and elaborate winter ceremonials, is of modern origin. This is the view which Dr. Boas' studies of this people led him to adopt, and the absence of anything resembling these practices among the Síciatl, who claim relationship through one of their divisions with the Kwakiutl, certainly brings additional and independent support to that view.

\section{Dress.}

In dress the Síciatl did not differ materially from the other Salish tribes already described. Dressed skins, blankets, woven from the hair of the mountain goat and from a species of long-haired dog bred for the purpose, and capes and skirts from the inner bark of the cedar (Thuya gigantea) formed the ordinary covering of the people. In mentioning the celar as a source of clothing, it will not be out of place if I call attention liere to the unique value of this tree to the old-time native, and the many uses to which he put it, and for which it was so eminently adaptable. It was to him much what the cocoanut-palm was to the South Sea Islander. From its onter bark he constructed ropes and lines, coverings for his dwelling, his slow matches, or "travelling fire," and many other things. From its inner bark lis wife wove garments for herself and children, made their beds and pillows, padded her children's cradles, and fashioned the compressing bands and pads for deforming their heads, and also the insignia of their secret societies, their headdresses and other ceremonial decorations, besides applying it in a multitude of other ways. From its wood he built the family and communal dwellings, made such furniture as he used-tubs, pots, kettles, 
bowls, dishes, and platters, fashioned his graceful and buoyant fishing and war canoes, his coffin, his treasure chests, his ceremonial rnasks, his heraldic emblems, his commemorative columns, his totem poles, and a host of other objects. From its branches be made his most enduring withes and ties, and from its split roots his wife constructed the beautiful basketry of this region. There was practically no part of this remarkable tree which he did not apply to some useful purpose or other. He even resorted to it for food in times of scarcity and famine: his wives and daughters robbing the squirrels and chipmunks of their stores of its cones for the nutriment they contained. One can hardly imagine what the condition of the natives of this region would have been without this tree, no other of the country lending itself to such a variety of useful purposes. That it has had a profound influence upon their condition, and has helped to shape the lines of their culture, there can be no doubt.

\section{Dwellings.}

The dwellings of the old-time Siciatl were of the communal kind. They appear, however, not to have been so long generally as annong some of the coast Salish; the nature of the ground at these villages not being so convenient for this purpose. In height they ranged from twenty-five feet to forty or even fifty feet, according to Charlie Roberts, but I think these latter heights doubtful. Usually each house was occupied only by persons connected by family ties. Families with numerous ramifications wonld always possess a building of their own, but sometimes two or more small familics would share the same building between them. Isolated individuals, or those having few connections, would find accommodation in some family, whose dwelling was larger than their needs required.

The internal structure and arrangement differed somewhat from that of the other tribes. For example, at the building of the house a permanent platform abont two feet high and five or six feet broad was erected all round the interior walls. This served as seats or lomnges for the occupants during the day, and during the night as beds. Some ten or twelve feet above this platform small isolated cubicles or sleeping rooms were constructed. These were for pubescent boys and girls, who were confined separately in them for the space of ten days upon their reaching puberty.

Each family partitioned off its allotment from the rest by means of langing mats. There were no hanging shelves for storing food, as in the Sk-qómic and Halkōmélem houses, for the reason that their supplies were kept elsewhere.

\section{Food.}

The staple food of the Síciatl consisted of about equal proportions of venison and fish, supplemented by varions roots and berries. Their territory abounded in game, and their waters teemed with fish. As I have said, they did not store their winter supplies in their dwellings, but "cached" them in the woods. Only a few days' supply was ever carried home. This peculiar custom was due to 
the marauding proclivities of the neighbouring Yúkeltās, who made periodical forays upon their settlement and earried off all they could lay hands upon. It was nnsafe, therefore, to keep a large store of food by them.

In the matter of preserving the berries of their distriet for winter nse, they had, and still practise, a most ingenious method of treating them. On one of my visits among them $I$ was present when some of the women were making their winter "jam" from the salal berry, and I was thus able to observe the whole process. The fruit is first boiled for an hour or so, after which it is poured into a bowl and earefully mashed into a uniform jelly with a wooden pestle. A layer of large leaves is now spread over a kind of tray, made of narrow strips of wood fastened together by cross pieces. Upon the leaves is spread out a thin continuous layer of the jelly. The tray is then placed in the sun to dry, and when the upper side of the jelly has hardened into a eake, the whole is turned over on to another tray, and the other side of the layer is also left to dry out. When both sides are properly dried, the jam has the appearance of a piece of coarse felt, and ean be rolled up like a mat and stored away for use. Now-a-days they use sugar in the boiling; formerly, of course, they had to dispense with this. When they wish to make use of this preserved fruit, they break off a piece, steep it in water for awhile and then reboil it, just as we do the evaporated fruits of commerce. Cured and preserved in this way, they say fruit will keep in good condition from season to season, or even longer, if kept dry and free from mildew.

\section{Household Utensils.}

The Sifiatl made nse of utensils similar to those employed by their eongeners. Some of the women were very skilful in making the cedar-root basketry of this region. Even now, they make large numbers of them for sale to tourists, reeeiving from five to fifteen dollars a basket, according to size and quality. They had received an order just before my last visit to them, and many of the women and girls were busy in earrying it out. They employ only the small trailing roats of the bigger eedar for this kind of basketry. I was fortunate enough to be able to observe elosely the whole process from beginning to end, and, indeed, I may say that I received instruction enough to be able, in a elumsy way, to put a basket together myself. The actnal process of making is sinpler than the appearance of the finished produet would lead one to suppose. The most difficult and tedious part of the work is the preparation of the material. This, as I have said, is the root, or rather rootlets, of the cedar. These are dug up by the women with their skivlq, or root-diggers, and brought home in bundles. The longer the roots the better, but the thickness of them shonld not exceed a thumb's width. The roots are first peelecl or seraped, and, if not wanted at onee, are placed in a stream or buried in wet ground to keep them moist and pliable. If required at onee, they are halved and quartered longitudinally. This is done by means of a knife, and the hands and teeth, the latter playing a prominent part in the operation. The quarters are then split in the same manner into thin strands or splints of uniform 
thickness. Those that are not of uniform thickness are pared down to the required condition with a knife; but if too irregular for this purpose, they are set aside with the short lengths and broken pieces, to be used in the constrnction of the cores or coils of the basket. The strands are next tied separately iuto loose knots, just as one ties a bootlace or a piece of string, and thrown into a pail or pan of water ready for use. When a sufficient quantity of strands has been prepared, the woman sets about making her basket. She begins by putting together a core of the required length of the basket. This is made up of pieces of the cedar rootlets rejected in the process of making the strands, and varies from a quarter to half an inch in thickness. Round this core she next winds in close contact one of the strands, beginning at one end and finishing at the other. To both sides of this slee then stitches, by over-casting other cores, until the bottom is of the desired dimensions. Upon this groundwork the sides are built up, coil by coil, in the same way. The stitching is done by means of an awl, now usually of steel, but formerly of pointed bone. Each stitch of the lower coil is pierced in turn, the strand carried over the new coil, which is built up as the work proceeds, passed back through the hole and pulled tight. This is repeated all round the basket, until the coil is complete. The coils are thus built up separately, one upon another, and when the desired lieight has been reached, finished off with a crown of doubled or trebled coils. The basket is made sometimes with a close-fitting lid or cover and sometimes without, according to the pattern or the use to which it is intended to be put. Usually these baskets are more or less ornamented with variously tinted grasses and barks. The bark most commonly employed for this purpose is that of the wild cherry and of the birch. Fither strips of this, or the straws, or both combined, are hooked in on the outer surface of the basket during the process of making in the following manner :-One end is inserted under a stitch at some particular spot, and thus firmly secured. The strip of straw is then drawn over the face of the next stitch, and carried a little beyond it, then doubled back, and the doubled end fastened under the succeeding stitcl, and the process is continued in the same manner as far as the design requires it. Sometimes this ornamentation is exceedingly tasteful, and the colours soft and harmonious. In some instances, the strips of bark are entirely dispensed with, and only a glossy yellow straw is employed. In such cases the whole outer surface of the basket is usually thus covered, giving to it a shining silvery appearance, and hiding entirely the underlying cedar strands. In the old days, besides these cedar-root baskets, they also made baskets from the bark of the birch, from water grasses, and from netted cords, spun from the bark of the cedar tree. These last they still make and employ, but I saw no specimen of the birchbark kind among them.

The Síciatl had two kinds of bottles for storing their fish-oils, called respectively kwop’t tE laúi and pEáltcis. The former was constructed from the air-bladder or sounds of fish, the latter from the bulbous kelp or seaweed (Macrocystis pyrifera) peculiar to the Pacific Coast. For domestic purposes they used a very singular detergent. It was a kind of tree-fungus, called by 
them Qatkaímōnate, "thunder-excrement." As many of the women use it still, I was able to secure a specimen. In appearance it looks like a lump of dirtywhite under-baked dough; but its strong saponaceous qualities make it an excellent substitnte for soap. ${ }^{1}$

\section{Puberty Customs.}

In puberty rites and observances no two of our Salish tribes seem to follow the same customs. Among the Siciatl the pubescent boy or girl was secluded from the rest of the household for the space of ten days in a cubicle (kówitl), built over the family bed in the interior of the dwelling. The period of a girl's seclusion was always coincident with her first menses; that of the boy was determined by the brcaking of his voice, by the appearance of hair on the pubes, and by the disappearance of the hard, pellet-like substance at the base of the nipple of the mammary gland. If, at any time, the boy or girl desired to leave the cubicle for any purpose, the former was always accompanied by three old men, and the latter by the same number of old women. The occasion of their seclusion was taken advantage of by the elders to instruct them in the several duties and responsibilities of man and womanhood. They were made to eat and drink very sparingly throughout the whole period of their seclusion; the object of this on the part of the boy being to fit him for the privations of the hunter's life, and to prevent him from developing a lustful temperament and interfering with other men's wives. On the part of the girl, it was to prevent her from becoming a greedy and gluttonous woman, who would seek to rob her husband of the choicest portions of their food. To teach them industrions habits the girl was employed in plucking the needles from a fir branch one at a time, or in picking yarn and in spinning; the boy in making arrows and other masculine objects. In order to make sure that the girl drank but little she was supplied with only a shell of water at a meal, and frequently this had a hole pierced throngh it for the purpose of letting the water leak away. Nor must she put even this small receptacle to her mouth, but must suck the water up through a small tube or hollow bone. A girl's first period is ealled qaíEqa, the succeeding ones sqaíEqa. It was customary for the father or nnele of the boy or girl to give a sōlomítes, or puberty feast, at this time to mark the occasion. If no feast were given, their friends and

' Since the above was written, a paper "On the Anatomical Characters of the substance 'Indian Soap'," written by Miss M. Dawson, B.Sc. (Lond. and Wales), and published in the Transactions of the Canadian Institute, has eome into my hands. According to Professor Macoun the substance is a Polyporus allied to $P$. betulinus, which had become changed by its own mycelium into punk. Miss Dawson in summing up her paper remarks, "As regards the nature of this substance, 'Indian soap,' the general arrangement and character of the large colourless hyphe seem to support Professor Macoun's conclusion that it consists of a fructitication of a Polyporus. . . . The whole structure has obviously been much changed by the action of parasitic hyphe, so that we nay perhaps, with justice, conclude that it consists of some large fungus, probably of the Polyporus type, which has been destroyed by two parasitic fungi. . . . As a result, degeneration of some of the interwoven hyphæ seems to have taken place, giving rise to a resinous substance to whose presence the characteristic saponaceous feeling is due." 
relatives would be much ashamed, and feel lowered in the eyes of the rest of the tribe. After the period of seclusion of the girl was over, she was thenceforward treated as a woman. Her parents presented her with a comb and a pair of firetongs, and stones for heating water, and other household utensils, oiled her hair and painted her eyebrows and cheeks after the manner of women.

\section{Mortuary Customs.}

These custons among the Síciatl differed somewhat from those practised by the Halkōmélem tribes.

Dread of the dead was apparently not so strong among them as among the River tribes. The corpse was not taken out of the house, for instance, until the time of burial, usually the day following the death. It was prepared for burial by four or five old men, friends of the relatives. This unusual delay in the disposal of the corpse was due to the fact that these old men had to go apart by themselves, and undergo some ceremonial preparation, before they handled the body. The treatment of the corpse among the Síciatl was similar to that among the tribes already treated of. When ready for disposal, it was usually placed on the open ground on some island set apart for this purpose. Since their conversion to Christianity the Síciatl have gathered up all these old corpses and their remains and buried them in their consecrated grave-yards; somatological material is therefore difficult to secure among this tribe.

\section{Beliefs and Customs.}

The Síciatl believe that the raven foretells the death of anyone. When they see him sitting on the branch of a tree, ruffling his feathers and croaking dismally, they believe that someone among them will shortly die. The old people also say that he gives notice of the approach of a canoe long before they know of it.

When a girl is undergoing her puberty rites she must not eat salmon, or there will be a scarcity of this fish at the next run.

Survivors of dead relatives must never eat salmon in the early stages of the run, nor enter a creek where salmon are found, or the salmon will be harmed. A dead body, or anything in commection with the dead, is inimical to the salmon.

When the women clean the first salmon of the season they must avoid wrenching off the neck. They are permitted to do this only with the later salmon.

\section{Times and Seasons.}

The Síciatl divided their year into twelve portions, which correspond approximately to our twelve months. The moon seems to have held a very subordinate part in these divisions.

The year (Sīlámin) as a whole was reckoned either by summers or by winters, that is by so many tEm éyōs, "fine seasons," or by so many skwómai, "snows."

The seasons (tEm) ale Spring, tEm paifya, Summer, tkm ếyōs, Autumn (vacut), Winter, tFm tcim, "cold season" or tEm sốtetc. 
Past seasous, or years, were thus expressed:- " last year," spénewōtl ; last summer, tEm ếyōs-ōtl ; last winter, tem tcim-ōtl, ete.

The divisions of the year are:-

Jumury, tEm k'aike, "eagle" time, so ealled because the eagle, they say, hatehes its eggs about this time.

February, tEm nEm,

" time when the big fish lay their eggs."

March, tEm sátskai, "budling time."

April, tEm slēm, (from lēm, name of a large migratory bird witl a red breast, and long neek and legs (not identified), which stays about a month in these parts.)

May, tEm tséōntséōn, "The Diver (Loon)," so ealled because this lird begins to make its nest ind lay about this time.

June, tem k'we'Ek'wel, "salmon-berry" time.

July, tem sainq, "red-eap" time (the "red-eap" is a speeies of wild raspberry of this region).

August, tem tâkā, "salal-berry" time.

September, tEm ok'wálenuH, " time when the fish stop ruming."

October, tEm palk-ál'nuн, " time when the leaves fade."

November, tEm qúsētein, "time when the fish leave the streams."

December, tEm kwitó, " "time when the raven lays his eggs."

The Síeiatl seem to have no speeial terms for the quarters as sueh, but speeialize the winds eoming from them, thus: North wind, tolumela; south wind, kainâluk; west wind, tlalīeáluk; east wind, kēeálık.

\section{ArCh Aology.}

The areheologieal remains within the Síciatl boundaries differ in some interesting fentures from those already deseribed in other centres. Speaking broadly, they may be divided into three elasses, viz., midden-heaps, eairns, and fishing works. With respeet to the first, they are to be found throughout the whole territory, wherever a suitable camping ground is found. Some of them are comparatively modern, and of no great extent, and are elearly old eamps of the present tribes. Other's belong no less elearly to a mure remote period, and were formed, here as elsewhere, by raees anteeedent to the Salish. Some of the largest and oldest trees of the distriet are found growing over them, their roots gripjing the midden-mass, and extending throughout it, thus plainly showing that they have sprung up there sinee the eamp was abandoned, which, in some cases, must have been at least half a millenninm ago. These midden-heaps do not differ in any essential features from those already described by me, except that I found none so large and extensive as those on the banks of the Lower Fraser and the shores of l'uget Sound; and as far as my neessarily restrieted examination went, they appear to be rather poor in relies. I seeured a few arrow and spear-heads, some broken slate knives of the creseentie pattern, eharacteristic of this region, an imperfeet pestle-harmmer, and a few other speeimens. The means at my disposal did not permit of extensive investigations. 
Concerning the second class of remains, the cairns, I aln unable to speak positively of the number and extent of these. The natives appear to know nothing of them, or where they are to be found. Those that eame under iny observation are situater on the summit of a mountain overlooking Pender Harbour and the waters of the Strait. This monntain is about twelve hundred feet above sea level. Its summit is open and terrace-like and almost devoid of soil. From the top an extensive outlook may be had of the waters of the Strait. It is very probable that other momtain-tops or slopes in the Síciatl territories contain similar remains.

These structures differ from those found in the Halkomélem territory, chiefly in the fact that they are composed wholly of stone, and in this respect are similar to some of those found on the southern half of Vancouver Island. The preliminary steps in the formation of these sepulchres were the saure as those employed in the formation of the burial mounds or tumuli. An enclosure of varying dimensions was first formed by means of a wall of stones or boulders, set sometimes elose together, at others at some distance apart. This boundary in the Halkomélem area was invariably rectangular in form. On this mountain, on the contrary, it varies from a proximately true circle to an oval. Within the enclosure thus formed the corpse was set down in the middle and covered over with a huge pile of rocks and thus left. It is not easy to estimate the age of these mountain tombs. All one can say is that they are not modern. Such as were examined contained no visible remains of any kind. That they belong to a comparatively distant past is elear from the fact that the morem Indians declare that they know nothing of them, and that their method of disposing of their dead before the advent of the missionary was to place them on eertain of the islets in the inlets and arms of the Strait. This we know they did ; lor the remains of bodies so disposed of have been found on the islands.

Personally I an disposed to regard these mountain tombs or eairns, as I do the tumuli of the Halkomélen area, as the remains of a prae-Salishan people.

With respect to the third class of remains, the fishing works or stations, Síciatl traditions make the Salish enlture-hero or demi-god, QEqEls, the anthor of them. I an unable to say how many of these fishing-stations may be found in the Síeiatl territory; I have knowledge only of that at the montl of a small stream near l'ender Harbonr. This stream drains a chain of small lakes which were a favourite spawning-ground of the salmon, and its moutl lends itself aduirably to the formation of the kind of traps we find here. It is not the ordinary barrier or weir stretching across the mouth of the river which impedes the ascent of the salmon and causes them to congregate in great numbers at the foot, but a series of lateral pockets or traps macke of stone walls at one side of the stream, into which, by a series of channels or flumes, the fish are forced by the tide in their endeavours to ascend the stream to their spawning-grounds. At the ebb of the tide these pockets are praetically drained, and the capture of the fish is an easy matter.

These traps are interesting in themselves as well as from the fact that they 
illustrate admirably the skill of the native races in adapting means to ends. The builder of this fishing station was demonstrably a man of resources and ability, but whether of the Salish stock or of some other, it is now impossible to determine.

\section{Traditions.}

TE SkÉmetl.

The Beaver.

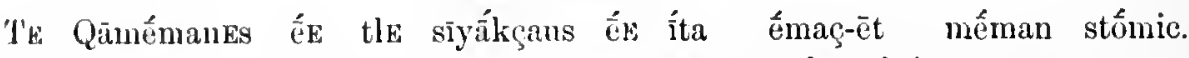
An old-man and his wife-his and also grandson-their young man.

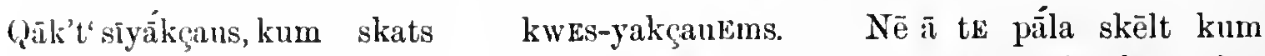
No wife-lis, then desired-he that-he might-take-a-wife. Upon a certain day then tè sō émac tetsét à te stốlō. tē tlálet sốsō, kum tē sóqtas te kwítlēu. he went walking near to the river. lhe continued going, then he saw a smoke. té-tlöms sūs kiwh́tas, tê sớças ótlkai tlestlánai ástūe à te tlumstan, éi he went to-investigate, he saw suake girl inside the house, fine slínai, stōquêt aiyūbic tlấ-tlōm slấnai ôtlkai. Tế-tlōms kwāls tk stómic: woman, exceedingly beautiful that woman snake. He spoke the man:

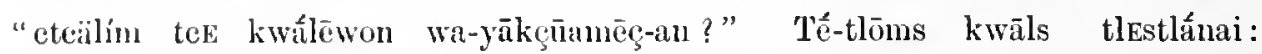
"what you llink if-marly-you-I?" She answers youngwoman: "quī-tean qã-tcanq ne-sqátl-anq, çéçīsōi te kÉlōm, pēk túk·wīlas, "not-I not-you I-like-you, squint the eye, broad belly, kaiakaaikauqauq te iein maistómītein." Tế-tlōms sōs tluk te mếman sliort-arms and feet dislike-you-I." IIe went out the young

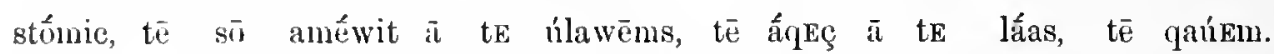
man, he went lome to the house-his, he lay on the bed-his, he cried. Té-tlōns s'wälátèt E-tle sēlas: "etcílím-teñq, émaç?

She asking of-his grandmother-his: "what's-the-matter-with-you, grandson? Ảsuntē qaqawōm?" “Kakayawetlsaim, teiīa——ī, tîtiltel-tōlawōs teiı-kwa, Why erying?" "She-called-me, grandmother, small-eyed I

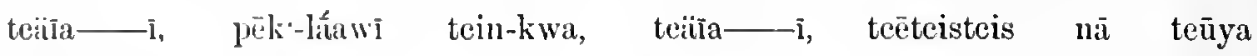
gramlmother, broad-bellied I, grandmother, arms very short tein-kwa-ì-i—-i."

1."

[Wach of these sentences is repeated three times in the story. The youth is supposed to be crying as he utters then.]

Téetlōns qaúkm tle sélas. Nōét-an otlkai hâya She weeps his grandmother-his. "Had-1-been-there-when snake thus-said

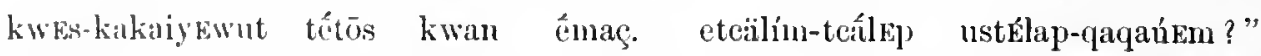
I-woull-have-killed lier my graudson. wherefore-you you-contimne-erying?"

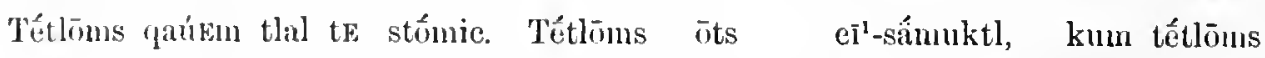

He cries still the man. She calls-up invisible-rain-clonds, then it

- This particle $c \bar{i}$ plays an important part in the Síeiatl dialect. It is used in a variety of constructions. Its ehief funetion is to mark that which is absent and invisible. It is employed here to indicate that the storm eame on suddenly without warning. 
kutu te sámuktl, aiyín eteitl télate. TE stôlō tēséluq te came the rain-cloud, very-heavy rain-storm arose. The river it-washed-away the tlúmstans tle ôtlkai slấnai. tēséluq ótlkai, tē tlalsau-nōmōt Etla house-her the snake woman. it-washed-away (the) snake, she saved-herself by-a sēsitálin sếsia. Tē teat kwāl tle slấnai :- "Aistómē-tein kelaú !" Tē grounded small-tree. She now called-out the woman:- "Love-you I beaver!" He kwāl te kelaú : QQ̄a-tcauq nesqatlauq." Têtlōms k·ốis tle ôtlkai. Kums hốis. replies the beaver: "Not-you I-like-you." She died the sulake. No more.

\section{The Beaver.}

Once upon a time an old man and his wife lived together with their grandson, a young man. He was unmarried and very much desired a wife. Upon a certain day he went out for a walk near the river. He walked on for some time and presently he saw some smoke ascending and went forward to investigate. On getting nearer he perceived a house, inside of which was a young snake woman. She was a very fine woman, exceedingly beautiful was that snake woman. He accosted her thus: "What do you think of the idea of beeoming my wife?" The young woman answered, "I couldn't think of marrying you. I don't like squint-eyed, broad-bellied men, with short arms and feet. Go away, I dislike you." Thus dismissed, the young man went out and started homewards for his own house. When he got there he threw himself on his bed and cried bitterly. His grandmother, seeing him, asked what was the matter, and why he was crying. "Oh, grandmother," he sobbed out, "she called me cross-eyed and big-bellied, and taunted me with my short arms and legs." The grandmother wept in sympathy, and said, "If I liad been there, my grandson, when she called you these ill names I would have killed her. But don't cry any more, I will punish her." Thereupon she ealls upon the invisible rain-clouds. Soon they appeared and a heavy rain-storm arose. The river rose rapidly, and in a short time washed away the house of the snake woman and also the snake herself, who was only saved from immediate drowning by elinging to the roots of a small tree. In her peril she cries out to the beaver, "Oh, Beaver, I love you." Beaver replies, "But I don't love you," and left her to her fate. The water continuing to rise, she was presently drowned.

TE WōkwEnáteEm ìta te StÉmtem.

Tē sō émac te stémtem stetsét ā te kótlkō, tē tlálet sōsō, kum tē He went walking the wren near to the sea, he continued going, then he sóqtas tle kwénis skốīyēt. Tẽ sō tla tas, tEélesōt ā tE kwatámelōms. perceived a whale lying-dead. He went up to it, heclambered on to the side-its.

Tē sélētas tle tlátetEns, tétēlem kwes tē sō émae: "nEsqátl kwens sōqt He searched-for his kuife-his, singing as he went walking: "I wish that-I conld find

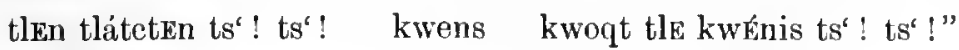

my knife so-that-I-could cut-up the whale."

[This is repeated three times in the story.] 
Kum kEq te skálmīīq, stlumis, nē à tE tā-témīù kānām-et tấsēt tE

Then many the people, crowds, on the other-side (of water) hear-they those the stÉmtEm têtēlEm nē e a te tā-tếmīū tế-tlōms kiwínats-ēt tE snúkQītl-ēt, tē-t]ōms wren singing there on the other-side they take-they the canoes-their, they sōwēt liwe-témīinq, tē sóqtas-ēt tle kwónis. Té-tlōms kwoqsết aukQ, Qāk't' go-they across, they perceive-they the whale. They cut-up all, none s'na tle stémtem. Tē sō te stémtem yélcēn. Kwes tē sóqtas tle tlátctens. 'T'ē his the wren. He goes the wren back. When he found the knife-his. He sō tas a a te sqenés, sōs tle kwÉris, tínyet tle sóçī cau. Tè kwin-nuq. went there to the game, gone the whale, only a tiny bone (was left). He took-it.

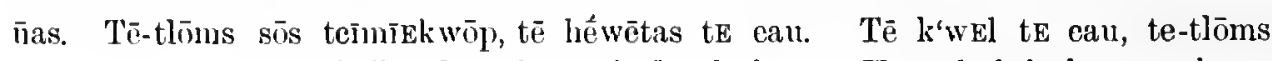
$\mathrm{He}$ went built-a-fire, he put-in-fire the bone. He cooked the bone, he

skómōts. Tè tch́tas Éla tlátetens stesét ā te múksens. Tē tcet-núq-ūas te "mouthed"-it. He cut-it with-his knife-his elose to the nose-his. He cut-it the múksens tē kwutl púlem. Steqwết qútlitl te stémtem, tē nemácae te nose-his it came hanging-down. Greatly distressed the wren, he threw-away the eau. Tế-tlōms kwaiéc, tē sō émảe $\bar{a}$ tr çếtcim, saliakaim te múksEns. Sōs bone. He stood-up, he went walking to the woods, dangling the nose-lis. Going-on tē sóqutas te tcītcím, tê-tlōms sōs tle tas. Tē sóqtas te stómic s'aqaíç stesết à te he perceives a fire, he goes to it. He saw a man lying near to the tcītcím. Tē sóqtem te stémtem tế-tlōms kwāls te stốnie : "é̉mac nE·sīaíya." - fire. He seeing the wren, he says the man: "Walk-forward my-friend." Tấ-tlōm stómic stequêt qus te yéniss. Té-tlōms kwāls tấ-tlōm stómie: "O That man very sore the tooth-his. He speaks that man: " $O$ tE-núwil ne-sīaíya, stequét qus te-nE yénis." Té-tlōms kwetết tle stémtem. you my-friend very sore ny tooth." He examined-it the wren.

Tế-tlōms kwāls te sténtem: "O ne-sīaíya qā winākwes te skwố." Tế-tlōms $\mathrm{He}$ said the wren : "O my-friend not severe the sickness." He

kwāls tE stémtEm "tlatlếñ-sqatlêt tE-nEséna múksEn." Té-tlōms kwāls continues the wren "very-different-matter-to-cure my nose." $\mathrm{He}$ replied te stómic: "O ne-sīaíya qā sqatlátas, laçmả-tcin skwa te múksen." Tế-tlōms the man : "O my-friend not hard-to-cure-it, heal I will your nose." He

sōs te stÉmtem, tē kwínātein tle tlátectEns, tē sō tla-tas te stómic, tē wátatas went the wren, he took the knife-his, he wentover-to the man, he wrenched-out Étle tlítctens te yénis tla stốmic. Tē qaíEm te stómie, tê-tlōms kwaiée with-his knife-his the tooth of-the man. He laughs the man, he stood-up, tE-tenítl, tē sō tla-tas te stémtem, tē kwínātas te múksen tla stémtem, te he, he went over-to the wren, he took the nose of-the wren, he tluk'wamấtas. 'Té-tlōns sōwét ếmēwac. hóis.

made-it-whole. They go-they walking-off. Finis.

The Wolf and the Wren.

Once upon a time, Wren was walking near the beach when he perceived a whale lying dearl. He approached it, and clambered up on one side, and searched 
for his knife to cut it up." Not finding it, he sings to himself, "I wish that I could tind my knife; I wish, I wish, I wish that I could find my knife, so that I might cut up this whale." Now it happened that tlere were a great many people on the other side of the water, and they heard Wren singing his song. Thereupon they take their canoes and cross over to his side. In the meantime Wren goes home to look for his knife. When the people arrived on the beach, they saw the whale and set to work at once to cut it up. 'They took away every bit of it, leaving none for Wren. When he got back with his knife, he found the whale gone and nothing left but a tiny morsel of bone. This he picked up, and when he had made a fire, he roasted it. When it was cooked, he put it into his mouth with one end of it sticking ont. Taking his knife, he sought to cnt it off close to his nose, and in doing so, cut the point of his nose off so that it hung down. Greatly distressed at his mishap, he threw away the bone and started off into the woods with his nose dangling before hin. When he had gone a little way, he perceived a fire, and, on approaching it, saw a man lying near. When the man saw Wren, he cried out, "Come forward, my friend, come forward." Now the man was suffering very much from toothache, and said to Wren, "Oh, my friend, my tooth is very sore." Wren examined the man's tooth and said, "Oh, my friend, you are not very ill. Your tooth is nothing to my nose." But the man replies, "Your case is not very hard, my friend, I will soon heal your nose." Wren then took his kuife, went over to the man and quickly wrenched out the aching tooth with his knife. The man was greatly relieved, got up, and went over to Wren, and taking his nose in his hand, set it in its place, and immediately it became whole. They then separated, each going off in the opposite direction.

\section{Te Sīaíyāk SQáQiam. \\ The Sun Myth.}

Netcấlī Qāmắmanes nī te ménas, temicnálī tE síyalekçaus. ${ }^{1}$ TE swáwelōs One old-man had a son-his, two the wines-his. The youth palát tcátcätetlem. ${ }^{2} \quad \mathrm{KEq}$-álīi ${ }^{3}$ tE skúmakums, kum tlōms ${ }^{4}$ sōs kla tE síya, kum always lunting. Many the companions-his, then he goes to a tree, then tlōms lémetas, tlōms Qấtūks te síya tế-tlōms hōnō̧ōts $\mathrm{tE}$ skúmakums, tē kwấsas he kicks-it, it burns the tree they gather-round the companions-his, it warms tatnénis. Kum tē sō émēwec, tē sóqutasēt te skwếtlai éE te hópīt. Tē all-of-them. Then they go walking, they perceive-they a mountain-goat and a deer. He

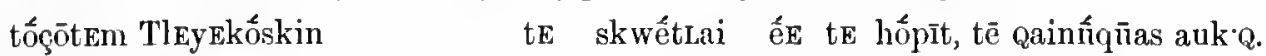
shot (did) Tlkyekóskin (youth's name) the mountain-goat and the deer, he killed-them all.

Tế-tlōms sōs tE skúmakums, yactasēt tE skwêtuai ét tE hốpīt, tē sō

They go the companions-his, they pack the mountain-goat and the deer, they cone (to the) caúwau. Tē kwấtEm T'leyekốckin tle sīyấcins nē ā tE tat-kwát tle stôlō. Tē beach. He left (did) Tleyskóckin his pack-his on the far bank of-the river. He sō améwit ā tE tlúmstans, tẽ tálwitas tE mEns: "Mā, kwố-tciuss-kwātán went home to the house-his, he informed the father-his: "Father (said he), I left tle sīyácin ā te tat-kwát tle stôlō." Tê-tlōms sōs kwaićc te Qāmémanks, tē a pack on the far bank of-the river." He went he-stood-up the old-man, he 
sō ếmac, kwínātas te sīyácins, sōtl te ménas, tẽ yáctem ā te Qāmémanes, went walking, he-took-it the pack-his, belonging-to the son-his, he packing the old-man, tē sō yilcín, tō sótas ā te ónkâts tle stốlō, tē tuk tlúkasas, tē pōks te he goes back, he reached the centre of-the river, it broke pack-saddle-his, it fell the siyácins à te séwōts, tē kwínātas, tē kwínātas, tē kwinātas. pack-his into the water, he clutehes-at-it, he chutches-at-it, he clutehes-at-it.

(The repetition here marks the old man's efforts to recover his pack.)

Kum tē sôtas ā te tlụ séwōts, kwōkwối te qāmếmanEs. Tē kwō-sḱluq ${ }^{s}$ te Then he reached the deep water, drowned the old-man. He floats-away the QāmémanEs, tē kwntL tūa kwóuktlai steqwét éī kwếnktlai, tē old-man, he becaune changed-into a-piece-of-wood an-exceedingly pretty piece-of-wood, he

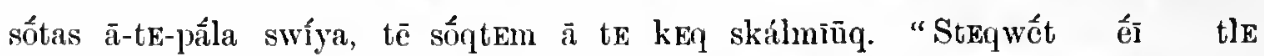
reached another country, he saw there nany people. "Very handsome that kwénktlai," tē kwínātem etle netcâlì slánai, tē çóstwas ā te piece-of-wood" (said one), she took it with-her one woman, she carried-it to the tlúmstans, sótēwon tle slanai: " $\mathrm{nE}-\mathrm{k}$ 'wăst skwa wE-êtltten-an," tē kwutL house-her, she-thinks the womau: "my-plate will-be when-eat-I," it became tlék'wom, kum tē étlten tle slánai, tē kwínätas tle kwéuktlai, tē çēalêtas dark, then she ate the woman, she took the piece-of-wood, she placed-upon-it te sétltens, tē QáQōQ̨e $\mathrm{kmm} k \mathrm{k}^{6}$ ankQ te sếtltens, tē kwínātas tle the food-her, it was-a-little-while then elsewhere all the food-her, she seized she kwếuktlai nemácas, tē sō umkwait tle kwếuktlai a $\mathrm{i}$ te ōnyans te tlumstans, piece-of-wood threw-it-away, it fell down the piece-of-wood in the centre-of the house-her,

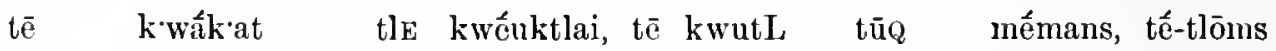
it began-to-cry-like-a-baby the piece-of-wood, it became changed-into a-little-child, she

sōs kwínātas, tē tlótlōtas, mōs skēlt kum tē kwutt tī-stómic, émac tē went $(\&)$ took-it-up, she brought-it-up, four days-only then he became a-big-nlan, walking he

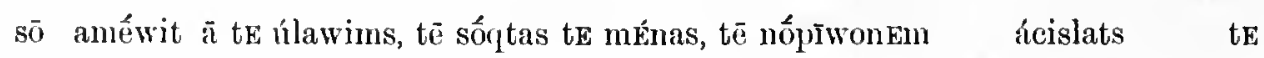
went home to the house-his, he saw the son-his, he uneditates to-take-revenge-upon the menas. T'ế-tlōms sō, kwaiêc, tề sō a te săhnètc te sìya, tē wätc son-lis. He went, he-stood-up, he went to the back-of a tree, he defecates néā-tá-tlōm, tê ótlōtas tle wātc: “ếi kwEs tūQ skwéEkwālkwilác wethere, he instructs his ordure (thns): "Good that-you become little-birds when

kwntlas skwa teEnE-mf́na." Tē sō yū te Qāmémanes, tē taútas te ménas: he-comes shall my-son." He went home the old-man, he says-to the son-his: "MÉna, steq wét ế "Son, exceedingly pretty the little-birds just-now-saw-I in youder tree." " $O$," tē sōt te mínas. Té kwínātas te sluk's ế te haiyaíktans, kum tê-tlōms sōs, he replies the son-his. He took the bow-his and the arrows-his, then he set-out, tē sóqtas tle skwékkwãlwilác, tē tōtsótas ā te haiyaíEtans, kum Q̄i stcalấmus kum he saw the little-birds, he shot the arrows-his, then not able then tōts-núq-ūas, kmm tē sō te síya $\overline{\mathrm{a}} \mathrm{tE}$ kwátam, kum tēe tcat kwin-núq-ūas tle to-shoot-them, then it went the tree up-to-the sky, then he now seized-them the 
skwékkwālkwilác; tēe kwutı

tōe

wate; tē mấtau te tcálics; little-birds; they became transformed-back-to ordure; be shook the hands-his ; tế-tlōms yiltlátcems, kum Qã stcalấnus kum sóqtas cī-qutluk: Tế-tlōms qaúEms he looked-down, then not able then to-see down-below. $\mathrm{He}$ cries;

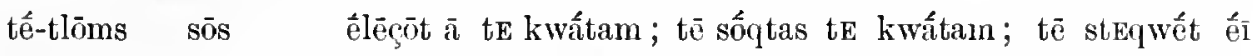
he went-up-to (the) top to the sun-land; he saw the sun-land; it very fine swíya; tē sō émac, tē kánam-nūq-ūas ekwaméǫim, tē sóquitas, tē country; be went-on walking, he heard-it a-knocking-sound, he went-near, he

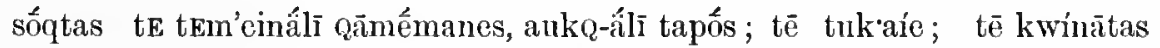
perceived the two old-women, both blind; be sits-down; she takes-it (the food) tē yâtas țe tātkōps ${ }^{7}$; tē kwinätem à tE swáwelōs; tē walasten tle she passes-it-to hel companion; it is-taken by the youth; she asks the QūmémanEs: "Qā-tcūq kwin-nūq ?" "Qā."

old-woman : "Not-you get-it?" "No" (the other replies). She questions the (This incident is repeated three times.)

nEtcálī QāmếmanEs: “Nōwíla émats ?" “e."” Tể-tlōms kwínāts one old-woman: "Are-you my-grandson?" "Yes" (he replies). He takes

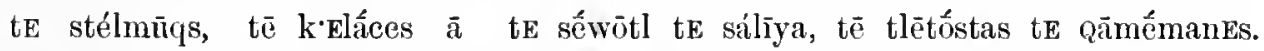
the medicine-lis, he puts into the water the leaves, he sprinkles the old-women. Tế-tlōms skwédans te qāmếmants. Té-tlōns sōs émac tlal te swấwelōs;

They open-their-eyes the old-women. He went-on walking again the youth; tē sốqtas tí-stōlō, $\mathrm{kEq}$ tcálicten, tē kwínātas te skópeins, tē nEmáe as à he perceives a-large-river, many salmon (there), he took a leg-hair, he threw-it on tE swíya, tế-tlōms kwutL spa steqwêt kluk, swênām Etle qaílEm; tē kwínātas the ground, it began-to grow very strong like unto-a line; he took

tE tEm'einákwōm, ${ }^{8}$ tē sō yilācếstwas à te Qūmếmanes, tề saiyūstas à tw two-pieces, he went back-again to the old-wornen, he showed-them the

tEm'cinấkwōm, tē tanitas te Qāmếmanes: "steqwêt kEq tcálieten ā tcE stōlō." two-pieces, he told the old-women : "very many salmon in yonder river." Tế-tlōms snats te QümếmanEs: "nEâtela tī Etle swólten!" Tế-tlōus kwāls tE He bids the old-women: "make this into-a net!" They reply the QuāmémanEs, teēyēmtasēt tE swấwelōs, tế-tlōms kwals te QūmếmanEs: “O, émats, old-women, thank-they the youth, they say the old-women: "O, grandson,

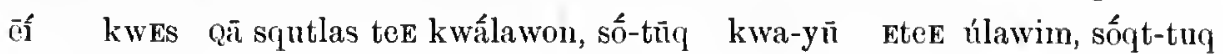
it-is-goorl that-you not sorrow your nind, go-yon absent-home to-your house, see-you

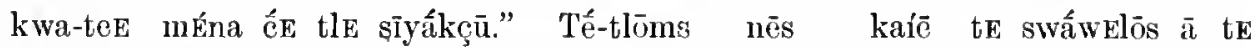
absent-your son \& your wife." He contented remains the youth at the tlumstans te Qāmêmanes. Tē hối te kwēnas skeēlt kum tē kwāl tle QūmếmanEs: house-of the old-women. It passed a few days then she said the old-woman : "Wéyila, émats k’lōm skwa Es-sō yū." Tế-tlōms wek'Et-ét tle "Haste, grandson, now shall you-go home." They opened-a-trap-door the Qāmếmanes te stesét à te tcīteīm-mấlī." Tế-tlōms kwínāts te tí-kâtea, tē old-women close to the fire-place. They take a large-basket, they

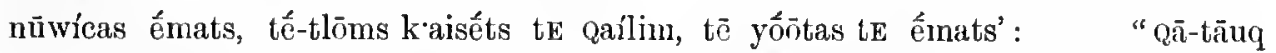
put-in grandson, they fasten-on the line, they warn the grandson (thus): "don't-you 


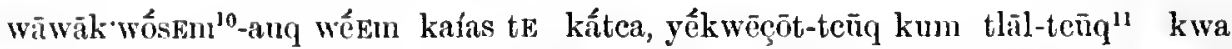
uncover-yourself should stop the basket, just-shake-you then again-you presently sō pélem." Tē tlấlet sōsō kun $\mathrm{kwókm}^{6}$ kaíyē, tēe go-on clescending." He commences to-descend when down-sonie-distance he-stops, he yékwēçōt kum qã ketltas pélem; tẹ wákwōsem, tế-tlōms sōs Emyált à rolls-about but not proceed to-descend; he uncovers-his-face, he (thereupon) goes back-up to te kwâtFm. Té-tlōms ótlōt-ēt, tê-tlōms nuwēyèt tlāl; tē ótlōtas te the sun-land. They scold-him, they put-hin-in-they again; they instruct the énats: "Tó̄ wE-kănam-mūQ-auq cị12-skékīk kum tcat wãkwōsem-teñq." grandson (thus): "Only when-hear-it-you some-crow then now uncover-yourself."

Tè swēnấm stéQas te sQūnâl-ēt Étle sélas. Tē kănanı-nūQ-as tle He like-as did the instructions-their of-his grandmother-his. $\mathrm{He}$ heard-it the skếkāk; kum tē teat wākwōsem. Tê-tlōms sōs yítltwas te kấtca crow, then he now uncovered-his-face. He went running-round-with the basket a tĩ swíya, hối kwố-tlōm sōs cī te kátea. Tê-tións sōs over this country, this-done, that went out-of-sight the basket. $\mathrm{He}$ starts émac te swấwelōs, tē sóqtas tle siyákç̧aus yãcítas te menas; tē kwāl tE walking the youtll, he perceives his wife-his carrying the son-his; he calls-out the mèman: "T'à! tē kwốkwutl te mä." "Tō sōs." "te ma little-one: "Nother: he is coning the father." "Be quiet" (she bids him). "Father kwó-kwulL"ıs tē teat yilklấteEm tle tans, tē sóqtas te swákātss is-coming" (he repeats). She now turns-round the mother-his, she sees the husband-hers tế-tōnss tekaíc, tē kwutL EmEní te swákätss, tē tlals tekaíc stesết étle she sits-down, he comes there the husband-her, he also sits-down close to-the sìyákçaus. Tē élemtas $\mathrm{tE}$ mÉnas tē qaúqanEm; tē wálaçtEm te stốmic tē wife-his. He takes-up the son-his they both shed-tears; he questions the man, he wălatās tle sīyákçaus: "Kwintca tle netcălī nE-sīyākcau?" "Kwo-s asks the wife-his: "Where (is) the other ny-wife?" (She replies) "Long-

wetl swākáç nētl tẹ man kwō̄ ${ }^{x}$-swákātss." time-since married it is your father husband-her."

Notes and Explanations of the T'ext. sìyák gù.

2 tíctcätctlem, iterative reduplication to express the frequency of his action, from tcátlem or tceitctlem.

$=k \mathrm{k} q \cdot \dot{d}(\bar{i}$. This compound is very interesting and shows us that the numeral suffix for. "people" nay be compounded with other than numeral elements, likq being an adjectival promoun signifying nuch or many. Cf. aukq.äli (below in this text) = "both."

"tloms. This form is here given three times without the usual prefix té. This is the more noticeable as te-tloms is so uniformly cmployed. The final $s$ marks its pronominal character. When employed as a simple demonstrative it lacks this inflective element so characteristic of the third persoll. tlom takes several prefixes, the commonest of which are $t \bar{e}, t \bar{a}$ and $l w \bar{o}$.

s $k w \bar{o}-t c i n$. This particle $k w \tilde{o}$ is very interesting in its function. It is the same as the $k w o$ above in the preceding paragraph. When compounded with the pronoun it has a temprial-locative signification. It refers to something that has taken place elsewhere and 
earlier. Other examples of its usage are palât $k w \bar{o}-\mathrm{kw}$ utL $\mathbf{a}$ tE nE-klímstan, "Often he came to my house." Tē kwö-yūtas tcéne-stcédo, "he killed my dog." See other examples in this story.

- $k u \bar{o}$. Here we see another and independent usage of this particle $k w \bar{o}$-Em. Here it takes the verbal suffix.

"tat-kops. I have here translated this term as "companion," but this is scarcely the signification of the compound, kops is the compound term for" "fire," while tat signities rather "across," "on the other side." In the Síciatl tat-kōps conveys the idea of each one sitting on the opposite side of the fire. Cf. the compound tat-kwat in the sentence above ne $\bar{a}$ te tatkwát tle stólo, on the "bank" of the river, that is on the "far" bank. tat-nemis in the sentence above, tē kwasas tat-nenis, it warmed "all of them."

"The suffix seen here is the numeral suffix for long round things.

s -mäliz is a suffix used in vurious compounds with the sense of "place."

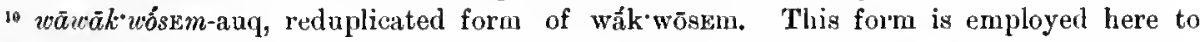
impress upon the youth that he must not keep bobbing up his head to see what progress he was making.

"tlal-tcuq. We have here a good instance of the adverb taking the pronominal inflection of the verb.

$12 c \bar{c}$. This particle always conveys the notion of "remoteness" or "out-of-sight-ness." Cf. sōs $c \bar{\imath}$ tE katca (below), "went out-of-sight the basket."

13 kwō-kwutL. Kwō, as employed in this compound, implies that the father and lusband was looked upon as being "lost." He had vanished from his wife's and child's sight entirely. $t \bar{e} k w \bar{o}-k$ wout $\mathrm{L}$ might perhaps be better rendered by " the lost one is returning."

\section{The Sun Myth.}

There was once an old man who had a son. The youth harl two wives. He was a fine hunter, and often went hunting with his companions. One day, when they were all out hunting together, they got very cold. In order to warm them, he went up to a tree and kicked it. Immediately the tree began to burn, and they all gathered round to warm themselves. When they were well warmed, they set off again on their hunting. Presently they came upon some mountain-goats and deer. The young man killed them all. They then cut up the game and each taking his pack started homewards. When they came to the river, the youth, whose name was TleyEkóckin, left his pack on the bank and went on home without it. When he arrived, he inforned his father of what he had done, and bade him go to the bank of the river and fetch the pack. The old man set out, and, reaching the spot, proceeded to pack lome the meat. As he was erossing the river his paek strap broke, and the pack fell into the water. He made a clutch for it, but failed to secure it; again he tried, and yet a third time, but failed to secure it. By this time he had got into deep water, and the current carried him off' lis legs and he was drowned. He floats off down the river, and as he goes he is changed into a piece of wood. In course of time the piece of wood is carriel into a strange country. There are a great number of people about there, and a woman, seeing the piece of wood took a fancy to it, drew it ont of the water, and took it home with her, saying as she did so: "I will use it for a dish when I eat." At supper-time she took the piece of wood and placed her food upon it; but she had scarcely begun to eat when all the food suddenly vanished. Thereupon she took up the piece of wood and threw it from her. When it fell it began to cry like a baby, and, in a moment, was changed into a little child. She went to it, 
and took it up and nourished it; and in four days the child became a young man. Soon after he set out for his own home. When he arrived, and saw his son, he letermined to take revenge upon him. So he went to the side of a tree and defeeated, and gave instruetions to his exerement in this wise, "When my son comes, I desire that you shall be ehanged into little birls." The old man then went home, and said to his son: "Son, I saw just now in yonder tree some very pretty birds." "Yes," said the son, "I will go and get them." So he took his bow and arrows, and went over to the tree. He shot all his arrows at the birds, but was not able to kill them. He then elimbed the tree, and as he elimbed the tree stretehed upwards into the sky. He presently reached the birds and as he songht to seize them, they turned to exerement in his hand. Shaking his hands to eleanse them, he sought to deseend the tree, but was no longer able to see down below. He wept at his predicament, and proeeeds to the top of the tree and arrives in the Sun-land. It appears to him to be a very fine country, and he sets off walking. Presently he hears a strange knocking sound, and on approaching the spot from whence it eame, pereeives two old women who were both blind. The noise is caused by one of the old women preparing their food. He sits down beside them, and when the old woman passes the food she has erushed to her companion, he intercepts it and eats it himself. The one who had been thus robbed eried out for her share. "Did you not get what I just passed you ?" questioned the other. "No, I have had none." Again the other passes her food, and again it is intereepted by the young man. Three times this is done, and then the old woman who was passing the food suspeeted the presence of someone among them, and ealled out: "Are you my grandson?" The young man replied in the affirmative, and, taking some medieine leaves, puts them in water and sprinkles the old women with the liquid, and thus restores their sight. He then left them, and went on walking. Presently he eame to a large river, in which were many salmon. I'ulling a hair from his leg, he threw it on the ground and immediately it beearne a strong line. Taking the line, he returns to the old women, and told them that the river beyond them eontained lots of salmon, and bade them make the material he had brought into a net. The old women thank the youth, and one of them says to him: "Oh, grandson, don't disturb your mind about your going home; you shall get back all right by-and-bye to your wife and son." The young man eurbs his impatienee, and abides in the house of the old women. Some few days later, the old women said to him, "Get ready, grandson, now you shall go home." Thereupon they opened up a hole elose to the fireplace, and, taking a large basket, bade the young man lie down in it. They then attach a long line to the basket, and instruet the youth in this wise: "When you are going down, if the basket should stop, lon't uneover yourself ; just shake it, and then it will go on deseending again." They then let down the basket, which continues to deseend without any trouble for a considerable distanee, but presently it stops. Forgetful of the old women's instruetions, he uneovers himself to learn what is the matter, but no sooner has he done so, than the basket immediately returns to the upper 
land. The old people scold him for his disobedience, and further instruct him saying: "Only when you hear a crow calling, then uncover yourself and get out; that will be your country." This time he did as they told him, and after a while got to the bottom and heard the cry of the crow. He thereupon uncovered himself, and got out, and taking hold of the basket, ran round with it in a great circle till presently it was drawn up again to the upper regions. When the basket lad gone ont of his sight he set off walking and presently perceives before him his wife carrying his son. The little one recognizes him and cries out: "Oh, mother, here is my lost father coming back." The mother chicles him, and bids him be quiet, but the boy eried out again: "My father is coming." The mother now turns round, and perceives her husband. She sits down, and he comes and sits down by her side and takes the little boy in his arms. They all shed tears of gladness at their leunion. Prescntly the man questions the woman and asks where his other wife is. She tells him that his father had taken her soon after his mysterious disappearance.

Those familiar with the folklore of the Thompson Indians will at once perceive that this story is a somewhat imperfect version of Snikiâp and his son N'tlikcumtem. Throughout the whole story there is a lack of local detail. This, and the several omissions, mark it as a borrowed form. It reached the Síciatl very probably through the Lillooets.

\section{Stcấlisten SQâQēam. \\ Salmon Myth.}

Netcálī méman Qáọaqelēm nē ā te kwôtlkō, kuın tē kwínātem ā tE One little-boy swimming in the sea, then he was-taken by a stcâlisten, tēe nekúmstōm, tē sō tE $\mathrm{E}-\mathrm{c} \overline{\mathrm{I}}^{2}$-tlup, tē sốtas salmon, he dived, he went-down the into-unknown-depths, he saw (the)

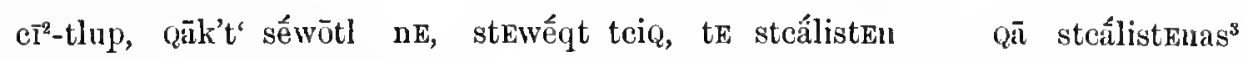
far-bottom, no water there, very dry, the salmon (was) not merely-a-salmon swēnám kwa E-cī²-skálmīūq, tē sō améwitenōm tE méman, tē nē tE mēman like-as some disguised-person, he goes he-takes-home the boy, he is the little

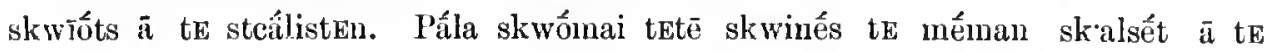
slave of the salmon. One year there stays the boy along-with the steâlisten. Té hố te pấla skwómai, kum tē hốīa te stcấlisten. salmon. It is-finished the one year, then they are-ready the salmon (for quáqawoun te çéçeçōī steálisten. Squạts kwess kwutL the spawning grounds). crying the little salmon. They-desire that-they go

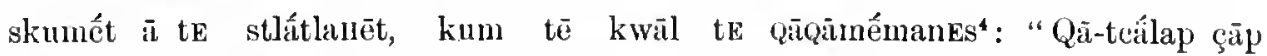
with the parents-their, but they say the old-people: "Not-yon yet skumết, ınōs skwa skwốmai cī²-hốī, kum tcat sō-tcấlap.” Kwénētem ì with-us, four shall-be years yet-eompleted, then now go-you." It-is-seen by te méman te slelâçōts te stcâlisten. Tét-tlōms ōlōçèt à te snukqútl-ēt. the boy the doings-of the salmou. They get-into-they the canoes-their. 
têtlōms kwutL-ēt ā tE stéltōlō, st stEqwêt kwấekwie, keq tE stēlēmāt, they come-they to a creek, very glad, much the singing, (and)

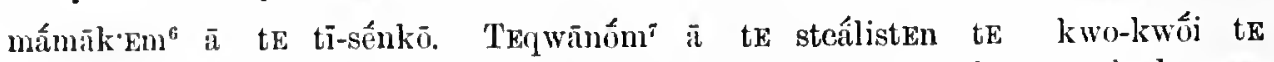
jumping in the big-water. It-is-known to the salmon when dead a

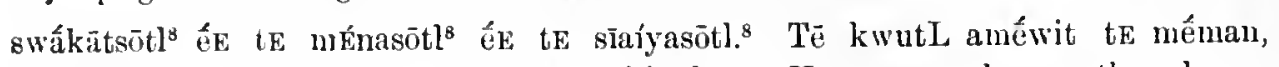
husband or a child or a friend. He comes home the boy, tē taútas te stlatlatlas: “Qã-tcap Hōqsīstap ${ }^{9}$ te steálisten lue instructs the relatives-his (on this wise): "Don't-you break-neck-you the salmon kwes òts kwutL ìmeñ̄ à te stólō." when first come into the river."

\section{Notes and Eaplanations of the Text.}

1 Guxtlkō means the "inner sea" or waters of the channels and inlets in contradistinction to $g^{\mathrm{e}} \mathrm{n} k \cdot \bar{o}$, the sea proper or ocean.

2 See notes on this particle in preceding text.

${ }_{3}$ The animals of the myths are always regarded as different from those now living.

+ Qúquimémunss, rednplicated forn employed here to mark the saying of the several parents.

S StEltootō, diminutive of stốlō, river.

"Mumik $\mathrm{k}^{\prime} \mathrm{m}$, reduplicated to express repetition of action.

- TEqwānốn, to know intuitively without information.

"Suffix of "post" states and conditions, uniformly employed in this mamer in this dialect to mark the "dead" from the "living."

:Hüq-sist-ap, a compound term with incorporated object.

\section{The Salmon Myth.}

A little boy was onee swimming in the sea when he was seized by a salnon. He was taken down into the lower depths and saw the bottom of the sea. There was no water there, everything was quite dry. This salmon was not a common salmon, but a person who eould assume salmon form. He took the boy home with lim, and made him his slave. For a whole year he lived with the salmon. When the year had passed, the salmon got ready to start for their spawning-grounds. All the little salmon began to ery to go too, but the old people remonstrated with them, and told them they conld not go till they were four years old. The little boy observed all that the salmon did, and took note of their lives and doings. When they were ready-to start, they all took their eanoes and made for a small stream. They were a very glad and merry party, and sang and jumped in the water. When the salmon went up the stream into shallow water, the little boy got out and went home and instrueted all the people how they should treat the salmon. They were on no acconnt to break the neek of the salmon they canght in the early days of the run, he told them, or the salmon would never return.

It is believed that the salmon always know when anyone is dead. They will never go near where a eorpse lies. 
Te Kaike ếE te Skaiakenēk:

The Eagle and the ovt.

Pālát tcätcấtctlem tE kaike će te skaíakenēk: QāQai-nūQ-as-êt Always hunting (were) the eagle and the owl. Killed-them-they

tE kEq tītatcélmūūq, steqwét kEq te tlenakwēt ēe te slēuk a a te tlumstanēt. the many auimals, very many the skins-their and the meat in the house-their.

Qāk't sīyákçauēt. NE-ā-te-pâla sk·ēlt kum tē sō émēwec te tem'einấlī (But) no wife-they. One day then they go for-a-walk the two kaiEqnEqwēwes ${ }^{1}$ tlentlấnai. Tè sóqtasēt te tlúmstan, tề sō tek'aíc, young-sisters women. They saw-they a house, they went (and) sat-down, tle tléwēt ā te pâla láas, kum tē sō tle kútī ā-tE-pâla láas. Tè sō the elder on one bed, then she went the younger on-the-other bed. It eame nánat, kum tề kwutL améwit te kaikQ. Tè QáQōQes, kum tê tlāl evening, then he eame home the engle. It was-a-little-while, then he also kwutL améwit te skaíakenēk: Ế te kwálēwon-ēt stemtómic $\bar{a}$ te eame home the owl. Glad the hearts-their men for the

siyâlekçau-ēt. 'Tle kútī sīyâkçans te kaikq; éī méman te ménas. Tle wives-their. The younger wife-his the eagle; fine little-boy the son-hers. The tléwet sīyákçaus te skaíakEnēk; hóham tE snas ména. Tē sō puksátas elder wife-his the owl; (a) frog the her ehild. She went she-put-it

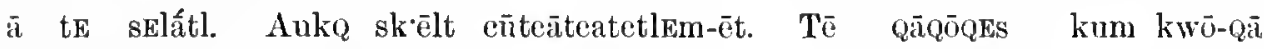
in the lake. Every day hunting-they. It is-a-little-while they not améwitasēt. Slukám tE sīyâlekçanēt. Tế-tlōms sốtīwonēt te slentlấnai : eome-lnome-they. Waiting the wives-their. They think-they the women-thus: "Nêtlya tle sqenám" kwō-Qai-ēt tcems swâlkkats-ôtl." Té-tlōms kwínāt-ēt "May-be a monster. has-killed them our deeeased-husbands." They it-take-they Étla tlếwēt, kum tē yấctas te ménas tle tlālqetal tle kútī. Tè sō of-the elder, then she packs the boy-her she does-likewise the younger. They set-ont émēwke, tē tesmētas-ēt tE sElâtl, tî-lātl, stequét tī-sklâtl. Tế-tlōms kwāls walking, they arrive-at-they a lake, a-big-lake, a-very big-lake. She exelains tle kútī: "Teastūmutc't-kwála kwōms sō kwE-tếmīñ ?"3 'T'é-tlōm the younger: "What-shall-we-do that-we-may get-to the-other-side?" This

sōsōtết Étle teetetas: "ÇōsomteuEt, sō-e’t kwa kwe-tēnūūq." 'Tế-tlōms reply of-the elder-sister: "Be-quiet, go-we presently across." They

kwinàtēt à tle tléwāt th hóham-ménas. Tē yätkáitas à tr qaílem; tē take-they of the elder the frog-son-her. She puts-in-his-mouth a line; she qấetas: "sóla nesím à te tã-tếmīūi ${ }^{3}$ te selátl." QâQōQes kwes tē sōsō bids-him: "go swim to the far-side-of the lake." Presently when he is-going tle hớham kum titaíyak: Tè yilićńn; tē tcéyitenı à te slaktlas." the frog then gets-angry. He turns-round; he is-encouraged by the mother-and-aunt. Tế-tlōms sūs tlāl. Tēmtlālt à tă-témīñ. ${ }^{3}$ Tlé-tlōms tlaúitsēt tlè He starts afresh. They-arrive at the-other-side. They behind-leave-they the 


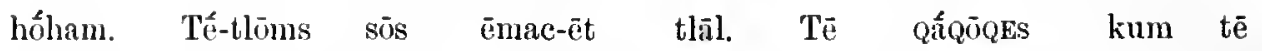
frog. They set-off walking-they again. It is-a-little-while then they kánam-nūoasèt eî-Qálōkōm. 'Té sóglasēt te tlumstan; tē sō ôtōtūQ; hear-it-they a-strange-noise. They perceive a house; they go into-the-house; tê sốquasēt te swálkkatsêt sōaqai. Qáōōess kum tē kwntL ênā they see-they the husbands-their in-a-dying-condition. Presently then she comes there tle Yanēqếmēkwon. Tè qaíkm; tê-tlōms kwäls: "Mēwêla! sō-e’t kāksém." the " . She laughs; she says: "Come! let-us-go play."

Tếtlōns sówēt. Tè kwômōtem ā tle tlêwèt te temtl ế te skwōq.

They gro-they. It is-placed-in-mouth by the elder the red-paint and the white-paint.

Té yấtas te ménas à te qaílem. Té-tlōms sōs qaiaqaíçoot. Tē pkktas te She gives the boy-her a line. They start sliding-down. She spits-ont the tentl ếE te skwōq. Tè qaíEm tle Yanēuémēkwom; sótēwon kwesred-paint and the wlite-paint. She laughs the " ; thinking that-

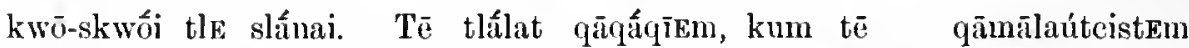
she-is-killed the woman. She keeps-on sliding, then she touched-her-on-the-shoulder.

[The younger sister repeats the same triek.]

Tè kwāl tle Yanēqémékwon: "StEqwêt ếi te mākến-elap,
She says the
tcatcastoteElap?" "Thīt-e't kutlkwat tE kwelétl ét tE kwās qaíels, how-make-grow-you?" "Put-we on-the-crown some pitch and some hat stones, tlōns kwutL pā tEms mấkēn." "Hútas tōn'céla!" thereupon comes growing our hair." "Do-it to-me!" (she demands). Té-tlōms Hútas-tówēt. tē nī, tle netcálī, à te kwílas, kum tē nī, They set-about-it-they. She (standing) by, the one, the belly-her, then she by,

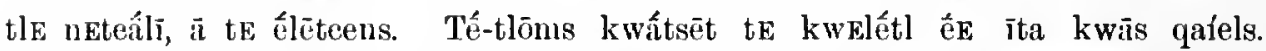
the other, the back-her. They put-they the pitch and also hot stones. Tē yásētas te-suas mákēn, k’ākeklnantas. Tē kwāl tle sQknám: She throws-forwart her-own hair, she-is-befooled. She calls-out the witch : "Un-nun-na! qus-tean." T'é ótlōtem káīye. "Tè wEtl-kwutL pā te "Oln!-Oh!-Oh! sore-I-am." She bid-her be-quiet. "It is-coming to-grow your mákkēn." Tê tlálat skwinết kum tē kwố. hair." She again cries-out then she dies.

\section{Notes and Explanations of the T'ext.}

1 Kaisq-nEq-wẽ-wes. This is a synthetic term of relationship very difficult to render into English. K'aikq is a word nsed to designate a younger brother, sister, or consin. $N \mathrm{E} q$ appears in terms which express relationship to one's wife's people as : nEq-tcñmáicten $=$ wife's brothers and sister's, $n \mathbf{E} q-2 r \bar{e}-n \mathrm{Em}-t \mathrm{E} n=$ wife's relations generally, and the latter elements of the compound are seen in the term for "youths."

"SqEnám. The nse of this term in Sficiatl is very interesting. It is the term for "Doctor" in the Halkōmélem and Sk 'quōmic.

${ }^{3}$ Kwe.témlūq, ef. with this tã-tếming below. These prefixes are locative particles with meaning similar to the cis-and truns- of the Latin.

- There is no equivalent for this term in English. Both mother and annt are equally sluktlas. 


\section{The Eagle and the Owl.}

Once upon a time Eagle and Owl lived together in the same house. They were great hunters, and always had a goodly supply of neat on hand; but there was one thing that they both lacked and that was the possession of wives. They were both wifeless. Now it happened one day when they were off hunting, two young women, sisters, in one of their walks eame by where Eagle and Owl lived, and seeing their honse went into it. On entering they pereeived that it contained two beds, and the elder sister straightway appropriated one of these, and the younger the other. A little after sunset, Eagle and Owl returned from their hunting and found the young women there. They were delighted to see them and each took one to wife; Eagle choosing the younger and Owl the elder sister. In due course of time each woman gave birth to a son. To the younger was born a fine male chill, but the offspring of the elder was a frog, which the mother placed in the lake as soon as it was born. Eagle and Owl continued their hunting and went off day by day into the woods as before. One day they failed to return when night set in. The sisters waited day after day for them, but they came not. Said one to the other, "I fear some dreadful monster has killed our husbands, and they will never return to us more." At last they determined to wait no longer for their coming but go and search for them. So they set ont together, each taking her child with her. When they had been walking for some time they came to a very broad lake, and the younger said to the elder, "How shall we ever get across?" "Oh, don't you worry about that," was the response, "we shall get across all right presently." And as she spoke she took a long line and fastened it in the month of her frog-child like a bit, and instructed him to swim before them across the lake, while they would follow after walking on the line. When they had gone some way in this manner the frog-boy grew restive and stopped and turned round; but his mother and annt soothed and enconraged him and he set off again, and in comrse of time they all reacher the other side in safety. Here the women left the frog at the edge of the lake and set off walking again. When they had been travelling for some time they heard a strange noise and perceived before them a house. They enter this, and find their husbands there at the point of death. Presently the witch-monster, whose horse it was, came home and foumd them there. Her name was Yanēqēmēkwon. She grins when she sees the women; and, in order to destroy them, proposes that they shall play at sliding down the monntain. Now this momtain, after a short declivity, falls abruptly, and precipitates the venturesome slider into a yawning chasm, hundreds of feet below. Thus the witch-monster thought to rid herself of the wives of her vietims. But the elder sister took the magic line she had nsed in crossing the lake, and, fastening one end about herself, gave the other to the little boy to hold. She also, the better to deceive Yanēqēmēkwon, put into her mouth some red and white paint. After that, she started to slide down the mountain side, and as she vanished over the edge of the chasm, she spat ont the paint which 
she had in her moith. The witch-woman, perceiving this, believed it to be her brains, which had been dashed out in her fall. Thereupon she laughed a hideous langh, but even while she laughed the woman returns, brought back by the clastic strain of the magic rope, and tonches her on her shoulder, and she perecives that her scheme has failed. It is now the younger onc's turn to slide. But she does the same as her sister; and when the witch is laughing in glee over her supposed death, she in like mamer is drawn back, and to the witeh's astonishment, stands by her side unhurt. Yanēèmèkwon is now struck with the long glossy hair of the two women, and openly admires it, asking them how they make it grow so luxuriantly. It is now the sister's' turn to deceive. So they reply that the abundance of their tresses is the result of their putting pitch and hot stones on their heads. Yanēqēmēekwon requests them to treat her hair in like manner for her. They consent, and set about doing it, the one standing behind, and the other in front to hold her down. They cover her head with pitcl, and then place burning stones upou it; and the woman behind brings forward her own hair and lets the ends hang down over the witch's face in order to induce her to believe it was her own hair growing. The pain of the burning pitch and stones makes Yanēqēmēkwon struggle and cry out, but the sisters hold her down, bid her keep quiet, and declare that her hair is beginning to grow. The increasing pain makes her struggle and ely out again, and she would fain have rid herself of the cause of her agony, but it is too late now, and she presently expires.

TE AsQ éE te Skwátō.

The Seal and the Raven.

Te skwátō nē tle ális asQ. Tē sō te skwátō ólōtl ā te smukqítls. Té The raven laal a sister seal. He went the raven into the canoe-his. He sō tas $\bar{a}$ te skwinếs tle ális. Tē neúmtem à te sếtltens. Tē went there on a visit-to his sister. She prepared some food-her. She

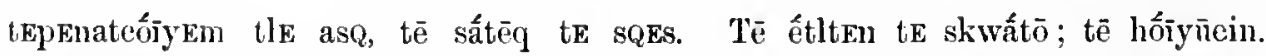
roasts-her-hands the seal, It drips the oil. He eats the raven; he is-satisfied.

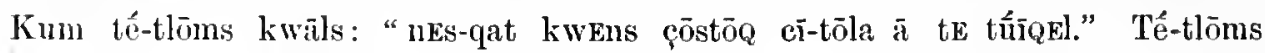
Then he says: "I-desire that-I adopt one of the family." She kwāls tle asq: "ếi nētl skwa tle kéek̉tī sóswauq." Té-tlōms sōs te replies the seal: "good it-is slall the youngest go-with-you." $\mathrm{He}$ went-to the

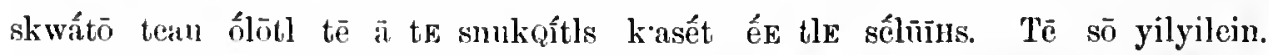
raven beach into he the canoe-his they-get and the nieee-his. They go back.

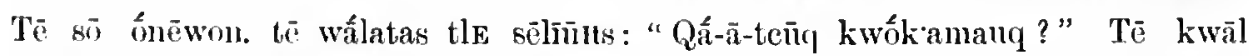
He went lalf-way. Ife questions the niece-his: "Not-yon thissty-you?" She answers lle méman: "Kwōkan-tcin." Tế-tlōms tlấlie te shwâtō. Tē tékōn. the little-girl: "Yes,-thirsty-I-am." He pulls-ashore the raven. They jump-out. Tō k'Elósem tle méman tê sitéakwatem $\mathrm{k} \cdot \mathrm{lk}$ skwátō. Tē kwốnōm She stoops-to-drink the little-girl she is-struck-on-the-head by-the raven. She is-killed k’le skwátō. Tè ólōtl thas à te suukqítl; kum tē sō yū. Tē sō by-the raven. He puts her-into the canoe; then he goes home. He arrived 
amếwit. Tè tlaácin à tle sélīñsōtl. Tè aukQ Hútas-tūas

home. He feasted on his deceased-niece. He all did-the-same-to every-ane-of

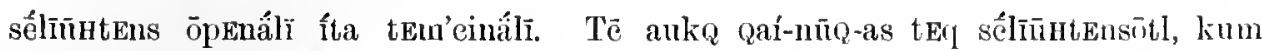
nieces-his ten and two. $\mathrm{He}$ all killed-them all nieces-his-late, then

tē teat sō mē tas tle ális. Qats tlāl kwes-kwósyyūts. Kum tē qū he now went came there his sister. Desires-he also that-he-may-kill-her. Then he not

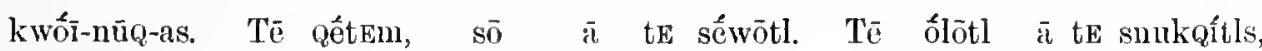
kill-her. She jumps, she-goes into the water. He gets-into the canoe-his,

kum tē sō yū. Mai stómic te skwâtō, steilteilốtl, kwōkwớQals, kEq then he goes home. Bad man (is) the raven, always-stealing, always-nurdering, big Éwon. KEqấlī te sīyắlekçaus. Tẻ taiyākemítem ā te QEqals, tē aiyuwatem, liar. Many the wives-his. He makes-angry Qeqals, He is-transformed, tẽ kwutL tīe qaíels ếE tle sīyákęaus. Hồi.

he becomes elianged-to stonc and the wife-his. Finished.

\section{The Seal and the Raven.}

Raven, who lived in one part of the country, had a sister named Seal, who lived with her large family in another part. One day, Raven determined to visit his sister; so taking his canoe he set ont. Upon his arrival, Seal set about preparing a meal for him. She did this by roasting her hands before the fire and eatehing the oil from them as it dropped into a dish. When Raven had satisfied his appetite, he told her that he desired to adopt and take home with him one of her ehildren. " Very good," replied Seal, " you shall have my youngest daughter." In a little while Raven set out for his home, taking his youngest nieee with him. When they were about half-way there, Raven asked his niece if she were not thirsty. She replying in the affirmative, he pulled ashore. She got out of the canoe and stooped down to drink. As she was stooping, Raven struek her on the head and killed her. He then places the dead body in the eanoe, and makes straight for his home. When he arrives, he holds a feast and devours the body of his niece. In like manner, he got possession of all his nieces, twelve in number; and devonred them in the same way. When all his niees had thus been disposed of, he makes up his mind to kill and devour his sister Seal; but she is too clever for him. When he attempts to kill her, she jumps into the water and gets away. Thus defeated in his purpose, he has perforce to return home empty-handed. His many crimes and wickednesses shortly after so incensed the Sky God QEqals that, to punish him, he turned both him and his many wives into stone.

\section{A Siciatl Prophecy.}

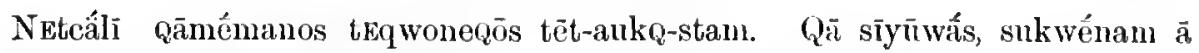
One old-man foreknew everything. Not shaman, same-as a cī-"prophet." kwéakwōkwāl ā eĩ-kwắtem. Çốçōt nētl cī-kwấtemprophet. Always-speaking abont the-nnseen-world. He-tanght it was the unseen-sky sấtlam. Tē uEất tốmōsōtl. Neti tê neất-ōtl tet-ankQ-stam. TeqwōnéQōs power (who). He made the-ancients. It-was he made every-thing. He forekuew 


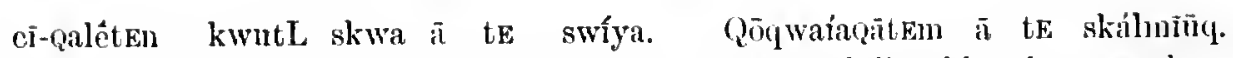
far-off-white-man come will to this country. He-was-disbelieved by the people.

Nfétem kwes keq aíwons. Teqwonéōos te cemán kwEs kwutL skwa It-was-legarded as big lie-his. He fore-told the warriors that come shall qaîlè̃]. to-fight.

\section{A Sürixull Prophecy.}

There once lived an old man who was able to foretell everything that was going to happen. He was not a shaman but a true prophet. He was always speaking to the people about the other world. He tanght them that it was the unseen Power above who made the aneients and that $\mathrm{He}$ had made everything they saw. He foretold of the coming of the unknown white men to this country. The people did not believe him; they regarded lis statements as great lies. He also foretold of the coming of their enemies in battle.

NorE.-My informants told me that this person lived some generations ago before the coming of the priests.

\section{Tradition of a Great Sinoustorm.}

The old pcople of long ago tell a story of a severe snowstorm. So deep was the snow and so long did the storm continue that the people died in great numbers from lack of food. Only the very wealthy were able to procure food at all. To such a pass were the poorer people driven that they not only ate their dogs and everything else they conkl lay their hands on, in some instances their very children.

This story would appear to be based on actual facts. The tradition of a fearful and prolonged snowstorm is common to most, if not to all, the tribes of this region; and a similar story is recorded with much graphic detail by the old people among the Squamish.

\section{The Thresher Myth.}

Te Stálacin SQāQiam.

Once upon a time some of the people of the village perceived a sea-otter (Keltêtr). They hastened to take their hows and arrows and shoot it. The ntter was struck in the tail with an arrow and captured. It is given to the man who slot it, and he kills and skins it. As there was mueh blood on the hair, he left the skin soaking in the water and told his wife to go and wash it. When the woman had cleansed the skin, and was washing the blood from her hands, it floated a little way out from the shore. Upon seeing this the woman pulled up her skirts ancl went in afier it; and just as she put her hand upon it, the skin jumped up and caught the woman in its arms, being ehanged at the same moment into a thresher (Stâlacin). Immedintely the surrounding water was full of threshers. When the husband learns what has happened, he becomes very angry. $\mathrm{He}$ paints his face with black, white, and rerl paints, and puts a large quantity of eagle down upon his head. He then takes his spear and harpoon, gets into his 
eanoe, and goes after the threshers. When he approaches they all dive. He waits for them to eome up again, but they do not come. He goes out a little further on the water and drops his anchor. He then takes off all the down on his head, and dives into the water after the threshers. When he gets to the bottom he finds a very fine country down there. Perceiving a road he set out to follow it, and presently comes to a house. When he gets close he sees a crane. It flies away crying, "ka, ka, ka!" as it goes. "Shut up, grandmother," said the man, "I want to talk with you." The erane then stopped, and the man asked her if she had seen a woman pass that way with the people. "Yes," replied the crane, "I saw a woman just now with some people going by here." The man proceeded on his journey, and presently sees in the distance the smoke of another dwelling in the centre of a fine valley. When he came to the house, he saw a wild goose there. The goose was erying out after its kind, and the man bade it be quiet. "Shnt up, grandmother," says be, "and tell me have you seen a woman pass this way?" "Yes," said the goose, "she passed by here just now." The man goes on here again, and, in a little while, perceives before him the smoke of another" dwelling. Upon reaching it, he sees that it is inhabited by a slēm (aquatic bird not identified). It also was making the noise peenliar to its kind. "Shut up, grandmother," said the man to it, "and tell me have you seen a woman pass this way ?" "Yes," said the slēm, "she passed by here just now." The man goes on a little further, and then, by his magie power, compels the slave of the Thresher to go out and gather firewood. As the slave approaches the spot where he is, he ehooses a good tree, and gets inside of it. Thus hidden, he draws the slave to him. When the slave eame to the tree, in which he was hidden, he took his stone chisel and hammer, and began to ent it down. When the slave drove the chisel into the trunk, the man inside opened his month, caught the chisel in his teeth, and broke it. When the slave perceives that he has broken his chisel, he sheds tears at its loss. The man now comes out of the tree, and, revealing himself, said to the slave, "Give me your broken chisel, and I will make it whole for you." The slave gave him the pieee of ehisel, and the man put it in his mouth, and by his magic joined it to the other piece, which he still retained in his mouth, and made it perfect as before. The slave is very grateful to the man. The latter now asks the slave to help him get his wife back from his master. This the slave consents to do, and they plan together how they may outwit the Thresher. The slave chops down the tree, and the man, taking a piece of the wood, hides himself within it by his magie power, and instruets the slave to earry it home, and put it down just inside the door. It is arranged between them that after the slave has made a big fire to enable the man to see all over the house and where his wife has been placed, he shall go to get water, and when he passes by the fire, shall pretend to fall down and spill it all ovel the fire. Upon arriving at the Thresher's dwelling, the slave set down the piece of wood containing the man just insicle the door, as had been arranged between them, started a large fire, and then went out to fetel some water. In passing by the fire on his return he stumbled and fell, casting 
the water on the fire, and leaving the room in darkness. The man thereupon jumped out from his hiding place, caught up his wife and ran away with her, while the slave busied himself in starting the fire anew. When the light of the fire is cast over the dwelling the Thresher and his friends perceive that the womm has got away. They all start off to pursue her, the slave going with them. Now the slave was by far the swiftest rumner of them all, and, coming first to the runaways and wishing to aid them, he pretends to fall down, and where he fell there immediately sprang up a lofty mountain between the man and his wife and their pursuers. By the time the latter have climbed the mountain, the former are well on their way, but before the man can get to the spot over which his canoe is moored they are upon him again. The grateful slave again came to their rescue, and raised a second barrier between them and the pursuers by casting himself on the ground as before. Before the Thresher people conld cross this second mountain the man reached the line hanging from his canoe and jerking it violently is pulled up to the surface with his wife in his arms by his brother who is waiting in the canoe for him. They immediately pull for the shore and only just reach it in time to escape the angry threshers, who, as soon as the fugitives got to land, gave up the chase and troubled them no more.

\section{The Eagle People.}

There was once a chief who had many wives. In his tribe there was a great number of young men. Now one of these youths fell in love with one of the chiel's wives. She was the most beantiful of them all. At first she would take no notice of lim, but, in the end, she yielded and spent nost of her time with the young man. When the chief learnt of his wife's infidelity, he sought to find who her lover was. To do this, he laid a trap for him. He sent out a number of men to collect pitch. This he spread over his unfaithful wife's bed, and the following night when the young man went to visit her he laid down on the pitch, which adhered to his back. When he essayed to get up in the morning, he found limself held back by the pitch; and, in order to get up at all, was obliged to go away with the bed-board sticking to his back. The chief was looking for this, and had the young man seized and thrown into the water. When the youth found himself in the water, he prayed to Qkqals to save him. The sky-god heard his prayer, and ealmed the water all around him. For ten days he floated with the tide, with the board still fastened by the pitch to his back. By the tenth day, the heat of the sum had so melted the pitch that he was able to rid himself of the board. $\Lambda$ little while after, he found himself on the other side of the sea and drew himself ashore. He felt very sad and cried very much at the thought of his lonely endition. He threw himself on the beach, and covered his face with his blanket. 'Thus he remained for a long time. When the sum was well up, and he was feeling a little better, he felt something tonch his feet and looked up quickly to see what it was. Seeing nothing, he covered up his face again. He had no sooner done so than he felt the touch repeated. He raised his head a second time and looked 
lound, but nothing was visible, and he covered himself a third time. This oceurred many times; at last, feeling sure that somebody was playing him a trick, he set about discovering who it was. Instead of wholly covering his face, he so wrapped the blanket about him that he could peep out all the time. Presently he perceived a mouse come out of a hole near his feet. "I see you, Monse," he cries, "you meedn't hide any more." Mouse now stays and, sitting down by the young man's side, asks where he had come from. The youth replies, "I came from the other side of the water; Káo threw me into the sea and I floated here. But where do you live?" Mouse replies, "We have a house over yonder. Many young women live there. I am their slave." Now the young women had seen the youth, and had sent Mouse to him; and, although he could not see them or their dwelling, they were at that very moment peeping at and discussing him. One said, "I will take him for a husband." Another said, "No, you sha'n't, I will have him ;" and so said all of them. Mouse now brings the youth to the house. When they got in, he perceived a number of girls sitting down in a line. Being a fine-looking young man, the women all admired him greatly and each desired to possess him for herself. He sits down before them, and the first woman asks him, "Will you take me for your wife?" Beforc he had time to reply, each of the others made the same request. The young man would have been greatly enbarrassed if Mouse had not forewarned him of what would happen. "Refuse them all," he had told him, "exeept the last one. Take her for your wife; her father is a very rich man." Acting on Mouse's advice, he chose her for his wife. As they talked together, she said, " $\mathrm{My}$ father will come to-morrow and offer you your choice of two eagles, one the black, the other the bald-headed eagle. Choose the black one. I will take the white-headed one for myself." Next day the old man came, and did as his daughter had saicl. His wife now instrueted him to put on his eagle's skin. She did the same with hers. "Now, I will teach you how to fly and eatch fish," said she; "only be eareful to follow my instruetions. There is a monster who floats on the water. Don't be tempted to eatch him, or he will lead you to your death." He beeomes a very successful fisher, and secures all kinds of marine game such as salmon, porpoises, seals, and whales. So excited is he with his sport that he forgets all about the monster. Lyiug on the surface of the water, he sees in the listanee what looks like a large fish. He flies towards it, and fastens his talons in its flesh. Just as he does so, his wife perceives what he has clone and the great danger he is in, and flies to his resene. He was in the power of the monster. The ereature now encleavonrs to llag him uncler the water, and when his wife reaches him, only his head is visible. She seizes him hy the hair and calls to her father and brothers and other relatives to comc and help. They hurry to her aid and many other eagles also lush to assist. They struggle together for a long time, but, in the end, the eagles win. The monster is torn asunder, and the youth carries the portion he held ashore. They all rejoice at their suceess, and talk of his wonderful escape. When a year had passed by, a son was boru to him. As soon as the child began to speak, he eried 
incessantly for his patemal grandparents. 'This makes the father desire greatly to get baek to his own home, but knowing how far away across the water it was, he saw no hope of ever reaching it and became very sacl in consequence. When his father-in-law (Swénkm) perceived his sorrow, he said to him, "Son-in-law (Stcenitas), don't be downeast: you shill go baek to your home by-and-bye." The next day his father-in-law took a small canoe, and, plaeing a carved fignre at each end, placed his son-in-law and his daughter and her child in the centre of it. $\mathrm{He}$ then pnshed the canoe into the water, and said, "Go, carry them home." The canoc thereupon went of itself. There was no lack of food for the jomrney, for the old man harl given them a magie glove full of choice meat which never got empty. In course of time, they crossed the sea and reached the village of the young man. It was night and very dark when he arrived, and no one knew that he had eome. But next day, it soon beeame noised abroad, and everybody came to see him; above all, the young women of the village. They all desire to have him for their husband, but he declines all their offers. Next day he gave a great feast. His wife opened the glove in which their food was stored and took out what was left. It filled two houses. He now cooks it, and by his father-in-law's magie, is able to boil this vast quantity in one small kettle. He now invites all the people of his village to share the food with him. When they are assembled, one of the guests, whose name was Raven, makes fun of the small pot in which the food was cooking. "Somebody" will go short," said he, "if that is all you have to offer us. I conld put all that pot holds in my own spoon." The young man and his wife say nothing, but take three small dishes and pour the meat into them and ask the people to help themselves. This, with much serambling, they did, and to their surprise the dishes ever remained full. Raven tried hard to empty them, but found it beyond his power. However mueh was taken ont, more remained behind, nntil everybody was satisfied. When all were filled, then the pot was empty.

When their guests had all gone, the wife says to her husband, "Now you must be very eareful and not go with any other women. If you are nufaithful to me I shall go away and leave yon." On the following lay, his wife wanting some water, he took a bucket and went to the ereek to feteh her some. When he got to the creek, all the girls in the village were there on the lookout for him. One of them enticed him to go into the woods with her, and he, forgetful of his wife's warning, accepted her invitation, and went with her. Some time later, he returned to his home with the water. When he sets the water down, his wife takes an eagle quill anl, dippling it in the water, holds it up and examines it. By this means she learus of his infidelity. She throws away the water, and will have none of it. Saicl she to him, "You have broken your promise to me. Now I must leave you." So saying she took her child, and went down to the beach. He follows her, and besecehes her to turn back. She does not stop, but vids him go home and leave her, saying as she went, "If I turn my face towards you, you will die." When she got to the water, she did not seek her eanoe, but walks straight on, and the water supported her. He follows close behind her, in like manner the water also 
supporting him. Again he begs her to return with him, but she answers, "Nay, I can return no wore; but go you home." He replies, "I will never leave you," and continues to walk after her, beseeching her, evcry few steps, to stop and turn back with him. Thus they coutinue for a long way; and she, at last weary of his importuning, turns round towards him. Immediately the waters cease to hold him up and he sinks beneath them and is drowned.

\section{The Mink and the Wolf.}

Young Wolf one day went out hunting. When several days had passed, his friends thought he must be lost, and went to look for him. In the meantime, Mink went down to the water to fish. As he sat in his canoe fishing, he saw Young Wolf on the beach. Wolf calls to him to come ashore, but Mink pays no attention to him; Wolf, however, continues to importune him, and Mink presently pulls ashore and takes him into his eanoe. When he is seated, Mink asks him if he likes sea-urchins' eggs: Wolf replies that he does. Mink then bids him help himself, saying, "Eat as many as you like, but eat only the white ones, don't eat the red ones." Wolf falls to and devours a great many. When he had finishel, Mink says, "If yon want to go to sleep now, lie down in the bottom of the canoe and rest your neck on the thwarts." Wolf does so, and is soon fast asleep. Presently, Mink takes his knife, and cuts Wolf's throat with it so that he dies. He now pulls ashore, skins Wolf, and takes the pelt home with him, and hangs it by the fire to dry. A little while after, Wolf's grandnother came to Mink's house to buy sea-urchins' eggs. Mink tells her to look at what was hanging before the fire. She looked up, and saw her grandson's skin, at sight of which she cries bitterly. Said Mink to her, "If you want to make that noise you had better go ontside, I don't want you blubbering here." The old woman thereupon left the house, and went home. "What are you crying for?" said Old Wolf and the others. She answered them, "I am erying beeause I shall never see my lost grandson any more; Mink has killed him." When they hear this, they beeome very angry, and declare they will go and kill Mink; but one says, "Don't let us kill him in his own house, but let us get him here and kill him." In order to entice Mink to their house, Old Wolf gave a great potlatch, and invited everybody to attend, Mink among them. Now the Mink suspects some trick will be played upon him, and that the Wolf pcople will try to take revenge for the murder of Young Wolf; so he takes steps to ontwit them. Now Knothole was his grandmother, likewise Mouse, and he gives them instructions in this wise. To the former he says, "If the Wolves spling at me, you grow big and let me through." To the latter he says, "You gnaw all the bows and paddles of the Wolf people so they cannot use them without breaking." They promise to do as he bids them. When Mink reachel the Wolves' house, and was fairly inside, they all sprang upon him with the intention of tearing him to pieces, but Mink, being on the lookout for this kind of welcome, sprang through the Kuothole, and ran down to his canoe. The Wolves seized their bows and arrows, and essayed to shoot him; but as Monse had 
bitten each bow almost in two, their weapons broke in their hands. Seeing this, they threw them aside and rushed to their canoes to follow after Mink on the water. No sooner are they fairly started than their paddles snap in two, and Mink gets away from them. But the Wolves are determined to take him, and get new paddles and retmrn to the ehase. After a long pull, they overtake and capture him, and would have bound him with cedar withes, but Mink said to them, "It is no good tying me with eerlar I can easily break that. You had better take a kelp line and tie ne with that." This they did ; then Mink said, "Let me dance before you kill me." "Very good," they answered, "you shall have your dance." So they bring the canoes together, side by side, and Mink begins his dance. He dances first in one canoe, and then in another. Then he puts one leg in one eanoe, and the other in another, and bids them separate the canoes a little. "Now elose up again," he say's, "now open wider." When the canoes are well apart, he suddenly jumps into the water and dives down between them. The Wolves search everywhere for him, but cannot find him. Presently Mink pops his head up out of the water, near the shore, and cries out, "Hullo, you people, what are you doing there?" The Wolves pull ashore after him, determined yet to kill him. Mink now enters a hole, and the Wolves come and thrust their spears in, hoping to kill him; but again Mink ontwits them. When they thrust the spears in, he takes some of his grandmother's guts and put them on the spears. The Wolves sceing this believe that they have killed him, and go out in their eanoes again. As soon as they are on the water, Mink comes out of his hole and shouts out, "Hullo, yon people, what are you doing ont there?" The Wolves hurry back, and Mink hides in his hole a second time. Again they thrust their spears in, and again he puts the entrails upon them and deceives them. After awhile, the Wolves go away believing Mink to be dead. When they had gone but a few steps, Mink ealls them back with a jeer saying, "Why don't you come and take me?" Time and again he thus deceives the Wolves, who, nt last despairing of capturing him, go away for good and leave him.

\section{LINGUISTIC.}

As far as I am aware, no attempt has been made to set forth the structure and grammar of the Síciatl dialect, or collect a glossary of its terms. The following notes and texts will therefore be the more welcome.

The Síciatl differs considerably from the speech of the contignous Salish tribes; and by the Indians themselves it is considered a difficult dialect to acquire. They tell me that most Síciatl ean converse in the neighbouring Slaiamon, Sk:qómie and Halkömélem, but that few, if any, members of these tribes ever aequirc a speaking knowledge of Síciatl. One reason of this is that its vocables are mostly foreign to those dialects. In the compilation of these notes, another illustration was afforded of the need there is to employ more than one individual in our studies of the native spech. The differences in the enunciation of the same words by Jack Isidore and Charlie Roberts were often so considerable, that I had on several oecasions to call upon a third person to determine the form to 
adopt and record. The personal differences in the speakers of barbarous and unlettered languages wonld appear to be considerably greater than those displayed by the speakers of eultivated tongues. This, in the case of the speech of the tribes under consideration, is due mainly to the undeveloped state of their phonology and the consequent indeterminate quality of many of their sounds, the result of which is a strong tendency to permutation in vowels as well as in consonants. This tendeney is very strong in Síciatl where $n$ and $d ; m$ and $b ; \vec{c}, \bar{i}$, ai, are everywhere interchangeable in the mouth of the same person and in the same words; and it is utterly futile to attempt to get the natives to distinguish between them, particularly the consonants. To them $\mathrm{n}$ and $\mathrm{d}$ are absolutely alike in sound even when uttered by a European. The same may be said of $m$ and $b, d$ and $t$, and all other distinctions of surd and sonant. This eonfusion of $n$ with $d, m$ with $b$, was at first a cause of much trouble to me; for sometimes I secured the one sound and sometimes the other in the same word in different commections; but on account of the difference failed to recognize it as the same; the sound for example of tcédis-tcédō, my dog, not suggesting readily to the ear the more correct form tcén's-tcéno. Many of the differences in the vocabulary will be found to arise from this permutation, and possibly some of the difliculty which the other tribes find in aequiring this dialect is due to the same cause.

My ehief helpers in my linguistic studies were Charlie Roberts and Jack Isidore. Others of the tribe gave me occasional help and assisted me in the determination of doubtful constructions and sounds.

An examination of my grammatical notes will show that the Siciatl differs in many interesting features from the dialects I have previously examined. Thus far, all examined have shown the employment of a different root for marking the future in verbs. The Siciatl is no exeeption to this. The radix employed by them is totally unlike that in any other dialeet. Considerable difference is also seen in their pronominal forms; and the temporal affix ne or le of the Halkōmēlem dialects is changed to tê in Síciatl.

\section{Phonology.}

Vowels.

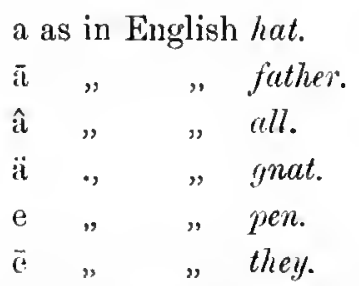

$i$ as in Euglish pin.

i " " pique.

o " " pond.

$\overline{0}, \quad$ "tont.

n " , but.

$\overline{\mathbf{u}}, \quad$ boot.

E obscure vowel as in English flower; ", a terminal vowel ouly in part articulaterl.

\section{Diphthongs.}

ai, as in aisle; an, as in eow; oi, as in boil; ell, as in few.

I have called attention in former reports to the indeterminate character of the vowel in the Salish dialects of this region. This quality claracterizes the 
Síciatl vowels in a marked degree, particularly the long vowels. There are also many obseure vowel sounds in Síciatl as in the other Salish dialeets; but I have refrained from multiplying the symbols for these on aeeount of the "personal equation " in the speeel of the natives; no two as a rule, as far as my ear could detect, using quite the same sound in the same phrases. And for this reason I loold that any attempt at over-refinement of sounds in setting forth the phonology of native speech defeats the end in view; the more particularly when the sounds have been gathered as is frequently the ease, from one person only. For all praetical purposes the symbol $\mathrm{E}$ as here used serves the purpose of indicating the obscure eharacter of the vowel very well.

\section{Consonants.}

b, as in English. This sound is never used in Síciatl as the complement of $p$, but is a permutation of $m$.

d, as in English. This sound is always a permutation of $n$ in Síeiatl and is never the sonant of $t$.

$h$, as in linglish.

$\mathrm{k}, \quad, \quad$,

$\mathrm{k}$, a strongly palatized $\mathrm{k}$.

l, as in English.

tl, an explosive palatized 1 .

$\mathrm{L}$, the same but shorter.

III, as in English, everywhere interchangeable with $b$.

$p$, intermediate between our $p$ and $b$.

$\mathrm{s}$, as in English.

$\mathrm{t}, \quad, \quad$ generally ; oceasionally intermediate between our $l$ and $t$.

w, , "

y, ",

$q$, as $c h$ in loch in broad Seotcl.

Q, approximatcly as $w h$ is uttered in North Britain.

1f, as the German $c h$ in $i c h$.

c, as in English sh.

乌, as $t h$ in the word thin.

te, as $c h$ in the word church.

is, as in the worll fits.

kw, as qu in the worl quantity.

In the mouths of some of the Síciatl initial $s$, runs uniformly into c. S, $\mathrm{S}$ and tl, particularly when finals, are also interchangeable in the speech of some natives.

'marks a panse or hiatus, as : k'lEmím, to 'chop."

"written over a consonant indicates that it is uttered explosively with stress, as: t'pitios, "blinll." 


\section{Accent.}

Accentuation in the Salish tongue is as marked as in English. But it has a wider syntactic and grammatic use than in our language. I have not yet satisfactorily determined in my own mind the basic principle of the accent in Salish. The fact that the position of the accent in the same word frequently varies in the different dialeets tends to make the subject more difficult. But speaking broadly two main prineiples reveal themselves, viz., radix aceentuation and quantity accentuation. Both these rules are frequently disregarded and the accent is shifted to some other syllable in the word for syntactic and rhetorie purposes.

It is a common prineiple in the Salish dialects to distinguish homonymous terms by a shifting of the accent, more particularly when the words have an etymological identity. Thus : sk ómai, hair, and sk'ontaí, dog ${ }^{1}$; metcín, liec; and mÉtein, testicles.

\section{Nimber.}

Number is distinguished in Síciatl in a variety of ways, as in the other Salish dialects. There appears to be no true plural, the same form being used for the singular as well as for the plural; but wherever the idea of severalty or distribution enters the distinction is effected by a modification of the stem. This is done by reduplication, by epenthesis, diæresis, aphæresis, epithesis and by vocalic mutation. Ideas of greatness, abundance or plentitude are expressed by means of separate particles. The following words offer examples of these methods, thus :-

Swấwelōs, boy.
stônie, man.
qaíEls, stone.
sīyákōp, hat.
stekaíū, horse.
hópīt, deer.
tcítwon, bear.
tlúmstan, house.
síya, log.
k·lấkátl, old.
qāmếmanes, old.
stōtélemit, old.
swà̄étwelōs, boys. stémtōmic, men. qEqaísls, stones. sísíyákōp, hats. stektéakain̄, horses. hephốpit, dcer. teitcitwon, beurs. tlâtlumstan, houses. síyam, logs. (This is a very unusual form.) k'läkäwatl, old (several). Qūmenémanes, old (several). stätōtelEmit, old (several).

\section{Gender.}

Gender is distinguished in Síciatl by the use of demonstrative particles, which alone possess a formal gender; by the use of separate words, or by placing the terms for "man" and "woman" before or" after the class word, thus :-
te, masculine.
tle, or $\mathrm{sE}$, feminine.
man, father.
tan, mother.
stómic, man.
tlấnai, woman.
swấwelōs, boy.
tlītlánai, givl.

- These dogs were reared for the sake of their hair, hence the term. 
In Síciatl there appears to be no modification of the terms for "man" and "wonn" when applied to mark gender in animals as in the Halkômélem and skiqgómie dialects, thus: stónie-tcédō, dog; tlánai-teédō, biteh.

\section{Case.}

In the Salish tongue ease distinctions are wholly wanting. The relations expressed by case-endings are in this language supplied by particles; the Salish being an analytical tongue like the English, with which it has many other points in common.

\section{Reduplication.}

Rerluplication plays an important role in Salish and has deeply affecter the development of its grammatical and lexical forms. It subserves a variety of purposes. Primarily its function is to express severalty or distribution. It seems also at times to denote the idea of plurality; but on this point I am not yet certain, for in many instanees where it seems at first sight to mark the plural, a closer examination shows that the predominant idea is really severalty. The ideas of augmentation and its opposite, diminution, are also expressed by reduplication. It also expresses intensity, repetition, frequeney and prolongation of verbal action, collectively, totality, superiority and its opposite, inferiority, and several other categories. The expression of these several ideas is effected by phonetic ehanges in the radix or by a shifting of the aceent. In words of one syllable the whole word is usually duplicated. In words of more than one syllable the radieal syllable only is duplicated. This appears to be the general rule, but exceptions are not infrequent.

\section{Diminutives.}

Examples of diminutive reduplication in Síciatl are as follows :-

\begin{tabular}{|c|c|}
\hline tlúmstan, house. & tlètluunstan, little house. \\
\hline stōō, river. & stótElō, rivulet. \\
\hline qaikls, stone. & qaiqaiels, pebble. \\
\hline tcédö, $\log$. & cétcēdō, puppy. \\
\hline hópint, deer. & hōhōpit, favn. \\
\hline kwödöt, porpoise. & kwōkwōdōtōtl, young porpoise. \\
\hline kwinis, whale. & kwè(a)kwinis'ōtl, young whale. \\
\hline
\end{tabular}

N.B.-The sufinx -otl seen in the last two is added to distinguish the words from homonymous forms in the language:

$$
\text { kwätlt, dish; kwákwetlt, platter. }
$$

Other examples of reduplication will be found in the vocabularies and native texts given below.

\section{Augmentatives.}

Angmentatives in Síciatl are commonly formed by prefixing the particle ti or tê to the term, thus : tê-thímstan, a large house; tí-yōilóçōt, a great hunter; tî-stólō, a large river. 


\section{Substantivum Instrumentale.}

The instrumental suffix -tEn so characteristic of the Salish dialects finds a place equally in Síciatl, thus:-

\begin{tabular}{|c|c|}
\hline$w$. & ${ }^{1 k u p a i a k w o ̄ i ̀ a-t E n, ~ f l n g e r-n a i l . ~}$ \\
\hline -tEn, a wall. & tEn, a stocking. \\
\hline sail. & sēlósE-tEn, food-mat or tablecloth \\
\hline wắl-tEn, speeeh, language. & tlatc-tEn, lnife. \\
\hline Ek'Esōt-tEn, ladder, steps. & kwál-tEn, $a$ hidin \\
\hline ÉQulHē-tEn, $a b r u s h$. & kwēkwīnōs-ten, a mirror. \\
\hline
\end{tabular}

It is interesting to note that no two dialects apply this suffix to the same category of terms. It is one of the most interesting of the Salish formative elements.

\section{Substantiva officialia.}

These arc formed in several ways, chiefly by the prefix mūks-, secondly by reduplication of the stem, and occasionally by the prefix of abstraction, s, thus :-

nuiks-âtcetc, a stutterer; from âtcetc, to stutter.

nūks-stélim, or steltếlim or steltel, from têlēm, to sing.

minks-êtōt, or setétōt, a sleeper; from étōt, to sleep.

sútētōt, a dreamer ; from utếtōt, to dream.

nūks-yōìlóçōt, or yōyōilóçōt, a hunter; from yōilốçōt, to hunt.

stciltcilótl, a robber; from tcilótl, to rob.

kwōkwōyíluk, a mueder of one person; from kwóyiluk, to murder or bill.

kwōwaiyiluk, or kwōkwaímaç, many times a murderer, from same root.

sóōmat, a lazy person; from óōmat, lazy.

nūks-kwêkwētlkEn, an interpreter ; from the reduplicated root kwêkwêtlkEn.

s'tcấtcaleten, a fisher ; from s'tcálēten, to fish.

\section{Synthetic Nouns.}

The Síciatl usually employ synthetie or incorporative nouns when speaking of the body or its parts, and in a few other constructions such as class numerals, tree and house conpounds, etc., thus :-

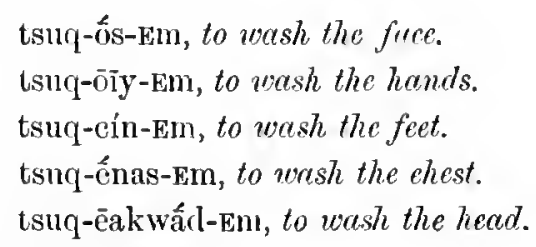

I This formation is different from that of any of the other dialects previously examined. It signifies "thing for seratching or digging." 
êtlā-wałada, I hurt my ear.

étlī-wóiya, I hurt my hand.

te-tcin-sḱpai-ynk; I strnck my nose.

tē-tcin-suk-ālâlīō", I hurt my head (from something falling upon it).

snk Emáliōk, I hurt my head (by passing through a low doorway, etc.).

lsinliok-tcin, $I$ hit my head (by striking the floor with it in lying down).

The incorporative forms for house are, -ante or -tQ, for tree -ai, thus: naite-antQ, one house; samítQ, tuco houses, etc.; kwósEn-autQ, star-house ; spal-ai, one tree: tÉmcid-ai, two trees, etc.; cedar-tree, túqEm-ai; fir-tree, pelád-ai ; naple-trce, k’úmol-ai, ete.

For numeral compound forms see under Class Numerals below (p. 69).

All these synthetic forms may be rendered by the independent forms and frequently are. Speaking generally these forms are derived from the older elements of the langruage, and are found with slight modification in all the Salish dialects.

\section{Compound Nouns.}

The compound nouns in Síciatl are formed as in the other Salish dialects examined, by simple juxtaposition, by agglutination, and by formative elements. Abstract nouns are formed directly from the verb sten by prefixing $\mathrm{s}$ to them, thus : êtlten, to eat; sêtlten, food; kait, to shout; skait, a shout; kwut, to see; skwut, sight; utêtōt, to dream; sutêtōt, a dream; téūcam, or têtéūcam, to learn; stéúcam, or stêtéũeam, learning, instruction.

\section{Personal Pronouns.}

Of these there are in Síciatl three elasses, the independent, the copulative and the incorporative. The independent pronouns are :-

$I$, me, sắlīyū.

thou, nūwill.

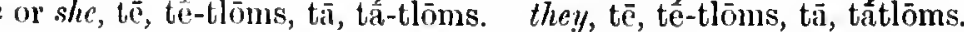

The forms for the third person are really demonstratives, and are usually employed without distinction of sex, the context marking this. In constructions where it is neecssary to distinctly mark the sex sẽ or tle is used for the feminine.

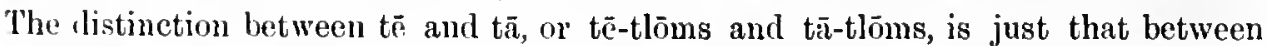
hic and ille of the Iatin. A elear idea of the function of these demonstrative forms maty best be gathered from a study of the native texts given helow. In the plural the compound forms are sometines reduplicated, thus : tátetlōns, they.

A selective significance is given to the pronouns by placing the demonstrative particles $t E$ or tle before them, according to the gender, thus :-
tE sălìy $\bar{u}, I$.
tE tluémōtl, we.
tE nīwill, thou.
tE nüklap, you. 


\section{Copulative Pronouns.}

$$
\begin{array}{ll}
\text { I, -tcin, tcin-, -tcan, tcan-, -an. } & \text { We, -c't, -tcat, -at. } \\
\text { thon, -teñ, tcūq-, -tcanq, -auq. } & \text { You, -tcílep, -ap, -f́lap. } \\
\text { he, she, -rs, -s, -tas. } & \text { They, -as, -aswêt, -tas, -ёt. }
\end{array}
$$

The function of these will best be sem in the native texts given above. It will be seen that they are sometines prefixed and sometimes suffixerl.

\section{Incorporative Promons.}

These forms present considerable differences from the corresponling ones in the dialeets previously examined.

qatl-nōmi-tein, 1 like thee.

ratl-nōmi-c't, we like thee.

qatl-uōm-tc-tcūq (tE sâlīyin), thom likesl

me.

yatl-nīqu-ña-teñ, thou likest him, hro.

qatl-ntict' (tE), you like him.

(qatl-nōmōtl-as, he likes "'s.

' aatl-nomōtl-asèt, they like us.

qatl-nomim-elap, he lities you. qatl-nömimelap (aiyawèt), they like you. ratl-nōmi-tcil-slap, I like you. qatl-nōmi-e't-Elap, we like you. qaatl-nomōtl-tcūq (tF thēmōtl), thou likest 18.

qatl-tlau-nuiq-nia-teñq, thon likest them.

qatl-nounte-as, he lites me.

qatl-nontc-asēt, they like me.

qatl-nomim, he likes thee.

qatl-nòmim (aiyawêt), they like thee.

There is a ecrtain interesting miformity about these lorms which is wanting in the other dialects examined; throughout they have the reflexive pronominal stem nómöt, self, in common. 'The forms for the third person are also interesting. The particle nuig seen in them is not a pronominal element proper. It is the same determinative particle which plays so important a part in skecoómic constructions to which I have previously ealled attention.

From the following there wonld appear to be another method of pronominal ineorporation: but this is an irregular form.

kwenēçétein, $I$ ser you.

kwenéçétein flap, $I$ se' you (plural).

kwenētcin t'i $\bar{c}$, Isr him.

kwenèsásēt, thę? sac me.

kwenésin te nūwíl, thry sou thee.

\section{kwedém nr kweném $=$ to see.}

kwenésim te nūwilap, thoy saw yon (plural).

\section{Possession or Adjortiral Pronouns.}

Of these the Síciatl employ several distinct forms; they also make distinction hetween the thing present and the thing absent, the commonest form is as follows :- kwenéçtcūq, you see wr.

kwenéçetcälap, „jou sec me (plural).

liwêkwenêtcin, I see them.

kwenëtônoçss, he saw me.

kweneccus, he ser" thep.

t.




\section{Singular.}

t.ti-n' man (object present), m.! folle'r.

tek-na man (object absent), my father.

tE man (object present), thy fatter.

tce man (object absent), thy father.

tE man-s (object present), his, her, father.

tce man-s (object absent), his, her, father.
Pliral.

tE-ms' man (object present), our father.

tee-ms' man (object absent), our father.

tE man-Elap (object present), your father.

tcE man-Elap (ohject absent), your father.

tE man-èt (object present), their father.

tcE man-ēt (object absent), their father.

The above are used exchisively with masculine ohjects. With feminine objects the following are employed :-

\section{Singular:}

ts'E-n' tan (olject present), my mother.

tle-n' (object absent), my mother.

$\operatorname{tg}^{\mathrm{C}} \mathrm{E} \tan ($ object present), thy mothei.

klE tan (object absent), thy mother.

ts's. tan-s (object presenu), his, her', mother.

tle tan-s (object absent), his, hor, mother.
Plurel.

ts'E-ms' tau (object present), our mother.

tle-ms' tan (object absent), our mother.

$\mathrm{ts}^{6} \mathrm{E}$ tan-Elap (object present), your mother.

kle tan-Elap (object alsent), your mother.

$1 \mathrm{~s}^{\mathrm{F}} \mathrm{F}$ tam-it (ohject present), their mother.

tle tan-ēt (object absent), their mother.

A simpler and more intimate form is as follows:-

Singular.

nE-tán, my mother.

n-tin, thy mother.

tan-s, his, her mother.

\section{Plural.}

nusnána-tan, our mother. n-tán-Elap, your mother. tán-ēt, their mother.

'This form is employel when the object is close to the possessor of it. Examples of its use will be found in the native texts below. As the demonstrative elements are wanting to it there is of course no distinction of grender with this form. It is the form most eommonly used in answer to the qnestion "Whose is this?"

The emphatic forms equiralent to the nE-swá or thuswii forms of the Halkimèlkm are as follows:- 


\section{Sinufular:}

tEn'sénī stcédō (object present), m!! own doy.

tcen'sÉnā stcédō (object absent), m!y own dog.

tEs'nã stcédō (object present), thy oun dlog.

tcesena stcédo (object absent), thy oum dog.

tEs'na stcédós (object present), his, her oun eloy.

tceÉna stcédōs (object absent), his, his own dog.
Pluzul.

twu'snínai stcéró (olyject present), our ourn dey.

tommána stcédi (olject absent), our oun doy.

tes'núnälap steédo (ohject present), your own doy.

teFsnánālậ stcédō (object absent), your own dog.

(Esnánèt stcédō (object present), their own doy.

tcesnánēt stcédo (object absent), their oun dog.

This word stcédo may also be written stcéno, the il being a permutation of $n$. I have, however, invariably employed the d because this sound so strongly predominates.

The particle kwa which plays so important a part in the Halkōmãlem dialects is also seen in Siciatl. It fills a subordinate place, however, in this tongue. It is found in pronominal forms and marks absence as in Halkōmélen, but is not used in quite the same way. I have not found any distinction between present and visible, and present but invisible, pronominal forms in the Síciatl, as in the Halkōmélem. In the expression, is your father dead ? kwa must always be used, thus: kwa kwố ter man? Its function here is the same as in the other dialects. It marks the absence of the object, or rather, as the tor form does this, the absence of knowledge of the lorral' of the olject spoken of. In Síciatl the particle kwō is used in a temporal sense in a manner peculiar to that dialect, thus we say : kwo kukelisélem, he is sifk, if the person referred to is in some other place. It is employed also in the following constructions: kwō-tcin kwātán tle siäcin a $\mathrm{t}$ tátkwat the stôlō, I left the paek on the bank of the rirer" kmm kwo auke te sêtlens, then "ruray" or "elisappecred" all the frod. Tè kwo kntL te ma, "Father is cominy." It is found also as a compound of tlöm, thus: kwō-tlom in contradistinction to tê-tlōm.

\section{Substantine Possessire Pronouns.}

Sinupuluer.

nessua, wine.

usena, thine.

s'nas, sEnas, his, hers.
Plural.

uIESEnāna, our's.

us'nān Elap, yours

s'naneit, theirs

Possessive with Verbum Substantixum.

Singular.

netl-tcin-sEna, it on this or that is mine.

nētl-tes-s'na , , ., thine.

nët-ter-s'ms ." " " his, hers. 
nettl-teEm-s'nana it or this or that is ours.

nëtl-tcE-s'nāmelap " " " yours.

nëtl-teE-s'nānēt ", " " theirs.

It is interesting to observe the reduplication of na to mark the plural in these and the otler forms. There is no listinction hetween "inclusive" and "exelusive" forms in Síciatl.

A prepositional form is also used of the third person when the owner's name is mentioned. It is iclentieal with that in the HalkömélFm : thus: s'na tla John stedito, this is John's doq.

Possession is also thus expressed in Síciatl: "I have a horse," stếkaiñ teinsḱna : "you hare a hor'se," stékaiñ tewśna: "he hos " horse," stếkniñ te Esfrnas, ete.

\title{
Interrogative Pronouns.
}

wat? who? wat-teñq ? who are you? wat ei-tī nEnt tī? who male this?

tn-wat? whose? wat? whose? nettl wat ti ? whose is that?

stam? what? stam te-tlom? whet is this? stam tes sqatIs? what do you want? stam íya tee sqatLs? what does he want?

kwíntea? where? kwintea tew stêkaiñ ? where is your horse?

nftea? whieh? nfitea tee tlumstan? which is yom house?

\author{
Reflexive Pronouns.$$
\text { nómōt, sclf. }
$$$$
\text { tê-tein-sEpe-nónōt, } I \text { struek myself. }
$$

This form is identical with that in the Skqómic. In Síciatl it is an essential eonstitnent of passive verh forms and incorporative personal pronouns.

\section{Tudefinite Pronouns.}

au-wat, anybody, watásye, somebody.

\section{Demonstrutives.}

tE, tè, têtlōu, taitlōm, he, this, that: tle, sè, sétlōm, tlátlōm, she, this, that.

The above are used principally with the third person, but not exelusively so. When the objeet is other than a person the following forms are usually employed :-

$\mathrm{ti}$, this; thi, that (objeet little distance only from speaker).

i tin, that (object farther off).

$\bar{a}$ tā teūk, that (object very distant).

There are no distinet forms to mark the plural. When it is desired to nse them in this sense the objeet suffer's modifieation, thus: ti tlatumstan, these houses; tin thathumstan, those houses. 
Articles.

tE (masculine), tle (feminine), the, a; kwa, a.

The function of these can be gathered only from a study of the native texts. Consult also the writer's renarks on this head in the 4 th Report Ethnological Surrey of Canceda, 1902, B.A.A.S.

\section{Numerals.}

Síciatl abounds in class numerals. The simple absolute forms are as follows :-
1. pấlı̀.
5. çúlateis.

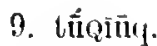
2. tenuicín.
6. t'Équni.
10. op ô1.
$\therefore$ teîtlas.
7. tsótcis.
11. ốlen íta păla.
4. mōs.
8. tEätcis.
12. ốpEn íta tEmiến.

The otlers follow in like numner:-
20. sámpea.
50. cílatca.
90. túwīeqaued.
21. sámpea íta pấla.
60. t'ÉqEuatsei.
100. tEsáwite.
30. tcădauca.
70. sótcisaca.
1000. ópen teș̈́witc.
40. mósatlea.
80. tEä́tcisacit.

\section{Partitive Numerels. suk;, hulf.}

There are in Síciatl 10 terms corresponding to "quarter" or "three-quarters," as in the Halkōmếlen.

\section{Class Numerals.}

1 nu $u$, nitcálii (stớmic).

¿’ mon, temicnấlī (stḱnıtōunic).

3 " tcaçúlí.

4 " mōsálī.

5 " sēlatsáli.

6 " tuqabálī or teqamálí.

7, sōtcisálí.

8 , t'Éltcisälī.

9 " tūoùcẩlì.

$10, \quad$ openấlī or ōpediílí.

11 „ ọpenälī íta nītcáaì.

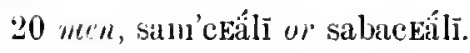

21 „ sam'ceálí íta nitcálī.

30 "cadaucấlī or tcananuáli

40 " mōsElcấli.

50 , sēlatscíilī.

60 , tuqabatscálī or teqam'tscếlī.

70 "sōtcisacâlī.

80 " t'Eatcisacálī.

90 " tĩęiqacílì.

$100, \quad$ tesawitcáli.

1000 , ópen tesawiteálī. 


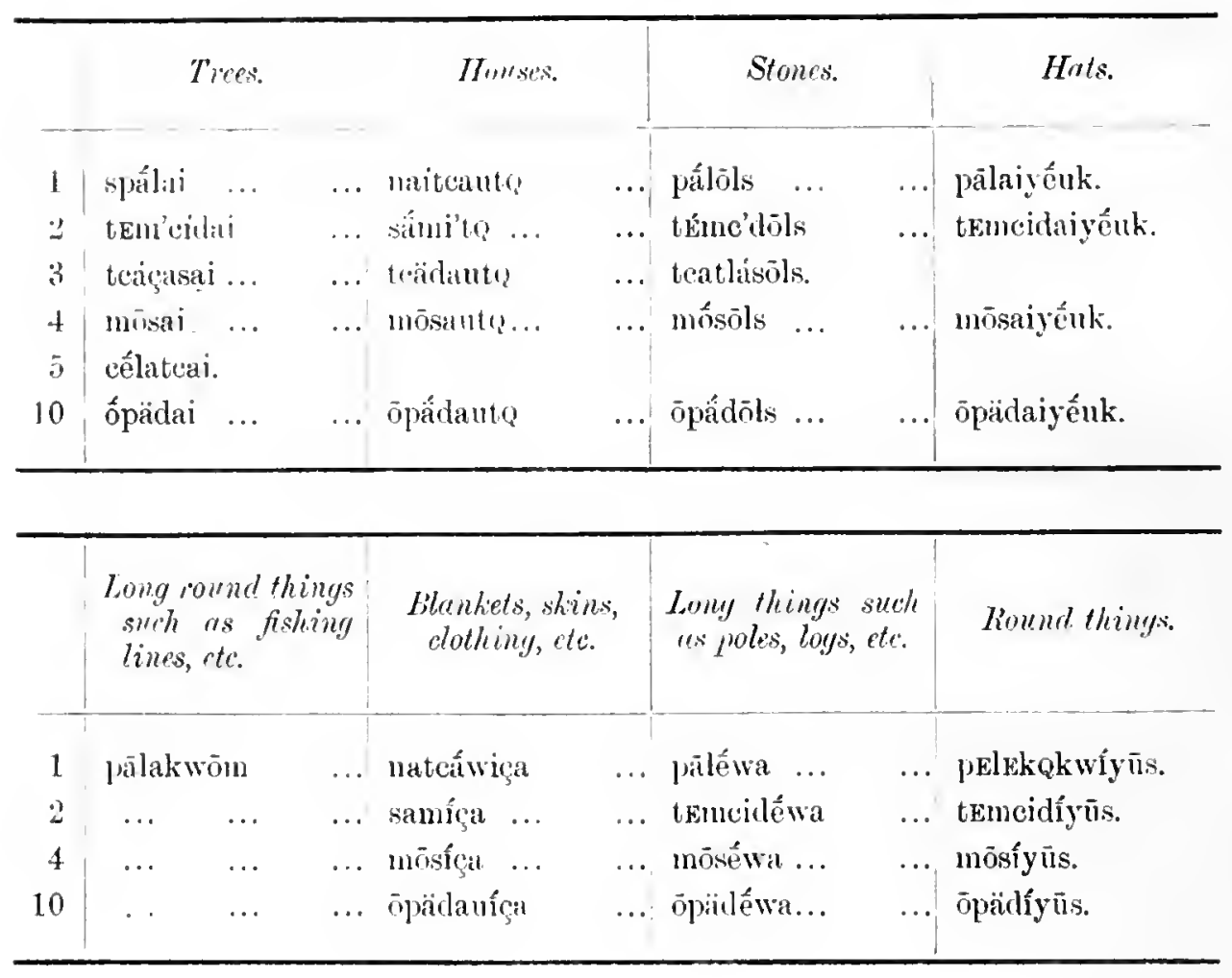

\section{Ordinals.}

first, tlasếu, seromel, stetsít, or stesêt = " neut," "close to," thirl, stetsít tlal = "nent ugain." All after the second are cxpressed as the third, until the last which is rakwaitabot, wr arkwaitamōt.

Adrerbial Aumerals.

once, naiteatuy.

twiè, sắna or sába.

thrice, teánauq.

four times, mósatl.

nier " silảtsall. six times, tEq Ematl.

seven " tsótcēsatl.

eight. " teấtcisatl.

wine " túqiaqatl.

ten " ópunatl.

Distributices.

páptilat, one rarth.

tétkmiciu, tro" ,

tcitcatlas, three "

mónis, four "

tsêttslātcis, five ,"
t'éELEYuI, sis: euch.

sóöteis, severn "

tètätcis, eight "

tētQíñ, nine "

óopan, ten ,

têtsawite, one hundred cach. 
Comparison of Adjectives.

Positive.

êĩ, good.
Suprotutive.

trōgait ết, brist.

Strietly speaking there ale but two degrees of comparison of the adjeetive in Síeiatl as given above, but a kind of emparative is formed by using the superlative form with little stress. In other worls the degree of excellenee or its opposite is expressed rather by the voice than by the term. 'The longer the expression is drawn out the more superlative it beeomes.

\section{Verls.}

The intlection of the rerb in Sielatl is effected as in the other Salish dialects examined by means of affixes and auxiliary verbs. The aorist or indefinite past is formed by prefixing the particle te. This corresponds to the $\bar{c}$ of the Sliquomic and Halkōmélem clialects. The regular jakt is formed by affixing to the verb stem the partiele ōtl; the ètl of the other dialects. The future is expressed by the aldition of the particle skwa. These are the prineipal tense signs in Síciatl.

\section{Intrensitive Ferb.}

\section{Present Tense.}

Singular.

Pluial.

kukElăsélEm-tcin, $I$ am sick.

kukeläsêlEm-e't, we are sich.

kukElāsélem-teñq, thou art sick.

kukelāsếl tum-teillap, you ure sick.

kukElāsélEu, he, she, is sich:

kukElāsélem, they are sick.

Aorist or Indetinite 'T'ense.

tē-tein-kukelasēlEm.

tē-e't-kukelāsēlEıı.

tē-teūq-

tê-tealap- "

The English equivalent of this form is diftieult to render. It can only be given by a cireumlocution suel as, I was and still am siek, ete.

Past Tense.

Singular.

Pirival.

kukelăsélentu-ōtl-tein, I hure been sich: " "-ten̄y, thou hast been sick.

kukeläsếltin-ōtl-c't, we hare bcen sich. " -n-teilap, you have been sick.

F'uture l'ense.

kukElāsếlem-tcin skwa, I shall be siek.

" -teūq skwa, thou wilt be sick.

" skwa, he will be sich.
kukElāsēlEu-e't skwa, we shall be sick

" -tcilap skwa, you will be sick.

"tcalap skwid, they will be sick. 
Conditionel Forms.

wE-kukElissélem-En, when or if I am sich.

-auq, when or if thou art sick.

-at, whon or if we are sick.

-ap, when or if you are sick.

Dubitatice Form.s.

aiquiqốmEla we-kelāsélen-En, I may or perhups I may be siek.

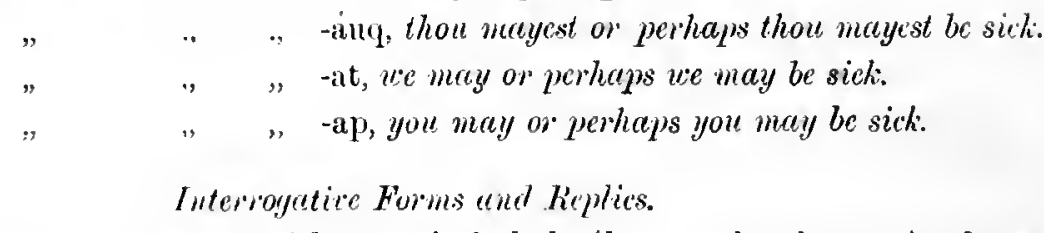

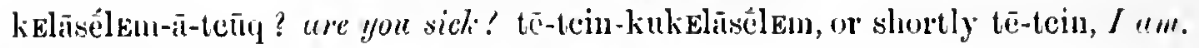

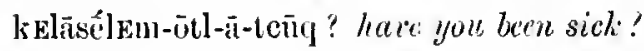

kukelïsếlEm-ōtl-tcan, or shortly ōtl-tcan, or tcau-ōtl.

Negative Forms.

uâ-tcan kuth kukelisếlem-an, I an not sick.

wii-teal ", , -at, we are not sich.

uqu nesquitlas kwens kelīsélem, I don't want to be sick.

Periphrestic Forms.

ģotiwwón-tcin kwkns kelāsélem, I think $I$ am goiny to be sick

súliwèwon-tcin WE-kEhīsếlEm-an, $I$ am afrail I shall be sich.

\section{'Trustitice Verbs, Actice Voice. \\ sfipetut, to strike. \\ Present T'orse.}

Singulur.

stept-tcan, $I$ stritic.

$"$-tcanq, thou strikest.

" -as, he, she, strikes.

\section{Plurel.}

sEjet-tcat, we stritic.

" - tcap, you strike.

" -asēt, they strilic.

Pirsent Pevfict Responsive Teuse.

te-tcin sÉpkt-äl, I tur strilizing. téec't sEpet-at, ưc are striking.

'The other persons follow regularly in like manner.

'This tense is used in reply to question, "What are you doing?" and it is interesting to note that the anxiliary verb attracts the primary pronoun, while the verl, takes the secundary. The same is seen in the following forms :-

Present Continuous T'ensc.

tē-tcin ŝ́p'-nūQ-En, I am striking it.

tè-tcīq sêp'-nūe-auq, thou art striking it.

nētl-të sÉpE-nūQ, he is striling it. 
tē-e't sÉpE-nūç-at, we are striking it.

tē-tcap sÉpE-nuQ-ap, you are striking it.

nētl tē sÉpE-nīg, they are striking $i t$.

Another form of this tense is : pîliei-tein sḱs'pE-nūe, etc., etc.

Past Continuous Tense.

sÉs'pe-nūe-tcin, $I$ reas striticing it.

" -tcīq, thou wrest striting it.

" "he was striking it.

"-c't, we were striking it.

" - ap, you uere striking it.

Pest Perfect Contimeous Tense of licmoter Action.

sE'pe-nuerótl-tein, I leece or had becn striking it.

" $\quad$-c't, ere " "

'The other tenses follow regularly in like uamner.

l'cst I'erfact Cuntinuous Tense' of hecent Action.

sEs'pet-ötl-tean, I have been striling it.

"-tcat, we

The other tenses follow regularly in like manner.

Pest I'ense.

sÉpEt-ōtl-tcan, I struck, or I laee struck.

sÉpet-ötl-teat, we struck, or we have struck.

The other persons follow regularly in like mannes.

Future Tense.

skipt-teiul skwi, $I$ shall strike.

" -tcat skwa, we shall strike.

'The other persons follow regularly in like manner.

My collections of native texts have not furnished me with any other form of the future than the above. There is no instance, I think, of this tense being formed by the verb "to go" as in other of the Salish dialects.

\section{Impremetive Mood.}

The imperative inflection in síciatl is -la or -Ela, thus :-

sElitela! strike!

sEp't-teauy skwa! strilie you!

'The use of the luture particle is interesting here.

sEp't-dn qēlat, $I$ will strike, or $I$ am determined to strike.

Other lorus of the imperative are: sEp't ! strikic! this form is employed when speaking to one person alone. When the command is given to several persons the following forms are used: sépetī! sEpetíla! strilie! 


\author{
Obligative Forms. \\ tế-tcin-sEpE-núQ-En, I must stritie it.
}

Negative Form:

Present Tense.

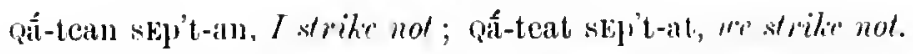

The other persons follow regularly in like nammer.

l'ast Teuse.

Q'ôtl-tcun sEp't-an, I diel not strike; Q'ótl-teat sEp't-at, we diel not strilic.

The other persons follow regularly in like manner.

Future Tensi.

Qú-tcan-skwa sEp't-an, I shall not strike; Qâ-tcat-skwa sEjit-ilt, wo shecll not strike.

Imperative.

Qí-tcauq séspet-auq! don't strilic it!

quátcauq sépEnōme-auq, don't strilis me.

Q'a-tcat ketl sépet-at, don't let us strilie it.

qấ-la skispeçau, don't strikic me.

Q̄ĭ-tauq sÉpE-nūQ-auq, don't you stritic it.

In these negative forms it is interesting to note that the negative attracts the principal pronom, the verl) taking the secondiny forn In the fourth sentence the negative takes the imperative inflection, la.

\title{
Miscellaneous Forms.
}

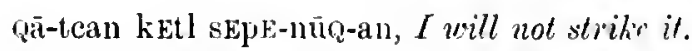

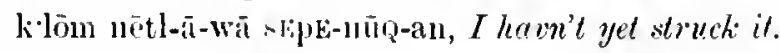

\section{Conditional Forms.}

sÉs'pet'-tean, if I strikt.

sk'pet-teat, if we strike.

The other persons follow in like manner.

kwEns tē-wE-tl sépet', when I strike or struck it.

kwōnus " sÉsEpet', when u'e " "

Uptetive Forms.

nEsqat], kwEHs sÉpet", I rish I could, or I should likt, to strike it. nusqath kwöms sésepet', we wish we conll, or uc should lilic it.

\section{Interrogative Forms and hieplics.}

1. se setas? did he strike? tō sepetas, he struck it. tā-tcūq-hă-sEpEt ? diel you strike it! tê-tcin, I diel. sFpet-it-c't? did we strike it? tei-c't, ue dirl.

l'he interrogative sign is $\bar{a}$ or hă, the same as in the Kwấntlen. 
Iterative Forms.

tē-tcin(E)wa-tl-sés'pet-an, I am repeatedly striking it. tē-c't-wa-tl-sḱs'pet-at, we cre repectedly striting it. pála sÉs'petas, ho is striting it wlt the time.

ses'pet-auq, krep on striking: ses'pet-teap, keep on striking (plu1"al).

Deprecetice Furm.

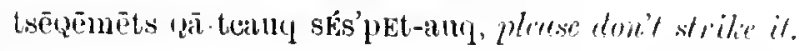

Reciprocel Formes.

sÉpetautl, we struck euch other.

sãjấtela! strilic one cuother!

Infinitives.

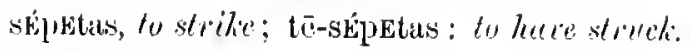

Perticiples.

sÉs'pkitals, striling: sEpet', struch.

Pressien luiee.

sEy', streck:

I'resent l'erfect of Accidental Action.

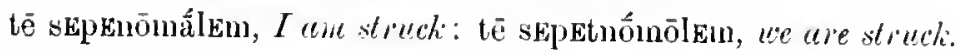

Present Perfect of Pmiposiec Action.

tê SEPEÇálEn, I tem strueh.

Past Prifoct of Accidental Action.

sep'uōmáltèm-ōtl, I have been struck.

tế-tcin-sEp', I have been struck, or I huce strueck myself.

Conditional Form.

k's tē sepeçâlem, If I ant struck't.

Kieflexive Foms.

tê-tcin sépenōmōt, I strike myself.

sEpenömöt-itt-tcin, I have struel: myself:

A secondary furm of the present jerfect is as fullows: te-tein-stublt, $I / \mathrm{m}$ strucli (with a stick); tẽ-c't-sEpelt, uce are struck (with a stick).

Miscellaneous T'uxts.

I struel you, têtcin skiknómí (in answer to question "did you strike me !").

it is going to rain, kwo-kntL tcitl (the particle kwo here marks the absence of the rain).

he struck me, Lē sÉpEnōmeas.

it is John's dog, snā tla John teédō or tcénō. 
wo have some hoist's, stéakaiñ tcimsnána.

nyy dog is white, kwEsêm tcen's tcédō.

come with me, mēla kumét mèes.

bring we the horsc, mestwela te stéakain.

yive we the horse, yiliskla à te stéakain.

it is cloudy, te samkwellelt.

"re you hungry? kwakwai-íleluy? I em hungry, kwakwai-tean.

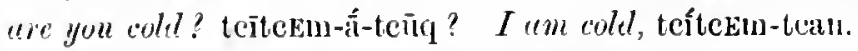

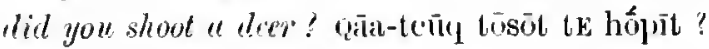

it is John, nêtl ì te John.

it is Mary, nètl à tle Mäli.

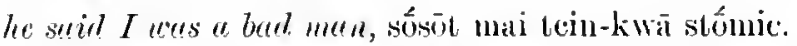

when you come in shet the door, wE-kwntlany mastü LEk Et tE cautl.

I ve!yht to drinti, kōkō-tcan skwa.

he stole my horse, kwötcelotl uteEu stéaliain.

he stole your horse, kwōtcelotl uteE stéakaiñ.

it is raining, tē-wetl-tcítcitl.

ij it rains I shull not go, wE teitctlas qui-tean skwa sō-all.

I live here, nī tean à tĩ (in answer to yuestion).

I live there, kwō tein nē à tĩ (in answer to question).

$I$ e"me s"súcietl, cīcatl-tcin, or sīcatl-tcin.

I um huntiny, yīyīīlorōt-tcin (in answer to question "what are you doing ?").

"canoe metie", hai-hai.

"basket maker, IIöHopailite (liom Hö]", "lo pierce").

"stone, qaikis.

is it a stone? qaiéls-ia!

is that the stome! (pointing at object) qaiėls tâ-tlōn?

this is the ston', yaikils té-tom.

which stone? kwintea tee qaiḱls!

is that a stone? quiéls-ît tâ-tlōm?

what kind of a stone? stam tkíq qaiḱls!

is that a black stone? k'wesém tĩ-tlöm qaisils !

once dog, luédō, stcédī, or teénō.

two dogs, tcéd-tcedō, stcéd-tcēelo (or -nō; $u$ and $l$ are intercliangeable).

no doys, Qüli't tcédō.

"lny elogs, te auko téélim.

many dogs, likq ucédant.

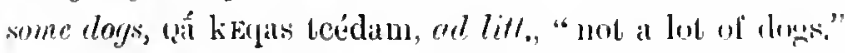

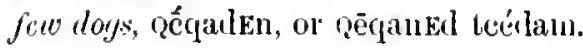

right eur, aíyūlbaiedí or aíyūhmaienái.

left ecer, sékwaikdá or sêkwaienái.

both cer's, kwólkwoladíi or -níi.

right cye, aiyúlbalōs or aiytílunalōs. 
left eye, sćkālōs.

both eyes, kElkElóm.

right hand, aiyúlbōìya or -mōịya.

left hand, sēkốya.

both hands, tciltcälic.

a. good dog, äi stcédo (or -nū).

my back is sore, qus ten életcin.

your bark is barl, mai te életcin (singnlan).

his bark is barl, mai élétcins.

our borl: is borl, mai tems thletcin.

your barl: is burl, mai èlettein-silap.

this, tī, this house, tĩ thimstan.

that, tī, that house, tĩ tlúmstan.

these houses, tĩ tlátlumstan, those houses, tī tlátlumstan.

I want a hor'se, nesquitlcis stéakaiñ.

$I$ am. thirsty, kōkamtein.

I want some uatr", nesquatleis éwur.

I vant some meat, nesqatlcis slëul:

$I$ burnt it, kwît-tcin kwásaten.

I burnt it all up, kwi-kerituq.

I bưnè my hand, kwāsawớyal-tcin.

I am burnt, tēe-tcin k’ítīq.

the moon will rise soon, te cálcịl súa ćna.

lie will come soon, gãoñǫas kum kwutI ểna.

I am hurt, ti-tcin érau.

that is your horse, is wna stéakain.

I must go soon, sōwatein sī.

ran you swim? gō̄tcūq qăkelémanq?

who mode this? wat-ci tì nefit?

$I$ made it, sâlīin or sâlȳì tī uEấi.

hre has billed my dog, tê kwóyūtas tern stcédō.

he killed it, te kwóyūtas (object near) te einteí (object far off).

one le erme to my house, naitcanq kwntL ii ten ulumstan.

I will come, kwntI-tean skwa.

often he eame to my hourses, palát kwokwut $\mathrm{L}$ a ten tlúmstan.

he is laughing, qaiqĩyam.

he is erying, qúqawōm.

who is that? wat tâtlōm.

it is Mary, nêtl se Máli. it is Joln, nètl tee Jolnn.

give me my hat, méstinq ten siấkōp.

malie "p the fire! tcímiakopla :

will you come with me? kwutL-í-tchiq kwa kumét te meç?

it is dark, klinkōn. it is cold, 'togaiteum. 
it is shomring, trwntl kwókwōnai.

is your futher detul! kwa kwót tex man?

is your mother deal? liwa kwōi kle tan?

are you cominy! kwutLatcūq liwăhá ?

he lives with me, skatlsêt tla sáliyī.

I scu the doy, kwo-tein kwedéten stcédō.

the moon is bright, te cílcäl steqait kailts.

this house is yood, te tlumstan ei.

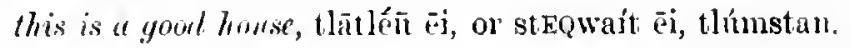

we tren, palai (siya).

tro tries, témicidal.

"s surell tree, çóçai.

a large tree, tíai.

many trees, keqai.

no trees, oāk't síya.

fru trees, qéqauku síya.

any tiee, auke síya.

all tres, auko síya.

\section{Prepositional Phrases.}

on the brach, it te tcau.

near the house, stesait $\bar{a}$ te thimstan.

in. lied, it te âçelite.

on a stome, i tre qaíels.

iit the bor, in te kwíkwa.

in the sk? it te tsik:

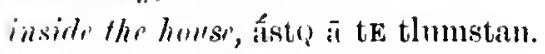

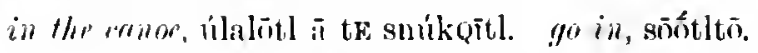

\section{VOCABULART.}

\section{Comporeal. Terms.}

hearl, sk·ńkmu.

face, métisteu.

"roun of the heal, silitleuk", kntlkwat.

side of the head, tiitaíyas.

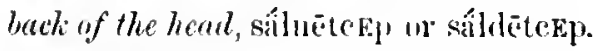
rorchead, élsku.

check, siilakwótla (or - mu).

jum, kwokaikk.

shill, sk wothos or (ois).

hair, mákēn.

beard, kwópogegin.

herir of the bodly, skwónpeus. hair of animals, míkīn.

tooth, y'inis.

tongue, têukças.

palate, kwátemkain.

yıms, tleakwóldis (or -nis). nose, múksku.

scptum of nose, skwếnk: ertr, kwoláda (or -na).

lobe of the cur', slipoiada (or -na).

eye, kf́löm.

syr-lashes, tlépten.

rycbrou*s, çīçốbra. 
pupil of the "ye, kulmiotil wos.

mouth, çóçin.

N.B.-Arcording to my informants there is no distinction between upper and lower lips, no terms existing in Síciatl for "lips." throat, tsălt]as.

neck, têwéda (or-na!.

breast, sélëdus (or -nus).

teut, skEm.

mille of the breast, skEm.

back, élētcin.

side, kwatámelōm.

loins, wōk télete (or -nete).

stomach, qaíym.

arm, tätúya.

shoulder, sälấqEn.

spine, naniwa.

luand, tcấlic.

finger, qúlēakwōốya.

finger-nail, kúpaiakwōíyaten.

thumb, kläkēakwōĩya = eldest finger.

1st finger, klakhōpōyyáli $=$ "the. pointer:"

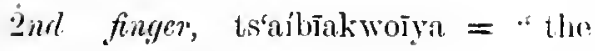
strongest."

ind finger, skaíklwīakwoíya = "next strongest:" little funger. skíteakwợy = "last onc."

elbow, kwomenlaqkn.

thigh, saldētốlkp.

leq, seautcin.

knee, kwómnq.

foot, y écin.

solf of foot, pekálein.

toes, skwaícēakwớcin.

toe-nail, kupaiakwóneten.

bone, ear.

skin, sQóbelete.

heart, s'lskwēdas (ol" -11as).

blood, skaitl.

lungs, sqúsep.

bowels, kaíaq.

belly, túk'wilas.

spinal-e(n)l, smaçíliak En, tem sqaúlıa.

brain, smaçäliak En.

liver, púkpuk.

sinew, tlées.

muscle, tintc.

rexu, pren, póqein.

fret, gus.

rib, lúaq, laúaq.

tril, sopparlete (or -noti).

Terins of the Principal Animals known to the Steiatl.

horse, stéakaiū.

¿log, stcédō (or -nō).

lear (black), stcítīon.

, (grisly), maiyku.

«eer, uốpit.

elk, kajēte.

wolf, wōkwedáte

beaver, skÉmetl.

mountain-yout, sqaítlai.

receoon, mélalīs.

lynx, mớliq.

wild-eut, wiiláksīa.

nountrin-lion, skúkwikkïm. otter, sk:íatl.

rabbit, sóspit.

veasel, pipkatltcaíac.

skunk, spälas.

bat, páçpáçebak:

chip-monk, qaiepêtcin.

squirrel, skwớìa.

crane, pákwaiyus.

hawh; kakakawénūǫ.

fish-hawk, tsētúqtséñ.

woodpecker, sláluk".

, tếtlate.

rat, skwiikớbin. 
mouse, kwáten.

flea, matcóst́la.

louse, mÉtcin.

yoose (blaeli), qia.

" ("hite), klíkiwamm.

ruele (mallarl), trinuks.

lum, skíkaièu.

ond, skaiakmik:

colyle, kraike.

jay (biur), skickar.

robin, skw'éctuk't.

lingfisher, kwákwole.

pigeon, hámō.

humming-birl, stustis.

secen, Hóken.

martin, spéeslōs.

Jren, stḱmtEm.

snalie, ôtlkai.

toad, wigelgailiat.

frog, hóham.

lizard, séskwatl.

ant, íbāqūȳì.

corm, séske.

ưsp, māmãlawéustuy.

housefly, qúxqaiȳo.

cron", skékak:

grouse, nōmHōm.

salmon (genrie), stétlisten.

" (spring), yómute.

" (coboe), kwōmaikça.

" (looj), séanñ

,. (stcel-head), skańmg.

". (sneli eye), súkai.

" (humpluteh), hinōn. trout, skaikōwiq.

rod (rock), tsúckin.

, (med), töktök.

, (tom), saukcelënq.

star-fish, kwéitlein.

rorlile, s'llélōm.

sert-eggrs, :iunten.

"hale, kwénis.

halibut, prtílerla ( $m-n a)$ etítqa.

suallow, spélng.

bec, mitmillwé.

butterfly, kéläla.

„rasshopper, kaikk'wát [um.

spider, mấkwēça.

mosquito, sktcốs.

gulll, kwấkwī.

raren, skwíto, kwéti.

porpoise, kwódñt' (or -nit').

sturgeon, skwitwite.

ooliean ("cordle-fish"), swéawii.

flounder, qÉlaq Fn.

herring, slúwat.

smelts, stcútkīm.

oyster, klúqkluq.

innssel, tlanakum.

crab, qaílik:

eel, stibaçbem or símaçm Em.

elog-fish, k'wítete.

rlirm (generic), s'óckō.

" (large hind), smeçai.

" (medium size), sk'aíī.

, (small limol), skwbai.

seal, ísq.

\section{Trums of Consanguinity and Affinity.}

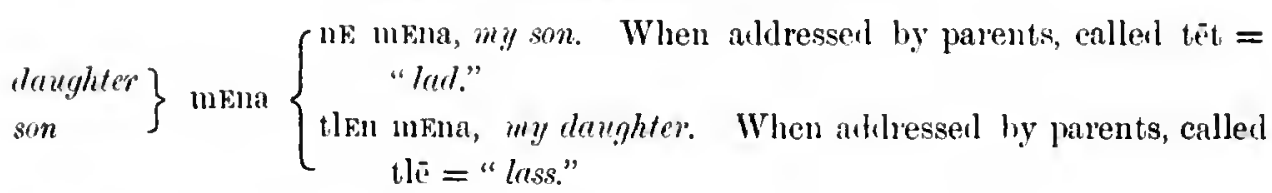

family, offsisming, thifonicel or túkwel.

mother, tan, when spoken of. When aldressed hy children, 1 a.

father, minn, " " " " " 

$\left.\begin{array}{l}\text { grandfather } \\ \text { grandmother }\end{array}\right\}$ séla. When addressed by grandehildren they are called, yálıa. great-grandfather $\}$ tcâmēuk: When spoken of collectively the suffix -tEn is great-grandmother $\}$ added, thus: tcámēnk.ten.

great-great-grandfather haúgēyuk. This term also takes the collective snflix great-great-grandmother $\}$-tEn.

$\left.\begin{array}{l}\text { great-great-great-grandfather } \\ \text { great-great-great-grandmother }\end{array}\right\}$ tsúpiyuk: Add suffix -tEn for collective form. $\left.\begin{array}{l}\text { great-great-grcat-great-grandfather } \\ \text { great-great-great-great-grandmother. }\end{array}\right\}$ tópiyuk (add-tEn) as above.

$\left.\begin{array}{l}\text { grand-son } \\ \text { grand-dauygter }\end{array}\right\}$ émaç or émats.

grand-parents, séla-tEn (coll.); grand-ehildren, ématsten (coll.).

$\left.\begin{array}{l}\text { mother's brother } \\ \text { father's brother }\end{array}\right\}$ tcāp'ts.

elclest brother.

$\left.\begin{array}{l}\text { eldest sister } \\ \text { eldcst cousin }\end{array}\right\}$ tcōtct. $\left.\begin{array}{l}\text { mother's sister } \\ \text { father's sister }\end{array}\right\}$ tcāp'ts.

youngest brother youngest sister $\}$ skaíEq.

The suffix -ten may be added to all these terms

elder of two brothers or sisters, tléwèt.

younger of two brothers or sisters, kúti.

youngest of many brothers and sister's, kéektī.

sister (by courtesy), alis.

$\left.\begin{array}{l}\text { brother's } \\ \text { sistcr's }\end{array}\right\}$ child, séliuuH; nepheves and nieees, séliuHten (coll.).

If the immediate relative be dead otl must be added; thus, séliuu-ôtl. This term is always employed when speaking of the dead, the ancients or the ancient time. It is probably the same particle as marks the "past" tense of verbs.

eldest ehild, tlëwēt, tcintl, tcêtcintl.

second ehild, kútī.

All others termed collectively, kekáktì.

last or youngest child, késktatl.

$\left.\begin{array}{l}\text { father-in-law } \\ \text { mother-in-law }\end{array}\right\}$ swênEm.

step-father, mā-nālaicin.

step-mother, tā-nālaícin.

$\left.\begin{array}{l}\text { father's brother's } \\ \text { mother's brother's }\end{array}\right\}$ wife, tā-nālaíein.

wife's

husband's

wife's

husband's \}brothers, sisters, contsins, nEqteūmaíc-tEn (coll.).

\}relations (taken collectively), nEqwénEm-t En. 
General Glossury of the Common Worls in Siteiatl.

able, ctcalém.

I am able, ctcalēm-tcin.

above, kúatam.

ofternoon, yelaú tekúkq.

again, tlal.

aid, help, kwinámç.

I will help you, kwinamçsētcin skwa. air, breath, späls.

alder-tree (almus rubra), qEqEqsai.

all, anke.

always, pālát.

he is alucays hunting, tē pālát tcātcấtc tlem.

ancients, people of long ago, tómōsōtl. and, ếE, íta.

anger, to, taiyākEmítEm.

angry, taiyek:

animal (gencrie), tītatculmīīq.

answer, replly, kwāl.

anybody; au-wät.

arise, get $u p$, kwōéc, kwaíēc.

arise, spring up (as a storm), tèlates.

arrow, haiyaitEn.

arrive at, or come to, tēmtlâllt, tesmeet.

ashamed, tlaiil or saiil.

ashes (hot), kwās, kwaileçāip.

ashes (cold), tcíbem or tcím Em.

ask, to, wálut.

I will ask him, wálut-tcin-skwa.

baek (to come or return back), yélcēn.

he went baek, tē sō yélcēn.

bad, mai.

bail, to, stlókotsot.

let him bail, nétlwela stlókotsot.

bailer (instrument), tlökómin.

bait, skwía.

bake, kwolic.

Uark, to, wōwóm.

bark (of tree), p'Elán.

baskct (used principally for lerries), spítcū. basket (used principally for clothes), kâtcā.

basket (used principally for roots, ete.), lấqai.

bay, āęEletc.

beach, tcau.

on the beach, a te tcau.

let us go down to the beueh; we sō it th tcau.

beat, to (with stick), súpetet.

beat, to (with the hands), supetet $\overline{\mathrm{a}} \mathrm{tE}$ tcấlic.

beat, to (with a stone), suk ${ }^{\mathrm{E} t} \overrightarrow{\mathrm{a}} \mathrm{tE}$ qaiels. beautiful, aiyúbic.

bed, lâas or lātl.

befool, to (anyone), k-āk ElnaHtas.

become or get angry, titaíyak.

below, down, ukqcī, qutluk; tlup.

bclow (under), klēpedétc or klēpenéte.

belt, $\mathrm{k} \cdot$ ait'.

beneh, chair, sukwenátcten.

bcnd, to, t'ốyūet, humkwḱt.

$I$ bent it, tế-tcin-liumkwâten.

you bent it, nūwil-tē-humkwet.

be quiek (to), kákīye.

berry (generic), skwolóba $0 r^{*}$ skwolóma.

bid, command, to, ótlōtem.

big, large, immense, tī.

billow, wave, yūlak.

bird (generic), skwēakwElkwālác.

lite, to, qutlt'.

black, kwōsếm.

blackberry, swōkwatl.

blanket (Hudson's Bay), pEk· kwōkw'i (whitc).

blankict (Hudson's Bay), kwum mōk't $(r e d)$.

blind, t'ípōs.

Ulister $(\alpha)$, spóya.

Ulister, to, pốya.

my hand is blistered, tê-tcin-pōya. 
blood, skwētl.

blow, to, pōt.

blow it! pot-tcuq, ad. litt., blow-you.

blunt, maínis.

boil (on the body), sćbEn.

boil, to, kwólstan.

the pot is boiling, mätlōkwôn tE kwólstan.

the vater is boiling, tāwutl māsuk tE sêwotl.

bone, cau.

borer (instrument); kwēsébim or kwēsémim.

$I$ bore, kwēsē-tcin.

both, s'kásait.

we will both go, s'kâsait kwums sō.

let them both go, sōs twelat.

bottle (of glass), lamáli.

bottle (kelp bulb), peáltcis.

bottle ( fish sound), kwop't te lauí.

bottom, qúsuk; tlup.

bow, stluk or sluk:

box, kwákwa.

boy (small), stōtôtemic méman.

boy (youth), swấwolōs.

braneh, sấlìya.

break, to, qutst.

" , (into pieces), qwatsau.

bridge, haícin.

bright, dazzling, kwiyím.

bring, to, kwutstuq.

I will bring it, kwutstuq-tcan skwa.

broad, wide, pēk:

brush (a), pēqulHēten.

bundle, kētálētc.

bush (small), sâlīya.

" (large), saldateíya or salnatcíya.

by, on, ni.

carry, to, yāe't.

catch, kwidat or kwinat.

cane, stúkēn.

cedar-tree (thuya gigantea), túqEmai.

change, transform, tūe or tōe. chew, tsaấm.

ehief, hēwus.

chiefs, hāwếwus.

chief (war), skalEq.

child, méman.

children, muméman.

chip, kIumén.

chipmonk, sqaikpêtein.

choke, to, pētsklấlt.

chop, to, k'lemúm.

ehop or fell a trce, Hétsnate.

clamber, to, tEélēsōt.

cloud, sấmuktl.

coffin-box, núākwa, QEk'um.

cold, tcim.

comb, ēkốsEm.

comc, to, anné, mē.

come, arrive to, kwutL.

command, bìd, Qất.

completed, finished, hớs.

continue, repeat, tlálet

$c 00 k$, to, k'wEl.

corpse, smaúkwa.

country, land, swíya.

crabapple-tree, kwehópai.

erooked, bent, skwósēt.

eross-eyed, çéçisōī.

cry, to, qaúEm.

cry out with pain, skwinēt.

eut, to, sitewât, tcet.

cut into pieees, kwōqt.

daily, auksélt.

dance, to, kwaiyélic.

daneer, $a$, skwalakwaiyēlic.

dangle, to, sáliakaim.

damp, kelkel.

dark, thúk·wom.

dawn, kwílakwi.

day, k-ēlt.

acad, kồi.

declare, say, to, çốçōt or sósõt.

decp, k-lip.

decr, ópit or hópit. 
deer-hiele, tlínauk.

desime, wish, to, sqats or qatl.

die to, kwố.

dig, to, kwenat.

divty, wíyam.

etisbelieve, qōqwaiaqát Em.

discuss, to, sōtīwáll.

dish, k'wäst.

dislilie, hate, to, mais.

$I$ distike you, mais-tônni-tcin.

distress, to, qEtlitl.

atire, to, nkiúm.

diver, $a$, snúkEmukum.

do, perform, to, stēqūas.

done, finished, hóis.

door, túktEn.

doun (of birels), stónatc.

"lream, to, utếtōt.

dream, $a$, sutêtōt.

drip, to, sítē

drop or fall, to (of person), pEl|pélen.

(of thing), pélEn.

drouen, to, mel.

le will be drowned, melas skwa.

duelling-place, home, nulawēm.

drum, mFnátsĩ.

dust, dirt, swíya.

carth, land, swíya.

eurthquake, súkwōm te swíya.

eut, to, êt]ten.

ciening, nánat.

ererything, tet-auko-stam.

E'tropean or uhite man, QiilétEu.

excmine, to, kwetét.

eccedingly, rery, stoqwét.

extraordinary, patlpesét or patlpetlét.

far, tcūk:.

fot, Qōs.

fieast, to, tlaaícin.

fiather, cimel.

ficl, to, támat.

fiylet, to, qaileiq.

filc, a, yúkamin.
I filc, yēy Ekamatcin.

file, to, yéykikama.

fill, to, litcac.

fill it ! litcacela!

find, to, sókt En.

I found it, tē-tcin-sôkten.

finish, complete, to, hơit.

finished, done, hơis.

fire, tcītcím.

fire-drill, skwétsakōp.

fire-place, tcītcīm-máli

firc-wood, skwaíuk.

fir, pElấlai or pelánai.

fish, s'tcälëten.

fisher, $a$, s'tcaltceílētEn.

fish-bone, Haúwa.

flame, wấtuk.

flesh, slêuk.

float, to, petléc

flood, pēuq.

flower, skwásum.

fog, tsEmsauikwolam.

food, sêtlten.

foretell or proplecy, to, tEqwonéQōs.

friend, siaíya.

freeze, to, tcimtcimall.

fresh, sweet, Haus.

gamble, to, kwâk-kwelt.

get into (canoe, ete.), ólōtl, ólēes, ólōs.

ghost, syquin.

girl, tlitlaclai or tlithlánai.

girls, tlítlintlīnai.

give, to, yat.

give it! yatela!

glad, merry, k'wíck'wic, kwáckwic.

glove, tlókwatci.

go, to, sō.

good, beautiful, fine, té.

gooseberry, stámōe.

grass, skwósits.

graceyard, smukemuíkwa.

great, steqwet ti.

greedly, skúdun or skúnuн 
green, klusếm.

grind, sharpen, to, tếEk Enīs.

groan, to, änēHêt.

grow, to (of things), pepấpā.

" (of man), tlótlōtl.

group (of people), nōkwálmīūq.

guide, to, säyúsels.

" $\quad a$, säsäyūsels or nuks-säyúsEls.

gum, pitch, kwElêtl or kwElēç.

hail, tselócin.

it's hailing, tsetselócin.

handsome, pretty, saiyúbic, aiyúbic.

hang down, depend, pélem.

hard, $\mathrm{k} \cdot \mathrm{luk}$.

hark, hear, to, kắnam.

hat, sīyâkōp.

hats, sīsīyákōp.

hate, dislike, to, mais.

heal, cure, to, laçmá.

heaven or skyland, kwátem.

help, to, kwinamen.

help him! kwinamet-tcūq.

he, him, tē tế-tloms.

hemlock-tree, kwílai.

hiecough, to, hâmēk:

$a$, cấmēk:

hide, to (person), kwālếmōt.

" (things), kwâlic.

hiding-place, kwâlten.

hill, skūmêt.

him, tE tEnitl.

his, sna (when person present).

" snas (when person absent).

hold, to, klālát.

hold it ! klālátela !

hole, slepēóQ.

hook, to, kōīyōk.

home, améwit, yốa, ȳū, ameut, úlawēm.

home-sick, yīám.

hop, jump, to, wétēm.

horn, wudaú or wunaú.

hot, kwās.

house, tlímstan, úlawēm. houses, tlâtlumstan.

honse (small), tlétlumstan.

hunger, skwấī, skwốī.

hungry, kwākầ.

hunt, to (large game), tcátlem, tcấtctlem.

” (small game), hailếEk.

hurry, to, tsătsaiy Eq.

husband, skwäkuts.

$I, m e$, te sályū $o r$ sályū.

ice, spếu.

island, kwÉtsa.

Indian, skálmīūq, kálmīūq.

infant, skâkklatl.

inspect, examine, to, kwEtét.

inside (of house), âstūe.

instructions, sQūnâl.

interpret, to, $\mathrm{k}$ wékwētlkEn.

interpreter, nūks-kwékwētlkEn.

is, are, nëtl.

itch, tciên.

invite, to, ò or ót.

jump, to, QêtEm.

keep, to, nēste.

kettle, kwelistên.

kind, good, éī.

knife (small), tlátl'tcten.

" (large), tláteten.

" (pocket), Qéôqus'.

knock, to (at a door), sukacaút.

knock or strike, to, súk nut.

know, to (intuitively), teqwánōm.

" tEqnēQ.

ladder, tek'Esót-tEu.

lake, siláttl.

lame, sQótsenatc.

land, swíya (when spoken of on the water it is called tlalt).

language, kwấlten.

lrivgc, big, tī.

laugh, to, qaíEm.

laughing, qāqīem.

lazy, óōmat.

lazy person, sóōmat. 
leak, to, kúkElEın.

leaf, sálīa.

lean, slêakēt.

leap (as a salmon in water), mák $\mathrm{Em}$.

learning, instruction, stếuam.

learned, stútēūc.

leather, cítctcai.

leave, go, tsō or sō; sōla! go! sō-tcin,

I am going.

lend, to, kwébilis or kwémilis.

liar, ếwon, qEqéwon.

lice, metcín.

lick, to, tsếmēt.

lie, to, qaíaqēwonem.

lie dead, to, skôiyêt.

lie down, to, saqaíç.

life, swáyi.

lift up, to, tcēt.

light (opp. heavy), Q1́ EQā.

" (opp. darh), k'ēlt or k'áilt.

" (of moon), cälít.

„ (of torch), kwéyèm.

lightning, pāpeléEq.

like as, similar to, swēnấm.

line, Qćlem or QaílEm.

little, tsótsī.

live, to, ni.

I live, nī-tcan.

liver, pōkpok.

$\log$ (in the forest), síya.

" (in the water), kwetlai.

logs (in the forest), síyam.

" jam of, petsêt.

lonely, sīlsíluk:

long, klāk't.

look at, inxcstigate, to, kwetas.

"for, search, to, sélët.

lose, to, Qaqaú.

loose, kaíakaiya.

loud, ténēsōt.

love, to, sqat.

lover, swátela.

he is my lover, netll nE-swátela. lump, skuméq.

lungs, tlākwamálī.

man, stómic.

many, kEq.

maid, swáwelōs tlánai.

maple, k’úmōlai.

marrow, nipcin.

make, to, neất.

" a fire, tcīmīekwōp.

make whole, restore, to, tluk'wamát.

marry, to, swākáç.

married woman, swākâts.

" man, sīyaktséū.

mark, to, Iuúlem.

mask, sqoioqai.

mat (for beds), klíwai.

" (for food), sēlósēten.

$m e$, sályū.

meat, slếukQ.

medicine, stélmēur.

meet, to, aíakwōst.

melt, to, yauq.

men, stémtōmic.

mend, to, lāsmát.

message, sHwam or sqam.

midnight, nícic.

mind, kwâlēwon.

mid-day, kaúkūн.

mine, tsEna.

mistake, nätcin.

mix, to, nélit.

mock, to, tatāmekén.

moccasin, stlúkcin.

moon, cálcäl.

morning, kwêkwi.

morning-star, kwékwī-kwósEn.

mountuin, smânèt, skwêtlai.

morsel, bit, tíūyet.

move, $t o$, yúalōm.

" it! yüalōtela!

" to (from place to place), yūalósōt.

much, many, kEq.

mud, tsētsēek: 
murder, to, kwóyiluk.

murderer, kwōkwōyíluk, kwōkwaiyíluk,

kwōkwaímaç. (The last two terms are employed when more than one person has been murdered.)

naked, sleuwétsa.

name, skwic.

narrow, tséatE.

near, stesết, tetsêt.

necdle, $\mathbf{k} \cdot$ Enaíy $\overline{\mathbf{u}}$.

night, nät.

no, Qā.

noise, Qálōkōm.

none, Qāuk't'.

noon, kaúkūH.

not, Qāuk't'.

now, tcitūā, tcat.

nut, k'upaútl.

of or belonging to, tle.

offer, to, yätóyät.

offer it! yatóyatela!

oil, SQES.

old, k·lákatl, stōtélemit.

old man or woman, QāmēmanEs.

on, by, nī or nē.

orphan, wänwánēm.

outside (of a thing), āstlkám.

" (of a house), âstlk:

out, tluk.

owe, to, skwēmelas.

pack, to, yactem.

„a, sīyacin.

paddle, sk úmōl.

pail, tlōkómin.

pain, swoét.

paint, yútlemēm.

" to, yôyôtl.

parents, klāqkláq.

pass, to, yílau.

path, trail, cautl.

paw, spákin.

peel or skin, to (roots, etc.), tlōpiyóst.

" to (bark from trce), slukwếyūst. pecp, to (through a hole), tcilakwálōsem.

" (from behind tree, etc.), wêlem. people, tE skálaumīūq.

perhaps, êīoãwómEla.

pipe, patlum-málli $=$ " smoke-place."

pipe-clay, stúauk:

pitch, gum, kwúlētl.

pierce, to, нōp.

place or put in water, to, puksăt.

play, to, kāksém.

he's playing, kākáausēm.

plate, kwâkwetlt (dim. of kwātlt, dish).

point (of thing), èiyalín.

" salīyuk:

" at, to, hópem.

" it out! hốpet.

poison, tsuqten = "rattlesnake."

poor, necdy, sćQēEm, naúdō.

portrait, skélos.

potlatch, klEénuk.

power ( physical), saíyim.

prepare, make ready (food), neúmtEm.

presently, in a little uhilc, QāQōQES.

prick, to, súkęom.

push, to, yótsem.

" it, yôtsōt.

put, to, kwaits.

put in the mouth (as a bit), yätkăit.

put in the fire to cook, héwēt.

put in the mouth, skómōts.

quarrel, to, kwālmētaútl.

quict, calm, tsósōm.

race, yētl.

rain, to, tcitl.

rain-storm, stcitl or ctcitl.

rainbow, sä́tci.

raspberry (black), sk'óma.

" ("rcd-cap"), saíü.

" (salmon-berry), k'wéEk'wel.

raw, qēts.

ready, hóiya.

red, kwEmēm.

red-paint, temtl. 
red-hot, Qaíhōls.

reflection (in water), māmåkīō.

regard, to, nEétem.

remember, to, hākwát.

reply, to, kwäl.

repeat, continue, to, tlálet.

rest, to, kwāneusem.

restore, make whole, to, tluk wamát.

return, yíliein.

rich, wealthy, hếwEs.

ring, stelêtc = "round thing."

" (for finger), tsōwätēkwóīya.

ripe, $\mathrm{k} \cdot \mathrm{w} \mathrm{El}$.

river, stôlō.

rivulet, stéltōlō.

roast, to, kwElac.

roast it! kwelacila!

"to, the hands or paws,

tEp Enatcóìy Em.

roast, to make them drip oil,

tepenateóiyem.

rob, to, teilótl.

robzer, stciltcilótl.

roof, éläto.

root, kweúminate.

rope, QêlEm.

rotten, tluk.'k.

round, pelék, péluk.

$r u b, t o$, tsúkwum.

rub it! tsuktíla.

run, to, yitl.

sail, to, pótēn.

"a, póten.

salt, klấtlum, kwơtlōm. (The latter is older term.)

sait-water, kwótkwō.

salty, kwớtōm.

same as, similar to, sukwếman.

sand, kwélakwèl.

sap, sqúmets.

say, to, kwīl.

save, to (by clutehing at something), tlalsám. seald, to, kwâsau.

" it! kwāsáwut.

scar, sk:aiyétl.

scold, to, q $\overrightarrow{\mathrm{e} w i t}$, kaiyéste.

serape, to, sấqūm.

serateh, to, k'aik'wem.

seream, to, kwák'ët.

search, to, tsếtsēlem, sélēt.

sea, sếnkō, kōtlkō.

see, to, kweném, sóqtem.

sell, to, waiéc.

send, to, āmākác.

severe, winâkwEs.

sew, to, pāts.

" it! pâtsut.

she is sewing, pâpätsEm.

shadow, stātsīmēn.

shake, to, yékwēt.

shake it! yēkwêtela!

shallow, éelt.

shame, tlaiilátsus.

shaman, oólankk.

sharp (of tools, ete.), ế̃ nis.

sharpen, to, têkenist.

she, sē, sē-tlōm, tlā, tlā-tlōm.

shine, to, ēìálōs.

shoot, to, tôtsem, tôtssōt.

short, k'aíak'Q.

shout, to, k'ait.

show, to, yôtsōt, saiūst.

show, appear, to, êna.

shrink, to, qésēçōt.

shut, to, tuk't.

shut the door, tuk't te cautl.

sick, kukelāsélem.

sight, maíyil.

silent, tôsōs.

sing, to, têlēm.

singing, têtêlem.

singer, stéltēl.

$\operatorname{sink}$, to, $\mathrm{mEl}$.

sit down, to, $\mathrm{t}^{\mathrm{k}} \cdot \mathrm{e} \mathrm{c}, \mathrm{t}$ tek aic.

sit, to, t'kenatc. 
shy, tsōk:

slap, to, tlúket.

slave, skíots.

slide, to, qệtem, quiequaín.

slcep, to, étōt.

slcepy, étōtam.

slip, to, sitlk'cín.

slow, ôyōm.

smart, quick, kléklē.

walk quickly, klécin.

smell, to, hăkwōm.

smother, to, kupósèt.

smile, to, pétcēmōs.

snoke (from pipe, ete.), pátleu.

$"$ (from fire), kwitlem.

snecze, to, hásem.

snecze, $a$, cásEm.

snore, to, qōkwét.

snow, skwómai.

snow, to, kwōkwōmai.

snow-shoe, nūkwélcin.

soak, to, slúk'um.

sock, kwélten.

soft (to touch), kéakè.

sold, Qaiic.

solid, tuk', túkēwon.

someone, watásyE.

some, skwuk.

song, stếlEm.

soon, klē.

soot, kwaiêtcūp.

soothe, to, tcéyit.

sore, qus.

soup, skwókwatlkō, sték Ela.

sour, tótsōm.

sparks, pētcém.

spawn (salmon), kúleq.

speak, to, kwāl.

spine, Haúwa.

spit, to, tlōkts.

spit! tlokt'Ela!

out to, pektas.

splash, to, kwécill. splinter, skwukêt, skwêkwukīt (dininutive).

split, to, kwuk'ut.

spoon, tcáwai.

spring (of year), tEm, paíy'u.

" (of water), málōm.

spruce-tree, tcétlpai.

squecze, to, pétsèt.

squint, to, Ińlak`Elōs.

stab, to, tlúkem.

stale, kwutlum = stinking, hal.

stand, to, kwaiếc.

standing, kwaiécit.

star, kwósen.

sterve, to, kwaikwaíñ.

stay, to, skwinés.

steal, to, tcílótl.

steam, pōuwéim.

steps, ladder, haicin.

stew, s'pinicấn.

stick, to, thúkōm.

still, yet, tlal.

stink, to, kwetlém.

stink, bad ollour, skwetlêm.

stone, qaíkls, diminutive qaíqaisls.

stony, qaiqaielsam.

stop, to, kaíyè.

stoop, to, kutséc.

story, myth, sQádiam (if thought to

record an actual or historic event

then called wonańq).

straighte, tōk"tōk:

strap, k-⿳亠二口犬 $=$ "belt."

" (for basliet), k'ấtla.

strawberry, télēuk.

stream, stốtelō (diminutive of river).

stretch, to, tsúk Et.

strilie, to, sépetas.

stripe, suliet.

strony, ēīyśm.

stumble, to, tentếnim, tlatckwóicin (= to

catch the foot in something).

stump, ts'úk'Enatc. 
stutter, to, âtcetc.

stutterer, nūks-ấtcetc.

suck, tớkōm, tôkōt.

sucker, $a$, nūks-tōkōm.

summer, tEm éyōs.

sun, siaíyō:.

sunbeam, swêil, yicinálitso.

sunshine, swélēt.

sunrisc, wēwēléō, êcêna te siaíyōk =

"appearing the sun."

sunset, ấum te siaíyōk:

sure, wenaúr.

surprise, to, teilem.

swallow, to, mōkwEn.

sweat, to, yākwum.

sweating, yãyakwum.

swell, to, tlāk:

sweep, to, ékwumēūH.

swect, k'utl.

swift, k-ék-ē.

swim, to, QáQElēm, nEsím.

swimming, QáQăQ elēm.

swing, to, mốīmóīsum, mơīmóiisōt.

tail, sốpenate.

take, kwinat.

take home, to, amếwit-enōm.

take up in the arms, élemt.

tale, Qáoìam or soátoìam.

tall, klāk't.

tame, kwálkwal.

taste, to, teát.

tcach, to, têyūcam.

tear, to, puqt.

tearing, púqtpuqtem.

tear (lacrima), kElōs.

tell, to, táaut, tägoin.

telling, tátäQom.

tent, sīlańto.

testicles, mÉtcin.

that, tīi, te nē à tā.

thau, to, yaíyauk.

the, te (masc.), tle (fem.).

there, ếna, tas, ta nē ā tā. they, títetlōm.

thick, petlt.

thief, tciltcilótl.

thin, pépel.

think, to, sốtēwon, kwấlēwon.

thirsty, kókwām.

this, ti.

thou, thee, tE nūwil, nūwil.

throw, cast, to, suk'um.

throw away, to, nemác, nemácac.

thunder, Qātkém.

thy, thine, ásena.

tickle, to, kekaíyūsak.

tie, to (a knot), k·ēsêt.

tiny, small, soçì.

tired, weary, k.óēyūs.

to-day, te kwấl or kwéil.

to-morrow, útlkwīas.

tooth, yinis.

tooth-ache, qus tE yinis, ad. litt. sore the tooth.

touch, to, kalisat.

$"$ (one on the shoulder),

qāmālaútcistem.

track, yīcínamin.

trail, eautl.

transform, aiyúwatem.

trap, Húcin.

" (pitfall), hāpêtuk.

” (log), pākawớs.

" (spring), cátkūs.

travel, to, yōilósōt.

trec, síya.

trees, sfyam (more literally "forest,"

place of trees; $c f$. hópīt, $d e c r$,

lópitam = place where deer abound). tremble, to, sekwim.

try, to, teát.

tumble, pōks.

tunnel, slipéūu.

turn, to (back), yilicín.

" (round), yilklấtcEm.

" (face down), mÉlōs. 
Journal of the Authropological Institute, Tol. IXXII, 1904, Plate I.
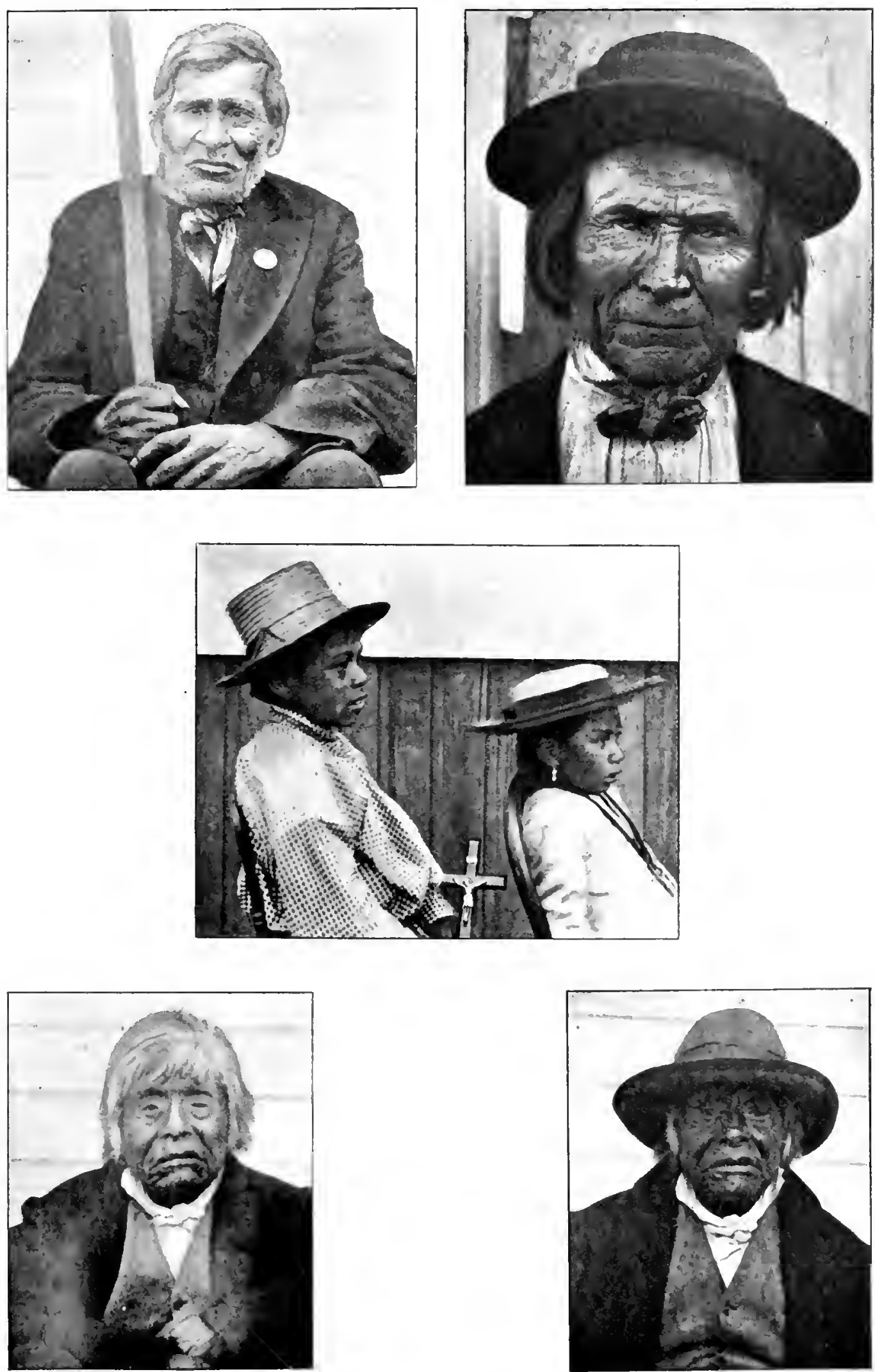

TYWE OF SIULATL INDIANS.

THE EIINOLOGY OF THE SICIATI. 
tvilight, çôsōs.

twist, sEltcät, sElētc.

$u g l y$, mäyôbic.

uncover, to, penóot.

under, klêpam.

understand, to, tuqEnéuq.

unfasten, to, k·ēsem, k-étatict, yuk't.

valley, smétukQ.

very, steq wét.

village, tlélnōp.

visit, to, skwinếs.

voice, sásämin.

vomit, yóyōkwot.

wait, to, kaiyế, tluk áts.

waiting, tlúk'am.

wake, to, yấwum.

wake him up! yawatela!

wake up ! kutósem!

walk, to, émae, émēwac.

wall, k'ulkōten.

war, qêlēEq.

warm, kwās.

warrior, cEmán.

wart, skōkōpía.

wash, to, tsōHt'.

wash yourself! tsuHtsōHtEla!

wash away (by torrent), têselnq.

wateh, to, lé Eluk.

water, séwōtl.

wave (billow), yólauk.

we, nēmōtl, tlnēmōtl.

weak, mīmáyèt, kelkElmōt.

weary, k wónīyūs.

wedge, Hôet.j

weep, qaúEm, hấwōm.

weir, tukốs.

when, kwEs.

where, kwÉntea.

which? nitcẩ?

whisper, to, tlâkam.

whispering, tlấtlākam. whistle, to, Hópōm.

whistling, HớHōpōm.

white, pEk.

white paint, skwōq.

who, wat.

whose, túwat.

why, wherefore, stealím.

widow, sīyâten.

widower, sīyáten.

wide (broad), pèk:

wife, sīyấkçū or sīyákçau.

win, to, k'lukwêluk.

wind, spāls.

window, kwēkwīnósten (modern term).

" kwấwōs (old term).

wing, címal.

wink, to, saikwósEm.

winter, tEm stcim, or tEm sótēte.

wipe, to, tsuk't.

wise, klãkéwon.

wish, desire, to, sqats.

witeh, tcintcénem, kwenéwesals.

with, k'ütsêt (= together), skúmēt.

I'll go with you, sôtcīn skúmēt.

woman, slánai or tlấnai.

women, tleslấnai, tletlấnai, tlentlấnai.

wood, skwaíEq.

woods (forest), çêttcim.

wool, k'wấsten.

wreneh or dig out, wátat.

yawn, hāhếū.

year, sīlámīn, skwómai (= snow).

yell, to, kwák'ut.

yellow, k'lesém.

yes, éa, $\bar{o}$.

yesterday, tcilấkatlōtl.

you, nūwilap, nūElap.

young, méman.

youth, wấwelōs or swấwelōs.

youths, wāwếwelōs swāwêw Elōs. 
[Repruted from the Journal of the Anthropological Institute, Tol. XXXIJ, January-June, 1904.] 
3.

REPOIT ON THE ETHNOLOGY OF THE STIAATLUMH OF BRITISH COLUMBIA. 


\section{REPORT ON THE ETHNOLOGY OF THE STLATLUMH OF BRITISH COLUMBIA.}

By Charles Hull Tout, Local Correspondent of the Anthropological Institute.

[With Plate XV.]

This paper contains a summary of my studies of the Stlatlumu tribes, one of the interior divisions of the Salish of British Columbia.

I have to acknowledge my indebtedness to the Goverument Grant Committee of the Royal Society for substantial help and encouragement in my work in the form of a third special grant of $\mathfrak{E 4 0}$; to the Government of British Columbia for a grant of $\$ 100$; and to varions kind friends for other help and assistanee.

It is gratifying to be able to report that my studies of the Stlatlum, popularly known as the Lillooets, after the name of one of the chief rivers of their habitat, have been fruitful in bringing to light a body of new and interesting information relating to tribal and sub-tribal origins; to the source and signifieance of personal and group names; to the nature and eharaeter of personal and hereditary totems; and to certain magieal ceremonies, which in some striking features resemble the Intichiuma ceremonies of the Arunta and other central Australian tribes, ancl which are earlied ont for a like purpose.

Indeed, my notes will recall to those familiar with Messrs. Spencer and Gillen's works on the central and north-western tribes of Anstralia many features of the culture of the natives of that eountry.

One of the more striking of these resemblances is the common use, among the two peoples, of mystic and secret names. I eall attention to this fact because I believe we have yet much to learn eoncerning personal and group names as they are fonnd among primitive races; and certainly the fact that we find two peoples, so widely separated and so physically dissimilar as the black-fellows of Australia and the natives of Ameriea, holding similar views in this regard, makes it clear, I think, that we are here dealing with some deep-lying universal concept of primitive man, the nature and significance of which is of the highest importance to us in our studies of primitive life and eulture.

With this thought in mind I have paid special attention in my investigation to the name systems of the Stlatlumn and eognate tribes. I was unnsually fortunate this year in securing the services of a highly intelligent and elderly Indian who possessed a workable knowledge of English, and whose memories go back to times and events ante-dating the settlement of the whites in these parts. His affiliation to both Halkōmélem and Stlatlumu divisions, lis personal knowledge 

of both tongues, and his close acquaintance with all that concerned the inner life, thoughts and customs of the Indians, enabled me to gather from and throngh him much long-desired information on some of the doubtful and obscure points in Salish culture. When possible I sought confirmation of his statements from other Indians and invariably found them accurate. My intercourse with him has left no loubt in my own mind that such information as I gathered from him is wholly trustworthy.

Those who have followed my examinations of the Salish dialects will fincl much to interest them in the peculiarities of the StlatlumH speech, which appears to occupy a transitional position between the dialects of the interior and those of the Delta and Coastal tribes; the specch of the upper or northern tribes having many resemblances to the N'tlakápanue and that of the lower to the Halkomélem, thongh the dialect as a whole is distinct from that of either of these divisions.

\section{ETIINOGRAPIIY AND SOCIOLOGY.}

The Stlatlumi occupy a considcrable extent of territory and were formerly a strong and populous division. Since the advent of the white man, however, they have, like their conques elsewhere, greatly decreased in numbers, and quite a third of their old villages are now wholly abandoned. Like most other American tribes their settlements are confined to the borders of the lakes and rivers of their habitat; and as these run more or less in a continuous line north and south, their territory is much longer than it is broad, the distance between the most southern and the most northern tribes being upwards of two hundred miles. The intercomrse between the upper and the lower tribes was therefore never very close $01^{\circ}$ frequent, and it becomes easy to understand how the dialectical differences in their speech arose.

In the accompanying map (Plate XV) of the StlatlumH and adjacent territory I have marked the approximate sites of the settlements of the StlatlumH. Those marked with a cross are still occupied; the others are now deserted and have no occupants.

The villages, as will be seen, are more or less bunched into two groups; one on the upper waters which flow north-east and one on the lower which flow south. This break in the settlements corresponds to a natural topographical one. It is here that the water-shed or "divide" is found which causes the rivers and lakes to run in opposite directions.

In former times the settlements of the Stlatlumi proper did not extend so far south as at present. Prior to the advent of the "gold rush," about the middle of the last century, the Halkōmélem territory took in the whole of Harrison Lake and some portion of the Lillooet River; but with the discovery of gold in the Cariboo region many of the miners instead of going up the Fraser to Yale, chose the Harrison Lake ronte and made Port Douglas their port of clebarkation; and in consequence a populous little town soon sprang up here. This attracted the Stlatlum tribes above in such numbers, that in a generation the 
Halkōmélem speech of that eentre gave place to the Stlatlumi, which has ever since been spoken down to this point.

The southernmost tribes are, therefore, of mixed descent, being partly Halkōmélem and partly StlatlumH. All the settlements south of Port Douglas on the Harrison Lake and beyond, as the map shows, are now deserted and unoceupied, and the nearest Halkōméleın village is that of the Stseélis of whom I treated in my last report.

Following will be found the names of the settlements above the StsEélis as given to me by my chief informant "Captain Paul" of Port Douglas. I have given the meaning of these names as far as now ascertainable. All those on the shores of Harrison Lake, up as far as CQómluks, were formerly Halkōmélem villages but are now numbered among the Stlatlumu for the reasons I have given above. From this point northwards to far distant 'NQoícten stretehed the original settlements of the Stlatlumin in the order here given.

1. "Lūqskála," place of many berries, ef. "skäl," red hucklcberry. This settlement was noted for its berries.

2. "Hetcípsum," narrow neck, cf. tepsum, ncck, so called because here the Lake narrows to about a third of its usual width.

3. "Seátete," meaning unknown.

4. "Mil'ku ${ }_{\mathrm{EHyin}}$," standing strong, ef. "Smaleku," elk shirt, and "Hyin," foot. The mountain here stood strong and impregnable like a man clad in elk-skin armour.

5. "Cái," Doctor Point. Name has reference to a shaman who was supposed to live here at the time when the Qals wandered about the country. There is a myth in connection with it.

6. "S'kutzấs," butting, so called because, if one paddled on here, one would run against the head of the lake.

7. "Qũaqtea," little lake. This is a small lake that runs into Harrison Lake. On this Fort Douglas is situated.

8. "Tekwätlōe," meaning unknown. This place is used now as a fishing station and root ground.

9. "Lelä́pin," Fishing staye. This was a noted fishing ground. The shore is rocky here and the waters swirl by. The salmon take this course and the Indians erect staging over the water upon which they stand and fish with the dip-net. Hence the name.

10. "CQómluks," falling on the nose.

11. "Skáqicten," shallow water. The river here spreads out and becomes very shallow.

12. "SkaitEn," watcrfall. This was and is a great fishing ground, the "fall" in the river here causing the salmon to congregate. This is one of the most populous settlements. 
13. "Cuqtein," narrow strait. The mountain here comes close down to the bank of the river and forces travellers to walk on the "beach." cf. "Cúqatc," beach.

14. "Sämákwäm," meaning unknown.

15. "'Nk'èluk," head of the river. There is here now a settlement on each side of the river with a church in each place.

16. "Énmetcūc," this term has reference to the narrowing of the lake at this point. Close by here is one of the loftiest mountains of the district. It has a peculiar cleft in it. It is ealled "Encūkata," which means split like a erutch. At the time of the traditional flood those who eseaped managei to do so by climbing this lofty mountain. Paul affirmed that the drift wood of the flood could be seen in the cleft of the mountain above the line of timber.

17. "Pokpák'otl," plaee of many store-houses. These store-houses were erected on poles and stood from four to six feet above the ground. These are always found in localities when the ground will not permit of digging the commoner teépōn or stone-cellars.

18. "Zāunks," long puint or nose. This spot is now the grave-yard of the district. Fifty years ago it was a populous villnge.

19. "Qaitlólanq," meaning unknown. Tradition says that it was here that the wolf people used to live. Wolves are supposed by these Indians to be dogs gone wild.

20. "Eneúk," split. There is a mountain opposite the village here witlı a great cleft in its summit, hence the name of the village.

21. "Züzílkwa," eddying water.

22. "Lilùztól," the real or true Lilūet. The suffix ôl here has the same meaning as the suffix $\bar{o} e$ of the N'tlakapamuQ, the final vowel " $e$ " having been ehanged apparently to " $l$ " in the StlatlumH.

23. "Qulpańtlten," portage, cf. "Qulpautl," to haul a canoe over the ground.

24. "Nūk'ítkwa," meaning unknown.

25. "N'kāitem," head or souree of ereek.

26. "S'leôe," head of the lake.

27. "Tcalátl," lake.

28. "Hōsúlken," white-haired mountain goats.

'29. "Skumkâin," head of the river. This was a populous settlement in former times. It is now the site of the Govermment salmon hatchery.

30. "NQoicten," smiling. So called because the salmon were taken here in large numbers and the people were therefore happy and glad.

The soeial organisation of the Stlatlumu differed somewhat aceording to the locality, the upper tribes approximating to the simpler, looser social system of the neighbouring N'tlakipamuQ, and the lower to the more complex, formal system of tlıe Halkōmélem tribes. For instance, we do not find among the upper tribes that 
threefold division of the commune into chiefs, nobles, and base folk, which prevailed among the Delta and Coastal gromps and which characterised the lower tribes with Halkōmêlem affinities.

The office of headman or tribal chief among the StlatlumH was, as elsewhere among the Salish bands, theoretically elective but practically hereditary; especially among the lower tribes. The power and influence of a chief in any given tribe would scem to have depended upon his personal qualities and charncter, the more able and iutelligent he was the greater and wider his influence; and one might lay it down as a general rule that the office of headman in a Salish tribe was held by the ablest, most intelligent and therefore the wealthiest man in the tribe. But the office in the lands of even the most influential and wealthy was hedged with many limitations, autocracy in any form being contrary to the spirit of Salish institutions. A Salish chief was rather a patriarch than a ruler. He was essentially the tribal father and stood to the tribe as a whole on much the same footing as did the several eldermen to their individual families; and it wonld appear that he rarely, if ever, entered upon any serious undertaking without first learning the opinions of the tribal elders and consulting with them.

This restricted power and authority of a Salish chief is clearly seen in the fact that he is not necessarily the head or director in all unclertakings. For example, if he were not the most noted warrior of the tribe he would not direct warlike operations, or lead in attack or defence. This office and authority was always vested in a man noted for his personal prowess and skill in warfare.

It was the same in hunting. When a hunting expedition was set on foot it was not the chief who usually directed the movement, but the best and most successful hunter in the tribo. And thus it was with all public offices; the man most fitted for any particnlar post was invariably chosen by his fellows to fill it. But while all other offices seem to have remained elective, circumstances have tended to make that of the tribal chief hereditary. It is easy to understand that the son of a wealthy and influential chief stood a better ehance to be his father's successor, other things being equal, than any other man of the tribe, more particularly when both father and son paved the way for this succession by a generous and discreet distribution of presents; and thus it is not difficult to perceive how an office originally elective became, as we now find it among the Coast and Delta tribes, practically hereditary.

It was this hereditary character of the chieftaincy which gave rise to that threefold social division of chiefs, nobles, and base folk, which prevailed among the lower Salish tribes. As soon as the office of Siám became hereditary the ling or chief held a place apart from the rest of the tribe; and thus a princcly caste is formed. The hereditary character of the chieftaincy among the upper StlatlumH and the consequent creation of a "royal" caste was scarcely accomplished when the disrupting iufluences of the white man began to make themselves felt; but annong the lower Stlatlumit the chicftaincy had become virtually bereditary, and the division of the tribes into chicfs, nobles, and base folk was the prevailing system. 
We see another instance of the democratic eharaeter of the Salish mind in the position of the "divisional" heads. In many groups or divisions this headship received scant reeognition. The office was generally held by a local ehief whose wealth and influence excelled those of all others, or whose village was most populous and flourishing. The Stlatlumn had two such chiefs, one for each group, the upper and the lower. These chiefs or divisional heads had nothing to do with the local affairs of the other villages. Their functions seem to be to represent the group or division as a whole and look after its interests. Each local community had its own headman and looked after its own affairs. In the earlicr listory of the Stock this local authority and direetion of affairs would seem to have been shared by all the eldermen of the village or commune in common; or perhaps it would be more correct to say that the elderman of each family directed the affairs of his own household independently of all others; for the original social unit of Salish society was the family not the village commune. A primitive Salish community was a congeries of independent family groups, each ruled and directed by its own clderman. Every loeal community or village was eomposed of a greater or less number of these independent self-ruling families. These families comprised all a man's blool relatives on the father's side, eommonly represented by three or four gencrations, all ocerpying the same permanent dwelling together.

Next to these family groups, thus constituted, were the kin-groups. These comprised all a man's relatives on both sides of the family, that is, all his mother's blood-kin as well as his father's, to the fifth or sixth generation.

\section{Marriage.}

The marriage customs of the Stlatlum differed somewhat in certain features in the upper and lower tribes. At Qaaqtea (Fort Douglas) and the neighbouring villages the ceremony was conducted much as follows: When a boy had arrived at marriageable age his parents would ask him if he lookel with favour upon any girl of their aequaintance. Upon lis replying in the affrmative, and on learning his choice, they would select one of the eldermen of the kin-group to act as intermediary. It was not etiquette for the youth or his parents themselves to make the first move. This old man would pay a visit to the girl's parents and diplomatically sound them as to their willingness to accept his young kinsman as their son-in-law. If the girl's people considered the match desirable they would signify their consent and a day would be fixed for the visit of the bridegroom. The relatives and kinsmen of both parties now made preparations for the ceremony. These consisted chiefly in cooking large quantities of the choicest food. The parents of the youth opened their treasure chests and set aside sueh of their contents as was needful for the proper carrying out of the ceremony. The youth limself goes in to the forest and ents a large armful of the best fircwood. This he takes home and places with the wedding gifts to be borne with him when he sets out for tho marriage ceremony. Everything now being ready and the day appointed having duly come round, he sets out for the home of his father-in-law accompanied by his 


\section{$13 \pm$ C. Hill Tout.-Report on the Ethnology of the StlatlumI of British Columbia.}

The subterranean winter dwelling, called in the Lilūetól tongue "écitken," of which no specimen now exists, was, as far as I could gather from the descriptions of my informants, similar in construction to this class of dwelling among the interior Salish which has also been described by earlier writers.

The tcitūe, or house proper, was, as I have said, of the long-house style. These dwellings were found mostly among the lower Stlatlumir, who would appear to have borrowed them from the neighbouring Halkōmélem tribes, this kind of structure being characteristic of the coastal rather than of the interior tribes, where the climatic influences largely differed from those prevalent on the coast.

These houses do not appear to have been as long generally as among the Delta tribes, where continuous structures of from 100 to 200 yards were not uncommon fifty years ago.

Among the Stlatlumf the internal structure of these houses differed from that of any I have described heretofore. Each family group was customarily divided off from the rest by permanent wooden partitions. As the Smētlás, or winter ceremonial dances, were not practised by the Stlatlumn, they had no need of the long open structure of the Halkōmélem and coastal tribes, which stretched from end to end without permanent divisions, and often without any divisious whatever. Each "family" was entitled to a space 60 feet long. The width of the building varied with the natural condition of the site, ranging from 25 to 50 feet. The style was usually of the half-gable or single slope type. The roof was always of very slight pitch, being customarily used as a platform upon festive and ceremonial occasions. There were two entrances, a back and a front one, for every two compartments. These latter were divided off from each other by a passageway about 6 feet wide. In the walls of this passage-way, at about the centre, was a doorway on each side which gave access to the compartments. Within each of these compartments there dwelt usually four fire-groups, one to each corner. These firc-groups made up the family, and were invariably of blood-kin to each other. They were sometimes made up of four generations of the same family, sometimes by a group of brothers with their wives and children, sometimes of a father and his married sons, and sometimes partly of one and partly of the other; but all were related to one another by blood ties, and no marriage was permittel between them.

Among the southernmost of the Stlatlumn tribes theso honses contained platforms around the sides of the interior, as among the Halkōmélem. These served as beds by night and as lounges by day. Shallow cellars were dug beneath them, in which was stored away the winter's supply of roots. All round the walls above the beds "nkailakiamten," or hanging shelves, were erected, on which the household's supply of meat and fish was dried and smoked.

Among the middle and upper Stlatlumi the bed platform was not in use. The bels here were formed of layers of fir branches arranged in a circle round the tire. Upon these the people lie with their feet towards the fire.

Their coverings, when they were wealthy enough to possess such, were 
blankets made from the hair of the mountain goat or from the skins of small animals sewn together. Deer, bear and elk skins were also in use anong them as winter eoverings. Among the lower tribes, where the raised platforms are found, layers of reed or swamp grass mats composed the beds. These are in common use to this day, laid directly upon the floor of their houses or on the bedsteads of the whites.

FOOD.

The food of the Stlatlumu tribes was much the same as that of their neighbours. It consisted in the main of salmon, fresh and dried, supplemented with the flesh of such animals and birds as they eould suare or kill, and the wild fruit and edible roots of their habitat. Both the latter were stored away in considerable quantities for winter use, the roots in shallow cellars under the bedplatform, and the berries preserved in a variety of ways. Some were dried after the manner of the currants of commerce, some were pressed into solid cakes, and others were treated in the manner described in my remarks on the food of the Síciatl. In the salmon season large quantities of these fish were caught and sundried or smoked, and afterwards stored away in elevated cupboards or storehouses. These structures were erected apart from the dwellings, their floors being raised from 4 to 6 feet above the ground, to preserve their contents from the camp dogs and other prowling animals. They smoked and dried the flesh of the larger game animals when their supplies exceeded their temporary wants. In the seasons when the salmon were plentiful they extracted large quantities of oil from them, storing this away in bottles made from the skin of the smaller salmon thernselves, from the larger guts of their game animals, or from the sounds or airbladders of fish. Their method of extracting the oil closely resembled that followed by the N'tlakápamuQ, which I described in detail in my report on those tribes. They also dried and powdered the flesh of the salmon after the oil had been extracted, storing this also for winter use.

\section{HOUSEHOLD UteNSILS.}

In the matter of domestic utensils, I did not learn that these differed in any essential features from those in use among the neighbouring divisions, which $\mathrm{I}$ have deseribed before. They had the usual assortment of eedar and other basketry, and bowls and spoons of maple, cedar and horn. They served their food on mats and platters, and in large communistic bowls.

\section{DRESS.}

The old-time clothing of the Stlatlumir resembled that of their neighbours, the upper tribes using garments similar to those of the Thompsons, and the lower tribes sinilar to those of the Halkōmélem. A blanket was the ordinary and only covering for males, and this was often dispensed with. Women commonly wore shirts or slurouds of dressed hide, or petticoats of woven slówē (inner bark of the 
cedas [thuya gigantea] beaten fine). The upper tribes who lived within the "dry belt" possessed, aud commonly wore, moccasins. The lower tribes went barefoot, such foot-gear being unsuited to their wet climate.

\section{Puberty Customs.}

The puberty customs of the Salish differed almost from tribe to tribe. The Stlatlumil customs seem in many features to be peculiar to themselves, and the period of seclusion differed even in the upper and lower divisions, the former being much longer than the latter; the one approximating in this respect to the Thompsons and the other to the Halkōmélem. This is probably due to the differences in the climate of the two groups.

When a girl reaches puberty - that is, at the appearance of her first catamenial flux-her mother takes her out and builds her a small lodge or temporary shelter. In the interior of this a hole is dug several feet deep, the usual depth being the level of the girl's breasts. In this the girl squats while her flux passes. She occupies this structure for at least four days, generally for a longer period, such as eight, twelve or twenty days, or even a whole month, and sometimes as long as six months. For the first four days the girl practically fasts, and thronghout the whole period of her seclusion abstains from fresh meats of any kind. There was a two-fold object in this abstention. First, the girl, it was thought, would be harmed by the fresh meat in her peculiar condition; and second, the game animals would take offence if she partook of their meat in these circumstances. Should a pubescent girl eat fresh meat, it was believed her father's luck as a hunter would be spoiled thereafter. The animals would not permit him to kill them; for it was held that no animal could be killed against its own wish or will. Indeed the Indian looked upou all his food, animal and vegetable, as gifts voluntarily bestowed upon him by the "spirit" of the animal or vegetable, and rewarded himself as absolutely dependent upon their goodwill for his daily sustenance. Hence his many curious customs and observances to propitiate the "spirits" and secure their favour and regard. All his food taboos are conceived and carried out with this intention.

During the whole period of her seclusion the girl busied herself in various ways-by spinning yarn or picking off the needles from fir branches, and by frequent baths and scrubbings and walks in the forest, where she was supposed to hold converse with the "spirits" of the trees, in particular that of the red-fir, whose branches were a sovereign remedy against sickness and "bad medicine" of all kinds.

When the period of her seclusion was over she had to be formally purified by a Shaman; in other words, her "bad medicine" had to be taken from her. This was done by the Shaman marking in red paint the symbol of his snam or "familiar spirit" upon her blanket or face.

In my description of the puberty customs of the StsEélis, I pointed out that the women of that tribe employed certain euphemistic terms to indicate their 
periodic condition. The same practiee is found among the Stlatlumf women. The first menstrual period is called "tloggamug." The word has reference to the hole in the ground beneatl the menstrual lodge. The second is called "t-lokaúcim," puttin! the knees together ; and all after periods, "älitska," going outside, which refers, of course, to their seclusion in the menstrual lodge, it being eustomary for a woman to seclude herself for four days at these periods. This latter term is a modified form of the regular word for "outside." In some villages the term "zómet," abstaining from fresh meat, takes the plaee of "älitska."

Boys underwent a different kind of seclusion npon reaching puberty. Among the upper tribes a youth retired to the woods or mountains and sought his sncm or sulia, every man possessing sueh among these tribes as among the Thompsons.

Among the lower Stlatlum only those youths who had a desire to excel in any particular thing underwent the regular kwäzânteūt, the ordinary youth possessing no personal totem. 'In this respect they followed the custom of some of their Halkōmếlem neighbours.

\section{Mortuary Custons.}

The burial customs of the Salish, like their puberty and other customs, differed from tribe to tribe. There are several peculiar features among the Stlatlumr. When a person died, the corpse was lianded over to the wutltzêtca, or. funerary shaman, who washed and prepared it for burial. This individual was regarded as immune to the "bad medieine" of dead bodies by reason of his mystery powers. The body was customarily washed all over, the hair combed ancl tied baek, the face painted, and the head sprinkled with the down of bull-rushlics, which was potent in checking the evil influences attending eorpses. The lower limbs of the corpse were then doubled up and the knees brought up to the ehin, and the whole body eovered and tied up in a blanket. If the eorpse was that of a woman, it was prepared for interment by a female shaman.

When the corpse is ready for burial, a long pole is run through the binding cords, the ends are raised on the shoulders of two or more elderly persons, and the body is thus carried to the burial grounds. The friends and relations of the dead person follow the corpse to the grave, the proeession being always headed by the shaman in eharge. When they arrive at the grave-yard, a hole is dug in the ground, the Stlatlumf proper praetising inhumation in the disposal of their dead. The hole or grave is then carefully and ceremoniously brushed out by the presiding shaman with branches of the mystic red-fir. This aet eonstitutes a veritable eonsecration of the grave, and drives off all evil influences. The body is then lowered into the hole and covered up with soil, a large stone being placed at each end of the grave to mark the site.

After the inhumation of the body, the burial party returns to the house of the nearest relative of the deceased person, and the women and girls of the household are then instructed to prepare the mortuary feast, and the boys are bidden to go and gather frewood. Invitations to the feast are also sent out. 
In making these, preferenee is given to widows, widowers, and orphans, or to those who are mourning the loss of some dead relative. When the guests have assembled and the food is ready, the men are first fed, being waited upon by the women, who afterwards partake of what the men leave. At the close of the feast, the elder of the household opens the family treasure chests and distributes therefrom blankets and skins to those who have actively assisted in the mortuary ceremonies.

The next four days are spent by the members of the household of the deeeased person in fasting, lamenting and ceremonial ablutions. At daybreak on the fifth morning they all go outside and have their hair cut by the mortuary shaman. He always cuts that on the right side of the head first, the "right" side leing the more honourable in all things in Stlatlumr opinion. When the ceremony of hair-eutting has been performed, they return to the house and paint thcir faces and oil and tie up their hair, put on a more cheerful countenance, and, if the family or household be well-to-do, indulge in a second feast.

This cutting of the hair of the surviving relatives of the deccased persons signifies that the family is "in mourning." "The severed hair among the Stlatlumir was always gathered up and tied into a little ball and taken into the forest and fastened to the branches of a red-fir tree on its eastern side.

\section{Mortcary Taboos and Promibitions.}

There are various taboos and prohibitions in conneetion with the dead. The name of the dead person must not be uttered. This is not so much out of regard to the feelings of the surviving relatives, as on account of the mystic connection which is supposed to exist between names and their owners. To utter or use the name of a dead person is to affect and disturb his ghost or spirit, and draw it back to its earthy haunts. This is inimical both to the ghost itself and to the person using the name, and thus attracting the ghostly influence. It is, therefore, a thing to be avoided. Henee the taboo. 'lime is necessary to remove this danger. After a person has been dead a year or more his name can again be used.

Widows, widowers, and orphans, had certain restrictions placed upon them in the matter of food. In the ease of the widow, she might eat no fresh food for a whole yeur. The other members of the deceased person's family abstained from fresh food for a period of from four days to as many months. The widow might not sleep on the customary bed or sleeping-mats; she must make a special bed for herself of red-fir branches, and also wear a ljead-wreath or "nEmōk" of the same material for a certain period of time. She also wore bands or thongs of buck-skin round her neck, wrists, and ankles. These were put on at the time of the hair-cutting. The objeet of the former was to prevent coughs and other lung troubles, and of the latter, to keep off rheumatism.

1 It is noteworthy and curious that no two of any of the tribes which $I$ have had thus far under study, followed the same custom with regard to the disposal of their severed hair. 
In the ease of the widower, he likewise abstained from fresh meats for some time. The period of abstention varied somewhat with the age of the person-the younger the man, the longer his abstention. Elderly people might shorten the period eonsiderably, and might eat fresh salmon as soon as the first of the salmon "run" was over, and the fish had arrived in numbers, when there was no danger" of their being driven away. ${ }^{1}$

A young wiclower must also be careful to refrain from sexual intercourse fol a year, the more particularly if he possessed esoteric or mystery powers. It was not unusual for a young widower to go apart into the forest by himself for a yenr after the cleath of his wife, and purify himself from the death defilement, and seck mystery powers. To effect these oljects, he would build himself a "'nk·úlzitten" or sweat-honse, or a "'nteEplékeeten" or hot bath, by the side of a stream, and drive the "bad medicine" of his dead wife out of his body by repeated sweatings or" hot baths.

The 'nteEplékecten was thus eonstrueted. A circular hole was dug, several feet deep, and from two to three feet in diameter, at the edge of a stream or lake. This would be lined with branches of the mystic red-fir, and while the water from the stream or lake was pereolating through the sand and filling the hole, the man would be heating stones in a fire close by, and plunging them into the 'nteEpléketen to make the water hot. He would then sit in this hot batl up to his neck for a time, after which he would plunge into the eold waters of the stream or lake. Sometimes he would take a heavy stone in his hand and walk into the water till it rose above his head, and continue thus walking on the Jottom of the lake till want of breath foreed him to clrop the stone and rise to the surfaee. He would continue these praetices day after day, and sometimes by night as well. He would also purge his stomach by enforeed vomitings. This he effeeted by thrusting a "wät-lik:ten" or stomach stick down his gullet.

Young widows had also to undergo eoutinuous eeremonial washings or cleansings. One object of this was to make them long-lived, ancl another, to render them innoeuous to their second husbands. For should a widow marry shortly after the death of her former husband without going through a eourse of ceremonial eleansing, it was believel that her second or subsequent husband's life would be very short.

\section{Birti Customs.}

When a woman was about to give birth to a child, she or her husband, or both together, built a small lodge near by the general dwelling-house. When her labour overtook her, she retired to this lodge, in company with four elderly women, who aeted as her midwives. After the ehild was born, it was customary for the friends of the man and his wife to visit the lying-in-lodge and see the baby, ant the husband was always expeeted to make the visitors presents on this oeeasion to mark the event.

\footnotetext{
1 Salmon were supposed to be peouliarly susceptible to the influence of dead bodies.
} 
The mother and child remained in the lodge for at least four days, and if the weather permitted, this period would be extended to eight or twelve, or twenty days, or to some other multiple of four, the Salish mystic number.

\section{Salmon Ceremonies.}

When the "sock-eye" sulmon (Oneorhynchus Nerka) or "lańwa" run commenced, the first salmon canght was brought reverently and ceremoniously upon the arms of the fisherman, who never tonches it with his hands, to the "wā-tcéo@älōe" or seer, the term meaning "he went to see," who always conducts the salmon eeremonies amoug the Stlatlumir. He lays the fish on the ground iipon a layer of fresh red-fir branches. He next seleets one of the elders of the tribe to assist hin. These two now sit down and arrange before them on the gromnd a bundle of short rods. These rods all bear the "mystery" names and marks, and represent the elders, of the tribe. The rods are arranged in the order of the ages of the men they symbolise. The assisting elder now hands the rods in turn to the wa-tcéogitloc, who lays-them on the lateral fin of the salmon on its right side, the lateral fins being regarded as the salmon's hands. He then formally introdnces the rods to the salmon by name, saying te kaietl, So-and-So, desires to welcome you and shake your hand.

When all the elders have thus been vieariously introduced, and the salmon made welcome to the tribe, it is then ceremoniously boiled, and a small portion of its flesh given to each person present. This done, everyone who has taken part in the ceremony presents a salmon to the wã-teéoqälōe. The fish are placed on the ground bcfore him, and as each man lays his salmon down the seer's assistant calls out the tally, saying: "This is So-and-So's salmon." When all have presented. thcir salmon, the fish are straightway cooked, and the first salmon feast of the season is indulged in by the whole tribe, with the exception of those who are debarred for various causes from eating fresh salmon. After the feast is over, they all take part in a joint ceremonial dance, the wā-teceopälöc leading and directing the perfonnance. He also makes formal thanks to QaQals, the tribal demi-god or culture-hero, for bringing the salmon to them, raising his arms aloft and casting his eyes skywards as he does so.

From this time onwards throughout the season, anyone is free to catch as many salmon as he likes; but no one would dream of taking a "laúwa" salmon before this ceremony had been performed. The Stlatlumi regarded the "laúwa" or sock-cye salmon as the chief of salmon, and hold no ceremony in honour of the other four or five species that frequent their waters.

The significance of these ceremonies is easy to perceive when we remember the attitude of the Indians towards nature generally, and reeall their myths relating to the salmon, and their coming to their rivers and streams. Nothing that the Indian of this region eats is regarded by him as mere food and nothing more. Not a single plant, animal or fish, or other object upon which he feeds, is looked upon in this light, or as something he has secured for himself by his own wit and skill. 
He regards it rather as something which has been voluntarily and compassionately placed in his hands by the goodwill and consent of the "spirit" of the object itself, or by the intercession and magic of his culture-heroes; to be retained anc] used by him only upon the fulfilment of certain conditions. These conditions include respect and reverent care in the killing or plucking of the animal or plant and proper treatment of the parts he has no use for, such as the bones, blood, and offal; and the depositing of the same in some stream or lake, so that the object may by that means renew its life and physical form.

The practices in connection with the killing of animals and the gathering of plants and fruits all make this quite clear, and it is only when we bear this attitude of the savage towards nature in mind that we ean hope to rightly understand the motives and purposes of many of his strange customs and beliefs.

\section{TOTEMISM.}

A study of the totemism of the Salish tribes, besides being extremely interesting in itself, throws, I believe, much light upon, and gives us a deep insight into, totemism in general. A conparative study of the totemism of the tribes of this Continent and that of the natives of Australia lias convinced me that we should no longer regard totemism as something peculiarly characteristic of the matrilineal stage of savage society. Indeed the insistence on this point is causing some of the foremost students of savage sociology to call in question the propriety of making all savage races pass by natural evolution through Matriarchy to Patriarchy and the village commune. They are inclined to see in the earlier stages two equally original and independent forms of social oryanisation. Let this be as it may, taking the American evidence on totemism as a whole, it seems to me impossible to doubt that totemism is as mnch a feature of patriarchy, and the village commune, as of matriarchy. It must be understood that I speak of totemism in the "American" sense of the term. I am unable to regard it any longer in any other sense. Totemism to me is primarily and essentially a "religious" phenomenon, the direct result and outcome of the savage's mental attitude towards nature. The social aspects of totemism I regard as something very secondary and incidental, which attained such importance as they possess in savage organisation only on account of their obvious convenience in classifying and distinguishing one kin group from another.

If totemism were primarily and essentially, as some students hold, a social phenomenon originating only in, and properly belonging to, the matrilineal stage of savage society, we ought to find it decaying and falling into desuetude as matriarchy passes into patriarchy and the village commune. But we do not, at least in this country, and apparently not elsewhere. For while the transition from matriarchal to patriarchal organisation has effected certain superficial changes in the social aspects of totemisin, the religious or essential aspects have remainer unchanged and unimpaired throughout, and are as active and far-reaching in their 
inthence in patriarchy and in the village communism of such tribes as the Salish, as in the strictly matrilineal organisation of the Haida or Tlingit. And we find the same thing in Austrilia. The "religious" or "magical" aspects of totemism there are just as strong and pervasive in those tribes that have patrilineal descent as in those having matrilineal descent. This conld not be, I contend, unless the basal eoneept underlying the various phases or aspects of totemism were of the nature I claim it to be, and had its origin in that attitude which the unsophisticated mind everywlere takes towards the mysterious and the awe-inspiring in nature, which affeets the savage as much in his later social stages as in his earlier.

It does not seem to me seientifie to regard what is demonstrably an unstable, and, therefore, a secondary phase of totenism as its essential and primary characteristic, and overlook another co-existing with it, which is clearly more constant, and, therefore a more essential feature, inasmuch as it persists through all the social changes, from matriarchy to patriarehy, and from that, again, to the village commune, which savage society undergoes, and is the only feature of totenism which does so. We find something equally common and equally essential to the totemism of the village Salish, the patrilineal Sioux and the matrilineal Haida. This, obviously, is not its social charaeter, for the three stocks have each a different social organisation ; but it is its religious character ; fur the three hold and share equally a belief in tutelary spirits, whieh belief is seen to lie at the base of, and give life and meaning to, the totemism of Haida, Sionx, and Salish alike.

Ethmological research here has made it elear that totemism, in one form or another, is found among all the native races on this Continent; and it has further revealed the fact that its social aspects vary with the social organisation of the different stocks. Amongst all, the personal or individual totem or tutelary spirit is in evidence in a greater or less degree. It is this prevalence of the personal totem, the nagual, manitou, sulia, sncm, waqube, or whatever it may be locally called, that has led those American students who have made a first-hand study of the subject to regard group totemism as a natural extension of personal totemism. It is found among all the Salish tribes of British Columbia, and I canuot myself entertain tho least cloubt that it is the true basis and origin of their group totemism. For in the tribes of the interior, where group totems are wholly unknown, every individual is said to possess a personal totem: and it is only when we come to these Salish tribes that possess hereditary group totems, which are demonstrably here, at least, a later development of the nagual, that we find the personal totem less common and possessed by certain members of the tribe only. This seems to be the case everywhere. In those tribes where the kin or family totems are common, the personal totem is correspondingly rare. This suggests to my mind that the personal totems have been superseded by the kin or group totems on account of the changes which have taken place in the social organisation of these tribes. For among the tribes possessing lin or group totems we find a soeial system different from that prevailing among those possessing the nagual only. Wherever the group totem is found, we see hereditary eliefs and distinet castes, medicine and 
secret societies, crests and such-like social features, all or most of which have their bases and find their support in the group or paternal totems. A study of the group totems of our coastal tribes makes this very clear. As long as the totem is personal it is invariably regarded by its owner as an ever-ready, active, ghostly helper, to be called upon for help and protection, in all emergencies; but when it becomes by inheritance a group or kin totem, we find it losing its active tutelary charaeter and degenerating into what is little more than a mere crest or symbol of kinship.

The personal totem or nagual is thus obviously the earlier in time. This among the Salish is invariably acquired in dreams and visions, and the group totems of these tribes have without doubt a similar origin although their acquisition is commonly otherwise accounted for by the Indians themselves. Among certain of the tribes, I find the group totem is not uncommonly regarded as the semi-human, semi-bestial ancestor of the group who lived in the days of the "S"p'tákwetl," the Alcheringa of the Salish. It is noteworthy, I think, that we should find the gronp or kin totems of tribes organised on the village commune basis originating (according to tho tribal myths) in the same way is the group or kin totems of tribes having matriarchal organisation are helieved to have originated; and unless it can be proved that the former have borrowed the idea from the latter-and in the case of the Salish I am doubtful if it can be so proved-then, as this seems an almost universal way of accounting for the group totem, a common explanation should underlie this common belief. I shal! presently offer what appears to me the true explanation of this prevalent belief among savage peoples, and show, from their known attitude towards nature, how inevitably they are led to hold such a view.

As I have stated, dreams and visions are the invariable source of the personal totem of the Salish ; for even when a totem is transmitted from one to another, as it sometimes is, the totem appears to the person or persons upon whom it has been bestowed in a dream or vision, acknowledging the bond and promising protection. The dream or vision is the proper and common mode of communication between the guardian spirit and its protégé.

The manner of personally acquiring a totem among the Salish appears to be the same everywhere. The seeker, who is generally a youth, but sometimes a man of mature years, who has the attainment of some special olject in view, goes apart by himself into the forest or mountains and undergoes a more or less lengthy course of "training" and self-discipline. This course among the Halkōméleu

I If the "moiety," "class," and "sub-class" terms of Australian savage society are of totemic origin, as Mr. Andrew Lang contends, and as seems probable on the analogy of the names of our American "moieties" or "divisions," they would appear to have wholly lost their" original significance, according to Messrs. Spencer and Gillen, and would thus be a case in point in my argument, that the farther we get away from the personal character of the totem the legs religiously significant it becomes, and the more purely social. I contend, therefore, that a study of totemism from the social point of view will uever reveal to us its origin and true import. 
tribes is ealled "Kwākwaiy'sets," among the Stlatlumh, "Kwãzänteūt," and by other terms in other divisions, and continues for a period of from four days to as many years accorling to the object the neophyte has in view. Those taking the longer eourse are generally men seeking shamanistic $0 r^{\circ}$ some other special mystery powers. Prolonged fasts, bathings, forced vomitings and other exhausting lodily exercises are the means adopted for inducing the mystie dreams and visions. With the body in the enervated condition which must necessarily follow such treatment, the mind beeomes abnormally active and expectant; and Ireams, visions and hallueinations are as natural to the novice in such a state as lireathing; and we can readily understand how real to him must seem the vision of the looked-for spirit, and how firm his belief in its actual manifestation.

The psychical offeet of this belief upon some temperaments must be very great, for it enables them to undertake and aceomplish feats of abnormal strength, agility and enduranee; and gives them at times, besides a general exaltation of the senses, undoubted elairvoyant and other supernormal mental and bodily powers. No one, I believe, is less a conseious humbug than the average Indian "Doctor," though it has been eommon to regard him as sueh. His belief in the efficacy of his own mractices and in the power of his nagual to effect the eures he undertakes, is as sincere as the belief of his more sophisticated brother in his trained professional skill and in lis powerful drugs. "Captain Paul," my chief informant and assistant among the Stlatlumin, gave me the following information with regard to the aequisition of one of his own personal totems, or snam as the tutelary is called in this division. He possessed several snam some acquired by direct personal effort, others by transmission from one of his uneles, who was a noted Shaman :-

"One day, when I was a young man," he said, " "undergoing my 'Kwāzânteūt,' secking superior hunting powers, I had a vision in my waking state. A being in the form of a man eame to me with hands outstretehed, holding in the one a human heart, in the other an animal's heart. He bade me take them and eat them, saying it was the food he ate. I raised my hauds to grasp them, but the human heart disappeared, and I seized only the animal heart, which I devoured. The spirit now gave me two leaden bullets, and told me to aim always at the hearts of all the game that I fired at. When he had given me these instruetions he disappeared and where he had stood a moment before I saw now only my rifle. By this I knew that the spirit of the rifle was my snam. From that time onwarl, whenever I shot at an animal I aimed at its heart, which always appeared to my sight many times larger than it really was, so that I had no diffieulty in litting it. I could also follow with my raked sight the path of my own or other people's bullets through the air. I often stood behind my father or my brother when they shot, and told them the direction their bullets had taken, where they would strike, and whether they would bring down their game or not." I was unable to verify the truth of these statements by independent testimony, as his father was

1 I have not written the statement in the exact language he used, but have been careful to give the th'ne sense of his words; his knowledge of English making this very easy. 
dead, and his brother, though still alive, was speechless from paralysis; but I may say I made inquiries as to my informant's skill in shooting, and found that in his earlier years he was a noted shot. Indeed, one of his many names referred to his skill in this direction, " $\overline{\mathbf{A}}$-ZâqEn," meaning good marksman. It was his belief that if the snam had not withheld the human heart from him, and he had eaten it as well as the other, he would have been a great warrior, and could have shot his enemies through the heart as easily as he shot his game.

Touching this and other abnormal powers he formerly possessed, he said the reason that he no longer possessed them was partly beeause he had given up "exereising" himself since his conversion to Christianity, but more particularly beeause his present wife, who had been the widow of another man, hal been careless about carrying out the purificatory ceremonies after the lecease of her former husband, who had been a white man. She had also married him within a few months of her first husband's death. This, which is contrary to the mortuary regulations, and her "bad medicine" consequent upon her non-purification from the death defilement, robbed him of his mystery powers.

This statement concerning the lcss of his snam powers is thoroughly in keeping with the practiees and beliefs of the Indians, and was told me with the naïve sincerity of a child. Though "Captain Paul" has outwardly long given up the practices of his forefathers, and is one of the chief catechists of his Church, his belief in snam powers is at bottom as firm and real as ever it was. A littlo inciclent he related to me regarding the source or origin of the name of one of his grandehildren makes this very clear. When the child was abont a year old and they were thinking of giving it one of the ancestral names, he had a dream or vision, in which a being in human form stood before him and told him to give the name "Skạcénak" to his grandchild. This being was the spirit of the rorld, which, though ancient, yet never grows old and decays, and the name was his seeret or mystery name, the bestowal of which upon the child would make her partake of the immortal character of the world, and in the estimation of her grandparents, prevent her from growing old and decrepit. Needless to say, the name was duly bestowed upon her, in spite of the fact that she possessed already a baptismal name; though few, if any, ontsicle the immediate family eirele, besides myself, know of it or its origin and signifieance. It was not till "Captain Paul " and I had spent several weeks in each other's company, and I had won his confidence and esteem, and he had bestowed upon me one of his ancestral mystery names, thereby relating me to himself, that he gave me the above, and other "esoteric" information, concerning the abnormal sight powers he claimed to have formerly possessed. I do not, for my own part, doubt his possession of them for a moment; the known phenomena of hypnotism make them quite possible, and fully justify one in holding such a belief. That some of the old Indians hacl power to exalt their senses and faculties by invocation of their snam is quite clear, I think, from the feats they frequently attempted and accomplished. For example, Paul's father was a noted mountain-goat liunter. Besides his bow and arrows, with which he 
usually brought down the game, he also earried with him a long, stont elimbingstock, called in the native tongue tleákiiten. This was a plain pole, twenty-four feet long, which was employed in assisting him up and down the faee of the steep and bare clifis, which are the favourite haunts of the wild goat. Upon its upper end a figure or symbol of one of his snam was carved. Paul said that when his father, who was a fanous elimber, came to the face of a precipitous cliff up which it was impossible to climb in the ordinary manner, he would address or invoke this figure, which had the form of a bird, asking it for help and power to ascend the cliff before him. 'Therempon, Jaul affirmed, a living lird of the speeies of the symbol on the elimbing-stock would be seen to fly around his father's head and settle upon the top of the stock. His father, now sure of his snam's aid, would then set the foot of his climbing-pole three or four feet from the base of the eliff, grasp it firmly in both hands one above the other, throw out his feet against the cliff, and thus walk up its face by hauhing himself up hand over hand on the pole. When he reached the top the bird would disappear again.

To thus elimb the straight or overhanging face of a cliff anywhere from twelve to twenty feet in height, with the base of one's elimbing-pole standing on the bare, hard rock, was no easy task, as one may easily see, and there ean be no doubt that the success of the elimber was largely due to his confidence in the help and support of his snam, and the eonsequent exaltation of his faeulties.

Getting down the fase of a cliff was accomplished in the following manner: The elimbing-stock was first let down and held in an upright position, then the hunter skilfully slid down the pole without letting it sway out of the perpondienlar. This does not appear to be so difficult as climbing up.

Among the upper tribes of the Stlatlumu, everyone, as among the Thompsons and other interior tribes, acquired or possessed a snam or personal totem; but amolng the lower tribes the personal totem had largely given way to the family or kin totem, and only those who desired to excel in some pursuit acquired and possessed snam. I shall deal with the reasons of this presently, when I come to speak of the origin of names and their relation to totemism. I desire first to treat of the snam, which are indireetly acquired by transmission from one person to another. We have never before been told how this was done. The gift or transmission, I learnt from "Captain Panl," can only be made or effected by certain persons, such as Shamans, or those who possess great mystery power. One of Paul's maternal uncles was a person of this character. When Paul was a youth this unele wished to make a disciple of him and initiate him into the "mysteries." To this end he eonferred upon him one of his own snam. The transmission was made thus: The uncle took the symbol of his snam, which in this case was a dried bird's skin, and bade his nephew breathe upon it. He then blew upon it also himself, uttered some "zūwén" or mystic words and the dried skin seemed to Paul to become a living bird, which flew about them a moment or two and then finally lisappeared. Iaul was then instructed by his uncle to procure that day a lird's skin of the same kind as his lincle's and wear it on his person. This he did, and 
the following night he had a dream, in which the sncm appeared to him in the shape of a human being, diselosed to him its mystie name by which it might be summoned, and promised him protection and mystic power. The essential feature of this transmission of the snam was the blowing or breathing upon it. Without this, aceorling to Paul, no transuission eould take place. There is mystery power in the breath of a person. It is the manifestation of the spirit within him, and partakes of its nature. A person's breath conveys both good and evil influences. For example, a man seeking mystery power should never permit the hreath of a woman to pass upon him or enter his lungs; it would nullify all his efforts, and effectually prevent the acquisition of the powers he sought if he did so. The verb "to revive" among the Stlathmu shows how elosely and intimately the breath and life or spirit of a person was connected in thejp eyes. The term is "'nperalóeEm," and means in English " to sigh or breathe ine the spirit, and opren the eyes."

This method of acquisition of the totems while it makes perfectly clear the possibility of transmission of personal totems, and shows us that there is nothing inherent in the nature of such to prevent their heing passed on from one individual to another, does not seem to suggest that this was the way in which the kin or group totems originated-at any rate, among these tribes--and we must eonsequently look in some other direction for the cvidence on this head. This evidence will, I. think, be found in the name systems of these tribes. This suljeet is so inportant in its bearing upon totemism, as well as being deeply significant in itself, that it ealls for treatment under a speeial heading. This I have ventured to term nomenology.

\section{Nonevology.}

In my paper on the "Origin and Import of 'Totemism "I I took oceasion to point ont what my studies had led me to believe was the true somrce of totem group llames. My investigations amoug the Salish during the past two years have confirmed me in this belief; and the evidence I have been able to gather on this head, taken in eonjunction with that presented by Messi's. Spencer and Gillen from the Australian field, goes far, I think, to establish the view that in the name systems of savage raees we find the true source of totem group-names. It is certainly noteworthy and significant that two races so widely separated and so dissimilar as the natives of Australia and those of this Continent should have so many points in common in their system of naming. Both have hereditary "secret" or" "mystery" names, which always refer to some event in the lives of the ancestors of the groups or families, or to the supposed origin of the fonnders of these.

Among the Stlatlumir proper, and, according to all my informants, anong all the interior Salish tribes, names were derived from two sources, "tel snam" and "tel stizz"; that is "from guardian spirits" and "from niek-names." The lattel"

ITrans. R.S. Canadu, 2nd Series, vol, ix, sect. ii, 1903. 
were comparatively rare, the main source being the swam. The same person might possess a name, or even several, derived from both sources. One curious fact about the staz names is that they were hereditary. I eall attention to this fact, beeause it shows us in an mmmistakable manner that words or terms which have once been nsed as names are invested thereby in the unsophisticated mind with a special chancter and significance. They partake in a nysterious way of the nature of those who first bore them. I cannot say to what extent stāz names were employed apart from their original signification. They would appear to be generally given to those who resembled in some way the person who originally bore the name. One of Paul's names, he informed me, was a stäz name given him by lis maternal grandmother. The name had been first borne by a son of hers, whom Paul seemed to reeall to her. This son was a famous shot with the bow and arrow, and the name signified "good marksman."

As a rule, stāz names were deseriptive of some characteristic of the person bearing it, either mental or bodily, and generally the latter : such as "'ntlótealūe" = squint-eye, "'nkwáláloe" = staring-eye, or the plural form, "nkwelkwálālōe" = staring-eyes.

Another curions fact about these stã nanes is that they are never given to women. A woman's name is always an hereditary, family, or a self-acquired snam name, or both. She is never known by a nick-name.

All the hereditary names among these tribes are said to be either snam or stāz names. Each family possessed sits own list or stock of names. Those belonging to, or which had been borne by, distinguished individuals of the family were the names most commonly used. They might be drawn from either the mother's or the father's side of the house. A large proportion of these names are animal or plant names; others are taken from inanimate objeets or from natural phenomena.

Among the lower Stlatlumu, Halkōmélem and Coastal tribes, names wero derived from many sources. These, aceording to Paul, might be any or all of the following: "tel s'úlia," from the dream spirit; "tel ckókwa," from grandmothers ; " tel smétla," from lleam danees; " tel zūwên," from mystery men; " tel Qals," from Qals; "tel s'p"tiikwetl," from nystic beings; "tel stãz," from niek-names; "tel Siam," from the "pollutch"; " tel ewolíam," from Shamans; and from several other solurees.

These family or hereditary nantes among all the tribes, but especially among the Delta and Coastal divisions, were regarded as among the most sacred possession of the kin-group and were most jealously guarded. Men who, like Paul, were related by consangnineal or affinitive ties in different villages or groups, had distinet names in each.

Among the interior tribes, where the group-crest or totem was apparently unknown, there do not appear to have been any group names; but when we reich the lower Stlatlumy, the Halkōmélem and Coastal tribes, where the personal totem or snam has largely given place to the group totem, the kin-name, or what is the same thing, the kin-crest, is everywhere common. 
Whatever may have been the cause or causes which led to the partial decay of the personal totem and to the development of the kin-totem among these tribes, $I$ think no one who takes all the evidence into eonsideration can doubt that among the Salish, at least, the personal name and totem gave rise to the group or kin name and totem.

Thronghout all the Salish tribes the local or village gronp, as a whole, invariably bore a topographical name, but among the lower tribes, the subdivision of the village group, the constitnent kin-groups or families, are distingnished from one another by different crests and crest names. These crests and uames are totemic in origin and significance, and are almost invariably derived from the early ancestors of the family or group, commonly from the "First wan" or "Founder" of the family. Among certain groups these "First men" are always conceived as "tel swéyil," Teaven born; others, again, are "tel temóq," eavth bor". These resemble the ertwa of the Kaitish and Unmatjera, and are always regarded as "real men." Paul's kindred at Yale claim descent from these, and their totem symbols or crest is a human tigure. Piul remarked in this connection, "If I were to dic here (Port Donglas), and my people were to hury me in the oldfashioned way, they would paint or carve a figure of a man on my coffin as well as ny other crests. Anybody seeing this wonld know that I belongerl to Yale on one side of my family."

Yet other family groups are thought to be descended from the mythic semihuman, semi-bestial beings of the S'p'tákwetl days. But from whatever source their traditions make them spring, we always find their names are hereditary and relate to incidents in the lives of the fathers or early members of the group.

Now, as most of these incidents are clcarly mythical in character, they cannot be the true source of the names, and must have been created to account for the names themselves. Whence, then, came these family hereditary toten names?

We have seen that the source of a large proportion of the personal names was the snam or nagual; we have also seen that these personal names are liereditary, and descend from father to son, or from generation to generation. May we not, then, reasonably conclude that the hereditary kill-name had a similar sonrce, and was the personal snam name of some distinguished ancestor of the kin-group? Holding the views that the Salish did-views which appear to be common to unsophisticated races everywhere-that the beings which peopled the earth in the "days of the new," partook of the character and shape of both man and beast, it would be strange if in their endeavours to aecount for some of their hereditary names their innaginations did not suggest relationship to and descent from these beings. To their minds there was nothing impossible or even incongrnous in such a relation, as their myths, which I have recorded, plainly show. And if this be true, as I hold,

I It is not without point and interest to remark here that we find many of the local totem groups of the matrilineal Haida bearing topographical rather than totem names, though they possess the latter as well as distinguishing group-crests. 
of the Salish, then it may very well be true of all other nusophistieated peoples which hold similar animistie beliefs.

I have said that a eertain sept or kin-group, to which Paul belonged on his father's side, traced their descent from the "ertwa men " of the S'ptifikweti days, and owned a 'nteinwilap or erest in the form of a human figure. But besides this group there was ancther witl whieh he was associated by aftinitive ties at Yale which traced its descent from the mountain-goat, and whose crest or kindred sy'nbol was the figure of this animal. The traditional origin of this group is given in a very interesting and instruetive myth whieh $I$ have given in full below.

According to this myth, the founder of this totem-grouly was not a "First man." He was a youthful hunter, who lived with his parents in a village with other fanilies. He was accustomed to hunt the wild goat; and it seems that both he and the rest of his tribe had been careless in their treatment of the earcases of their game. The chief of the goats therefore planned to draw him to their eamp and reveal to him their mystery powers and teach him the proper way to treat the "animals" which he killed. These goats were like the S'p'tákwetl beings; they had a human as well as a bestial side. He stayed with them and learnt many things; assumed the form of a goat; took two of their women for wives; had children by them; aud was later sent home again with his two sons, who became the founlers of the mountain-goat kin.

Thus the story las it; but the faets of the ease are most probably that a certain young man went off to undergo his puberty training and had a dream or vision of the mountain goat, whieh he regarded as his snam. He may have dreamt the incidents of the story, which are thoroughly in keejing with Indian eonceptions, or they may have beeone associated with the kin-totem in some other way.

The value of the myth to $u s$ is in its revelation of the workings of the primitive mind, and of the way in which it looked upon nature. Viewed in this way, the myth will often offer to us valuable light and suggestion as to the real origin of what it purports to explain.

The fanily hereditary names of the group, whom tradition derives from the "ertwa men." all relate to the "mystery powels" of the "First man," or to a magie eontest he had with the demi-god Qals. It is recorded that when Qals was travelling down the Fraser he stopped at Yale to try his mystery power upon l'aul's paternal ancestor, whose name was Qaílqilmos, which means "great in Iuystery power," having muel the same signifieation as the term "Qals" itself. The contest between the two was very severe, and Qailqilmos was the victor. The trial between them seems to have eonsisted in taking away each other's strength and vignur. When Qals pereeived that he was beaten, he told his adversary to take a measuring stiek (sqélkintEn) and neasure all the different parts of his body.

Qaílqilmos dirl this. Qals then said, "O my grandfather," yon are very strong; now make me strong again." Qaílqilmos restores him to strength and vigour

Note the form of address. 
again, and as they parted Qals bade him thereafter call his children by the names of the different measurements he had taken of his body.

One of Paul's names, viz.: "soélemken" = head measure, is a specimen of these names. Other names of this family are "slấtetel," "slätcētluk," "släteElût." These are also called "tel Qals" or "Qals' names." They signify "power to transform." The first was borne by Paul, the seeond by his brother, and the third, which has the feminine suffix, by his sister.

Paul had kindred at Stseélis, at Lilūetól, and at several other villages. In each of these he had one or more names peculiar to the group or kin to which he was affiliated. One of his Stséllis names was "tel züwên." This was a "mystery" name, and was supposed to earry with it power over the salmon. The term was "Swätlílsulten." Züwén names always went in pairs, that is possessed a mascnline and a feminine form. The feminine form of this was "Swätlalsulwet."

Another pair of these names was "Skwiláqúlanoq" (masc.) and "Skwiláqtelât" (fem.) The names of two of the "first pairs" of the Skaúlits, which I gave in my notes on that tribe last year, are also Zūwén names, Paul said. Another specimen of these, which belonged to some of the Const Salish, is "Skwélesilten" and "Skwélesât." These are derived from the word "copper," lix Eétis, and evidently commemorate the acquisition of some "copper treasure."

Paul's most honourable name at his mother's village of Lilūetól was "NErêpekEnâlct," which signifies " to grow or become great." This also was a Zūwén name.

It is difficult to ascertain with any exactitude who or what these Zūwen people were. They were supposer to possess certain mystery or magic powers. They used esoterie formulas or incantations in their ceremonies or performances, the knowledge of which was most jcalously guarded, and only spoken of in whispers. When a Zūwén person desired to initiate his son or nephew he took him apart by himself, gave him a Zūwén name, generally his own, and revealed to him in whispers his saered knowledge eoncerning the origin of his family, and imparted to him the word or words of power.

The Zūwên do not appear to have been a brotherhood or society. They are supposed to be the lineal descendants of those who traced their origin to the mythic beings of the S'p'takikwtl times, for they are thought to have power, by means of certain secret ceremonies and mystic words, to summon or compel the presence of the animals which are the modern representatives of their mythic ancestors.

For instance, the eldermen of the mountain-goat people of Yale and of the Sturgeon people of Skaulits could go to the mountains or to the river, as the case may be, and by a mystic dance, by spitting and breathing on their hands and wrists and rubbing them in a peculiar way, and by the utterance of the "worls of power," cause their "relatives" to come and be killed for food. According to Paul, who is related to the Sturgeon people, the elders of this kin-group met together at night and invoked the sturgeon in the mystie tongue in such words as these: " $\mathrm{O}$, our grandfather (or grandmother), come to your grandchildren and be killed for food." 
Shortly after a sturgeon would be taken. When the fish was killed the carcase was drawn to the shore and secured for the night. Next morning at sunrise it was cut up and distributed, great eare being taken to wash all the blood spilt in the operation back in to the water. The offal was also carefully gathered up and returned to the water, and, after the fish was eaten, all the bones likewise. The reason for this I gave in the Sturgeon myth recorded in my last report; it will also be found in the inyth of the mountain goats herein recorded. The whole ceremony of cutting up was carried out with great decorum and reverence. The fish might be shared among all the tribe, but only those who belong to the Sturgeon crest or kin could assist in the eapture and cutting up of the creature and in the disposal of the blood, offal and bones.

When cutting up the sturgeon the spinal eord ("Kwattlala") is taken out and eut into pieces about six inches long. A piece of this is given to each man assisting in the operation, but no woman or youth must touch it. The men who receive these strips of "Kwaitlala" take them lome and suck them. Later they return them to the elderman or master of the ceremonies, who takes them, and some of the eggs or the head of the sturgeon, and makes a soup from them. Before returning the strips of "Kwätlala" each man puts bis private mark upon his piece, and when the soup is ready he gets it baek again in his portion. His wife may now eat of the "Kwátlala" if she has not lately given birth to a ehild or recently recovered from her catamenial flux.

Similar ceremonies were performed by other "crests" or kin-groups who claim descent from S'p'tî́kwetl animals.

If we take the culture of the Interior Salish as typical of the original Salish, then the Zïwén features are comparatively recent in their growth and appearanct. They are unknown in the interior tribes. We first meet with them annong the lower or mixed Stlatlumir. Below this they form an essential and characteristic part of the sociology of the Halkōmélem and Coast Salish and play an important rûle in the. name systems of these tribes.

I think it well to remark again that names among the Salish tribes, as among other of our native stocks, seem never to have been used in the sense in which we employ them, with the possible exeeption of the stāz or nickname. And even these had a sense and significance in the native mind they never have in ours. It is somewhat difficult, therefore, for the soplisticated student to rightly compreheud what "names" signified to the Indian. Apart from the stāz names, they are never nsed as mere appellations to distinguish one person from another, as among ourselves, nor do they seem to have been used ordinarily as terms of address. They are primarily terms of relation or affiliation, with historic and mystic reference. They were reserved for special and ceremonial occasions. The ordinary terms of address among the Salish tribes, as among other primitive peoples, were those expressive of age. Length of years with them carried with it experience and wislom, and, therefore, honour. It was customary, therefore, for the speaker, when he addressed a person whom he wished 
to honour or placate, to apply to him some term indicative of superior age, and so of superior honour, such as uncle, aunt; father, mother; grandfather, grandmother. Folk-tales and myths are full of such examples of adilress. Terms of address within the family circle are all framed on the same plan. A brother does not eall his brother or his sister by a snam or hereditary or even by a stñz name, but always by a term expressive of their relative ages; and when speaking of them to others he uses terms with similar meanings. A man's "proper" names seem only to have been used among the Salish on eeremonial oceasions, or when one wished specially to gratify or honour a person: Said Paul to me in this connection: "When I was a little boy my mother wonld sometimes speak to me by one of my aneestral names to coax ine into duing something for her, or when I had gratified her by some act." Or again: "If my father or uncle had given somebody something, such as food, or" skins, or blankets, the recipient would invariably, in thanking him, employ one of his 'proper' names."

On oceasions of public eeremony, sueh as the pothatel or other feasts, or at the winter laneing, men were always formally addressed by their hereditary, mystery or snam names. During the Smētlás, among the Halkōmélem tribes, the dancers were always called and aldressed by their Smetta or nagual names, but these were dropped again as soon as the Smêtlấs was over, more particularly if the name itself earried in its ordinary sense any dishonouring reflection with it. Some animals, such as the dog, were held in small esteem by the Salish, and a man, whose sulia was a dog, was not prond of the cireumstance after the Smètlás season was orer. During the dancing he would be spoken of and addressed by his "dor" name, but after it was over it would be deeply offensive, besides being eontrary to etiquette, to address him by this term. When I sought an explanation of this from Paul he replied that a dog was the absolute property of its owner, who might ill-treat it or kill it, or do whatever he liked with it, as with a slave. It had no rights of its own; it lived by sufferance, consequently it was despised and held in small esteem. A person, therefore, having a "dog" sulia or name was not partienlarly proud of it outside of the Smêtlâs (where it had no offensive signification, being then a "mystery" object), and was not desirous of having it applied to him, as it earried with it a suggestion of " $\operatorname{dog}$ " descent,-an origin as ignoble and contemptible in Indian eyes as in those of more sophisticated races.

On the other hand, some of the Smettlats names were of honourable import, and conferred distinetion npon their owners. A person possessing sueh a name would feel gratified at having it applied to him at any time.

In the Smêtlás of the StsEếlis the elderman of the mountain-goat lin always daneed the "Goat" dance, whieh was ehancterised by his wearing a goat-skin with the hair upon it. This he would from time to time turu about, at one time with the hair inside, at another the opposite. This aetion portrayed the dual nature and the transformation of his goat ancestors. The dancer and the dance both bore the name Tlipelkélem, which signifies "tuming the hair insicle," that is, "becoming a man."

Aceording to Paul, among the Halkōmélem no man of position or rank or 
Shortly after a sturgeon would be taken. When the fish was killed the carease wils drawn to the shore and secured for the night. Next morning at sunrise it was cnt up and distributed, great care being taken to wash all the blood spilt in the operation baek into the water. The offal was also carefnlly gathered up and returned to the water, and, after the fish was eaten, all the bones likewise. The reason for this I gave in the Sturgeon myth reeorded in my last report; it will also be found in the myth of the momtain goats herein reeorded. The whole eeremony of cutting up was carried ont with great deeorum and reverence. The fish might be shared among all the tribe, but only those who belong to the Sturgeon erest or kin eonld assist in the capture and cutting up of the creature and in the disposal of the blood, offal and bones.

When cutting up the sturgeon the spinal cord ("Kwâtlala ") is taken out and cut into pieees about six inehes long. A piece of this is given to each man assisting in the operation, but no woman or youth must touch it. The men who receive these strips of " $K$ wátlala" take them home and suek them. Later they raturn them to the elderman or master of the eeremonies, who takes them, and some of the eggrs or the head of the sturgeon, and makes a soup from them. Before returning the strips of "Kwâtlala" each man puts his private mark upon his piece, and when the soup is ready he gets it back again in his portion. His wife may now eat of the "Kwátlala" if she has not lately given birth to a child or reently recovered from her eatamenial flux.

Similar eeremonies were performed by other "crests" or kin-groups who claim descent from S'p'tíkwetl animals.

If we take the eulture of the Interior Salish as typical of the original Salish, then the Züwên features are comparatively reent in their growth and appearance. They are unknown in the interior tribes. We first meet with them among the lower or mixed Stlatlumi. Below this they form an essential and eharaeteristic part of the sociology of the Halkömélem and Coast Salish and play an inportant róle in the name systems of these tribes.

I think it well to remark again that names among the Salish tribes, as among other of our native stocks, seem never to have been used in the sense in which we employ them, with the possible exeeption of the stiz or nickname. And even these had a sense and signifieanee in the native mind they never have in ours. It is somewhat difficult, therefore, for the sophistieated student to rightly comprehend what "names" signified to the Indian. Apart from the stiz names, they are never used as mere appellations to distinguish one person from another, as among ourselves, nor do they seem to have been used ordinarily as terms of address. They are primarily terms of relation or affiliation, with historie and mystic reference. They were reserved for special and ceremonial oeeasions. The orlinary terms of audress among the Salish tribes, as among other primitive peoples, were those expressive of age. Length of years with them carriel with it experience and wiston, and, therefore, honour. It was customary, therefore, for the speaker, when he addressed a person whom he wished 
to honour or placate, to apply to him some term indieative of superior age, and so of superior honour, such as uncle, annt; father, mother; grandfather, grandmother. Folk-tales and myths are full of such examples of address. Terms of address within the family circle are all framed on the same plan. A brother does not eall his brother or his sister by a snam or hereditary or even by a stāz name, but always by a term expressive of their relative ages; and when speaking of them to others he uses terms with similar meanings. A mar's "proper" names seem only to have been used among the Salish on eeremonial oecasions, or when one wished specially to gratify. or honour a person: Said Paul to me in this connection: "When I was a little loy my mother would sometimes speak to me by one of my ancestral numes to coax me into duing something for her, or when I had gratified her by some act." Or again: "If my father or uncle had given somebody something, sueh as food, or" skins, or blankets, the recipient wonld invariably, in thankiug him, employ one of his "proper" names."

On oceasions of public ceremony, such as the potlatch or other feasts, or at the winter daneing, men were always formally acklessed by their hereditary, mystery or snam names. During the Sinc̄tlás, anong the Halkōmélein tribes, the dancers were always called and addressel by their Smêtla or nagual names, but these were dropped again as soon as the Smētlás was over, more partienlarly if the name itself carried in its ordinary sense any dishonouring reflectiou with it. Some animals, such as the dog, were held in small esteem by the Salish, and a man, whose sulia was a dog, was not proud of the eireunstanee after the Smetlás season was over. During the dancing he would be spoken of and addressed by his "dor" name, but after it was over it would be deeply offensive, besides being contrary to etiquette, to address him by this term. When I sought an explanation of this from Paul he replied that a dog was the alsolute property of its owner, who might ill-treat it or kill it, or do whatever he liked with it, as with a slave. It had no rights of its own ; it lived by sufferanee, consequently it was despised and held in small esteem. A person, therefore, having a "dog" sulia or name was not partienlarly prond of it outside of the Smettlâs (where it had no offensive signification, being then a "mystery" objeet), and was not desirous of having it applied to him, as it earried with it a suggestion of " $\operatorname{dog}$ " descent,—an origin as ignoble and eontemptible in Iudian eyes as in those of more sophisticated races.

On the other hand, some of the Smètlás names were of honourable import, anr conferred distinetion upon their owners. A person possessing such a name would feel gratified at having it applied to him at any time.

In the Smētlás of the Stseêlis the elderman of the mountain-goat kin always daneed the "Goat" danee, which was characterised by his wearing a goat-skin with the hair upon it. This he wonld from time to time turn about, at one time with the hair inside, at another the opposite. This ation portrayed the dual nature and the transformation of his goat ancestors. The dancer and the dance both bore the name T'lipelkélem, whieh signifies "turning the hair inside," that is, "beeoming a man."

Aceording to P'aul, among the Halkōmélen no man of position or rank or 


\section{$15+$ C. Hill Tout.-Report on the Ethnology of the Stlatlum $\mathrm{H}$ of British Columbia.}

faunily had a "stäz" name. Such names were borne by persons of inferior station only and by slaves. Men of rank always bore hereditary "zūwến" or mystery Inmes indicative of their honourable descent. Among these tribes every family $m$ kin-group of distinetion had its pedigree and names of deseent and kin-crests. All names were known publicly, but their significance and the family traditions relating to them, more particularly those belonging to the "zūwén" elass, were secret and private to the individual or to the kin-groups. Paul said that any other Indian of "family" could tell to what class a man belonged as soon as he heard his name, and whether the term were a "zūwến," or "mētlás" or other name.

One peculiarity about snam names was that the term was invariably more or less modified in form. Among the lower Stlattlumir, for instance, the name of a inan whose snam was the grizzly bear would be "Nklatel-mácket," and that of a woman "Klatlil-mênak." The common term for grizzly-bear was "Stlātlálem." Teit has remarked in this connection that the totem names of the Thompson are modified forms of the common names of the objects from which they are derived. The practice would therefore seem to be a customary one.

\section{Crests.}

Intimately conneeted with names were the personal and family "crests." Indeed, in a certain sense the Salish kin-names may be said to be the result of the erest, the kin or family being known and distinguished by its crest; so that if further evidence be wanting to sustain my elaim, that the kin-name was originally the personal mystery or snam name of one of the ancestors of the kin, it may be found in the study of these crests.

There were two kinds of these, called in the Stlátlumir dialect the " 'ntcñwálap skweékwilanq," or dreen picture belonging to the individual, and the "'nteu wálap tlel (=tel) kólelea" or picture of descent belonging to the family, and the latter is undoubtedly the former become hereditary. And just as there are no hereditary kin-group names among the Interior tribes so are there no kin-group erests.

According to Paul every individual had a snam mark or picture, in other words a personal "crest," the symbol of his nagual. This he customarily placed upon his personal belongings to mark or distinguish them from those of his fellows. But, when we deseend the river and meet the Delta and Coastal tribes, we find the personal "crest," like the personal totem, giving place to the kin-group "crest," which among these tribes is possessed by every family of standing, and is its peculiar distinguishing visual mark.

Whenever a dwelling was erected, the common practice in earlier days was for the eldermen of the kin-groups to earve, or have carved for them, on the main posts of their "apartments" their hereditary nteüwálap kólelca or "crests of origin." Said Paul to me in this comection: "If you had come to my father's house fifty years ago, you would have scen a 'picture' carved on each of the main yosts of the interior', and had you asked him what those 'pictures' meart, he would have answered you with pride: 'nE nteñwálap tlel te' kólelca,' my crests 
of descents." Sometimes these figures were earved on the exterior of the building or erected on poles or placed on the gable encls. They were also invariably painted or earved on the family graveboxes.

Pride of "family" is the distinguishing trait in the character of the Delta and Coastal Salish. However this may have been developed, whether by spontaneous growth or as the result of the conquest and subjugation of an inferior alien race, there cau be no doubt that it has been one of the ehief factors among these tribes in the creation of family traditions, and in the evolution of kin erests and names from-the earlier personal erests and names.

The same desire aud eraving for social distinction led to the rise and development of the "potlateh" and to the so-ealled seeret societies of the tribes of this region.

Tine, or Divisions of the Day.

The Stlatlumir language is rieh in terms or phrases expressive of the "time" or divisions of the day. I have not met with similar divisions in the other dialeets I have examined, though it is possible they may exist. The following list is by no means exhaustive :-

plan teEä́c p'eñl, auroro, or daybreal, ad litt. "just it comes day."

plan aitl p'eil, dawn, ad litt. "just now morning."

plan teEtl púlmĩq, daylight, ad litt. "just see things."

plan aitl eskêt, broaci daylight, acl litt. "just now day."

ótska snúkuma, sumrise, ad litt. "outside sun."

plan kāqÉqEtka, carly morn.

küqấtka (voice dwells on second syllable) midway between sunrise and noon.

ken ripa, noon, middey.

lifn múinulkwa, two hours (approx.) afternoon.

kEn múlekwa, middlle of afternoon.

rápelmin, about four hours after noon.

älac kenmúlekwa three-fourths of the tley gone.

kélekam snúliuma, sun sitting down.

keHíma snúkuma, sunset, ad litt. "gone the sun."

rap, evening.

skaútlenteut, ereeping up the monntain. This refers to the line of shadow on the eastern mountains.

ketclipkwa, reached the top, i.e., the line of shadow.

kEkwÉca, twilight.

ckietlipa, getting elark.

kātlípa, night, darkness.

klipetlpém, piteh dark.

\section{Sundry Beliefs and Superstitions.}

To sneeze three times in succession was believed by the StlatlumH to bring good luck to the person sneezing. To sneeze through the right nostril, nzäalukc, 
was also a sign of good fortunc, but throngh the left nostril, 'ntcēkwiilukc, a sign of bad fortune.

The small red lizarl was much drcaded by the Stlatlumu, who regarded it in much the same light as the Haida did the mousc. They believed that it entered a man through his nostrils and ate up his heart and liver, and thus killed him.

The fullowing story illustrates their superstition on this head. Two men werc out hunting a long distance from home. One of them went off to fish alone, and came to a ccrtain spot where he perceived many of the stones on the beach stained with a peculiar yellow matter. He thought to himself: "This is a "bad place to be in; there must be lots of lizards about here; I had better get away at once." So he hurried off and went back to his comrade, and told him he had by ill luck chancel upon a lizard colony, and that it would be wise for them to leave that neighbourhood as quickly as possible. His companion agreed, and they set off without delay, travelling for the rest of that day and all through the following night, without stopping to rest. When they got home, the man who had visited the lizard "village" told his wife what had happened, bidding her and the children watch at the door while he slept. She rolled him up in a blanket and he slept all that day, while she and the children watched. In the evening he rose and took their place, and sat watching by the door all night. No lizard appeared that night. Next morning he went to bed again, and the family kept watch as beforc. Early that morning the wife had occasion to go down to the river for water, and as she stooped to dip it up, she perceived two lizards hiding under the bottom of the canoe. She straightway killed them and hurricd back to tell her husband that the lizards had followed and found where he was staying. He bade her watch carefully all day that none came near while he slept. The next night he watched again. The night was the most dangerous time, as the lizards then wandered about. About sunset therefore he made a large quantity of brine, and took a large basket and set both by the door and sat down to wait events. As soon as daylight had gone, the lizards began to come forth in twos and threes. They sought to enter the house, but when they came near the doorway, he poured brine over them, which instantly killed them. When dead he placed them in the basket, and by morning he had filled it with dead lizards. They continued to watch and kill the lizards in this way till all had been exterminated, and the man was safe from them again.

This is said to have happened within the last few years. It is clear that the incilcnts arc nodern, because of the use of the "brine" to kill the lizards. The Inclians had no salt and therefore no "brine" before the advent of the whites.

\section{Lixguistic.}

As far as I am aware, no attempt has been made to set forth the grammatical structure and peculiarities of the Stlatlumn speech, which, while approximating in its vocables to the N'tlakipanme on the one side, and to the Halkōmélem on the 
other, is quite distinct in structure from either of these dialects. Some of the peculiarities are very interesting. The more noticeable of these are the verbal termination "En," which is not found in any of the other dialects I have examined; a plural article or demonstrative " $\overline{0}$ " which precedes substantives used in a plural or collective sense, and in certain constructious, is suffixed to verbs as a pronoun of the third person plural; and a final "a" which is invariably added to nouns. and pronouns in composition.

Thus :-

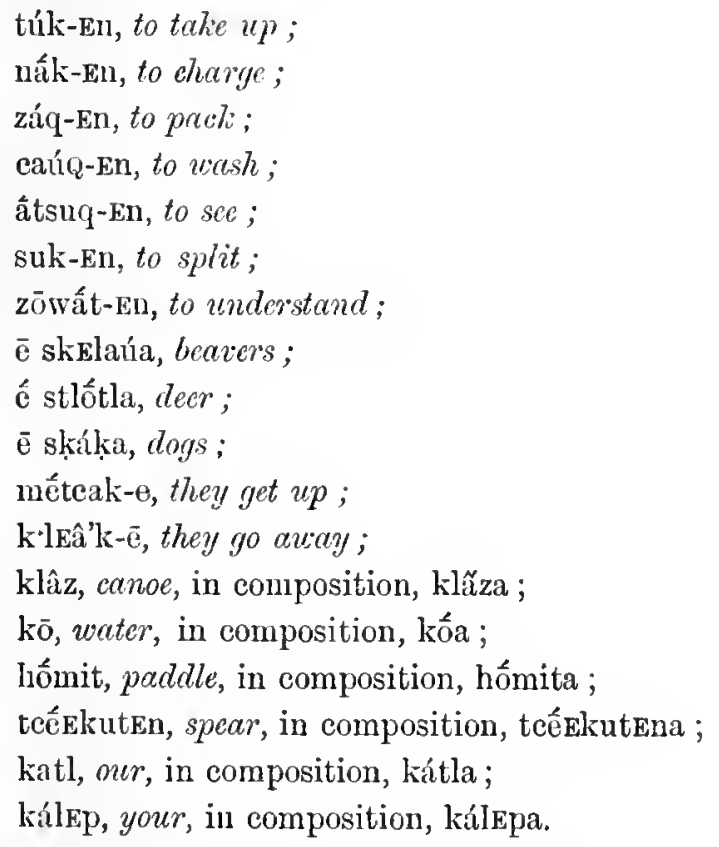

Other examples may be seen in the native text. Other peculiarities not observable in the dialects previously examined are certain incorporative or enclitic particles which have the function of an objective pronoun of the third person; the use of the verbal affix ES or EC (otherwise as or ac) as a prefix to words to give them verb force, and a modification of the same affix under the form "cEc" or "ses" to signify action upon something.

Thus:-

réEp, to grow ;

réeps, he grows ;

rēEpstalĭ, to make him grow up;

nauk, to steal;

nauk-men-ta'ti, steal him away;

nauk-'men-Em-to, he was stolen;

nac, to go ;

nac-mèn-ac, he went to him;

tcéōq; to come ;

tcêō-men-ac, he eame to him ; 
158 C. HuL. TouT.-Report on the Ethnology of the Stlatlum of British Columbia.

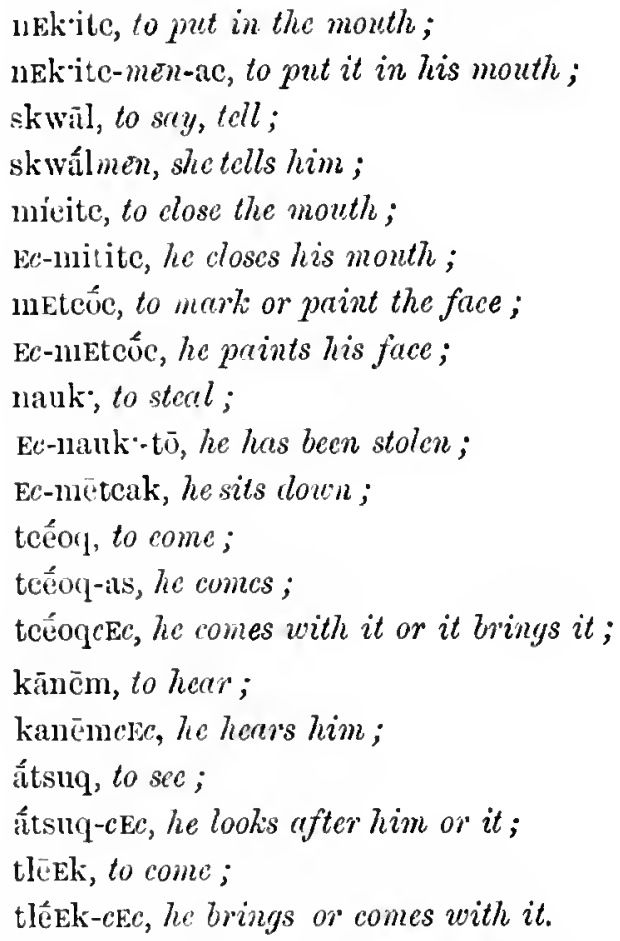

As in the other dialects examined, we find a distinct and separate particle in Stlatlumn to express futurity; no two thus far have been alike.

My grammatical data have all been drawn from the middle StlatlumH, from the LìlúEtól or Lílūet proper. I consider this the purest form of the Stlatlumn speceh. The dialectical differences in the upper and the lower tribe, however, are not great, and belong rather to the vocabulary than to the structure of the language.

The chief interchanges of letters are $c=s h$ for $s$. This was particularly noticeable in the specch of Paul. $L$ and $n$ also commonly interchange. In the mouth of one person the " 1 " sound will predominate, in that of another the "n" sound. The long vowels $\bar{e}, \bar{i}$, and ai are sometimes very difficult to discriminate. The investigator will find himself sometines using one, and sometimes another, in writing the same word. In the texts as here presented, I have made an attempt at uniformity in the use of these vowels. The short vowels are also very indeterminate in character.

\section{PhoNology.}

Vowels.

a as in English hat.

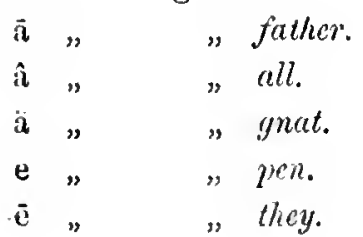

$\mathrm{i}$ as in English pin.

\begin{tabular}{|c|c|c|}
\hline$\overline{\mathbf{1}}$ & $"$ & "pique. \\
\hline 0 & $"$ & $"$ pond. \\
\hline o & $"$ & "tone. \\
\hline $\mathbf{u}$ & $"$ & zut. \\
\hline & ", & , boot. \\
\hline
\end{tabular}


E, obscure vowel as in English flowcr; $u$ written above the line, a vowel somur which mostly follows the palatised $\mathrm{k}$ and is only partially articulated.

\section{Diphthongs.}

ai, as in aisle; au, as in cow; oi, as in boil.

\section{Consonents.}

$\mathrm{b}$ as in English.

$\mathrm{h}$,

k " $"$

$\mathrm{k}$. a strongly palatised or " clicked" $k$.

$\mathrm{k}$ intermediate between our $k$ and $g$.

tl an explosive palatised $l$.

L the same but shorter, approximating to the sound of the final-tle in the word cuttlc.

1 as in Englisl mostly, but interchanging with $n$ in the speech of some Indians.

$m$ as in English.

n as in English, sometimes more strongly nasalised than with us.

$\mathrm{p}$ as in English.

p' no English equivalent, semi-mute semi-sonant.

$r$ the sound this letter stands for is not our $r$, but something midway between it and $l$.

$\mathrm{t}$ as in English mostly, sometimes intermediate between our $d$ and $t$.

t' a palatised or "klicked" $t$, scarcely distinguishable from the "klicked" $k$, but nevertheless a distinct sound.

$w$ as in English.

y $"$ "

$\mathrm{q}$ as in $\mathrm{ch}$ in loch in broad Scotch.

Q approximately as $w$ is uttered in North Britain.

$\mathrm{H}$ as the German in ich.

$c$ as in English sh.

tc, as $c h$ in the word church.

ts, as in English.

$\mathrm{dj}$, as $j$ in English juice.

$\mathrm{kw}$, as $q u$ in the word quantity.

The comma sign, ', written above the line, means a panse or hiatus usually caused by the elision of a vowel. When placed before the letter $n$ thus, 'n, it marks the absence of the initial $e$ sound. This $n$ is a characteristic initial sound of many "proper" names in StlatlumH. The same feature is found in a still more marked degree in the neighbouring N’tlakápamu\&. 


\section{Accent.}

Accent in the StlatlumH follows mnch the same laws as in the other Salish dialects examined. There are two accents, a primary and a secondary one. The former marks the principal radix, and the secondary the quantity of a word. Accent also plays an important róle in oratory and rhetoric.

\section{Number.}

Number is distinguished in Stlatlum, as in the other Salish dialects, in a variety of ways, the commonest of which is peculiar to itself. This is by prefixing the demonstrative particle $\bar{e}$ to the object word and adding to the latter a final $a$, thus : te skelan', a Ecaver ; ē skelau'a, bcavers. This $a$ is also added to words in the singular in composition. It therefore is not characteristic of plurality or severalty, though it is invariably found in company with the number-making particle. Reduplication plays its ordinary rôles in the ideas of severalty or distribution in Stlatlumir.

The vocabularies and texts will afford abundant examples of these.

\section{Gender.}

The formal grammatical gender which I have pointed out in other dialects appears to be wanting in the StlatlumH. The demonstrative particles have the sanse form with masculine as with feminine terms, with one exception. I have drawn attention to this under "Terms of Consanguinity," page 206. When therefore it is necessary to distinguish gender, it is effected by placing the terms for "man" or "woman" before the class word. That for man is somewhat modified. Thus :

my child (masculine), tē skai'wa n'skóza. my chill (feminine), tē yấkutca n'skóza.

The term "old" used substantively is sometimes differentiated to mark gender. Thus: kutLmén, old-man; kutLmímEn, old-voman.

\section{Substantiva Instrumentalia.}

Besides the common characteristic suffix -tEn or -tEl, we have another instrumental suffix in Stlatlumi, viz., min. I observed a few cases of this suffix in Síciatl, but it was not so characteristic of that dialect as of this, where it holds a place equally with the commoner -ten. Sometimes it is interchangeable with it, but not always so; there is therefore an interesting difference in the usage of the two suffixes. I give a few examples of each. Further examples may be found in the vocabulary. 
-ten.

$-\min$.

anchor, nütcámä-ten.

bed, āqếtc-ten.

comb, wếruk ${ }^{\cdot u-t e n . ~}$

language, 'nkwālút-ten.

moon, k'lánäm-ten.

trap, kấkil-ten.

a borer, qútuk-min or qútuk-ten.

adz, klấ-min.

bowl, 'nklaúka-min.

file, zúk'a-min.

paint, Qékwe-min.

spoon, ctlaké-min.

wash-tub, caúq(E-)nin.

\section{Substantiva Offealia et Attributiva.}

These in Stlatlum are formed by adding the suffix -ötl or ōEtl to the substantive or verb, which way or may not be duplicated, thus : a liar, kEkEzốEtl, from kâkäza, a lie. Here the vowels of the term have undergone modification, but this does not always happen.

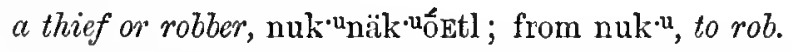

a stuttercr, Es'nátenEtcốEtl ; from Es'nấEnEtc, to stutter.

a tattler, kwālūt-ôttl ; from kwālút, to speck, tell.

a hunter, pukpēEkEm-óEtl ; from péEkEm, to hunt.

a dancer, mōtsōm-ôtetl ; from mótsōm, to dance.

a singer, klēm-óttl or ètētlum-óttl ; from klélēm or étlum, to sing.

\section{Synthetie or Incorporative Nonns.}

These are mainly employed in the Salish dialects when speaking of the bolly or its parts. A few other class nouns such as those for house and trees have also incorporative forms, but they are truly characteristic of corporeal terms only. Thus :

tzāweqḱn-am, to wash one's feet.

tzāwák'-arn, to wash one's hands.

tzaukw-am, to wash one's head.

tzāwốc-Em, to wesh one's fuce.

tzawawátc-En, to wash one's breast.

tzauwáck'welt-am, to vash one's throat.

En-tzaúk-Em, to wash one's bach.

En-tzawä́n-am, to wash one's ear.

En-tzótzaulúkc-Em, to wash one's nose; here the term is reduplicated because of the two nostrils.

En-tzauwālós-Em, to wash one’s eye.

En-tzūtzauwālốs-Em, to wash one's eyes; reduplicated to mark number.

En-tzauwalēmát-Em, to wash one's neck (at the back). 
162 C. Hill Tout.-Report on the Ethnology of the Stlatlum $\mathrm{H}$ of British Columbia.

\section{Pronouns.}

\section{Personal Pronouns.}

Of these there aro three classes in StlatlumH, viz., the Copulative or Enclitic, the Independent, and the Incorporative.

\section{Copulative Pronouns.}

Employed with Indicative mood. Employed with conditional mood.

Singular.

$I, \mathrm{kEn}$ or kan and tlkan. $I$, -an, -En; Ens, Endj.

Thou, kauq and tlkauq. Thou, -auq, -q, cū.

Plural.

We, katl, kátla and tlkatl, tlkátla, $W_{e},-\mathrm{Em}-\mathrm{m}$, -at. Em.

You, kálap, kálapa and tlkálap, $\quad$ You, álEp, -lEp, -Ep. tlkálapa.

The forms employed with the third person are not pronouns, so I do not give them here. They are merely verbal terminations of auxiliary verbs, and the difference between the singular and plural is just the addition to the latter of the plural demonstrative to mark number.

These copulative forms are generally suffixed to the verbs. Sometimes, however, they are prefixed. When prefixed they give a somewhat different sense to the verb.

$I$, me, sEndj or sEntc. thou, s'núwa or s'núa. he, she, it, s'nitt.

\section{Independent Pronouns.}

we, Qic-némel or s'némōtl. you, Qic-núlap. they, Qic-nítl.

Other forms which are demonstrative in character, employed with the verb in the third person, are:-

\section{Singular.}

tā, tāô, tūtēwá.
Plural.

êtūu, Entūēwà ézō.

\section{Possessive Pronouns.}

Of these there are two forms, the general and the selective. Both are more or less enclitic, thus :-

$$
\text { Singular. }
$$

n'-, my, as n'-skáạa, my log.

-cī, thy, as skấka-cū, thy dog.

-c or -ca, his, her, as skáḱka-c, his, her dog 


\section{Plural.}

-tlkatl or katl, our, as skấḳa-tlkatl, or skăḳa-katl, our dog. -lap, your, as skâkka-lap, your dog. -ē, or -êha, their, as sḳáka-ề, their dog.

ten skákạa, my dog. tē skấka-cáwa, thy dog. tē sḳáḳa-ca, his, her dog.

\section{Selective Form.}

tē sḳákâ-tlkátla, our dog. tē skáka-lápa, your dog. tẽ skấḳa-éha, their dog.

\section{Locative Possessive Pronouns.}

This class of prononn has in addition to the possessive element a locative signification, indicating the position of the object possessed, thus :-

\section{Objeet present near speaker.}

Singular.

$m y$, tEn, as ten skấḳa, $m y$ dog.

thy, te' - - cūwa, as te' skẹáka-cūwa, thy dog.

his, her, tc' - - - ca, as tc' sḳáksaca, his, her dog.

Plural.

Our, tc' - . - tlkátla, as tc 'skákạa-tlkátla, our dog.

Your, tc' - - lápa, as tc' skấḳa-lápa, your dog.

their, tc' - . - éha, as te' skấka-éha, their dog.

\section{Objeet absent or distant from speaker.}

Singular.

my, nēn, as nēn skấḳa púkuk’a, my dog is white.

thy, nē, as nē skákạa-cúwa púkuk•u, thy dog is white.

his, her, nē, as nē skákaca púknk•u, his, her dog is white.

\section{Plural.}

Our, nē - - tlkátla, as nē-skấka-tlkátla púkuk•u, our dog is white.

your, nē - - lápa, as nē-skấḳa-lápa púkuk•n your dog is white.

their, nē -.. éha, as nē-sḳáḱça-éha púkuk'u, their dog is white.

These locative particles are the demonstratives "tce" or "tcä" = here and "ne्e" = there. This latter is the common sign for the past in verbs in the Halkōmélem and Sk:qốmic.

Once, in the text of the mountain-goat myth, the form " $\mathrm{kwEn} "=n y$, appears. This form is common in the Halkömélem and is employed when the object is present but invisible to the speaker. 
$16+$ C. HiLl Tout.-Report on the Ethnology of the Stlatlumi of British Columbia.

\section{Substantive Possessive Pronouns.}

These likewise have a general and a selective form, thus :-

\section{General form.}

mine, n'tcứwa,

thine, teưwacū, ours, teúwatlkatl.

his, hers, tcúwac, yours, tcúwalap. theirs, teū-ē.

Selective form.

mine, ten tcúwa,

Ours, tē teūwatlkatla.

thine, tē teúwacū, yours, tē teúwalápa.

his, hers, tē teúwaca, theirs, tē tcū-éha.

These forms are also used with the objoct when they become the equivalent of our emphatic forms, my own, thy own, etc., thus :-

nētl n'tcūwa teítūQ, it is my own house. nētl teứwatlkatl teítūQ, it is our own house.

\section{Ineorporative Pronouns.}

It will be seen that these present considerable differences from the corresponding forms in the dialects previously examined.

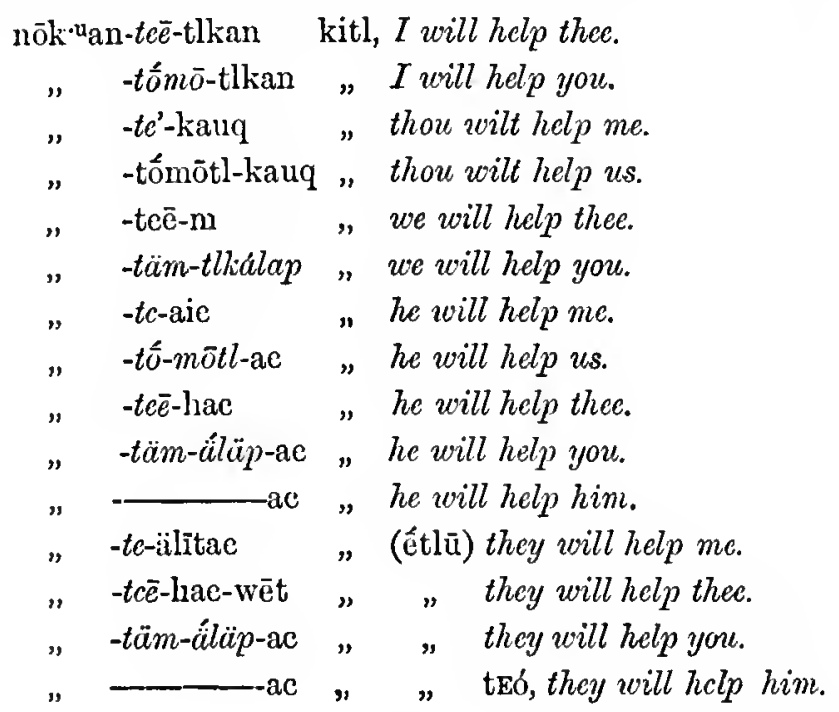

These ineorporative forms appear to be regularly and uniformly employed as we find them with other verbs, thus :-

átsuqEn-teē-tlkan, $I$ see thee.

" -tc'-liauq, thou seest me

", -tee $-\mathrm{m}$, we see thee. 
âtsuqEn-tốmōtl-kauq, thou seest us.

" -tc-ac, he sees me.

" -tốmötl-ac, he sees us.

$" \quad-t c \vec{e}$-ac, he sees thee.

" -tämaläp-ac, he sces you.

\section{Reflexive Pronouns.}

-tcūt.

ka cíkEn-tcūt-kÉna, I struck mysclf (accidentally).

ka " -tcūt-kítla, we struck oursclves (accidentally).

This form is identical with that in the N'tlakipamuQ.

Indefinite Pronouns.

tấkem-cwät, anybody.

cwátac ka, somebody.

Interrogative Pronouns.

cwät or cūwät? who?

cwânōtl ? whose?

stäm? what?

kūn ka? which?

\section{Examples.}

Cwät kō mâitcintáli tceấ tcítūQa? who made this house?

Cwät kauq? who are you?

Cwät tī? who is this?

Cwät teó ? who is that?

Cwät ćtlū ? who are they?

Cwánōtl tceî́ smáit? who did this, ad litt. whose is this work?

Cwânōtl teố tcītūe? vohose house is that ?

Cwấnōtl tEó ? whose is that?

Cwấnotl tceá? whose is this?

Stäm tūō? what is that?

Stäm kwa sqátl-cū? what do you want?

Stiin tīá sqatl-cū? what Do you want?

Nētl kūn ka? which one?

Dcmonstratives.

Singular.

Plural.

tè, tî, tā, tce, tcriá, êtza, the, this.

tế, tūố or tōó, tūtéwa, that.

$\bar{e}$, éha, these.

êtlō or êtlū, Entūếwa, thosc. 
166 C. Hill Tout.-Report on the Ethnology of the Stlatlumn of British Columbia.

\section{Prepositional Pinases.}

En tē kóa, in the water.

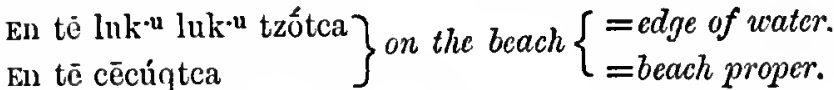

Ectlấ tē tcítūọ, near the house.

En tẽ tcítūọa, in the house.

Ecótluq en tē tcítūea, within, or inside!of, the house.

Entc-tlēk'ta, up in the skyy. (stlếket=sky.)

En tê kutLhá, on the stone.

En tê teméQa, on the ground.

En tè qétc'ma, in the box.

Numerals.

The Salish dialects abound in class numerals and the Stlatlumir marks no exception to this rule. Some of these are given below. The simple absolute forms are as follows :-

1 pála.

2 ánūwäc, or án'wäc.

3 kátlac.

4 qoótcin.

5 tcêllkst, tcilkst.

6 tlâkEmikst.

† tcútlaka.

8 pilóp'st, palópist.

$9 \mathrm{k} \cdot$ 'umpálmin.
$10 \mathrm{k}$ 'ump.

$11 \mathrm{k}$ 'ump wē pâla.

12 k'ump wē ánūwac.

20 án'wac sk'umpc.

21 án'wac sk'umpe wē pála.

30 katlac sk'umpc.

40 qoôtcīn sk'umpc.

50 tcēlkst sk'umpc.

100 nútcEpeqékēnk'st.

It will be seen that the Stlatlum fr forms approximate closely to the N'tlakípamue with the exception of two and ten. The number ten is the most constant of all the numerals and is found with but slight modifications in a large majority of the Salish dialects. This strange form in the Stlatlumn is therefore the more noticeable. The formation of the decades in this dialect is, however, the same as in the N'tlakápamue.

\section{Class Nunerals.}

Persons.

1 man, pấpela, páp’la.

2 men, Encín'wac.

3 " EnkEkatlic.

4 " EnQäıōıötcin.

5 , Entcíltcilkist.
6 men, 'ntlātlák EmkEst.

7 ” 'ntcútlictläka.

8 " 'npálpilópict.

9 „'nk'umk'umpálmin.

10 "'nk'umak'umEp. 


\section{Animals.}

These terms are confined almost exclusively to the smaller kinds of animals :-

1 pÉpalä.

2 áan'wac.

3 kátlitlic.
4 qoốtcin.

5 tcítcilket.

$10 \mathrm{k} \cdot u k \cdot u m e p$.

The interesting feature of these forms is the different manner in which the duplication is effected for the different significations.

\begin{tabular}{|c|c|c|c|}
\hline & $\begin{array}{c}\text { Logs and long round } \\
\text { objeets. }\end{array}$ & $\begin{array}{l}\text { Canoes, boats, ships, } \\
\text { steamers, trains, ete. }\end{array}$ & $\begin{array}{c}\text { Streams, creeks, small } \\
\text { lakes, ete. }\end{array}$ \\
\hline $\begin{array}{r}1 \\
2 \\
3 \\
4 \\
10\end{array}$ & 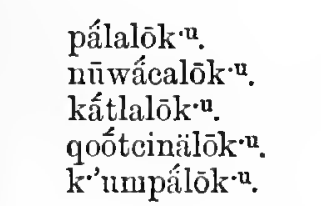 & $\begin{array}{l}\text { palólwētl. } \\
\text { nūwasólwêtl. } \\
\text { katlólwētl. } \\
\text { qoōtcinólwêtl. } \\
\text { k'unipólwētl. }\end{array}$ & $\begin{array}{l}\text { Enåläptkwe. } \\
\text { Enwäcá́tkwE. } \\
\text { 'nkatlátkwE. } \\
\text { 'nqōtcinátkwe. } \\
\text { 'nk'umpấtwke. }\end{array}$ \\
\hline
\end{tabular}

\begin{tabular}{|c|c|c|c|}
\hline . & $\begin{array}{l}\text { Potatocs, apples, dollars, } \\
\text { and other round objects. }\end{array}$ & Houses, tents, ete. & $\begin{array}{c}\text { Spears, arrows, stones, } \\
\text { ete. }\end{array}$ \\
\hline $\begin{array}{r}1 \\
2 \\
3 \\
4 \\
10\end{array}$ & $\begin{array}{l}\text { pálōca. } \\
\text { nuwacúca. } \\
\text { kātlúca. } \\
\text { qoōtcinúca. } \\
\text { k'umpúca. }\end{array}$ & $\begin{array}{l}\text { pálāletc. } \\
\text { nūwācâllete. } \\
\text { kātlấletc. } \\
\text { qoōtcináletc. } \\
\text { k'umpấlete. }\end{array}$ & $\begin{array}{l}\text { pálalitc. } \\
\text { nūwácalitc. } \\
\text { katlálite. } \\
\text { qoōtcinálite. } \\
\text { k'’umpálite. }\end{array}$ \\
\hline
\end{tabular}

The difference in sound between the last two classes is so slight that a European ear has difficulty in detecting any; but there is a distinct difference to the Indians. In counting with class numerals it was customary always to name the class object with the first number and again with the tenth.

first, kéla or kíla. second, an'wit. third, EtinkEkatlactca. fourth, Etinqōqōtcintca. fifth, Etintciltcilkistea.

\section{OrprNals.}

sixth, Etintlaketlkum-kictca. seventh, Etinteūtltlakatca. eighth, Etinpalpelōpistca. ninth, Etink.'umk'umpalmintea. tenth, Etink'umk.'umeptca. 


\section{Distributives.}

one each, pīlpála.

two „e én'wac.

three, è kätletlác.

four " è qoôtcin.

five „ e teílkist. six each, è tlákEmikst.

seven, " ē ten̄tläka.

eight „ è palópst.

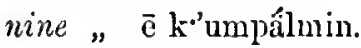

ten,$\overline{\mathrm{e}} \mathrm{k} \cdot \mathrm{ump}$.

\section{VERBS.}

The inflection of the verb in the Stlatlumn is effected, as in the other Salish dialects examined, by means of affixes and auxiliary verbs. The regular past is formed by adding $t \bar{o}$ or $t \bar{u}$ to the present stem. A modification of this particle is effected to express very remote action by a lengthening or duplication of the vowel, thus :- to-ó or tu-ó. The longer the vowel is drawn out the remoter the aetion or event. This particle is the equivalent of the êt th the Halkómélem and the ôtl of the Síciatl dialects. There appear to be no forms corresponding to the $\bar{e}$ and $n \bar{e}$ of the Halkómélem, or to the $t \bar{e}$ of the Síciatl and Skqqómie. The simple future is formed by the addition of the particle kitl. It will be seen that this is different from any of the forms employed to express futurity in the other dialeets examined, each one possessing a form peeuliar to itself. There is a conditional future which is formed loy prefixing the particles tai and hōi. Thus, "tai hối-kan-kálmin," I shall sure to be hungry, said by person who eontemplates going a long time withont food. Again tai hối kan-ûlsun, I shall be sick, said by person who thinks he cannot escape a prevalent siekness.

This particle hói is apparently the same as that which marks the regular future in N'tlakájamue.

\begin{tabular}{|c|c|}
\hline \multicolumn{2}{|c|}{$\begin{array}{l}\text { BSTANTIVE Verbs. } \\
\text { Present Tense. } \\
\text { sicl, âlsum. }\end{array}$} \\
\hline IkIn-îlsum, I am sick. & katl-ñlsum, we are siek. \\
\hline $\begin{array}{l}\text { kuq-ĩlsum, thoo art siek. } \\
\text { wã-îlsum, he, she is sick. }\end{array}$ & $\begin{array}{l}\text { kélep-ấlsum, you are siek. } \\
\text { wà-wēt-âllsum, they are siek. }\end{array}$ \\
\hline
\end{tabular}

This tense may be otherwise rendered. Thus we may say :âlsum-tlkan, $I$ am sick.

âlsum-tlkatl, we are siek.

The differenee in meaning between the two forms in substantive verbs is that the former is enployed to express a statement of fact, the latter is used in answer to direct questions and may thus be called the responsive form. It means also more than the former, and is best rendered thas: "I am and have been sick for some time past"; when the sickness las been of long duration this is expressed by dwelling upon the initial vowei or syllable, thus: a $\ldots$ lsum tlkan, $I$ am sick a long 
long time. This of course is a very primitive method and is commonly employed in all uncultivated languages. It is also the method employed by children in their speech. The superlative degree in comparison is likewise thus commonly expressed :-

\section{Pust Tense.}

ken-tō-ấlsum, $I$ was sick.

kuq-tō-âllsum, thou art sick. wai-tō-âlsum, he, she is sick. katl-tō-ấlsum, we are siek.

kélep-tō-âllsum, you are sick.

wä-wēt-tō-âlsum, they are sick.

This form is the equivalent of the Halkōmêlem "kâkai-êtl-tcil," I was sick.

There are several ways of expressing the past in Stlatlumis. Thus I may say âlsum-tlkan-tūô, signifying by this prolongation of the temporal clement tô that I have been sick, but am at the moment of speaking nearly well again. Or I may say, wai-tlkan-âllsum, I have been siek but am now avell.

It is interesting to note that this past particle "to" has an independent function, and is primarily a locative adverb, neaning " there." The corresponding ne or le form of the Halkōmélem has the same double function and meaning, though in the interior it is employed by some of the tribes to express future states and actions. We get here a fine insight into the workings of the primitive mind and may perceive how the "temporal " elements of verbal conjugation are sometimes evolved. With the Salish speaker time holds a very subordinate place in his verbal syntheses. It is place rather that his mind dwells upon. Actions and states are always conceived by him as taking place somewhere rather than at sometime. If it be necessary to mark the time this is done by using an independent temporal expression as "yesterday," "to-morrow," "next moon," "last moon," and so on.

But when this is not necessary the "past" and the "future" are both expressed by a term of local signification, that is by an adverb of place. It is not difficult to understand this. Both "past" and "future" actions are equally away from the speaker, are both over "there." There is a "there" of the past and a "there" of the future, and thus we can understand how some of the Salish tribes have come to employ the locative ne to express "future" actions and states, and others the same particle to express "past" actions and states.

\section{Future Tense.}

kEn-âlsum kitl, I shall be sick. kuq-ấlsum kitt, thou wilt be siek. âlsum kitl, she, he will be sick. katl-âlsum kitl, we shail be sick.

kálep-âlsum kitl, you will be siek.

âlsum-wēt-kitl, they will be sicl.

The form-

âlsum-tlkan kitl, $I$ shall be sick, âlsum-tlkatl kitl, we shall be siek,

is also employed, but conveys a sense different from the other. 


\section{Periphrastic Form.}

Entc'petếnōcim kwendj hōz ẩlsum, $I$ think $I$ am going to be sick.

\section{Negative Forms.}

Qoāz kwendj wā âlsum, not I am sicki.

Qoāi kwacū âlsum, not thou sick.

Qoāz kwa-tlkatl âlsum, not we sick.

Qoāz kwendj wā qấtlemīn kwendj wā âlsum, not $I$ am desire $I$ am sick, or $I$

don't want to be sick.

\section{Conditional Forms,}

Etl-tcākwan-En tcEấ tē âlsum-tlkan kitl, If I eat this I shall become sick. Etl-îls'inEn kitl, when $I$ am sick.

skánas kwendj wā âlsum, I may be, or perhaps $I$ shall be, sick.

\section{Miscellaneous Forms.}

Qoāz kwendj wā áloc kwendj âlsum, $I$ am not often sick, verbatim, not I am often $I$ sick.

pấpet-kan klō wã ẩlsum, I am often sick.

wā-kauq-ha-âlsum? are you sick.

wā-tlkan, I am. Qoāz, kwendj wā âllsum, no, I an not sick.

wā-ha âlsum? Is he sick? wā, yes, or he is.

plan tlkan-wā-âlsum, I have bcen sick already.

tai hói-âllsum, I shall be surc to get sick.

\section{Interrogative Verbs. \\ Näc, go.}

\section{Present Tense.}

I go, näc-kam.

thou gocst, natc-kauq.

he, or she gocs, näc. we go, nác-katl.

you go, nấc-kálep.

thcy go, näc-wèt.

The past of this could be rendered by adding the locative particle to to the present forms, but the past of this verb is not customarily used. They employ instead the verb tcêoq which has a double sense of "to go" and "to come." Thus "I went" would be rendered: tcéoq-kan-tō. The other "persons" would follow in like manner.

\section{Future.}

näc-kan kitl, $I$ shall go.

nấc-katl kitl, we shall go.

The other persons follow regularly in like manner. 
Conditional Forms.

skínac-kitl kwens-näc s'ente, perhaps I may go.

skánac-kitl kw'e-näc teūs'núwa, perhaps thou mayest go.

skánac-kitl klō-kw'c-näc snītl, perhaps he, she may go.

\section{Imperative Forms.}

näe, go.

näc-kauq, go you.

näc-kauq, go you.

näc-matl, go!

Miseellaneous Furms.

ámatl nác-auq, you had better go.

In this expression the adverb áma takes the imperative inflexion.

kwendj-näc, that $I$ should go.

nètl kitl 'tlō-ens-näc, then will I go.

In the N'tlakapamuq we find two distinct copulative pronominal forms, one used exclusively with intransitive and one with transitive verbs. We have two forms also in the StlatlumH, but they do not appear to be employed in this way in this dialect. I can find no rule for their use other than that I have given mule 1 "substantive verb." In some expressions they appear to be used interchangeably.

I strike, eiken-tlkan ;

thou strikest, eíkEn-tlkauq;

he, or slee strikes, cik'nac ;

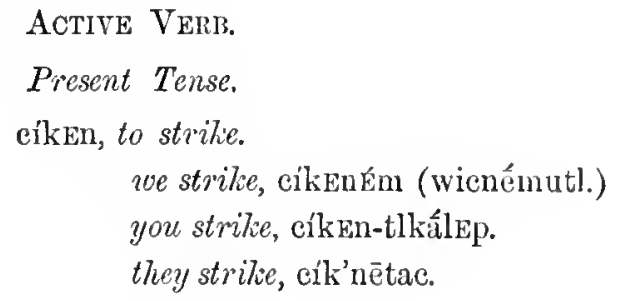

Past Tense.

eíkEu-tlkan-tō, $I$ struck. cíkEnÉm-tō, we struels.

The other persons follow regularly in like manner.

\section{Future Tense.}

cíkEn-tlkan kitl, I shall strike.

eíkEnÉn kitl, we shall strikie.

The other persons follow regularly in like manner.

\section{Imperative Forms.}

strike! cíkEn!

strite now! cíkenmatl! or eíkEn wiì-matl! strike you ! ciken ē matl or cíkEn-ê-wā-matl! or hōhớmatl cíkEn! let me strike it, s'utcús kō cík En tấlē. 
172 C. HII.I. Tout.-Report on the Ethnology of the Stlathmin of British Columbia.

\section{Obligative Forms.}

I must or ought to strike it, tē cíksn-tlkan. you onust or ought to strike it, tê cfken-tlkauq. we must or onght to strike it, tē cikEnfm.

\section{Conditional Forms.}

when I strike, kwendj plan ciken. when thou strikest, kw's plan' cū cfken. when we strike, kw's plan cíkEnEm. when you strike, kw's plan-'lép ciken.

\section{Optative Forms.}

I wish I could strike it, $\mathrm{nE}^{\mathrm{s}}$-qat-l or 'nsqat-l kw's cfkEn-En.

I wish we conld strike it, nE $\mathbf{E}^{\mathrm{s}} \mathrm{qat} \cdot \mathrm{l} \mathrm{kw}$ 's cikEn-Em.

I wish thou couldst strike it, $\mathrm{nE}^{\mathrm{g}} \mathrm{qat} \cdot \mathrm{l} \mathrm{kw}$ 's cikEn-auq.

I wish you could strike it, nE qat-l kw's ctk'nálep.

\section{Interrogative Forms.}

Did he strike it? efken-ac wentc? or cíkEn-ac-ha ? $Y$ es, he struck it, cíkEn-ac.

Did you strike it? ciken-kauq wentc?

I did, wấ-tlkan.

Orıght we to strike it? hōz wentc cíkén-Em?

\section{Deprecative Forms.}

Pleasc don't strike it, s'áluks qoāz kwácū cúken.

Please don't strike me, s'íluks Qoāz kwácū cíkentc.

\section{Reciprocal Forms.}

Let us strike one another, hối-tlkatl-cíken-tūäl. they fought each other, ka uāz-tūál-wêta.

\section{Iterative Forms.}

I am repeatedly striking it, wātlkan cikecken.

\begin{tabular}{|c|c|c|c|}
\hline e are & $n$ & " & wātlkatl cikclkEn-Em. \\
\hline thon art & 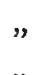 & ” & wātlkauq cikEckEn. \\
\hline
\end{tabular}

It is interesting to note that the duplication for the first person plural is different from that of the others. 
C. Hind Tout.-Report on the Ethnology of the Stlatlum $\mathrm{H}$ of British Colembiu. 173

Negative Forms.

Present Tense.

I do not strike, Qoäz kwendj wā cíkEn.

thou dost not striłie, Qoāz kwấcū cík Eu.

he does not strike, Qoāz kwā cíkEn1-ac.

we do not strilie, Qoāz kwā cíkEn-Ém.

you do not strike, Qoāz kwälap cíkEn.

they do not strike, Qoāz kwā cik' nétac.

Past Tense.

I did not strike, or I have not struck it, Qoāz kwendj wā-tó cík kn.

we did not strike it, Qoāz tō-kwā cikEn-Ém.

Don't strike it! Qoāz kwā cū cíkEn!

Don't strike me! Qoāz kwā cū cíkEntc !

Infinitives.

to strike, cikEn; to have struck, cilken-tō.

Passive Voice.

Struck, cik.

Present Perfect Tense of Accidental Action.

I am struek, cikstōmIấlkm.

we are " cikstōmólem.

thou art , cikstōmém.

you are ," cikálep.

Present Pcrfect Tense of Purposive Action.

I an struck, cikentcấlem.

we are " cikentōmólem.

Recent Past Present Tense of Aecidental Action.

I have been struck, cikstômHālem-tō.

we have " cikstōmólem-tō.

Recent Past Perfect Tcuse of Purposive Action.

I have been struck, wā-tō-cíkEntcálem.

we have " wā-tō cikentōmól Em.

Remote and Past Perfect of Accidental Aetion.

$I$ have been struck, cikstōmHälem-tō... $\overline{0}$.

we " " cikstõmólem-tō... $\bar{u}$ 
174 C. Hill Tout.-Report on the Ethnology of the StlatlumII of British Columbia.

The longer the voice dwells upon the final vowel of the tense suffix, the more remote is the action.

Intmediate Past Perfect of Accidental Action.

I was struek, wā kā cikstōmHálema.

we were " wā kā cikstōmól'na.

Immediate Past Perfect of Purposive Action.

$I$ uas struck, wā cikentcálem.

we vere " wấ cikentōmólem.

Pluperfect.

cik-kan-tō, I hud been struck.

cik-katl-tō, we

Future.

cík stōmuálem kitl, 1 shall be struek (accidental action).

cík-kan kitl " " (purposive action).

cik-tōmólem kitl, we " " (accidental action).

cik-katl kitl, we " " (purposive action).

cíkEn-tcūt-kan kitl, I shall strike myself (if I do this).

ka cikEn-tcūt-kan, I struek myself (accidentally).

ciken teil mac kitl, I shall be beaten. (I know I deserve punishment.)

Etl c'k-an kitl, If I am stmuck. Etl c'k-at kitl, If we are struck.

Miscellaneous Phrases.

I burnt it, rólEn-tlkan.

I bumt my hand, kwetlpäkä-tlkan.

I burnt it all up, rốlen-tlkan-tō tákem.

I must go soon, kälíl kwendj nïc, or 'ntlōs natlte nEcnäc.

The moon will rise soon, kälaíl tcítleps tē k’länämtena.

onc dog, pála sḳákạ.

tzo dogs, án'wïe skấḳa.

fow dogs, Qoāz skiáka (?)

many dogs, Qōait sḳ́kía.

crevy dog or all dogs, tấkEm ē skấḳa.

no dog, goãz kátī kwa skị̂́ḳa.

one hat, 'npFprlaúk $Q$, or pála kamót.

tưo hats, án'wac kamốt or nan'wacaúk'o.

all the leats, tấk im è kamóta.

no het, qoãz kitīi kwa kamót.

one house, pála tcítQ, or päläletc.

turo houses, ánūwac teítQ, or 'n'wacél'te. 
one stone, pála kEtla or pälälitc.

is it a stone? ketla-ha ti ?

is that a stone? kEtla-ha tEố?

this is a stone, kétla tcEá.

which stone? nētl kūnkẩ kÉtla?

Is that a black stone? kwōqkwếEq-ha tê kétla?

what kind of stone? stäm tē kô kétla?

I have a dog, wä-tlkan Eckäka.

you have a dog, wā-tlkauq Eckákạa.

we have a dog, wā-tlkatl Eckấḳa.

we have some dogs, wā-tlkatl En-ketltc'-skákạa.

he has some dogs, wā EnkEtlte-skạ́ḳa.

my dog is black, knōqkwéEq ten skákka.

your dog is white, skấḳacūwa puk.

my hat is on the table, ten kamóta wă Esk'êl, or wā Eck ểl ten kamôta.

in the box, 'n tī luute'ma.

where is my hat? Énka tō néna-kamóta?

Note here the use of tō, the locative adverb "there," to express absence of object; $\mathrm{nEn}$, is the "absent" form of the possessive pronoun, and the final a attached to it is the interrogative sign.

on that stone, En tEố kÉtila.

sit near me, mêtcak Ec-tla s'Endj.

come with me, cếma Ec-ôlōe s'Endj ; or cếma è'wä Ec-Enclj (or Éntcem).

come home with me, óqwel ćwä Ec-Endj.

I will go with you, nac-kan éwä Ec-núwa, or nẩckan ếwä mếntcin.

let us build a house, Hối wē mēcâl'te. .

let us makie something, Hối wē mầit.

let us build a canoe, Iối stố më caúetl.

let us go therc (several people), Hốhōictūē tūố, or Qíatcūc Ette-ô tūó.

let us go there (trvo persons only), Hōhōic EtEó tūó, ōr qíatcūc etế túóo.

come here, cếma Etcá.

come this way, EntcítEm Etcâ.

the moon is bright, tcitletctlem tē $\mathrm{k} \cdot$ 'länämtena.

the day is clcar, qooqoqkwem.

it is cloudy, Esk'um'p, ad litt. he (mcaning the sun) is shut up.

he is making a fire, wā pấm'cEm.

give or bring me the dog, cêmac skâkkacúwa.

are you cold? tcótlōmskauq wentc?

yes, or $I$ am (in reply) wā or ê.

is he sick? wā wentc âlsum?

he is, wā, or wã âlsum; no, Qoāz, or qoāz kwäc âlsum, no, he is not sick.

is your father dead? zōk-tō wente nē skátzacúwa? yes, $\overrightarrow{\mathrm{e}} ;$ no, Qō̄z. 
176 C. Hrul Tout.-Report on the Ethnology of the Stlatlum of British Columbia.

is he eoming? tcEấc kitl?

when did you eome? ēkấnmacac Etl tléakauq? yesterday, ē nâtūQac.

when you come in shut the door, uEkēuq tcantlkauq tlótlwauQ.

when did you kill it? èkánmacac etl-zókcauq?

when will you kill it? kānmacác kitl Etl-zókcauq?

when you are sick you must take medicine, etl âlsumauq kálwatentlkauq.

when the dog saw me he ran away, átsqEntcac skạkḳa Qólil mêntcEc.

when it rains $I$ stay in the house, kan-tlō Ec-ôtlōq Etl tlō Ec-kwic.

would you like sone meat? Qoāz-ha kwa-cū-qat'lmēmkō tcē ?

The Salish tongues always employ the negative form in questions of this kind, thus; would you not like some meat?

$I$ must drink, ken ${ }^{\circ} \mathrm{k} w \mathrm{E}$.

I ought to drink, áma kwendj ókwE, or âmatl ók-an; verbatim, it is good that

I driuk.

I am eating mcat, ken-tcē tcīnEm.

which is your dog? nētl kō Énka sḳ̂́ḳacū?

he stole my dog, nauk·HōtcEc tEn skákạ.

he stole your dog, nauk'Hëtcēhac skạ́ksacúwa.

he killcd my dog, zôkcec nen-skákła.

I lost my dog, pílip-tlkan nEn-skáḱạ

he lost his dog, pílipeEc nē sḳáḳaca.

(The function of $n \mathrm{E} n$ and $n e$ in the last three sentences, will be understood by referring to the possessive pronominal forms.)

it is raining, wã kwic.

it rained yesterday, wā kwīc ènát'Qac.

it will rain to-morrou, kwīc kitl nátūe.

it may rain to-norrow, kwic kitl etl-p'cīl-Ec.

if it rains I shall not go, ktl wic kwīc Qoāz kwendj wā näc.

where are you? Én-ka Etl-wấ-auq?

I am here, En-tceî́ wá-en.

where do you live? Én-ka tlauq-wā?

$I$ live here, En-tceái tló-En wã.

I live at Port Douglas, En-kō Port Douglas tlō-Eu-wā.

where is Jolen? En-ka tö kw'c John?

he stays in that house, En tūố tcíte tlō wấ-ac.

he is down on the beach, Enkōó teúqtea.

I fish, ken-teü k'wāzem ; a fisherman, tcāk·tzókwazEm.

ure you coming? tceác-kauq kitl wentc?

I often go there, pitpet kwendj wã näcāte.

come in, céma ótluq, or ótluq tlō.

dìl you shoot a deer ? kōc qitkauq wentc tē sk ‘lóla ? 
is it dark? $\mathrm{k} \cdot \mathrm{l}$ Épet'l'pem aitl?

I want you to go, nesqat $\cdot 1$ kwä cū-näc.

it is Harry, nētl Harry.

once he came to my housc, pấla tō kw'c tléakuc ếten tcít $Q$.

when 1 came in the man was lying on the bed, tléak-kan ótluq wā Ec-áqaitc skaíaqa.

$I$ saw hin when 1 went out, åtsqen tlkan Eutlac Ens-näc ótska wã Ec-áqaitc.

$I$ am hurt, qan-tlkan.

you have hurt me, qantctōmrkauq.

who made this? cōwät kō mấitcintâlè tceấ?

$I$ did, c'Entce; he did, c'nitl.

he has killed it, zōkE-nōQ-c.

$I$ want some water, ken-qat-lmin kōkō.

he said he was going, wā-tcūt kwäs näc.

I am hunting (habitnally) wa-tlkan-péklím.

I hunt, ken-péEkEm.

$I$ danee, ken-môtsōm.

I sing, ken-klélēm, or ken-êtlem.

this house, tc Eä́ tcītñoa.

that house, tō tẹ lấka tcítūe.

these houses, ê-za tcítn̄ea.

these houses, ế-tlō tcítūea.

those houses, ē-láka unteó teítūQ.

right eye, 'nzehâlōca.

left eye, 'ntcuk-álōca.

both eyes, tūacâlōs.

right ear', 'nzehalä́na.

left ear', 'ntcuk'w Eâna.

both cars, è 'ukléna.

right hand, n'zEhāka.

left hand, 'ntcuk'wấka.

both hands, è 'nkwekÉcta.

right foot, tensáka.

left foot, tensêk ·äka.

both feet, è 'nskwáqta.

Mytis and Tliaditons.

Kaiyấn.

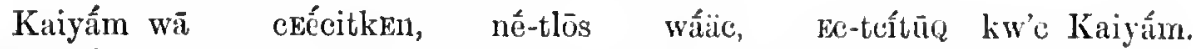

Kaiyắm was "keekwilee"-house, then she lived there, it-housed Kaiyăm.

Rap aitl, nế-tlōs ro-itc, né-tlōs kwelékwilauqe né-tlōs teéq̨e kítē kóa.

Evening now, then she slept, then dreamed-she, that went-she into-the water. 
P'cil aitl nê-tlōs QákEc, nê-tlōs mêteakc, nế-tlōs tấtleline, nế-tlōs aitl Morning now then awoke-she, then got-up-she, then stood-up-she, then now mátukc, 'ntcếtem auk·u kō kóa, nế-tlōs tcēofe ank ka kō kóa, né-tlōs walked-she, entered-she into the water, then went-she into the water, then méteake fnn tī cícaktca. Tcélacac tē skweêkwilauqea, nê-tlōs átsuqEnac sat-she on the bank. She-did-like as-in the dream-her, then saw-she té stzókwāza 'nkwónam stzókwāza. Nê-tlōs käláqucaca nē skweékwilauqca. a salmon (a) soft-roe salmon. Then recalled-it-she the dream-her.

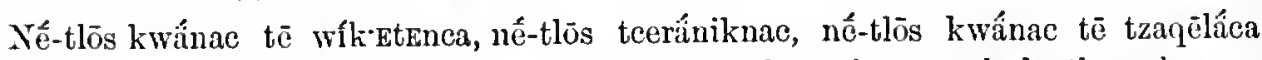
Then took-she the knife-her, then eut-it-open-she, then took-she the long tē kwớna, nē-tlos tzäwánac, nấkenac skūkuméit, nē-tlōs tcúnac kw'c the roe then washes-it-she transforms-it-she a baby, then bade-she-it élale. Nē-tlōs teūnamteanac "n’kókwa" teūn. Nē-tlōs tcūts tē to cry. Then tanght-her-she "my grandmother" to say. Then says-she the

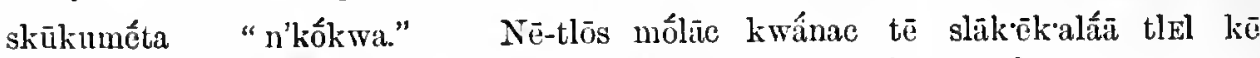
baby "my grandmother." Then again took-she the short

kwóna, nē-tlōs tzäwấnac, nē-tlōs skūkuméil wêylins. Nē-tlos tūkenac, roe, then washed-it-she, then a baby becomes it. Then took-them-up-she, kíla áma te’p'ténōcimea. Nē-tlōs tâtlelins, stúkcece túācakamínes e very good feelings-her. Then stood-up-she, held-them-she in-both-arms the umématsca.

grand-children her.

Nēetlo aitl cnäcite ḱti tcítūqca, nē-tlos kêteēnac, ámac skwákūkca. Then now goes-in-she the house-her, then puts-them-down-she, good-is heart-her.

Ne-tlōs ámac kwácece Né-tlō aitl lālíltamī Then well cares for-them-she looks-after-them-she. Then now become-big

ématsca Skaiyám. Nē-tlōs âlseme, nētlōs kwālúttec Skaiyam grand-children of Skaiyam. Then sick-becomes-she, then speaks-she Skaiyam

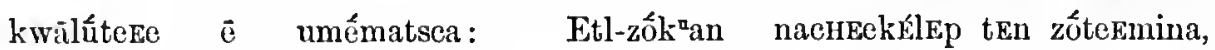
instructs-them-she the grandehildren-her: When dead-I am take-me-you ny red-paint, môta ten Qéaukca, móta tEn tōtlkīea, mốta tEn qoếta, mốta ten tcēékutena, also my black-paint, also my stone-hammer, also my wedge, also my speär, móta ten hốnita, môta ten k·lî̀za, mốta ten lúkwa, mốta ten nEwanékena. also my paddle, also my canoe, also my basket, also my fisher-skin-head-dress.

Etl-2ớk"an Etéó Elt-näctamkélep tĩ stcélukca; q'ócin ketl eskaít nē-tlōs When I am dead yonder then go-you that point; four shall be days then

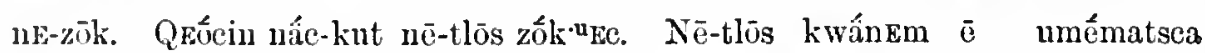
my-leatl. Four went-by then dies-she. Then take-her the grandchildren-her, nē-tlōs 'ntlamáinem En tē klí́zca, nē-tlō aitl näc-tam étī qatlmēnáca. Nē-tlō then put-her in the canoe-her, then now take-her where desired-to-go-she. Then

aitl tcếuks-tom Ékē umématsca tákum ē stEm-tÉtEmca. Nē-tlō aitl now placed them by the grand-children-ler all the belongings-her. Then now 
qêlēnem Entlemtlam En te k·lấzca Skaiyam. Tcūq aitl kw'c k·él’ainEm laul-her-np lying down in the canoe-of Skaiyam. Finished now putting-her-away, nē-tlō aitl tl'wélnem ékē umếmatsca. Kamatlák sū sk'úmpa; then now she-is-left-behind by-the grand-children-her. It-is-a-beautiful-day warm; óqwel-wēt aitl. Nē-tlō aitl óqwEl-ē, tcếoq-wEt aitl tē tcîtūe-ćha; tē tcítūe-êha go-home-they now. Then now home-they, go-in-they now the house-their; the house-their cécítken. Nē-tlos élal-ē; nē-tlōs rōit-ē. P'cīl aitl nē-tlōs is-a-"keekwilee-house." Then lament-they; then sleep-they. Morning now then mêtcak, nē-tlōs ôtska snúkuma, nē-tlōs k'umps, nē-tlōs ótskac tē slīlämqa. sit-up, then outside (the) sun, then warm, then goes-ont-she the elder.

Nē-tlōs tcêoqEs aúkuăltzuka, nē-tlōs mêtcaks, kamatlákū sk'umpa, Then went-she to-a-distant-point, then sat-down-she, the-day-is-beautiful warm nē-tlōs kanémec kwäweaú, nē-tlōs kalânEc, nē-tlōs kanếmEè, nē-tlas kō tē then bears-she, shouting, then listens-she, then hears-she, it-was erst-wlile the $\begin{array}{cccc}\text { kwókwaca } & \text { wanhEnhEm. Nē-tlō aitl skwâlnEc tē cickwōza: } \\ \text { grandmother-her } & \text { calling-out. } & \text { Then now asks-she the younger sister }\end{array}$

"Ti Qōnauq-ha-tlō zōke Skaî́yam?" "Qonauq-tlō zōk. Q Qōnauq-tlō zōk sEấluke." "Is it true dead Skaíyam?" "It-is-true dead. Yes dead sir."

Nè-tlō aitl Hấtelin; nē-tlōs qêlēnec tē k-lâzca; nē-tlō aitl s'tekcáits, nē-tlōs Then now lands-she; then lauls-she the canoe-her; then now comes-up-she, then ótluqs tē síyuktca, nē-tlōs kwânäc tē slauwếna, nē-tlōs teäkwẩnac. S'tceác goes-in-she the girl, then takes-she the ruat, then spreads-it-she. Enters-she "uitl ôtluq ute écilkena; ne-tlō aitl métcake en te' slauwéna. Nē-tlōs now into the "keekwilee-house"; then now sits-down-she on the mat. Then

kwánäc tē IrElákra, nē-tlōs nácitc 'nzaúqom tē skílämqa; nē-tlōs k'cnänäc, takes she the water-basket, then went-she for-water the elder-one; then bade-she, nē-tlōs tcúnac: “nac kwäm kw’e p’ämic Ekố-älsEkẩ." Nē-tlōs k•lếEkcec, then said-she: "go get some fire-wood outside-there." Then comes she, stukcấc è spámica. Nē-tlōs tcúnEm Étē kEqkeqca "päm’eEm atl : brings-she much fire-wood. Then bidden-she by the elder sister-her "make-up-the-fire! kauwōkmatl!" Nē-tlō aitl kwấnäc tē skílamqa tē nōkwâtena, nē-tlōs heat-the-cooking-stones!" Then now took-she the elder-one the cooking-basket, then

'ntlấliwänac, nē-tlō aitl tcēqaím. K`wol aitl. Nē-tlōs kwānäc, nē-tlōs put-in-water-she; then now boils. Cooked now. Then took-she, then

EnkētcanEkEnae, nē-tlō aitl tlómic tē skaíkqwa qoāz kwāeka écaucáca placed-before-hin-sle, then now spoons-it-he that man not able to chew

ē skam'ca; wā-tlō-eslaúwa etl-wiclákwoncece è skám’tca. Tcúk·walite the roots; he-covered-up-his-mouth when-he-spat-out-it the roots. Finished-eating

aitl tē skaíEqwa; nē-tlōs tátlelin, nē-tlōs kwiskwícits; nē-tlōs ōtskac-tō now that man; then he stood up, then dropped them; then outside-went-he.

Nē-tlōs atsuqkenac tē tce lílina è skám'tca; nē-tlōs teùts: "wā-kánen Then perceived-she the younger the roots; then said-she: "why 

he Qoāz kwac sákwanac ē sliam'tca?" Nè-tlōs tcūts tē skílämqa:
not

"Ke-wic-kínen." Cnempmok" kō à tē nūwanékena tē skaíkqwa, "I lon't know why." Bound-around-head with a fisher-skin that man,

Ec-metcóc Étē zôtsemina, mốta tē QếEqca tce metcóctca, Ec-tlūkēin, mark-face-he with the red paint, also the black-paint mark-face-his, he-purts-his-hair,

enzúcak ko tē skaî́Eqwa, tē tlếeka skaíteqwa ḱkē k’umk'amaza. Rap he-dressed-his-lair that man, that goes man with-the young-women. Night aitl. Nē-tlō aitl áqētc-ēe, Eskwutämetcūwēt tē skílamqa áqētc now. Then now lie-down-they, they-have-intercourse-together the elder lies 'nzáEtnếwetce tō ska1́Eqwa, áqētc tē tcelána tē 'ntcek'uátlnéwetce tēe ou-the-right-side-of the man lies the younger on-the-left-side-of the skaíEqwa. Nē-tlōs tcēmōcmínac tē skílamqa cimámic. Nē-tlōs k’lókónac, man. Then faces-he-towards the elder wife. Then embraces-her-he, nē-tlôs nōkménac aitl tcimám'ca. Tcúk 'uce tê skílamqa cimámic, then has-interconrse-he now wife-his. Finished-with the elder wife, p'ElkốcEm aitl Etē tcealấna cimấmic; nōkménac aitl tce lä̉na he faees now to the younger wife; he-has-intercourse-with now the younger cimấmic. Tcūk'u aitl, Ensk'am-malếoqcem, rốit-to-wèt aitl. P'cīl aitl, nē-tlōs wife. Finished now, he-lies-breast-upwards, slept they now. Morning now, then mếtcak-ē nē-tlōs ótsk-ē tákum-wēt-tlō, tcéoq-wet. Nē-tlōs nácitc get-up they then go-outside-they all-of-them, went out they. Then goes he skaíeqwa eteó kekaúa. Nē-tlōs kwälútec teE lílina; nē-tlōs kwälútcec tē the nan there away off. Then spoke the younger; then said-she-to the kŕqkeqca; "Pūpaú-tlkan." "K·ailem-tlkan-tlō tlēt, pūpaú-tlkan-tlō tlēt," elder-sister-her ; "I am swollen." "The same I am too, swollen-I-am also," tcūt aitl tē skílämqa; "Etl-rápec " kitl móta cếtict aid now the elder; "when night-it-is shall-be next at-midnight hōz-n’kúk'EzanÉkEnEm, nē tlōs zwotnem kitl." "Nētl tcūwáca Ecmīitc let-us-make-him-laugl, then find out shall." Last-night his is closed-month

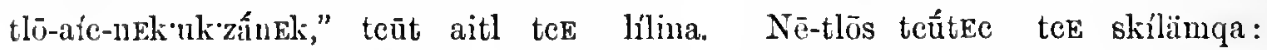
when-he-laughed," said now the younger. Then said-sle the elder:

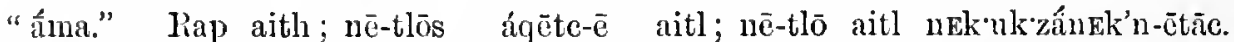
"all-right." Night now; then lie-down-they now; then now tickle-him-they.

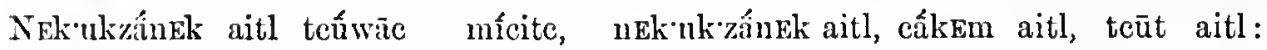
Laughing now his mouth-closed, laughing now opening now, he says now

"ha! ha! ha! ha!" Nê-tlō môta teūts: "Teūk ustōmińlī, s'f́ntcem "ha! ha! ha! ha!" Then also says-he: "Let-me-alone, it-is-I

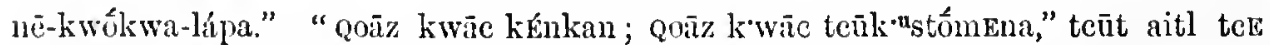
grandnother-your:" "Not cun stop; not can let-yon-alone," said now the shílämq̨a. Zūk aitl Skaíyam. P'cīl aitl, kwánac aitl skílämqa k'tláliqen, elder. Dead no Skaiyam. Morning now, takes-she now the elder a-rope, 
āzémFn-êtac Eck'wúmk'wum nē-tlō aitl túkEn-êtac, qấtEn-ếtac, mâtuk tie-up-they-her knees-drawn-up then now lift-her-up-they, raise-her-up-they, walk

'n tcếtem tcćoqwēt aitl; nē-tlō 'nslāmắn-ētac tē k-lâzca tē k’lâza stcíma to the water reach-they now ; then place-her-in they the canoe-her the canoe big-tub (the water)

skwătcitca. Nē-tlō 'nkauwanếtac nemkấl-wēt, tcếoq-wēt, aitl tekokaūa nē-tlōs its-name. Then set-off-they paddling-they, arrive-they now far-out, then

tukEn-êtac, 'nkumkwan-êtac, nē-tlō 'n'mấactce, nē-tlōs ōwélim'c ; lift-her-up-they, put-her-into-the-water-they, then she sinks, then bubbles-appear; klelk·lolackōhen aitl, Eckwél. Óquel-wèt aitl, tcéoq-wēt Etc' very-still-water now, it is balmy. Go-home-they now, arrive-they at the

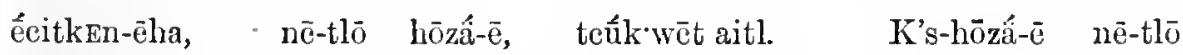

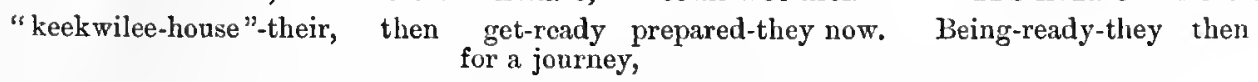

ôtsk-ē, nē-tlō mätuk-ē 'ntcếtem kwinkumkéna stūaúkqa. Teēoq-wēt aitl go-out-they, then walk-they towards head of the creek. Arrive-they now éwā-Ec-tcítūQ, ótluq-wēt aitl; wā skūkumêta, cEékwatl, mốtā tē where-was-a-house, go-inside-they now; there-was a baby, a-tiny-baby, also an kutLménina; Ec-nÉmEnEm tē kutLmémina. Wā-ćlal tē skūkuméta. old-woman; she-was-blind that old-woman. It-was-crying that baby.

Nē-tlō tcūts tē k’ámaza, tē skílämqa: “Tcúnac tē kutLmémina,
Then said the maid, the elder-onc: "Bid-her the old-woman,
(to her sister)
(to her sister)

cauQEnskaúqka!" “Qon̄z kwendj ka qî́tltca." “Ama, cauq’nếmetl, wash-you-it!" "Not I can-do-it." "Very well, wash-it-we,

rốit-kitl." “Áma." Tē skílämqa nē-tlōs tátlelins, nē-tlōs túlínnac it-sleeps-then-will." "All right" The elder-one then stood-up, then took-it-she (answcred the old woman). (the cradle)

k*ilkwånac, nē-tlōs kēanăc, nē-tlōs mếtcakcec. Nē-tlōs placed-it-on-the-floor-she, then laid-the-baby-in-her-lap, then sat-it-up-she. Then

-kwấnac tē kốa, nē-tlō 'nklaúkwänac, nē-tlōs kép'enes tē took-she some water, then poured-it-into-the-basket, then "tonged"-she the

k'umpál'tca, nē-tlōs teípenac, nē-tlōs kwấnac tē kútla, nē-tlōs kítenac tē hot-stone, then heats-it-she, then took-it-she the stone, then lifted-it-she the

kútla, etl-caų́̊nac aitl. Nē-tlōs tcưnac tē cíckwōzea: "Nac kwām kō stone, then washes-it-she now. Then bids-she the younger-sister-her: "Go get a zōkwóz." Nē-tlōs nácite kwām kō zōkwóz. Qoāz k's-Híluic piece-of-punk-wood. Then went-she to get a piece-of-punk-wood. Not a-long-while nē-tlōs. tléEkcerc tē zōkwóza. Nē-tlōs wétckētec tē then returns-with-it-she the log-of-punk-wood. Then hands-it-to-she the cíckwōzca tē skūkumêta. Nē-tlōs Qomentcútec s'nītl aitl. Tē younger-sister-her the baby. Then hurries-herself-off-she (with) it now. The 
skílïmqa 'n-āqétcec. Teñk'u aitl, nē-tlōs lauwonEc, ne-tlōs elder one lays it(the wood)-down-in-the-cradle. Finished now, then suspends-it then Qētchétac tē kutLmémina tē cíla, nē-tlōs tcû́nac: "Qoīz-kwac-ōkwótcin hands-she the old-woman the string, then said-she: "Dont-you-touch-it (for swinging cradle)

jlan róit." Nē-tlō aitl ótskac nē-tlōs Qomentcūtec, p'zánac tẽ while it-slecps." Then now goes-out-she, then hurries-she-herself, overtakes-she the cíckwōzca, nē-tlōs kwấnac tē skukuméta skúkaiyūq. Nē-tlō aitl k•lkấk-ē younger-sister-her, then took-she the baby boy. Then now set-off-they mâtuk liakaúa; tcếoqwēt aitl tō kakaúa, tcéoqwēt aitl tē kakaúa, walking a-long-way; they-went now a long-way-off, they arrive now a long-way-off, máil-towèt tē tcítūQa, nē-tlō aitl cEwấ-ē. Nē-tlōs peténōsEm-ē Etl-stám-ac make-they a house, then now stay-there-they. Then ponder-they what-kind-of kálwet kōqom rēyep-stálī, kwāné-tac tē kálweta nētl aitl medicine quickly make-him (the baby) grow up, take-it-they the medieine then now wī-cauQEn-êtac, nētl kō-klō aitl Qốmec kw'e réEps; nē-tlō aitl léEltemp'c; washed-him-they, then thereupon now quickly he-grew-up; then now becomes-a man; nē-tlō aitl Ec-péakEn.

then now he-goes-hunting.

Nē-tlās-tō-kank’métca ē nanwâca yukīyáktca, klō-Hên-kõ kw'c Qōaic kwäc

1t-is-far-away-they-are those two women, a-long-time that not he was élal. Rap aitl, tē kutLmémena nē-tlōs tấtleliks tcăcänac erying Night now, the old-woman then stands-up she-felt-for-the-baby (the grandchild).

klō, zōkwóz. Nē-tlōs Qaaúnac tē kw'támitca: "Skwā-skwā—sEt
lo, a log.

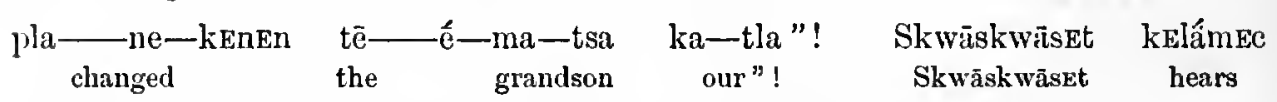

tlō-wic-ênwet kwa wEaú, nē-tlōs sấkEnEc tē 'nwópqEnca, nē-tlōs nekitcménac some-kind-of a noise, then pulls out a leg-hair-his, then puts-it-in-bis-mouth uē-tlōs écaunec, nē-tlōs p'têEkwuncec ḱtē tōi réqup. Nē-tlōs teuk's, nē-tlōs then he chews-it, then he spits-it-out into that water-fall. Then it stops, then móta kelánec etl-liñném aitl llō-wicếnwet cimám'ca, kaném aitl, nē-tlōs again he listens if-hear now it-might-be-the-sound-of wife-his he-hears now, then zōwấtEucc aitl. Nē-tlōs kētlélinc, tcéoq aitl tē tcítūQca, nē-tlōs he-understands now. Then he-starts-off, he-arrivest-at now the house-his, then skwálmin cimăm'ca: “nâkenem tē ématc-kátla zōkwóz." Skwāskwāset nē-tlōs she-tells wife-his: "changed the graudson-our log-of-punk. Skwāskwāset then teûnac cimám’ea: "Kảnemc Oōaic kwấcū áma kwácū cEátsuqc tē ématc-kátla" ? chirles wife-his: "Why not you better you look-after the grandson our.

"Hōimatl-záq̨Entetómen." ZấqEneEc aitl nē-tlōs nüc-ē; tcéoqwēt aitl

"Now-you-must-" pack'-me." He-packs-her now then go-they; get they now (said old woman) 
kōâlseka; nē-tlōs êtlum’c teE yáketca: "Pî́ma, ríma, ríma, ríma, outside; then sings-she this woman: "Shorten, shorten, shorten, shorten, n'ématc." Nē-tlōs rímalinc, kanémences tē ématc-êha kếta my grandson." Then the-path-is-shortened, hear-him-they the grandson-their at.little

tlas élals. Nē-tlōs kêtcīnac cimám'ca; nē-tlōs k eétlēle uk'u Ecwấca kwa distance crying. Then he-throws-her-off wife-his; then runs-he to where-is the élals. Tcî́qulmin kō klō, nē- - tlōs mốtac kaúaline tecaís-kō élal kō kakaúa crying. He-is-almost-there, then again it-goes-far-off a receding cry far far away. Skwāskwāsttkelêl aitl; p'ânet aitl tlếEkmēnac cimăm'ca, nē-tlōs tû́kEnac Skwāskwāset angry now; returning now he went to her wife-his, then took he

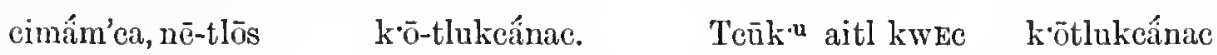
wife-his, then he-jammed-her-nose-into-a-log. Finished now when jamming-nose-into-log cimåm’ca Etl-tcứnac aitl: “Etl-rếe-kauq-matl tsúkwa, skwâtcītcū kōauit-kitl wife-his then said-he now : "Become-you tsúkwa-plant, name-your hereafter

óqwelmīuq, tsúliwa kitl kwā snăhentcêhacwèt, wa-kitl tzâkwan-tcêhacwèt." people tsukwa shall they-call-you, it-shall-be eat-you-they."

Skwàskwāset óqwel aitl, tcếoq tẹ tcītūQca nē-tlōs wấac." KlếEk aitl Skwāskwāset goes-home now, arrives-at the house-his, then stays-there. Comes now tce skó́zaca; nē-tlōs skwálnac. "Nē-ckózacūwa Ec-nắk u-tō uEnấnwao the danghter-his; then he-informs-her. "Child-you has-been-stolen-by two cyukĩyấktca." “'Nkấtōzam nē-tcipalếnca”? "Untoō. "Āma." Nē-tlōs women." "Where-is-now cradle-his"? "Over-there." "All-right." Then kwánac, nē-tlōs kêtcinac, nē-tlōs kwânac tē qEláka, nē-tlōs nảicite she-gets-it, then she-puts-it-down, then she takes the water-basket, then she fetches 'nzaúōm. "Nkấ-tō nē-kutla”? “Untoô." "Nkấ-tõ nēe-ncańqEmic"? water. "Where the-heating-stone"? "Over-there." "Where the wash-tub"? "Untoố." “'Nkấ-tō nē-kwisqténa” ? "Untoó." 'Nklaúkwänac aitl tē "Over-there." "Where the-tongs"? "Over-there." She pours in water now the 'ncaúǫminca; nē-tlōs tríkenac tē kwisqêna, k'épēnac tēe k'mmpálitca, nē-tlōs washing-utensil her; then she takes the tongs, seizes the heating-stone, then

pótlōnac tẽ 'ncaúǫeminca; kwấnac aitl Entcáktenca, nē-tlōs mốlōnac, nē-tlōs heats the washing-utensil-her; she-takes now the-napkin-her, then soaks it, then

k'lôpōnac, nē-tlōs wớquac, nē-tlōs élals, nē-tlōs túkEnac skūkumêta, nē-tlōs she wrings-it, then it-drips, then it cries, then she takes up a child, theu

caúqenac skúkaiyuq, nē-tlōs nEaqêtcec, nē-tlōs laúwanac, nē-tlō aitl she washes the-baby-boy, then she cradles-him, then she-hangs-it-up, then now eE-âmac kwācéc-atsuqcec. Nē-tlō aitl lélítumpe. Nē-tlō aitl it-is-well cared-for-and-looked-after. Then now he-becomes-a-youth. Then now

wấcitc péEkEm; tcếoq pếkEm; klếEk ốqwel. P'cil nac môta he goes ont hunting; he has been hunting; comes houne. Next-morning he goes again péEkEm; âlsuqEnac tlō mốta; klếkk óqwel, skúmsatl skwätcitca. Skwálnac: to hunt; he-saw-him again; comes home, napkin-man name-his. He told 
aitl tc' skếqözaca: “p'zantlkan-tlo mốta." “O n'ckóza nauk'-ménem-tō

now mother-his :

"Iē-kâteikeúwa,

the elder-brother-your

nē-kấtcikcúwa,

the elder-brother-your "met-I-him again.

Enán'wic cyukīyáktea two women
"O my son he was-stolen

nē-nank'-mén-tali-ha-tō

they-stole-him-away-a-long-time-ago nē-kấtcikcúwa Esmemetcáz; nn tĩ kōzâpilca tē the elder-brother-your has-a-mole; on the cheek-lis the sinEmeteấzca." P'cīl-móta nac mốta pékekm nētl aitl nesQếnae; mole-his." The morning-following he goes again hunting it is now he-seeks-him; kãnếmcEc tẽ wāamEếminem skwiläten, nē-tlō aitl nïe-mếnac, nē-tlōs he-hears-it the tapping-noise-of the wood-pecker, then now he-goes-towards-lin, then tećoq-mēn-ac; nẽ-tlōs mêtcak-ē; nē-tlōs skwālútec Skúmsatl. Nē-tlōs tcúnac: lie-gets-to-him, then sit-dowu-they, then spoke Napkin-man. Then said-he: Snúwa-ka kwEn-kătcik, nauk-mēnem-kō-tō kwen-kătcik "You-must-be my-missing elder-brother, he-was-stolen-by my-missing-elder-brother Enánūwac-kō-c̄ nauk'-mēn-talī-ha, auk·Eó tō-Etl-tlakstốmac." “Wonaúq two-women-they stole-him-long-ago over-there when-they-took-him-away." "True cEéntcEin. Nấc-kauq-tlō óqwel, tceáckau tlō móta nấtūe; nẳc-kan ớqwel, I-ambe. Go-you home, return-here again to-morrow; go-I home,

klēek-kan kitl tlō móta Etcấ etlkan-rípaca nâtūe; suúwa kléek-kauq etcỉ coune-I will again here when-it-is-noon-of to-morrow; you come-you here nátūq nētl kitl tlō Ens-näe éūwa Ecnúwa." Ớqwel aitl tē päpela, to-morrow then will I-go along with you." Went-home now the one, óqwel móta tē pápela. Ōqwel-wēt aitl. Tcéoq Étī tcítū qua móta tē went home also the other. Went-home-they now. He went to the house-his again the tce lílina, óqqwel aitl, klēek aitl Étī tcítūoca, skwál’nac skēqōzaca: younger-one, he reaches home now, he enters now the house-his, he tells mother-his:

"Wonariq nētl skốzacū nē-wā-íttsuqen-En, wâ-tcūntcas. "True it is son-your (that) I-Lave-been-in-the-habit-of-meeting, he-bade-me

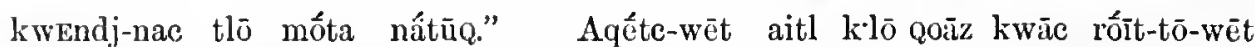
that-I-go there again to-morrow." They-go-to-bed now but not able to sleep-they.

P'cīl aitl, nē-tlōs métcake, nē-tlōs hớzac, tcūk's hớzac; nē-tlō aitl Morning now, then he-gets-up, then makes-ready, finished making-ready; then now nứcite, nế-tlōs tcíoqac En-swā-ēha-tō ê-nấtūQac; nē-tlōs âtsuqEmps etEó, he-sets-out, then he-went to-where-far-off yesterday; then he looks over-there,

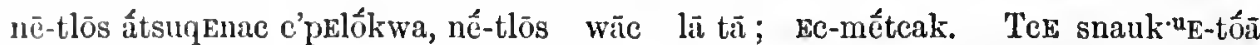
then he-sees smoke, then he stays there; he-sits-down. The stolen-youth tcếoq Étī teítūǫca nē-tlōs āqétcece nē-tlōs p'ténōeEm auk went to the house-his then he-throws-himself-on, then he ponders upon what his bed

Etl-kácece è teEnaál'tca; nē-tlōs pónac auk utu-kácece kitl. Nê-tlō he-should-do-with the fanily-his; then determines upon what-do-he will. Then aitl nácite $\mathrm{k}$ ólem kō kwéauIr; pónac aitl ē kwéauHa, kwânac now he-goes-out looking for some pitch-wood; he tinds now much pitch-wood he-takes-it 
aitl, óqwel aitl, tcếoqcec aitl, suksúkenac; tcūk ${ }^{\cdot u}$ suksúkknac, now, he goes home now, he arrives with it now, he-splits-it-into he finished splitting, small-pieces;

nē-tlōs ótlūqeec, nē-tlōs kâkanac; tcūk•u kw'c qaílems then he takes it into the house, then he-dries-it-over-the-fire; finished when doing atī; nē-tlō aitl āqêtc, Qoāz tlō aitl rốitc. P’cílac nánatīe, this; then now he-lics-down, not now sleeeps-he. It is morning just daybreak, nē-tlōs métcakc, nē-tlōs kwānac tē skílämqa cimämic, nē-tlōs k'ménac, then he-gets-up, then takes-he the elder wife, then throws-her-on-ground, nē-tlōs mätuke nákeliHe s'tāintlálEm. QuítleEc tlō mótā tē teElílina then she-walks-off changed into a grizzly-bear. He serves likewise the younger cimấmamic, nákenac tlō mớta mếqatl. Tcūk'u kw'c qaitleEc átī $\overrightarrow{\mathrm{e}}$ wife, be changes-her also a black-bear. Finished when doing-to this the

e'mámam'ca, kwánac aitl ē-te'-mälitca, nē-tlōs pónac, nē-tlōs caúk ${ }^{\cdot u} \mathrm{Ec}$ wives-his, he takes now the children-his, then he blows, then fly-away

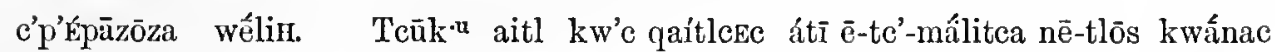
little birds becoming. Finished now when doing-to this the family-his then he takes

$\bar{e}$ kwéauha, rólnac. Nē-tlō aitl tcEäcitc, tlétuk aitl the pitch-wood, he burns-down-his-honse. Then now he-leaves, he comes now En-tcūwáca tē cickwốzca. Pốnac tē cickwốzca. ṓqwel-wēt where was-his the younger brother his. He finds the younger brother-his. Go-home-they aitl; tcếoq-wet tē tcítūq-êha, nē-tlōs wā-é En tī tcítūq-ếha. now; arrive-they the house-their, then stay-they in that house-their.

This is an extremely interesting and valuable text from a syntactical point of view. It gives us an excellent insight into the structure and idioms of the StlatlumH speech. The story is not a new one, but the StlatlumH version differs in many interesting particulars from that I collected from the Stseélis. It also rightly belongs here, being a Stlatlumir myth.

\section{English Equivalent of Above.}

Kaiyam lived in an écitken (a subterranean winter dwelling) all by herself. One night she had a peculial dream. Next day she went down to the water and sat upon the bank thinking of her dream. Presently she saw a soft-roed salmon, and recalling what had transpired in her dream, she set about enacting it over again. She took her knife and cut open the salmon, carefully taking out the long roe and washing it. She then transformed it into a child, teaching it how to cry. She then taught it to call her "grandmother." She then returned to the fish, and taking out the short roe, treated it in like manner. She now takes the two children, which are both girls, in her arms and carries them into her bouse. She is very happy in her possession of them. Thereafter she takes great care of them, and they soon grow to be big girls. When they are grown up, Kaiyam falls sick. 
She makes preparations for her death. She calls her two grand-daughters to her and tells thom she is about to die, and what they are to do for her when she is dead. "Put all my belongings with my body," said she, "my red paint, and my black paint, my stone hammer and my wedge, my spear and my basket, my paddle and my canoe, and also my fisher-head-band, and take me to yonder point, and place me and the things there. In four days I shall be dead." When the four days had gone by Kaiyam died. Her grand-daughters treat her as she had bidden them. They place her body in her canoe, and take it and all her other belongings to the spot she had designated. Then they left her and returned home. Then they weep and lament for her till bed-time. Next day they rose early. It was a lovely morning, and they went outside and sat down. As they sat they heard someone shonting. It was their erstwhile grand-dame, who had not really lied, but merely shammed death for purposes of her own; and she now appeared in the character of a man. The visitor called out, addressing the younger of the sisters, "Is it trne that your old grandmother Kaiyam is dead ?" "Yes, sir," she replies, "it is quite true; she died yesterday." The visitor now lands, hauls up his canoe and comes forward. One of the young women now enters the house and spreads a mat for the visitor to sit upon. He presently enters and sits down upon the mat. The elder sister now takes her water basket and goes out to fetch some water to cook the stranger a meal. She bids her sister get some firewood and make a fire, and heat the cooking stones. This she does, and the elder then propares a meal of roots. When it is ready they place it before their visitor, and he takes a spoon and begins to eat. Now, being really an old woman, the seeming young man had no teeth wherewith to masticate the roots, and as he had to hide his face with his arm while he ate, that the girls might not sce his vain efforts to chew the roots, he hell his blanket up to his mouth from time to time that he might spit them out. Presently he finished his meal and stands up. As he does so, the discarded roots fall to the ground. He now goes outside for a while. When he had gone the younger of the girls perceives the root he had spat ont, and, calling her sister's attention to them, asked her why he had not eaten them. "I don't know why," replied she. The old woman now decorates herself, putting on her mystie fisherskin head-band, and painting her face with the black and red paints, and parting and tying up hor hair like a man. She then returns to the young women. Erening arrives, and they prepare to retire for the night. The visitor shares the hed of the sisters, lying between them. He has intereourse with them, first with the elder, and afterwards with the younger. In order to effect this, Kaiyam had insed her pestle hammer as a genital organ. Next morning when they get up, and Kaiyam has gone outside, the younger woman says to the elder, "I am very much swollen in my genitals." The other replied, "So am I"; and their suspicions are aroused as to the genuineness of their new husband's manhood. The younger one seems to have suspected that some trick of their old grandmother Kaiyam was being played upon them, and she suggests taking measures on the following night to discover if their husband was what he seemed to be. "When 
midnight comes," said she, "let us tiekle him and make him open his mouth. I have notieed he always keeps his mouth shut when he laughs." The elder agreed, and the following night the two women set upon Kaiyam, and tickled her so vigorously that in the end she is obliged to open her mouth and ery for mercy. She prays them to stop, but they will not; and, being in danger of being tiekled to death, in self defence-she declares her identity, crying out, "Oh! leave me alone, don't tickle me any more; I am your grandmother Kaiyam." When they hear" this, instead of ceasing they continue to tiekle her the more, until she dies under their hands. The following morning the elder sister takes a rope and ties the olit woman's body up for burial. They then take the corpse down to Kaiyam's eanoe (which was really a big cooking tub, and not a canoe at all) and paddle off sone distanee upon the water with it. They then east the body into the water, and it sinks down and disappears for good, the air bubbles rising as it sinks. Then they return home again and make preparations for leaving the old place. When ready they start off, and in time get to the head of the ereek. There they perceive a house, which they enter. Within they find an ohl blind woman and a baby. The latter is in its cradle, which hangs from the swinging pole, and it is erying and sobbing. They go to see what is the matter with it. Said the elder, "It wants to be washed; tell the old woman to wash it." When the old woman is told what ails the ehild, she replies, "I am blind; I eannot see, to do it." "All right," said the elder of the young women, "I'll wash it for you and then it will go to sleep." "Very well, do so," replied the old woman. The young woman then took the eradle down, and began to make preparation for washing the child. She poured the water into the kettle, put the stones in the file to heat, and when they were hot, heated the water with them and washed the baby. As she did so she bade her sister go outside, and bring in a sinall punk lon. By the time the baby was washed the ycunger woman returned with the log of punk wood. The elder woman now gave the ehild to her sister, and bade her hurry away with it, and she would follow presently. The younger woman took the ehild and hurried off with it, and the elder took the pieee of punk wood anl placed it in the baby's eradle. She then hung the cradle up again to the spring pole, and, giving the swinging string to the old woman, bade her swing the baby if it eried. "It is asleep now, and you had better not disturb it; let it alone till it eries again." After this she leaves the old woman, and hurries off aftes her sister; whom she presently overtakes. They now travel on until they have left that part of the country far behind them. They then stop and build themselves a house, and remain there. They take great care of the ehilk, and search out and learn the best kind of medicine to give it to make it grow quiekly to manhood. When they discovered the right kind, they wash the ehild with it, and straightway he beeomes a man and takes the two women for his wives. He spends his time in hunting and wandering about the conntry.

In the meantime the old woman wlo liad been robbed of her grandehilel began to wonder as the hours went by why the baby did not wake np or cry. 
Presently growing anxions, she got up and felt for the cradle, and diseovered that where the baby onght to be was only a rotten log. She shonts out to her husband, who is down the creek some distance fishing, calling him by name and telling him that their graudchild had been changed to a log. The old man, whose name was Skwāskwāset, heard her shouts, but the noise of the water prevented him from understancling what she said. So he pulled out a hair from his leg, and after chewing it for a moment spat it into the waterfall. This caused the water to stop falling, and to become quite silent and still. He now listens to his wife's shouting, and understands what she says. He hurries home, and the old woman tells him what las happened. He scolds her for her carelessness, telling her she should have taken better care of their grandson. She replies by bidding him take her on his back, aud hurry with her after the thieves. He puts her on his back, and they set off in pursuit, and she, by her magic power and the repeated utterance of a mystic phrase, shortens the way, so that in a little while they draw near to the two women. They hear the crying of the baby a little way in advance. The old man now throws his wife off his shoulders, and rushes forward to catch the women; but no sooner is his old wife left behind, than the sound of the child's crying recedes farther and farther away, and soon he hears it no more, and knows not which direction to take. In anger he returns to his wife, and takes her up and jams her nose into a log, saying as he does so, "There! you shall become a Tsúkwa. By and bye people will eat you, and give you the name Tsúkwa." (The Tsúkwa is some kind of trailing plant or herb that grows on logs in the forest.) Skwäskwäset now returns home. After he had been home some little time, his daughter, the mother of the stolen child, returns, and is informed by him that her child has been stolen by two women. When she learns this, she asks him where the child's cradle was. Being told, she gets it and takes out the napkins. She now makes preparations for washing them, heating the water with hot stones, which she takes from the fire with tongs. When the water is ready she soaks the napkins and presently wrings them out. The drippings from the napkins are thereupou transformed into a child, which cries like a new-born baby. She takes this child and cares for him, and in a short time he becomes a young man. He now goes forth to hunt. One day, as he was out hunting, he saw a strange man, and wondered who he might be. On his return he told his mother, and she replies, "O Oh, my son, it may be your elder brother who was stolen by two women. You can easily find ont if it be he; your elder brother Thad a mole on his cheek." The following day the youth, whose name was "Squeezed. from-a-napkin," retumed to that part of the country where he had seen the suranger. l'resently he heard a tapping sound like that made by a woodpecker. He goes in the direction of the sonnd, and in a little while comes upon the stranger. They sit down together, and enter into conversation, and presently siqueezed-from-a-najkin says to the other, "I think you must be my missing brother who was stolen by two women." "It is true," the other answered; "I am he. Now I want you to go home, and come back here again to-morrow, and then I will go home with you." Thereupon they separate, the younger going home to 
tell his mother that the strange hunter was her lost son, and the elder going back to dispose of his wicked wives and the children they had borne him. Whicu Squeezed-from-a-napkin gets home lie tells his mother what has taken place, and that his brother had instructed him to return for him on the morrow. Both mother and son are so excited about the matter that they cannot sleep at all that night, and at the first break of day get up, the son making preparations for his journey, the mother for the home-coming of her first-born.

When Squeezed-from-a-napkin is ready he sets off, and in course of time reaching the spot where his elder brother was to meet him, sits down there to await him.

In the meantime his elder brother had returned to his house. As he lay abel that night he pondered over what steps he should take to punish his wives for their wickedness. At last he determined upon a course, and rises and goes out to gather a quantity of pitch-wood. Having found what he sought, he takes it home, and splits it into small pieces and puts it over the fire to dry. He goes back to his bed again, but is unable to sleep. At daybreak he rises again, and taking his elder. wife in his arms, he casts her upon the ground. Immediately she is changed to a grizzly bear. He then takes his younger wife and treats her in the same manner, only she is changed to a black bear. When he has accomplished this, he takes his children, and blowing upon them, transforms them into little birds, which now fly away. He then takes the pitchwood, and, making a fire, burns up lis house and all it contains, and then sets out to mect his brother. In due time they meet, and the two go home to their mother, and thercafter live with her.

\section{Tue Instructions of the Mountain-Goat People in Native Text.}

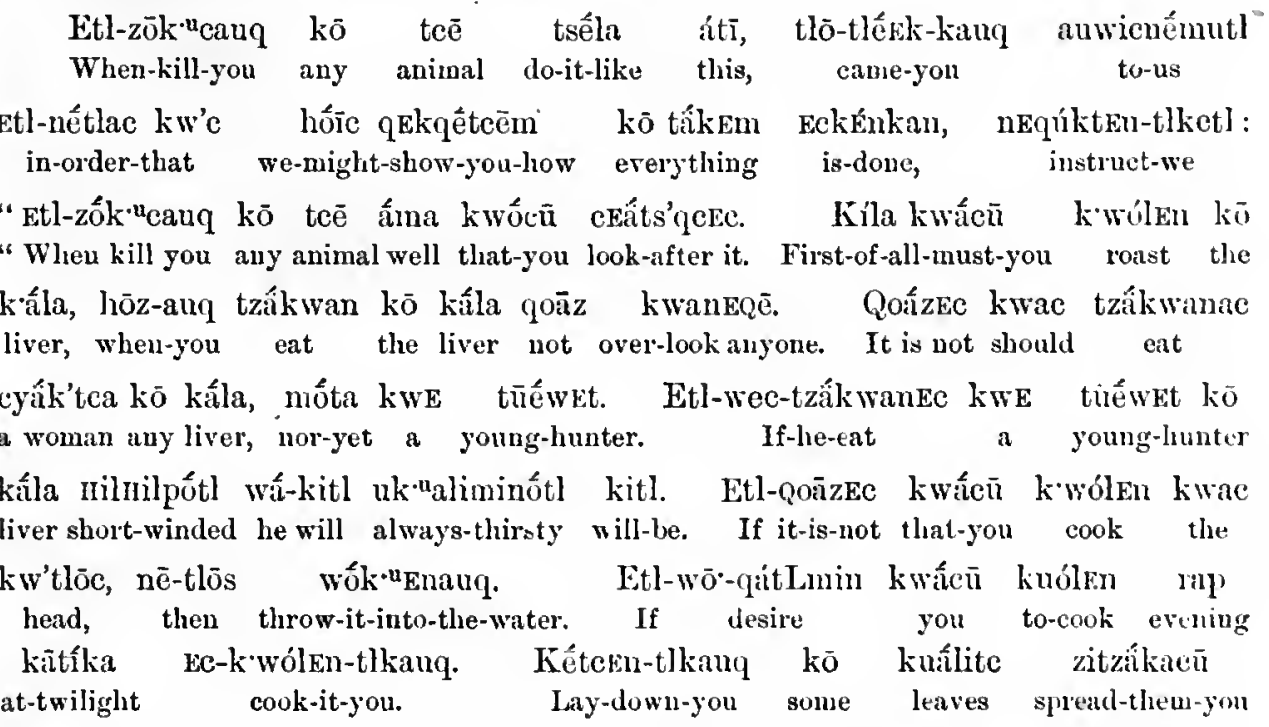
Etl-kêtcen-tlkauq aitl tec̄témōe ute pám'ca; metcốcrm-tlkauq En-ketecim; then put-it-down-you now facing towards the fire; mark-face-you across; 
pōtc-kwām-tlkauq auk' stếtlō. Teñk·ukw'c qētltcauq átī wetcócen-tlkanq. sprinkle-liead-you with down. Finished when doing-you this skin-head-you.

Kíla kw'c wétcen-auq tê zchōetca. Tcūk’u kw'c wetcócenauq tläk'éek‘at First of all skin-you the right-side. Finished skinning-head-you, short

k'wok'lócten-cū 'nqēek-ulukcán-tlkauq; rípen-tlkauq aitl. Kíla-tlkauq head-spit-you (take) thrust-it-through-you; stick-it-in-the-ground-you now. First-of-all-you the-nose

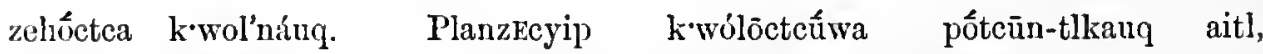
right-side roast-you. When-you begin, to-roast-face-you sprinkle-down-you, now, pōtc-kwám-tlkauq wicnúwa, meteócEm-tlkauq móta wicnúwa, Eck'útLuks-tlkauq "down"-head-you all-of-you paint face-you also all-of-you, mark-round-the-nose-you aitl kw'c nnetcōetcem-tlkauq aitl môta wicnúwa. 'Ntlāe hổīeu wetcócen tc' now mark-face you now also all-of-you. As-soon-as begin-you to skin the ki̛'tlóca nē-tlōs QEaíc kwakwaln̄t; 'n tlāe hối-cū k'wolóc tcūk•u tlō head then not any talking; aiter begun-you to roast head it is finished 'ntluk·upālōcec; Etl-p'élik aitl sk'wolóca tcaúwō-tlkauq aitl, when bur'sts-the-eye-ball; when-turnover now the roasting-head make-noise-you now, kwalñt-tlkauq aitl, nē-tlōs tcúwac neāsāwấyukstenc. 'Ntlāe hối-cu talk-you now, then their nEãsāwayukstenc. Before begin-you, kấqetltca kíla kw'c lauwan-auq, Ecketsálik-tlkauq, pótcūn-tlkauqu. drying-meat first-of all hang-up-you put-skewer-thro'-the- sprinkle-with-downheart-tongue-and-liver-you, it-you.

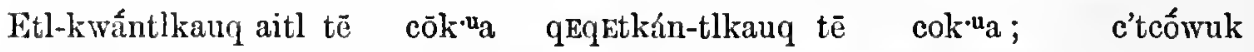
When take you now the upper-layers seore-it-you- the upper-layers; (then) the leg (of meat)

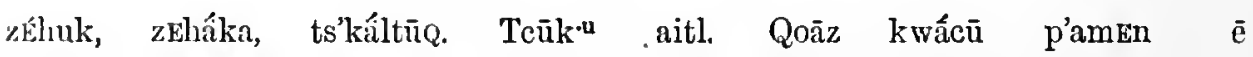
right, right arm, ribs. Finished now. Don't you burn-up the

mốliı-cúwa. Qoāz kwấcū Qấcōcmin kōk’tātl tlốec tcếtcil, kEl-wéliH meat-stretchers-your. Don't you grease-face-with fat when it-is-fresh, bad-become

kitl ē kw'tlócten-cúwa."

will the eyesight-your.

The English equivalent of this will be found in the myth of the origin of the mountain-goat kin given below. I thought it well to give this portion of the myth in the native text on account of its intrinsic importance, and because of its high syntactic value. It is of interest to mark the three different forms of the personal pronoun of the second person employed here, viz.: "-tl-kauq," the full primary copulative form,_- "auq," the secondary copulative form, and "cü " the possessive form. This latter is not a common usage. 
C'lamqEl.

Pruyer.

Kō-HEả kókpī, ckatza-tlkatl, âma tẩkEma óqwelmīuq kwāc Ec-ấtzaq Heavenly Lord, Father-our, good all people should take-care-uf tūwétac to'kwấtcitcūwa kíla âma. Áma ē-tấkema óqwelmīuq etl-teếoq̣ac everybody the name-thy most good. Good that every person if come-he óke e'nứwa kíla kókpī. Áma ē-tákema óqwelmīuq en teá teméceqa where thou-art highest chief. Good that every person in this world nōz-tcélac tūwétac tē teúwa s'wā skwälút hōz-teēlac ē-ốqwelníuq wa shall-do-like everyone-one the thy commands as-do all people who-are

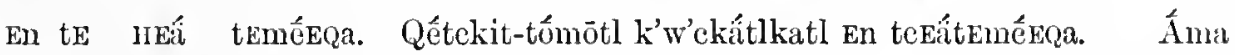
in the heavenly world. Give-to us some-food-our in this world. Good that tlápen-auq tē tcúwa tlkátla $\mathrm{kEl}$ wa-skōoóckin teéla teē tlápenEm tē kŕla forget-thou the thou our bad actions like as forget-we the evil wa-záiten-stốmōtl-ac ē céequtla óqqwelmīuq. Áma trelrel-stómōtl-auq kw'u done-to-us the other people. Good that make-strong-us-tliou that

qoāzaíc kwac kwấnem kō teếla kō kel. Ama eō-ceấtsuq-stốmōtl not take-we auy doing any evil. Good that there-is-care-taken-of-nis, kw'c qoāzale kwae katl kelkEnanteñt. Áma tcélac. in-order-not that we defile-ourselves. Good that it be so.

\section{Mytil of the Origin of the Mountain-Goat-Kin.}

Once, a long time ago, a young man, who was a mountain-goat hunter, went, forth by himself to hunt. Now both he and the other members of his tribe had been careless and inconsiderate in their manner of dressing their game and disposing of the blood and offal. This had displeased and grieved the chief of the mountain-goats, and he determined to have the young honter brought to lis eamp and instrueted in the proper way of killing and dressing lis game.

With this end in view, he instructed two of his young women to assume their goat forms and place themselves in the way of the hunter and draw him to the camp. Accordingly, when the youth was well into the mountuins, they show themselves to him under the guise of goats, and lead him in the direetion of their camp. After following them from eliff to cliff, he presently loses sight of them. He mounts the spur upon which he had last seen them, but instead of finding two goats there he sees two young women. Not perceiving that they were the goats he had been following changed to human form, he accosts them, asking if they had seen a pair of goats about there a few moments since. "I see," said he, "their tracks to this point, but can find no trace of them beyond." They smilc npon him, and say, "They are our own marks; we made them." Thereupon he falls into a trance, and the young women take him up and convey him to their eamp, which is close by. This camp lay beneath the water of a lake, which formed the roof of their 
dwelling. When they had descended with him, the young man recovers from his trance, and looks about him. He is surprised to see that he is in a fine large building, with a erystal-like roof over it. The inmates lie perceives are handsome, pleasant-looking people. He is soon made to feel at his ease, and the two young women who had brought him there are bestowed upon him freely as his wives.

$\mathrm{He}$ is not aware of the connection between these seeming people and the mountain-goats. Night now eoming on, all retire to rest. The hunter shares the bed of his wives, the elder lying on his right side, the younger on his left. At the first gleam of dawn two young men of the goat people leave their couch, don their goat-skin eoats and leave the camp. They had reeeived their instructions from the chief the night before as to what they were to do. Soon after their departure one of the young man's wives woke him up, and the other begged him to rise, and go out and shoot them some goats. He complies, and takes his bow and arrows and sets forth in quest of the game.

Now the two goat youths had been instrueted on this wise by their chief. "When our visitor goes forth to shoot, you must wateh him carefully, and see how he does it." When, therefore, they saw the young hunter approaching them, they waited and watehed him.

As soon as he pereeived the goats, he drew his bow and shot them. But as he wore his blanket, his arms and his bow were partly hidden beneath it, so that the two goats could not see distinetly how he manipulated his arrows. Said one to the other, "He put the arrow in his teeth." "No," replied the other, " you are mistaken ; he held it in his hand." When he had shot the two goats he returned to the camp and bade his wives tell some of the men to go and feteh in the game. Four of the men set off and bring in the two dead goats and skin and clean them. The young hunter observed how they did it, and pereeived the care and decornm they used in the operation. First they laid down many leaves with which to soak up the blood; when the cleaning was over these leaves were all carefully gathered up and carried with the other offal of the game, and east into the river. Next morning, early, the meat is cooked, and after the whole camp had partaken of it, the bones were all earefully gathered up and likewise thrown into the river. Everybody now goes into the water to bathe except the old men and widows, who stand on the bank and sing and dance and throw "medicine" into the water. Presently they return to eamp, and shortly after the hunter perceives two of the young men of the tribe come back alone, as if they had stayed longer in the water than the rest of the people.

He had missed these two youths the night before, and also that morning, and he wondered where they had been. The following morning he is again awakened by his wives and begged to go out and kill more game. He complies. Close by the eamp he perceived two yearling goats. These he brings down with his arrows, firing only one at each.

Now, as the two goat youths whom he had first shot could not agree as to the method of his shooting, the ehief had instrueted several of his people to keep watch close by when the young man next went forth to shoot. These hid in the 
bushes, and tried to observe how he eaused the arrow's flight, but the folds of his blanket again hid his aetions, and they also could not agree as to the manner of his shooting. On his return four men are sent ont to bring in the game. The same course is observed as before in eleaning and eutting up the goats. The blood is soaked up by the leaves, and this, with the rest of the offal, is cast into the lake. The meat is eooked and eaten as before, and the bones all gathered up and eeremoniously thrown into the water when they go to bathe. As before the old men and widows dance and sing on the bank and make "medicine." Again the young hunter misses two of the goat people, who presently come in a little while after the others. He wonders where they have been. Next morning one of the older men goes and stands just outside the smoke hole on the roof of the dwelling. The wives of the hunter wake him up and point out to him an old buck on this roof. He draws his blanket around him, seizes his bow and arrows, manipulates them under cover of his blanket, and shoots the old buek. His wives, who had this time been instrueted to observe how he shot his arrows, elosely watched his action, but failed, as did the others, to learn how the arrow was sped. Said one, "I saw him bite the arrow with his teeth." "No, he did not bite it," replied another; " he held it in his hand all the time." All the other inmates of the house were watching and whispering to one another. The arrow struck and killed the buck, which fell down through the smoke-hole. The earease is treated as before. Whilst they were eating its flesh, the young hunter notieed that one of the elders was missing. He closely watehes the others as they gather up the bones and take them to the lake, and notes that one of their number is still missing. He is also absent when they return to the eamp, but shortly after comes in with his face and head painted. The young man wonders where he has been, and begins to suspect that there must be some connection between the goats he kills and the individuals who go and eome so mysteriously. He determines to keep a close wateh and learn what this connection is. The next morning, when his wives wake him, he is not greatly surprised when they tell him that there is a goat in the house. He knows, too, that the people wish to find out how he shoots, so before he takes his bow and arrows, he throws his blanket round him, and speeds the arrow from beneath its folds. Everyone is keenly watching lis actions, but again they fail to learn how the arrow is sent. They dispute among themselves, one declaring that he put it in his mouth, another that he blew it, and others that he cast it with his fingers. They now get arrows and try to shoot with them, but all fail in the attempt, and henee, say the Indians, goat people and other animal people never shoot, as they do not know how to use the bow and arrow.

The following morning the hunter's attention is directed by his wives to a pair' of goats standing on a butte of the mountain some way off. He goes after and shoots and kills them, and this time he skins them limself. He also ents them $u p$ and cooks them after they are brought home. In doing so he surreptitiously abstraets a small bone from the base of the tongue of one of the goats, and a piece of the cartilage from the nose of the other. These he seeretes in his baek hair. 
After the meal the bones are all collected and taken down to the water as before. When the people return from their bathing and singing, the young man notices that two of them are still wissing. He now goes and lies down on his bed, holding the bone and cartilage in his hand. The two missing goat people presently return, and it is seen that something is the matter with them. In a little while his wives come to him and say: "Your brothers are sick; one cannot speak, and the nose of the other is bleeding; you have kept back some of the bones; please give them to us." He at first denies the charge. But they reply that they know he has them, and beg him to give them up. He now admits that he has them, saying: "I kept them to find out if you are realty people like myself. I know now that you are 'mystery' pcople. He now gives up the bone and cartilage, the former to his elder wife, the latter to the younger. They take them to the lake and cast them in. The two young goat people to whom they belong now dive into the water, and presently return well and healed. The youth had observed all, and now knew that the people he was living with were the "goat" people. He returns to the house and throws himself on his bed, and ponders upon what he had learnt.

Shortly after this he desires to lie with his elder wife. But she repulses him, and says, "Not so, this is not the time, wait till the next moon."

He then songht his younger wife, but she mide the same response. A few days later, the chief instructed two of the "kids" to go down to the river's edge.

Said he to them, "Go and sce if your uncle is chasing his wives." He referred to the " $\log$ " salmon, whose spawning season was just then coming on. The two young messengers go to a point or spur of the mountain overlooking the river, and make their observations, but see no sign yet of the salmon. They return and report accordingly.

The goat people therefore still keep camp.

After a few days more have gone by, other messengers are sent, and this time" they return with the report that the salmon are "lying down." By this time the moon was full, and the rutting scason of the goats come on.

The father-in-law of the young hunter now takes medicine, and eauses the rain to fall, and washes his son-in-law, and transforms him into a goat.

Next morning all the females scatter over the mountain, in their goat forms, and the nales play and butt each other, after the manner of goats in the rutting season. The wives of the young man had instructed their husband thus: "You (an chase and pair with any of the women now, and when the rutting season is over and we return, we shall be your wives again." The young hunter donned his goatstin, and, with the other male goats, set out to overtake the females. He outstrips all his fellows and "serves" the whole flock before they come up. The old bucks always stay at the camp. They lie down the whole time, never eating and never getting

1 This means that the salmon have spawned, and are dying and lying on the sand bars and banks. After spawning, a salmon frequently dies. The streams are full of dead salmon after s;awning time. 
up, exeept to evacuate, for the whole of the rutting period, which lasts from one full moon to another. A goat is considered an "old fellow" after his fourth year.

When the rutting season is over, a great rain is made, and all bathe and cleanse themselves, turn their goat skins about, and thus assume their human form again. They now remain quiet at the eamp, the males being weary and exhausted from the rutting and the females making preparations for their fortheoming "kids." When spring arrives, the women give birth to their children. The wives of the hunter bear him each a son.

He continues to live with the goat people all that summer, having lost all recollection of his former life and relations. But when the sumner is over and his children have begun to notice things, they ery incessantly for their paternal granclparents, ${ }^{1}$ and he now feels a strong desire to return to his old home. He grows moody, and lies for hours together on his bed withont speaking. His wives notice his behaviour, and know that he is longing to return to his parents. They therefore speak to him on this wise." "Cheer up, husband; we know you wish to go back to your own village and people. We will not keep you; you can take your two sons with you, but we must stay behind; we cannot aceompany you, we are not the same as you; the boys are of your bloorl, and so can go with yon, but we cannot." $\mathrm{He}$ is sorry to part from his wives, but his longing to return to lis old home is tow strong to be overeone, and he prepares to set out with his two boys.

When he is ready to start they bid him remember what he has seen and learnt among them, and to be careful in his treatment of the carcases of his game particularly those of the mountain-goat.

Said they: "Tell your people to paint their faces before they begin to skin anl cut up a goat, and to place the saered down upon the tongue, and lungs and heart, and hang the whole up to dry in the house over the fire, for that is gooc "medicine" for us. They must also carefully gather up the bones and other offal, and put them in the water, as you have seen us do. In cooking the meat, first ronst the liver on a spit, after putting down upon it; that is good "medicine" for us. When the liver is cooked take some fresh cypress branches, and place the liver upon them and cut it up into small bits and give a portion to each person. If you should make use of and cook the head, mark the face first with red paint, sprinkle down upon it, and place it before the fire nose foremost. Let it remain there a little while, and then skin it. The man who does this must paint his face and put down upon his head, and all who are near and watehing hin must be silent and make no noise of any kind. When the head is skinned, then place it before the fire again, carefully turning the right side first towards the flame. All the time the head is thus roasting, the people must keep silent; not even a cough or sneeze must be heard, or the "spirit" of the goat will be frightened away, and you would have no more luck in hunting goats. Let the head remain before the fire until the right eye bursts under the heat with a splutter, then turn the left side to the fire. Now the

In Indian stories this is a common way of reminding a man who has for some reason left his own parents and home and forgotten all about them, of their existence and his former life. 
"spirit" eannot see the people misbehave, and it does not matter if they talk and make a noise. If the "spirit" should ask the "eook" what that noise is, he ean answer, "That is your people's noise, not mine." When the head is eooked give a little of it to each of the elders; the women and young men must not toueh it. This must always be done at sunset on the day of killing."

The young man promised to remember and observe for the future all the instructions they had given him.

He now sets out for his old home, taking his two sons and the pack his wives had prepared, with him. When he gets near home he conceals himself and his sons on the edge of the village. Presently his younger brother came by. He was playing with a bow and arrow. He shot the arrow towards the spot where his elder brother lay lidden. The latter seized and held the arrow, and when the tormer eomes to get it, he is aecosted by his brother, and asked what he is looking for. He replies, "Ny arrow, whieh I shot in this direetion. Have yon seen it?" The elder brother now gives the younger the arrow, and tells him that he is his elder brother who was lost, and bids him go tell his parents that he has returned, and desire them to make the house elean and strew fresh branehes on the floor; for he could not enter till this was done. The boy runs home, and informs his pareuts that his elder brother was on the outskirts of the village, and desired them to elean and make ready the house for his reeption. His mother, who believes that her elder son must be dead, gets angry with him, thinking he is needlessly reminding her of her loss. She weeps and says, "Why do you tell me this lie?" and whips him and sends him ont of the house. The lad deelares it is no lie; but the mother refuses to believe him. He then returns to his elder brother and tells him what has taken place. The elder brother then unties one of his facks, and takes therefrom a choice piece of kidney-fat, and bids his younger hrother take that to his mother, and tell her again to prepare the house for him, that he was really eome home, and had brought two young sous with him. When the mother sees the fat, she knows her younger child's story must be true. She informs her husband, and then goes out to see her lost son. He tells her of his alventures, and all that had befallen him, and that his memory of her and his home had left him entirely for a whole year. When she has heard his story, she returns to the house and sends out her husband to bring in the paeks. Said she "Take your paeking-strap, and go and bring in our son's packs; he is really there." She then makes the house elean and tidy, and purifies it of all bad smells. This was neessary beeause her son had been living among the goat people, and, like them, would be harmed by bad smells. The goats had no fires in their houses and no smoke, and as they did not eat fish there was no bad smell of fish with them as with the Indian. When everything was ready, the young man and his two boys were brought home, and all the people of the village came to see him and them. He had brought with him four small packs. When everybody had eome in anl was seated, he took these four paeks, which eontained much more than they appeared to hold, being magrie paeks, and shook some of the contents of one of 
them before each of the visitors. One contained dried goat-1neat, one kidney-fat, and the other two goat-hair for making blankets. On the day of his arrival he distributed the meat only, and bade the people eome back again the next clay. The seeond day he opened the pack of fat, and distributed this in like manner; and on the sncceeding day, one of the paeks of hair. The fourth pack he gave to his mother. He had taken advantage of the presence of the people on these days, and had instructed them in the things he had learned, and how they ought to handle and prepare their.game, espeeially the eareases of the mountain-goats.

When this man's sons grew up, they became skilful goat-hunters, and never failed to bring home all the meat they neerled, the goats readily putting themselves in their way, that they might kill them and not lack food.

Paul gave me this myth in explanation of the origin of the mountain-goat kin of his father, who are supposed to be descendants of the goat youths.

I have given that part of it relating to the treatment of the dead game in the native text above, on account of its importanee and syntactie value.

I might add here, in this relation, that the liver of any animal was forbidden at all times to young people of both sexes-to young men, because it was supposer to make a hunter thirsty and broken-winded; and to young women, beeanse it made them short-winded when elimbing the mountain slopes in seareh of berries and roots. Even the elderly people ate sparingly of it because of its thirst-produeing tendeneies.

\section{Mytir of the Man who Restored the Dead.}

A eertain young man lived with his parents. Being of the age to marry, he took a wife, of whom he beeame very fond. They had not been married long when the young wife fell sick, and shortly after died. The corpse was wrapped in the best blanket, and put away after the manner of his people. The youth is heart-broken, and sorrows much. His uncle is sorry for him, and says: "Why not do as the old people advise and go for your kwāzănteūt (training for "mystery power"). He hearkens to his uncle's advice, and replies, "Very good, I will go." He eeased his lamentations, and went down to the stream, and washed the tears from his countenance. All his friends and kinsfolk are gathered at the house and make loud lamentations for the dead, but he joins with them no more. That night, when all the village is asleep, he takes his father's fire-drill and quiver of arrows, and starts off to undergo his kwäzánteint. He goes to the head of a distant creek, and then eonstructs for himself a 'nk·Élzaten or sweat-honse. Here he enters ujon a long eourse of bodily training. He remains at the creek for a whole year, at the end of which he has a vision, and a snam appears to him, and offers him the mystery power of curing coughs. This not being what he seeks, he betakes himself to another spot, and undergoes a second year's training. At the end of this period, he has a seeond vision, and the snam this time offers him the power of curing all pulmonary ailments. Again he is dissatisfied with his gift, and departs to another training ground. Here also he spent a year in exercises; at 
the close of which lye had a third vision. This time his snam offers him the power to eure miscarriages. "These," said he, "are not the powers I seek; I want to be able to restore $n 1 y$ dead wife to life." He seeks out a new spot and continues his kwāantent for another year. When the fourth year is completed he falls into a trance, and while in that condition learus from his snam how he may restore the clead to life. He is told to step over the dead body four times, and then it will rise up alive; nor need the body be whole, a small bone of it would do as well. When he recovered from his trance, he began to test his power. He sought for the bones of dead animals. He came upon one of the bones of a bird. He steps over this four times, as his snam had instructed him, and immediately the bone becomes a bird, and rises and flies away. He is now glad, and rejoices over his power, and seeks to test it still further. Presently he comes upon the bone of a deer. He treats this as he had the bone of the bird, and straightway a deer springs up alive and runs off. He is now anxious to test his power upon the remains of human bodies; he is not yet satisfied that he has the power to restore his wife to life. But he can find no human bones, so he determines to return one night when all the village is asleep to try his power upon the corpse of his wife. In the meantime he continues to practice and strengthen his power upon the bones of birds and animals. He learns to vary his practice. Sonetines he brushes the bones with the tips of fir-trees; sometimes he sucks up water into his moutl, and blows it ont upon the bones through his hands; and at others he blows his breath upon the object. When he thought he had grown "strong" enongh, he sets his fuce homewards, now to try his power upon his wife's corpse. Ho arrives at night, and opens the grave and levels the soil. He then steps over the corpse; it the first step his wife revived and sat up. He now brushes her on back and front and on both sides with fir-tops, then sprinkles "medicine water" upon her, and bids her arise. She stands up. He now invites her to eome with him to the stream. They enter the water together, and he washes her all over with fir-branches. This is to take away the odour of the dead from her. He now gives her a fresh, elean blanket, and then slowly and gently takes her home to the house of her parents, as she is still weak. 'They enter without disturbing the family, and retire to bed. The next morning when his mother-in-law rises, she perceives the couple at once. She wonders who they are, and quietly wakes her husband and whispers to him to look at the strangers in their danghter's bed. He looks and wonders also who they are, but does not go near them. Presently he rises, and noisily makes up the fire. The disturbance arouses the young man, who now uneovers his face and looks about him. His father-in-law recognises him, and says to his wife, "He is your son-in-law." The young couple now get up. The girl's mother is much agitated, and trembles greatly. She feels them to see if they are really alive, and not ghosts. When she is satisfied that it is really they, she is much rejoiced, and makes known the glad tidings to all the kinsfolk and friends of the family. These now flock in to see the marvel, and all are astonished and filled with wonder at the oceurrence. 


\section{'Nkwink winkéin.}

The Gambler.

There was onee a man who spent all his time in gambling. At tines he won, but more often he lost One day he had worse luek than usual, and after he had lost all his property, he staked his wife and ehildren. He loses them also, and is left without a single belonging. He feels sack and miserable. Some old people tell hin he should go and visit the gambling man, who lives afar off in the mountains. This man was a Qa Qa, or mystery man.

The gambler determined to visit this person, and learn from him the mystery of gambling. He goes off into the forest, and begins a eourse of mystery training. He built himself a sweat-house, and took many sweat baths. At the end of a year he set out to find the Qa Qa man. In time he eame to a stream, on the other side of whieh he saw smoke rising. The strenm was deep and swift, and he ealled ont for someone to come and put him over; but no one stirred. He ealls again and yet again, but still no one answers his eall, or puts in an appearanee. He becomes angry; he is tired; he yawns. No sooner had he done so than some one immediately calls out, "Hello ! there; what do you want?" "I wish to cross over; bring a eanoe and take me aeross," he replied. Presently a man appears, and paddles across in a eanoe to him. He gets in and the man paddles back. When they reach the middle of the stream he stops and asks the gambler where he wants to go. "Do you wish to eross to 'NÉzenēQa?" "Yes," replied the gambler. "No, don't go there," said the ferryman; "go to 'Nkélnēoqa." "No, I don't want to go to 'Nkélnēoqa, take me to 'Nḱzenēoa." The ferrynan tries to persuade his passenger to go to the house of 'Nkélnệa, but the other refuses. Four times the ferryman tries to induee him to go to 'Nkśnēea, but the other is firm, and refuses to be taken in that direction. He is landed at a point where two trails diverge, one to the right and one to the left; the one leads to the dwelling of 'NÉzEneog, the other to that of 'NkElnecon. Now 'NÉzeneega was the mystery being of all that was lovely and beautiful in nature, and 'NkÉlnēea was the mystery being of all that is bad and ugly. The former presided over good and fair weather, the latter over dark and foul weather. The ferryman now asks the gambler whieh trail he will take, 'NézenēQa's or' 'NkÉlnēoa's? The latter replies, "NF́zenēQa's." "No, don't take that; take the other," urged the ferryman. But the gambler was not to be moved. Four times did the ferryman ask him which road he wished to take, and four times lie tried to advise him to take that which led to the home of the bad spirit.

When the trial was over the ferryman led the way along 'NÉzEnēoa trinil. Presently they come to a Skumel, and the ferryman puts his head down the smoke-hole and eries out, "Here is a man eome to see you." "All right," answers a voice from below, "let him remain on the roof; I'll eome up in a monent. Meantime you go and get some kálite (young fir shoots)." 'NÉzenęqa now climbs up the pole and joins the gambler on the roof. When the slave 
returns with the fir-tops, 'NÉznēQa brushes the gambler all over with them. When he has finished he says to his visitor, "Look at your badness which I have brushed out of you." The gambler looks on the ground and sees what looks like the scales of a fish. 'NezEnèga now bids the slave take up the "sheddings" and cast them into the river, and invites his visitor to enter the Skumel. They both descend. They sit down, the gambler being given the seat of honour on the right-hand side of his host. 'NÉzEnęga now sprinkles "medicine" upon his guest. Presently it is evening, and night comes on, and a large party of ghosts come to the Skumel to gamble (slikEmäiwc), bringing with them much property. This property consists of the things that were put with their bodies when they were buried. 'Nkzenēqa taking some of his "medicine," sprinkles it on the ghosts, and they all suddenly disappear, leaving their property behind them. This 'NEzEnēQa gives to his visitor. Four days and nights 'Nkwinkwinkếin stays with 'NÉzEnēQa, and each night the ghosts come to gamble, and are frightened away by his host's magic, and he gets all their property. After the fourth night, 'Néznèeqa says to him, "Now you have enough property, you shall go home again." Before he leaves he packs up all the ghost's property into four bundles, and by his magic so decreases the size and weight of these that the gambler is easily able to carry all four. Ho also at parting presents lim with his magic flying gambling bones. 'Nkwinkwinkéin in course of time reaches his old home. He is now a wealthy man, and determines to' be revenged upon his old gambling friend who had stripped him of his former possessions.

This man's name was Humanóntc. It is soon known that 'Nkwinkwinkéin has returned with much property. Humanóntc cluckles to himself when he hears of it, and already considers it as good as his own. He makcs an early call upon his old friend, and proposes a little gamble. 'Nkwinkwinkêin assents, with a show of indifference. The people soon gather round to watch the game. At tirst 'Nkwinkwinkéin allows his opponent to win, and as his property passes piece by piece over to the side of Humanóntc, his friends look sorry, and feel sad at his ill-hek. But he smiles all the time, and tells them it is all right, that he is nut beaten yet. When he las lost all but the last blankct, he takes the magic bones of 'NÉzEnéga, and they fly so quickly from one of his hands to the other that IIumanonte is unable to tell which hand contains the marked one, and so loses his wimings piece by piece and all the rest of his belongings till he has not even $n$ blanket to call his own.

$\Lambda$ few days later it enters his mind to go away and seek a Qa Qa man, as 'Nkwinkwinkéin lad done. He therefore sets out. In course of time he comes (1) the river which hedesires to cross. He sees smoke rising on the other side, and shouts out to attract the attention of those who might be camping or living there. But he meets with no response to his calls. He shouts again and again, till he is ingry and tired. Presently he opens his mouth and yawns. No sooner had he done so than a man appeared upon the other side, and asks him what he wants. IIumanonte asks to be taken across. The man gets into his canoe and paddles 
over to him. From this point the story is a repetition of the experience of 'Nkwinkwinkēin, with the differenee that Humanōnte chooses to go to 'Nkelnēqa's house, where he meets with his death, which brings the tale to a close.

\section{Myth of the Deserted Boy.}

A long time ago many people lived at Seaton Lake. The chief of the village had a son about ten years old. One day this boy, who was of a gluttonous disposition, went to a certain house and told the inmates that his father had sent him to borrow some cured salmon, some s'teák wum (dried berries), and some skámite (long carrot-like roots). The woman says, "All right," and gives him the food. Now the boy had lied to the woman; he had come at the promptings of his gluttony, not at the desire of his father. He takes the food into the bush by himself and eats the whole.

The next day he tries the same trick, going to another house, and asks this time for some oil, some nEmátlkwa (salmon-butter), and some stīipál (salmon-flour'). His requests are complied with, and he takes the food as before into the bush and devonrs it all himself. Again, the third day, he does the same, asking this time for some cōk. (dried meat). Finding this an easy way to fill his stomach, he goes again the fourth day, and asks for some equs (fat) for his parents. By this time the people begin to talk about the ehief begging food each lay, and the boy's aunt, hearing the gossip, suspects what has happened, and comes to the boy's parents and tells them, asking if their son is borrowing food with their knowledge and consent. Said she, "Your boy has been round to all the houses, borrowing food, and saying you had sent him." "No," said the chief, "I did not send him, I do not think it can be true." "Yes, it is," replied the boy's aunt; " you wateh him, and you'll soon find out it's true." This the chief determined to do, and aceordingly sends someone to watch the boy's movements through the day. 'The boy, not suspecting that his trick has been found out, goes again to one of the houses, and asks for more food. The person set to wateh him follows him to the bush, and then leaves him eating the food whilst he runs back and tells the boy's parents. They come out and observe him themselves, and when the ehief is convineed of the truth of the story, he goes round to each house and asks, "Has my son come to you borrowing food for me?" All reply in the affirmative. The chief is much annoyed, and very angry with his son, and determines to punish him most severely. He tells some of the older boys to take him across the mountain, and when they get him there to lose him, and leave him to shift for liunself.

The boys start off on their trip, with the ostensible object of getting a supply of good arrow-wood. When they get on the other side of the mountain range, they intentionally separate themselves from the ehief's son and hurry back and leave him there. The elders had been waiting for them in their eanoes at the edge of the lake. As soon as the boys arrive the canoes are turned lakewards and everybody leaves. 
The deserted boy is thus left on the far side of the lake, with no means of crossing it. Now, the land juts far out into the lake at one point, forming a promontory. When the canoes round this, one old woman lags behind, and as soon as she is hidden by the land from the others, she paddles back to the old camp. She then gathers some of the discarder cores of the roots they had been eating, and put them in the ashes of the camp fire to set them smouldering. She then put them in her bosom to await the coming of her grandson. In the meantime the deserted boy had missed his companions and was making his way buck to camp. When he reached the crown of the mountain, he saw lying before him the waters of the lake, and in the distance the receding canoes of his people. He realises then that he has been deserted. He cries, and rages, and kicks the mountain so hard that a portion of it slid down into the lake, the course of which may be scen to this day. Presently, when his grief and rage have subsided, he returus to the camp. When he gets there, he perceives a small basket on the ground. He kicks it ont of his way, saying, "Why did you not go with your owner?" The old woman, who was lying under the cover which sheltered her like the roof of a Skumel, now cried out, "My grandson, I am here." She now takes from her bosom the smouldering cores, and says, "Sce here, my grandson, we can get fire witl these ; don't be downhested, I will stay with you." She is glad, and rejoices that he has returned; he also is glad to find her, and stops his crying, and makes a fire and constructs a small dwelling for them. The old woman now bids him go look in the teêpon (cellars) of the camp to see if he could find any salmon bones or scraps. Now, some of the people wlien they paddled off had felt sorry for the deserted boy, and had left some scraps of food for him in their tcépon. These he now gathers up and takes back to his grandmother. When she receives them she says to him, "Don't forget where you found this food; some day you can repay those who left it for you."

They continue to live there at the camp. He makes traps and catehes a number of small animals. Amongst these was the magpie. They eat the flesh of them, and the old woman makes blankets of the skins. The boy's blanket (Erēeétsa) was composed wholly of magpie skins. The summer is now advaneing, and the weather is warm and fine. One day the boy put on his magpie-skin blanket, and went outside to sit in the sun. Presently the Sum-man came down to the boy, and said to hin, "I wish to have your magpie blanket. Let us change blankets. You take mine, and let me have yours. My cnãz (blanket) is a magic lanket. If you put a corner of it into the lake the trout will immediately swarn about the spot, and you can take them readily. And if you desire lots of fish you have ouly to dip it a little deeper and you will get all you want. If you wish to keep them you must preserve them by drying them. Thrust a switch throngh their gills and hang them thus up to dry in the sun or in the smoke of your fires."

They exchange blankets, and the Sun goes back again. The boy now desires to test his magic garnent, and so goes down to the edge of the lake and dips one 
cormer of it into the water. Immediately the spot is teeming with trout. He puts in his dip-net and takes a netful at the first dip. He leaves them on the bank and l'uns back to tell his grandmother of his good fortune. She comes down to the water's edge to see his catch. She is greatly delighted, and bids him catch more. He dips the corner of his magie shining blanket into the lake four times, and they take more fish than they know what to do with. They dry large quantities and store them away. When they have filled their own tcépōn the old woman tells him to take the rest and put them in those tcépoon in which he had found the salmon seraps and bones, but to put none in the other cellars. The boy does so.

Now one day one of the men of his father's village, whose name was Crow, flew over to the lad's camp. He sat on the branch of a trec and began to eroak. When the boy saw him he said, "What are you laughing about? Come in and get some food; you look hungry." Crow comes and takes the fish offered him. Says the boy as he gives him the fish, "Don't let any of the other people see them, only your children." Crow takes home the fish to his family. When the young Crows saw the string of trout their father brought with him, they began to cry out and nake a great noise to get some. This attraets the attention of the village, and some of the people come to see what all the noise is about. They saw Crow feeding his children with a string of dried trout. They wonder where he has procurell it, as food has been very short with them all for some time. Crow makes no communication to them, so they watch his movements. Four successive days dirl Crow fly across to the deserted boy's camp and bring back with him a string of dried trout on each occasion. One man begins to suspect where Crow gets his supplies.

He says to the others, "I have watched Crow's movements for four days. Each day he has flown across the lake in the direction of our old camp, where we left the chief's soll. Let us send some one over to-morrow to watch what takes place there." Accordingly on the morrow two men paddle across the lake to the camp of the deserted boy. When they were about a mile off shore they perceive a bright and shining object on the edge of the lake. They wonder what it ean be, and go on very quietly. When they get near they see that the glittering sheen which had caught their attention comes from the blanket of a youth who is sitting down like a grown-up person. They land, and presently recognise the boy, and say to hin, "We have come across to see you; your father has been feeling very unhappy about you. How are you getting on?" "Oh," replied he, "I am all right; we have plenty to eat over here. Come in and have some food; you look hungry." They enter the house, and the old woman prepares them a bountiful meal of trout. When they have eaten, they depart again to report to the others what they have seen, taking with them a present of a good supply of dried trout which the boy made them.

When they get back to the village they inform the chief that his son has become a $\mathrm{Qa} \mathrm{Qa}$ or mystery-man, and is living in plenty across the lake. "Let us go over there oursclves," said the chief. They go across. When they are getting 
ncar the camp the youth takes a stone and throws it into the water, saying as he did so, "Go back ; you cannot land yet."

No sooner had he done and said this than the eurrent carried the canoes a long way haek. Again and again as his father and his people approached he caused their canoes to be carried back, and it was not till the sun was about to set that he permitted them to land. This he did to show the people his power.

When the people had landed and gone to their houses, those who had felt sorry at the desertion of the boy, and had left him some scraps of food in their tcépōn, now reaped their reward. They found their cellars stocked with quantities of dried fish, but the cellars of the boy's father and uncles, and of those who had not been friendly disposed towards him, contained notling, and they had to go to bed hungry that night.

Next morning the youth rises early and goes down to the lake and dips in his magic blanket. The lake's edge is straightway filled with fish. He now calls all the people and bids them help themselves. He now becomes a great man among them.

\section{Mytil of tile Dead Woman who became a Bear.}

There was once a young man who was a lucky bear hunter. He had a wife. She fell sick and died. He wrapped the eorpse in a fine bear-skin blanket and laid it away in the grave-box. A day or two after some youths went down to the river to spear salmon. They passed near the grave-yard, and seeing the tracks of a bear, ran back to the village and told the bear hunter. He called his dogs, and went to follow up the traeks. They led him here and there, and finally brought him to the grave-box of his late wife. He looked in and saw the corpse apparently lying as he liad left it. Beyond this point he could find no tracks of the bear. Next day fresh traeks were seen. He followed these up to their starting point, which was the grave-box of his late wife. He looked in the box and beheld it was empty. He knew now that the tracks he had been following were those of his deceased wife, who had come to life again in the form of a bear.

\section{Mytil of tile Marrlage of Nortil Wind and Soutil Wind.}

In the far-off days, Cútick, the North Wind, came south and married Skäpite the South Wind, and took her back to lis northern home with lim. Her lot is not a happy one. She is unaccustomed to North Wind's mode of life. He lives in an ice-house without any fire. Skấpitc sits and shivers all day long with the cold, and is very miserable and unhappy. She longs for her brothers, of whom she had thrce. The eldest was named Qōalánūq. He was the Wind that bears the sleet. The second was called Kupkuptcilániq. He was the Spring Wind. The third was called Hauhaulanūi. Hc was the Wind of Mid-summer. In her longing for her brothers she calls out to then one after the other, addressing them by name, thus:

"O, Qōqalinūq nètl-kn zōk: O, QōQalánīq, I an dying." Four times she wails forth this plaint. 
QōQalánūq hears the wailing of his sister, and says to his brothers, "Listen to what our sister the South Wind is saying." They listen and hear. At first the eldest will not believe that his sister is in trouble and unhappy. While they are discussing the matter and considering what to do, they hear her wailing again. This time she ealls to her second brother. Four times they hear her cry:

"O Kupkuptcilánūq nētl-En zōk;, O Kupkuptcilánūq, I am dying."

Before they have decided again what to do they hear her cries again. This time they are addressed to her youngest brother.

"O Hauhaułánūq nētl-En r.ōk, O Hauhaulánūq, I am dying." Again it is repeated four times. Said one of them now to the others, "Let us go and see what is the matter with our sister. QōQaláninq must go first, because he is the eldest, and we wilł follow." Thus it was agreed, and Qōaalínūq thereupon sets forth to visit the Northland, the home of his sister's husband. When he arrives he finds her very ill and wretehed. She is sluwly perishing from the cold. He awaits his brothers. Next day Kupkuptcilán̄̄q arrives and the day following Hauhaulánū After the arrival of the latter, Cútick, the husband, is very uneasy and much alarmed for his safety. The warmth of the Sumner Wind's presence is deadly to him, and he feels faint and sick. Skápite, seeing his conctition, tries to shelter him from the influence of her youngest brother by standing between them.

The brothers now desire to take their sister away with them, but to this the husband objects. Hauhaułánūq now gets angry, and approaches Cútick, who is terribly distressed by his wrath. The youngest brother is for killing Cútick outright, but the eldest dissuades hin, saying, "It will not be good to kill the North Wind, for then it will always be hot." So Hauhaulinūq spares him, and they take their sister away with them.

Now, the woman had a baby. It was an ice-child, and she wanted to take it with her. This she did stealthily, unknown to her brothers. She bound the child to the back of one of her thighs, and thus hid it beneath her blanket. But as they journeyed the presence of this ice-child caused a chilly atmosphere to surround them. This was very disagreeable to Hauhaulánūq, hel' youngest brother, and he sought to learn its cause. Said he to her, "I wonder where this cold wind comes from. Do you know what it is?" But she denied any knowledge of it.

In a little while he complains again, and taking his sister's blanket in his hand, pulls it aside to see if she is carrying anything beneath it. He at once perceives her ice-baby. "Why do you carry that?" he asks. "You cannot take that home"; and with that he takes the child from her and casts it into the river. It floats away and presently melts, and they continue their journey to the Southland. Because the South Wind carried her ice-baby at the back of her thigh, this part of a woman's leg-so believe the Indians-has been cold ever since.

I may add here that I did not seek to colleet any myths from the upper Stlatlum, as I had learned from Mr. J. Teit that he had made a collection from this centre for Dr. F. Boas. These have not yet, I believe, been published; but they doubtless will be sooner or later. 


\section{VOCABULARY.}

Terms of Consanyuinity and Affinity.

$\left.\begin{array}{c}\text { great-great-great-grandfather } \\ , " \# \text { " } " \text { mother }\end{array}\right\}$ ókiuk·s.

$\left.\begin{array}{c}\text { great-great-grandfather } \\ , \quad " \text { mother }\end{array}\right\}$ tsópiyuk's.

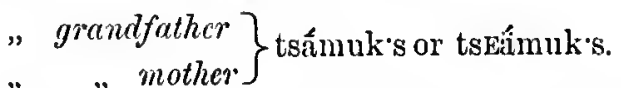

" " mothather, tcópa; my grandfather, n'-tcôpa.

grandmother, kốkwa; nıy grandmother, n'-kôkwa or n'-kwa.

grandson

granddanghter $\}$ ématc; my grandchild, n'-ématc.

grrandehile

grandchildren (coll.) Emếmate; my grandchildren, n'Emématc.

$\left.\begin{array}{l}\text { son } \\ \text { chaughter }\end{array}\right\}$ skốza; my son, tEn skóza; my daughter, tĩn skóza; my chilll, n'skóza. child

It will be noticed that the distinction between son and daughter is effected in this dialect by a change of the vowel. This is the only instance that I have detected of a formal gender in the Stlatlum speech, this division being wanting in those demonstrativo sex-denoting elements which $I$ have pointed out in the Halkōmélem, the Sk*qốmic, and the Síciatl tongues. And the way of making a distinetion between a son and a daughter in the Stlatlum is to modify the common term by coupling with it an abbreviated form of the terms for "man," "woman"; thus:-tēe skaíwa n'skóza, my "male" child: tē yákkutca n'skóza, my "femele" elild. The demonstrative particle, tē, which marks the presence of the object, is changed to nē, when the object under discussion is not present, ne being the particle which, in this dialect, marks the absenee of the object.

Children, stcumált or ctc'málit; my children, nE-stcumált. Speaking collectively of one's children and those of one's own brother or sister, the term is minkmEna, thus:-my ehildren, and nephews, and niees, ne mÉnEmEna. This is a reduplicated form of the common term for son, daughter, child, in the Halkómélem speech. When speaking of other children the terms commonly c'uployed are skīlimmét (singular) and skwumkókōmet (plural).

Mother, skéçoza, when spoken of ; when addressed kérya or kéHūya.

Fathcr, skittza, when spoken of; when addressed, kâtcya.

$\left.\begin{array}{l}\text { elder brother } \\ \text { elder male eousin }\end{array}\right\}$ kấtcilh.

$\left.\begin{array}{l}\text { elder sister } \\ \text { elder female cousin }\end{array}\right\} \mathrm{kEq} \mathrm{kEq}$.

younger brother

$\left." \begin{array}{ll} & \text { sister } \\ & \text { eousin }\end{array}\right\}$ cíckwäz. 
Note.-A man speaking of his sisters may use a common term withont reference to age; thus he may say, "nE céáktea," my sister, in answer to sueh a question as, "cwät teố?" who is that? The enquirer may then ask, your clder" sister? kEqkEqeüha? and if it is the younger he will reply No, "Qoñz," "'nteíckwãz," my younger sister.
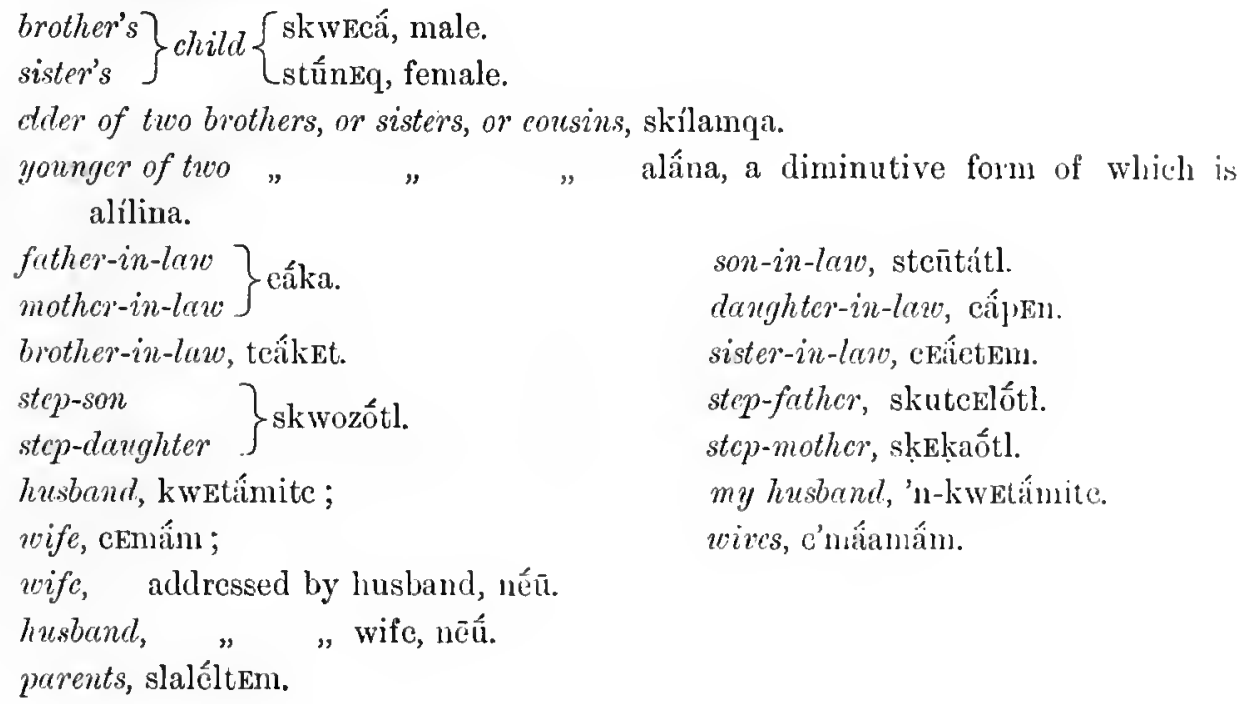

Brothers, sisters, and cousins address each other thus:cókwEI $\left\{\begin{array}{cc}\text { younger brother } \\ " & \text { sister } \\ " & \text { cousin }\end{array}\right\}$ addressed by clder brother, etc. äpa $\left\{\begin{array}{c}\text { elder brother } \\ \text { male cousin }\end{array}\right\}$ addressed by younger brother, etc. kíka $\left\{\begin{array}{c}\text { elder sistcr } \\ \text {, female consin }\end{array}\right\}$ addressed by younger bruther, ete.

It is interesting to compare these with the eorresponding Halkōmếlem terms which are all radically different. Thus:-

syik, clder brother or cousin, addressed by younger brother, sister, or cousin. Eyä, elder sister or cousin, addressed by younger brother, etc. $\left.\begin{array}{l}\text { Eyís, youngcr sister or cousin } \\ \text { Ey'ísuk, younger brother or cousin }\end{array}\right\}$ aldressed by elder brother, cte.

In this dialect each has a different form, but all are derived from a common root. 
20 C. Hill Tout.-Report on the Ethnology of the Stlathum of British Columbia.

Parts of the Bolly.

head, k’wómkEn.

face, skw'tlōc.

erown of had, natclekēn.

parting in hair, wākelakénten.

back of head, tceksapúken.

side of whole head, alána.

jav, kwEzózōqteEk.

liair (of head), máken.

beard, zliwópitc.

hair (on the body), kwāte.

tooth, raitemin.

sye tooth, kEqânic.

molar tecth, mótkānic.

tongue, tōqsátl.

palate, qaumin.

guems, tcēakánac.

nose, spózuks.

ear', k'léna $o r \cdot t$ léna.

eye, 'nk lōsten or 'nt lōsten.

eye-brow, nīwepkélōma.

eye-lash, tl'pấlic.

cheek, kōzâpel.

mouth, tcûtcin.

upper-lip, cÉatc.

lower-lip, skaúinetc.

throat, Hakazotlkwilt.

neck, nalâlēmet.

chest, täkwatc.

breasts, skām.

back, sqētskin.

stomach, óalēm.

arm, sqwōáqEn.

hand, skīákict.

elbou, käiqten.

finger, qōlāku, 'nhōlâke.

thumb, sk Elakwólāka.

leg, skwāqut.

knee, $\mathrm{k} \cdot$ 'paúicnen.

foot, s'pấanin.

bone, k'wókwōetl.

slin, cīpás.

blood, p'tíla.

liver, kấla.

fat, skwōkwetc.

tail, cúcpa.

rib, ts'kấltūq.

heart, cwâkuk or sqấkuk.

\section{Torms of the Principal Animals known to the Stlatium $\mathrm{H}$.}

Ucar (black), k'ōqwēEq, mêakatl.

"(brown), tcuk ulến mëakatl.

" (grizzly), 'stlätlálem.

beaver, s'kelan.

beavers, è s'kclaúa.

bee, skEiaznk:

lee (bumble), k•wuzkwuzáliq En.

butterfly (generic), päcít.

chip-munk, 'nk•ukquk, kwímqin.

congar, cw Ewóa.

erane, smók'wa, skwūlẹan.

erov', cấii.

decr, stlóla, or ctlóla.

dog, skịkạ. duek (gen.) sqaikk.

cagle (whitehead), spilkwakec.

eagle (black), yuq Elá.

elk, t'katc.

flea, klópezatc.

$f l y$, cuk·cícuk', n'māz.

frog, pāpétla.

goose, kwicéuq.

grasshopper, tlukatlúka (on a mat), so called because of the noise it makes when flying.

grasshopper, tcïntcen.

ground-h.og, cēEkcēEk (=whistler).

hawk, skuz. 
horse, Enketltcickákạa.

jay (blue), kewázaz.

kingfisher, tzuls.

lizard, nEkÉluqca.

oolican ("eandle fish"), swếwa.

otter, lehatz.

owl, skälúla.

pigeon, häméwuz.

rabbit, skwiéte.

rat, lấwint, Quz.

ravon, uíla, Hilaól.

robin, skwêkkuk, swêtek.

salmon (gen.) stzókwāz.

" (spring), skwúqEm.

" (sock-eye), laúwa.

" (eohoe), tcáwin. salmon (dog), kwáluq.

" (humpback), háloz.

" (stccl-hcad), kaíwaq.

swan, skupEméuq.

trout (gen.), zitzkwāz.

, (spotted), kwicpátl.

, (silver), stléukcutl.

wcasel (in summer), kumkíkunı.

" (in winter), t-Iukt lct luk.

wild cat, s'kutzámic.

wolf, skaúam.

wolverine, tc'kékEn.

woodpecker; ckwilúten.

" k'nēEk:

, tcókezuks.

aven, teetú.

\section{General Guossary of the Commoner Words.}

$a b l e, c a n$, qaitlite.

I am ablc, qaitlitc-kan.

above, teqā, túqa, tuḳa.

ache, pain, sore, kwälkwelt.

I am sore, kEn-kwälkwelt.

I am sore in the leg, kwäl-Hín-tlkan. across, $\mathrm{k} \cdot \mathrm{lāk}$.

go across, näc $\mathrm{k} \cdot \mathrm{lāk}$.

admire, to, kwámcin.

I admire, kwámcin-tlkan.

adopt, to, wonzyếpkel.

I vill adopt him, wonzyêpkEltlkan kEtl s'nitl.

advice, lúkaluq.

advise, to, tcūnámen.

I aulvise you, tcūnämen-tcé-tlkan.

adz, klämín.

afternoon, kEn múlakwa.

afternoon, (later ), rapÉlmin.

again, hū, mốta.

aid, help, to, nōk'an.

aim, to, tcôtlukcam.

air, breath, cūp.

alder-tree (alnus rubra), kwelólāz. all, tấkem.

alone, pepelätcút, from pấla, one, and tcūt (self).

always, pấpet.

anchor, nätcánäten.

anger, to, kElêil.

animal (gcneric), tcē.

another, hó́nkElta.

answer, to, aitcku.

anybody, tákema, täkEucwát.

apple, k'wEóp.

apple-trce, k'wEópāz.

approach, to, s'tlätlä.

$I$ approached the house, s'tliillittlkan tē tcítūQ.

arise, stand-up, to, tấtlì or tứtl'Elir. arouse, to, Qấkau.

$I$ arouscd him, Qâkan-tlkan-tō s'nītl. ashamed, ózōm.

I am ashamed, ózōm-tlkan.

$a s k$, to, caúwin.

I will ask, caúwin-tlkan kEtl. astonish, to, tekâk:

ashes, skwilátlkūp. 
210 C. Hill Tout.-Report on the Ethnology of the Stlatlumn of British Culumbia.

autumn, cóEz.

awl, sqaúwetl.

baelelor, kaíũmanict.

bad, kul.

bail, to, tlōkōwêtul.

brilcr (instrument), Entlökwëtlten.

bait, mämil.

bake, sk'wólem.

ball, mákup.

bark, to, wázam.

hc is barking, wā wăzam.

berk (of tree), tlák'wom.

busket, ts'lä.

beach, céqutc, or cúqatc.

beat, whip (to), cíkEn.

beautiful, kwämókmet.

born, to be, kEhấlha.

$b c d$, áqaitcten (thing to lie upon); Enrōiit-ten (sleeping-in-thing).

beg, to, qÉlentcam.

below, down, $\mathrm{k} \cdot \mathrm{l} \mathrm{Ep}$.

down stream, Enkókwitcha.

belt, zápwin.

liend, to, kótzun.

bent, Eskótz.

berry, skwel.

big, large, quzúm.

billow, wave, nilīuElēliн, snákuq.

bind, up, to, zócun, rútcin. (= to tie up).

lirch-tree, $\mathrm{k}$ wutlēnáz.

bird, spápazōza.

bite, to, klálen.

bittcr, tuq.

black, k'ōk•Qéeq, or k'ōqwéEq.

Wuckberry, skúlmoq, tcätcốca.

bianket (native), swókwatl.

blenket, lekwấz.

blind, s'nEmn Em.

I am Ulind, s'nemnEm-tl-kan (stateinent of fact form).

I ain bliml, kEn-Ec-s'nemnEm (responsive form in answer to question). blood, p'tila.

blow, to, pōn ; blow it ! pōnmatl!

blue, kwuzkwaz.

blush, to, tcäkóc.

boil, to, pótletl.

bore, to, eqútuk.

borer (instrument), quituk-min, or qútuktEn.

borrow, to, kótlen.

both (of us) n'anawoc-katl="two-we," ef. "all of us," katl-tâkkum.

bottle, 'n mékēl-ten (constructed from salmon-skin).

bottle, piipat (constructed from the sound of air-bladder of fish).

bottle, tc'mánik (constructed from the gut of an animal).

bottom, neî́tcuk.

bought, nctóqup.

bow, to, kwinócem, ad litt. (to turn the eyes earthwards).

bow, a, tóq Eatc.

bowels, guts, te'máuik.

bowl, 'nklaúkamin.

box, qútcim.

boy (little), tūúwit.

boy (youth), tūéwit.

boys, tūtūúwwit, tūtūêwit.

braid, to, skákïtla.

she is braiding, wā käkätlam.

branch, kemákict.

break, to (wood), kaúqūq.

" (rope), klélōq.

" (flat things), kīpúkwa.

" (round things), kācúka.

" (up, spoil, destroy), kulwéluq.

bridge, 'nk'läk'a min (thing that goes across).

bright, wrik·auk'um.

bring, to, cémac, tceúcec.

broken, split, Ecpuk.u.

bueket, water, qEláka.

brusl, k·lúamin. 
burn, to, k'w'tlip.

burnt, pámen.

bury, to, Eclep.

bush, kóqkwaōq.

button, áqauc.

buy, to, âz.

bye-and-bye, kuzawóna.

call, to, wEaú.

calm, quict, túkwup ; calm water, k’lókl.

camp, tcētworn.

camping-ground, 'ntcätcítūQ-ten, from tcītī $Q=$ (house).

can, Häitl or qaitl.

candle, torch, sight, c'tcak'u ; lantern, 'ntcauk'uten.

cunoe, k'lâz.

careful, tzōmënēleq.

I am carcful, tzōmēnēleq-kEn; he is careful, Ectzōmēnēleq.

carry, to (in hanel), stukac; I carry, stuk-tl-kan he carries, stukcec.

carry, to (on shouldcr), 'nk·c̄hék'mēn.

" (on back), zaq Endj; he carries

it, zaqEndjeec ( $c f$. c'zấqEn, a pack).

carry, to (ancler arm), 'nk.'mäqEnmēn. carry, to (on head), 'nk'ēläkénmēn.

carve, to, 'nteuxwálap. (This term is ap-

plied to the carving of crests and

totems.)

cast, throw, to, tzák'amīn.

cedar tree, tcấtäwoz.

ccdar-wood, ctsúka.

cellar, tcêpōen.

chair, scat, sk-ēlnk:

change, transform, to, nâken.

charcoal, sk'ozótcik.

chase, to, kâlnEm ; I chased him, kálen-

tl-kan-tō.

cheap, Eck'wốa, lêluk.

chcat, to, neēwoqzánac.

chew, to, ćcauwen ; cherv it! écauwenmátl.

chicf, kúkpī, or kwớkpì. chiefs, kwākwōkpī.

child, skukumèt.

children, skwumkūkōmèt.

choke, to (by extcrnal pressurc), lépatl-

kwetan.

choke, to (by swallowing), kEnhúkati-

kwelta, āk'anwêtl.

chop down, to (a trec), k'lútckam.

circle, Ezúnic.

clay, ckútlet.

clear (of water), lukaléEq.

" (of sky), Hốkōqkwem.

climb, to (a trec), $\mathrm{k} \cdot \mathrm{l}$ 'k·ēwilih.

" (a mountain), qấtlem.

closc, near, Ectlấ.

cloud, ckwốlel.

cold, ts'èp, Hutl.

comb, to, wèIItk'u-ten.

comb your hair! wēr'kwamtlkitlu!

come, to, klésk.

I am coming, klếek-tlkan.

companion, comradc, snúkwa.

compassion, pity, mósemētc.

corpse, cwilätlip, Eczōk:

cotton-wood-trec, nuk *u nék'wāz.

crab trec, k'weópāz.

cradle, tcipalén.

creek, stcūăwuq (large); steñówaq (small).

crooked, skōts.

cruel, hōnEkätla.

crush, to, pêtcin; crush in the hand,

lêpēn; with feet, kewáten.

$c r y$, to, élal.

cut, to, nékè̄n.

cut, $a$, Ecnék.

daily, tấkum Eckâit, zēzä Eckíitit.

damp, nónc.

dance, mốtsōm.

dancer, $a$, mōtsōmốtl.

dark, $\mathrm{k} \cdot$ lepetı.pem.

darling, dear, slukcéitl.

dawn, nánätūe. 
daylneak, Eck āitwélEı, tcitlpólmūq.

$d a y$, Eck'áit.

deaf', 'ntukwitkwína, tlúkwiua.

deceive, to, kík kza.

deceiver, a, kekezótl.

deep, 'nk'Epám.

deer hide, $\mathrm{k} \cdot$ Eütit.

desire, wish, to, cuatl, or cqatl.

$I$ want some water, auk ulmEn-tlkan wā n'chatl.

I want to drink, kenHatlmen kwendj wì ókwa.

devour, to, sâkwïnEm.

$I$ ate it up, sákwa-tl-kan-tō.

dew, chōk.

different, céąetl.

difficult, qätl.

đlig, to, áquel.

dim, kākwíckwicmä.

dine, to, 'nkumólukenam.

dirty, cket ·ket:

disappear, to, kehốmatūa.

diseover, to, pon.

I found out, póntlkan ; he found out, pónac.

dish (large), sláqutc.

"(small), tlítlqutc.

diver, a, 'nkumóluk Enamótl.

dizzy, encilikpóc.

door, 'nkéqutc-ten.

door-way, cípic.

dozon, stlétlau, or stlétlō.

drag, to, Qókwem.

drcam, to, kwilèkwilanq.

drop, to, kwic.

drown, to, wōk ${ }^{\cdot u}$; drown it! wốk ${ }^{\cdot u} \mathrm{En}-$ matl.

drum, (drawn skin), pūlấka.

" (uooden), kaurit.

euch, tē píla ; aul litt., " the one."

e̊rth, teméúq.

eusy, lếluk.

cat, to, k’ấ, sákiwan, or tzákwan. ceho, p’aúwitc.

eddy, zazílkwa.

elder-tree, kaigelp.

cnemy, umän.

enough, tcūk:

evening, rap.

fall, to, kwic.

famine, tâiit, or tEm täfit.

I am hunyry, täīt-kEn.

far, kakaú.

fasten, to, Erútcin (with rope); Ecrutc,

he's tiel it up.

fat (adj.), k'éqain; a fat person or

animal, k'wutck'wōtc.

fat, (soft), skwókwutc.

" (hard), k'utatl.

" (bear), 'skwōtc.

fear, to, päkwō.

I am afraid, päkwō-tlkan.

feather, ók'wel.

feel, to, tcácan.

$1 \mathrm{feel}$, tcấcan-tlkan.

fcrn, cïkópaza (Pteris aquilina).

fern-root, cáak, ", "

fight, to, k'léEkwentūwel.

file, zúk'amin, tsímelic.

fill, to, $\mathrm{k} \cdot \hat{o} \mathrm{l} \overline{\mathrm{n}}$.

find, to, pōn.

finish, to, tcúk $\cdot \mathbf{u}$.

fir (red), Ezyupól.

"(white), munétlep.

"(spruce), teáquz.

fire, cpämic, rólep, or wólep.

firewood, cpámic.

fire-place, 'npámic-ten.

fire-drill, cwótl.

fish, tcốkwāz (big fish); ts'Ekwāz (small fish).

fish, to, tcốkwāzäm (big fish) ; ts'k wìzam

(small fish).

fish-bone, s'teäm.

fishcrman, tcutcókwwazäm.

flame, rólep, or wólep. 
fht, teūî́lōmōq.

flcsh, slếuq.

float, to, päpuk'u.

flower, spák.Em.

fog, spótlit.

food, skï.

freeze, to, kếmälitc.

fresh, tcítcil (Thompson, teítci).

finyer, 'nlóläka.

gamble, to, tlikamańwac.

grmbling-stich, k'uk'óktl (bone).

ghost, spirit, cūqlítlip, cQūlátlip, mezâtc

(= breath or spirit of a shaman).

girl, cî́yaktea ; girls, cnkyćyuktea.

give, to, Qêtekit, or Qêtenèt.

glud, tcấuq.

glove, mitten, hếwiikii.

good, ăma.

goodl-bye, hốmātl, kEnâkĩ.

grass, elúlkem (long), etcúpuz (short).

great, large, quzóm.

greedy, Qōmite (from Qōm, quicli, and

ite, mouth.

green, kekwiliáa (used for yellow as well).

grind, to, 'nsukańcem.

grow, to, réy ep.

guillc, to, teūtliqấlem.

gum (pitch), kwälētl; pitch-urood, kwéoq.

hail, sk'uk'hốc (=tcars, eyedrops).

hard, k.éEq.

hav\%, listen, to, kālán.

hcar, to, kaném.

hemlock-tree, pōt-leināz.

iteh, wóteq.

jump, to, kaílir.

juniper-tree, púntlep.

keckwilee-house, cEécitkEn.

keep, to, weẩn.

kcttle (baskictry), 'nókwäten.

$" \quad($ wood $)$, steíma.

lind, good, áma. liss, to, 'ntlóktein.

lineud, to, zấken.

kneel, to, qētlélekam.

knife, QEēkten or wík Eten.

knock, to, 'npáteam.

know, to, zwíten.

ladder, 'ntlä́Eqten.

lake, tcälaitl.

lame, zồuk.

lanel, teméuq.

language, 'nkwälút-ten.

large, quzóm.

laugh, to, 'nk'cánik or 'nk'zanEk.

lazy, kèekElōtl.

leak, to, thlấuk; it's lealing, wa tláuk.

leaf, pite-ketl, (=it will drop ol fall).

leather, cêpáz.

leave, to, klélin.

lent, to, kwótlin.

liar, kekezótetl.

lie, to, kákiäza.

lice, mḱkin.

lick, to, sämáin.

lie down, to, áqaite, or áquètc.

life, máwel.

lift, to, qấtän.

light (both sunlight and moonlight tcitlip.

lightuing, k'welk·welkốcem (= "he (the thunder spirit) is opening his eyes").

line (celur withes), k'wôtsEm.

" (fishing line), êawecten.

" ("flat" or plaited line), k'Eçấl Eq-En.

little, small, kwếkwec (voice dwells on

" $\vec{e}$ " to mark the smallness of thing described).

liver, k’ála.

log, Eezếk.

logs, EezukEzêk.

long, záqet.

lose, to, pilip.

I lost it, pil'pitlian. 
214 C. HıL. Tout.-Report on the Ethnology of the Stluthem $\mathrm{H}$ of British Columbia.

louel, wonańqitc.

mun, skaúyüq.

men, skaiyukyñq.

maiden, k’álmōz.

maidens, k'lluk'ámōz.

make, to, mâicin.

maple-tree, k'Emlẫz.

muple-tree (vine), cêtstlip.

mark, to, smetc.

mesk, smák wī.

mut (slecping), släwén.

" (floor), tcíknin.

, (sitting), tcákuk.

meat, tcī.

medicine, kälwet.

melt, to, záauq.

midnight, téetoolwắc.

mid-day, keniripa.

mid-winter, 'ntếEthōeśken.

mind, 'nc'p'tếnōcin.

mine, enteúwa.

mistake, to, 'néquz.

mix, to, mát'lan.

moceasins, cêtltcō (from tcō=foot).

noon, k’'länämteus.

morning, nánätuQ.

mountain, EckwÉm.

move, to, zuikEn, cézk.

much, qōêt.

murder, to, sknāsákam.

murderer, a, sk:īsákinuótl.

nuked, tlótlok·u; he's naked, wā

tlótlok-u.

name, skwítcitc.

narrow, tétqa.

neur, setlí.

neculle, pátkwa.

net, spâtsin.

night, cétect.

no, ตุoñz.

none, qoãz káti.

not, qoiz.

now", aitl. nut (hazel), k’ápōq.

old (man), kutumén (plu.kutLkutı mên).

" (woman), kutLmimen.

orphan, wơwïicūt.

outside (house), ál'tseka.

pack, to earry, zấqen.

paddle, hómet.

pail (water), qälák k.

pain, to, tlíkwonEm.

paint, Qếkúsemin.

I paint, Qếkwèntlkan.

parents, slälëltem.

path, trail, Hwetl.

paw, spkíka (=fore paw), speúinyin

(=lind paw).

peel, to (bark), tlaúwelkwen.

" ( "with linife), oqwelkwem.

" (oncsclf, to undress), tlók wōntcūt.

peep, to (through a hole), 'nkElhälócem.

" (from brhind anything), zấk·ēl. penis, spúlok.

people, óqwelmūq.

perhaps, skánac.

plate, dish, tlítl'qutc, (small) tlä́qutc

(large).

play, to, cấicEz.

point, to, tcútlum.

poor, kElekenantcūt, kwúnkwïnt, mōzrmétantēit.

mick, to, têákain.

proud, cćakanc, Enskuzấm.

push, to, qéckin or rếkin.

put, lay doun, to, kêtcin.

quarrel, to, kwléil.

quiet, ckiip; talk quietly, ckäpitc.

race, contest, k'ultanwánaqa.

rain, ckwic (from kwīc, to dıop down).

raspberry (red), ceáitcuk.

" (red-cap), tlếkäk" ?

" (salmon-berry), tūwán.

recognise, to, cúqten.

raw, Ecqaíu. 
red, tcuk'tēēuk:

red-hot, k'umpákalite.

(stone), tcë̈kwálitc.

remember, to, käláqstōma, lukaláqic.

I remcmber, käläqtlkäna.

you " kï̈läqtlkauqa.

rest, to, zẩmEm.

I am resting, zấmEmtlkan.

return, to, p'ánet.

I return, p'ìn 't-tlkan.

revive, to, 'npēralúcem (=to sigh and

open the eyes).

reward, to, hâk' $\mathrm{En}$.

I will reward him, hak Entlkan kEtl snitl.

rib, te'káltõ.

ring, $a, \mathrm{k} \cdot \bar{e}$ ak'Enáka.

ripe (also cooked), k'wol.

river, cït'l.

roast, to (on a stick set in the ground inclining towards fire), skwól Em.

" (salmon cut open and placed over the fire), kúpEm.

" salinon not cut open and plaeed over the fire), ckítchen.

" (neat oves the fire), ckEpätltza.

" (salmon split open and held in the cleft of a stick), klîkca.

" (salmon, whole, by thrusting spit in its mouth), 'nqéwitc.

rob, to, näk'u.

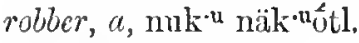

roof, s'k:āz.

root, klükwámflauq.

rope, line (plaited flat), k'utlïliqen.

rope (ccelar withes), k'wútcem.

rose (wild), kíluk.

round, Esk•úmōq (plural or several,

Esk'úmak'umōq).

$r u b$, to, mékwēn.

run, to, kétlēl.

I run, k'ćtlèl-tlkan. salt, ts'ul (=taste of fresh meat).

sall-water, k-ōt?l.

same, iike, tzultzēlaklō.

sand, sk'ầpa.

say, to, teūt.

scald, burn, kw'tlep.

scalp (salmon's), klelweók:

" (man's or animal's), cịpázōk•u, of.

cippát = skin.

scold, to, kelếlmēn.

screpe, to, patqan.

seratch, to, côpuñn.

scream, to, étlaqtcam.

sea, $\mathrm{k} \cdot \overline{\mathrm{ot}} \cdot \mathrm{l}$ or kwōt'l.

scarch, to, Qćlin, t'Qócmēn.

sced, clipHál.

sce, to, fitsqEm.

scize, to, k'aileHmēn-túkEn=" to jump-

take."

sell, to, taúwom.

send, to (person) kienán.

". (objcet) nacäkáum.

scw, to, k’lokōHál.

shadow, shade, menEmán.

" reflection, skukEnếwatl.

shake, to, t-lókìin.

shallow, 'nuqwêwecim.

shaman, cwonẩm, kwbékwilauq, zúwa,

zūwến, kwéchētum wa kwEếkwilauq. sharp (of calyed tools), Qúzouz.

" (pointed) tcímitsmulic.

sharpen, to, 'nzūk'ócen.

" (bring to a point), zuk'ukcan.

she, her, s'nītl.

shine, to, wok'aúEkum.

shoot, to, kwócim.

short, tlāk'ếEk'at.

shout, to, wEaú.

shove, to, kwếwin.

show, to, atsuqấletōmir.

shrinli, to, raíceleq.

shut, to, kéqtean.

sick, âlsEm. 
sichncss, sEîllsem.

sight, tühóc.

silfut, k-liketkum.

simple, ectsy (to get), léluk.

sing, to, k'létem.

$\operatorname{sink}$, to, 'nEmátec.

sit, to, mếteuk; sit dou'n! mêtenkmatl.

slin, cīpáz.

skull, k'ơnkEn.

sly, ctleEkut.

slop, to, t·luk:won.

slapping, thíkwitlk'won.

slête, cấwit, cíwwit.

slet $p$, to, rót.

slcepily, rōitúlmin.

slide, to, kwetQaílili.

" (of mountain), cEaniq.

slip, to, kwÉtuq.

" trip, to, kweoriyin (on the level),

kwétoquyin (on a slope).

slow, zôwōe.

smart, quicli, lúqeluq.

smell, to, cūmūn.

smoke, spilók (going up straight),

cmúken (spreading all about).

smother, to, lẹpiteî́n Em.

snail, k’laiâk'En.

snceze, to, hucnána.

" $a$, nicnäina.

snore, to, qōqwelukc.

snou, mákia ; it's snoring, wà mákì.

snou-shoe, tsōtsiyel, toōtsqel, or

teōtsq En.

soft (to the touch), k'upk'ap.

"casy (to break), quiquwam.

sold, taum.

solid, 'nkumpritltea.

some, mốta ; hōmóta = some morc.

song, ftlum.

soon, kiilál.

soot, skittlote.

sone, kwálekwilt.

sonp, ctlium. sour, t'zklt'zól, tuq = bitter.

sou, to, pókwel.

sparks, wólulik or rólulik.

spawn, nauwíwa.

speak, tell, to, kwälút.

spinal column, 'múqteik.

" cord, 'ntetlkílēpaten.

spinster, yuktcámanict.

spirit, soul, cmáwel.

spit, to, p'tếqwon.

spoon, ctlākémin.

spread, lay, or put lown, to, kétcen.

spring, släkâketliwa (= to bublle

up).

squecze, to, lép'èn.

squint, to, 'nkótsalōs.

stand, to, stïtlin or stiitlelilr.

star, 'nkakōs'net.

stare, to, sEattsuqce; he is staring, wa sátsuqcec.

steal, to, nauk 'u ; a thicf, nuknauk'otl.

step, to, céEquqEnEm.

stew, boil, to, tcéaqain (soup, ctlüm).

stick, to, tsúk $\cdot$ pan, tsúk Ep.

stink, to, Qōoóh.

stone, kÉtla or kítla.

stoop, to, tlákiōt.

stop, to, kák lèla.

straight, Eckwáp.

strange, fresh, tcitcil.

strap (head), mâkēin.

stream, c'tüaúq.

stretch, to, teícin.

strike, to, cíkEn.

string, cil.

strong (thing), k·ēuq (animal or person), rulrul.

stumble, to, k'wók'wēwäm.

stump, 'nk''wūs.

stutter, to, Ec'nitenate; he's a stutterer, wä Ec náknatcōtl or nētl ec nákenatcōtl.

suck, to (the brcast), kEŔm. 
suck, to (something in the mouth), tcơmōn.

" ( " held in the hand), klôkōn.

summer, tem kum'p.

sun, snúkwum or suńk um.

sun-bean, swáqets snuk'uma $=$ legrs of

the sun.

sun-risc, ótska snúk uma=outside the sun.

sun-sct, rap = evening.

sure, certain, wönaúqnūn.

surprise, astonishment, tnkák", ctukutc-

mēı.

I am astonished, tukäk tlkan.

swallow, to, k'uminc.

sweat, to, háan.

sweat, perspiration, cháau.

sweep, to,áqwelap, ef. broon, áluwelap-ten.

sweet, $\mathrm{k} \cdot \mathrm{l} \mathrm{Eq}$.

swell, to, pau.

swim, to, 'nkítiliri.

swing, to, papếla.

tail, cúcpa.

take, to, túkEn.

tale, swäl.

talk, to, kwā] út.

tall (said of persons), zấralkwum.

" long (of things), zákiyet.

tame, tcúktcük.

tastc, to, k’länamen.

tattler, hwīlūtótl.

teach, to, tcūnä́min.

$I$ will teach you, tcūnämin-tcētlkan-ketl.

tear, to, tcor'pan.

tcar (lacrima) 'nEkweúlōs, skúkhōs= drop (applied to hailstones). tell, to, skwāl.

I will tcll you, skwälen-tcē-tlkanketl.

that, teó.

thaw, to, teúweq (icc), tếEm (snow).

there, tūô. thick, p'tlūt].

thief (habitual), nuknaukótl.

thin, wếm'ca.

think, to, p'tênōeim.

this, tceí.

throw, to, ts'ak:

throw it away, ts'âkamēn kekaú.

thunder, ckílikaloq=knocking noise,

skinkEnap = tapping noise.

tickle, to, 'nEk'Ezánken, or make to Iangh. tic, to, rútcin.

tired, weary, kwelkwíl.

to-dlay, tl'kónca, sk·èt.

to-morrow, nätuQ.

tongs, kwisqÉna.

toothache, $\mathrm{k} \cdot$ innic.

torch, ctauk $\cdot$.

trail, inwïtl.

trop (weir), tcilmēn.

" (busket above weir), kwiltcáza.

" (" with distended mouth), 'ntcukautcến.

" ("fall" for small animals), tcếteilōe.

" ("fall" for big animals, bear, cte.), Hât $\bar{c} \mathrm{c}=$ heavy to lift.

$"$ (gcreric), kílkilten.

tree, cyap or crap.

tremble, to, t·litlt·litlnÉm.

trip, to, tlóqujke= to fall on the nose,

tlóqwupqEn = to catch one's foot.

turn, to, pelkócem.

turn over, to (of things), pélkan.

turn, to (by itself, without asrency), pelkéleq.

twilight, kekwäca.

twist, to, k'lōpíleq, Ectlóp = it's twisting

(stid of crack in splitting wood).

ugly, tziztyuzket.

uncover, open, to, wólkwan.

under, 'nk'lpánek, s'tlípca.

understand, zūwáten.

I unelcrstconl, zowíten-tlkan. 
218 C. Hill Tout.-Deport on the Ethnology of the Stlatlum $\mathrm{H}$ of British Columbia.

undress, to, tlókōtcūt, tlớk’'leq.

unfasten, undo, Ectéóh.

unripe, Ecqaíu.

varnish, to, kekcípa.

village, Ectcītūo.

roice, 'nkwioulút-ten.

romit, to, wấtlik:

$u$ adc, to, tcáitcwïm, tcíqwam = to take

a few steps into the water.

wait, to, kílkm.

wake, to, onk.

ucall, to, mátuk.

ucell, qúlten.

wander, to, metmámetuk.

wàr, kultōwaúq.

warm, k'úmep.

wart, zezóōk.

wush, to, tzáiriun, cauQ̨em (= to wash

oneself), wã cauQEm, he's washing

himself.

watch, to, Enêitcuqcac.

uater, kō or kwō.

wave, billow, nilı'likēlin.

we, $\iota s$, wicnémōtl, s'némōtl.

weak, kếkelel (said of persons).

" Qōaz kwac ruluul (=not strong; said of anything).

ucary, kwilkwál.

wearc, to, k'utcêtsa (blankets), kutckíil,

(bands, straps, etc.).

ueave, to (anything), Eckítc.

wedge, quiet ("Kaiyám's wedge," nè Qüétea kaiyam).

veep, ery, to, kuk'Qócam, ếlal; hc’s

crying, wà ćlal.

wcir, tcílnēen.

when, èkállnacac, (past), kánmacac

(future).

when (comlitional), Etl.

where? Enkía? 'nká? which? unká? nētl kō unká?

whisper, to, ckákapitc.

uhistle, to, Qíten.

white, puk:

who? cwät?

why ? wā-kănem ?

wide, ctl'k'álap.

vidow, eczáten.

widower, "

wife, cimáin, nêu (when addressed by

husband).

willow-trce, t'qấtlpâz.

win, to, tlōgöm.

winner, t·lōęomótl.

wind, ckúyEm.

wing, stlakál.

wink, to, klōtsālócem.

winter, tEm qutl ("cold time") tEm

ctótik ("cold-wind time").

wipe, to, ápan.

wise, lúqaluq.

witch, zówa or zû́wa, cwenáam.

with, êuwa.

I will go with you, nackan cūwa Ecnúwa.

uoman, cyăketca.

women, cyukeyâktea.

wood (gen.), múlin.

wool (gen.), kwätc.

wring, to, k*lópūn.

yawn, to, Echáū.

year, Qutpäzinōe = completing the circle.

last year, ēzánōe'mac.

next " zấnōQum-ketl.

yell, to, étluqtcam.

ycllow, kuk' 'léä or kukwiléä.

yes, $\overline{\mathrm{e}}$.

yesterday, ènátū@ac.

you, wicnúlap, s'núlap.

[Reprinted from the Journal of the Anthropological Institute, Fol. XXXV, January-June, 1905.] 

